\title{
THE REVOLUTIONARY WAR AND THE MILITARY POLICY OF THE UNITED STATES
}

FRANCIS VINTON GREENE MAJOR GENERAL, U.S.V. 


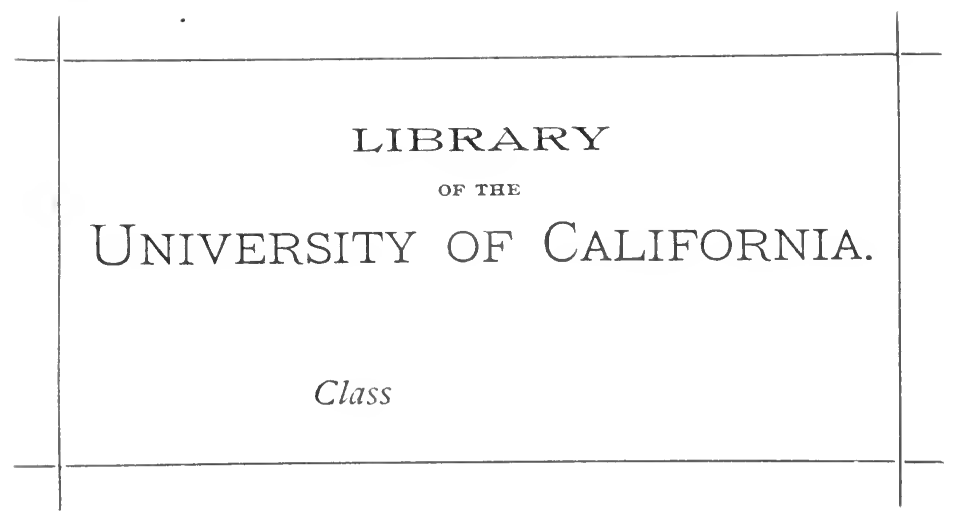




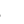


.

. 


\section{THE REVOLUTIONARY IVAR}

AND THE

MILITARY POLICY OF THE UNITED STATES 



\section{THE \\ REVOLUTIONARY WAR \\ AND THE}

\section{MILITARY POLICY OF THE UNITED STATES}

BY

\section{FRANCIS VINTON GREENE}

GRADUATE OF THE U. B. MILITARY ACADEMY

MAJOR-GENERAL OF VOLUNTEERS IN THE WAR WITH SPAIN

\section{AUTHOR OF}

The Russian Army and Its Campaigns in Turkey in 1877-78 (1879). Army Life in Russia (1880). Improvements in the Art of War (1882). The

Mississippi Campaigns of the Civil War (1883). General

Greene : Great Commanders Series (1885).

The United States Army (1901)

NEW YORK

CHARLES SCRIBNER'S SONS 


\section{$E 25 !$ $G^{?}$}

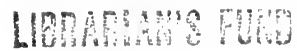

Copyright, 1911, B Y CHARLES SCRIBNER'S SONS

Published May, 1911

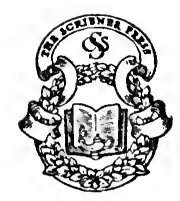


TO THE

OFFICERS AND MEN

THOSE NOW LUING AND THOSE WHO haVe GONE BEFOBA

OF THE

UNITED STATES ARMT

WHO HAVE

CARRIED ITS COLORS TO VICTORY

ON MANY FIELDS AND IN MANY CLMES

HAVE COMPELLED THE GURRENDER OF ITB ARMED FOEB

AT

SARATOGA AND YORKTOWN

VERA CRUZ AND THE CITX OF MEXICO

DONELSON, VICKSBURG, APPOMATTOX AND DURHAM'S STAT:ON

SANTIAGO AND MANILA

AND WHO

IN THE INTERVENING YEARS OF PEACE

HAVE

SUBDUED THE SAVAGE

EXPLORED THE WILDERNESB

PREPARED THE GREAT WEST FOR THE

TEEMING MILLIONS WHO NOW INHABIT IT

CONTRIBUTED TO THE ADVANCEMENT OF BCIENCE

ABATED THE TROPICAL PESTILENCE

DIRECTED THE NATION'S PUBLIC WORKS

conetructed the panama canal

THIS BOOK

Is

WITI FROFOUND ADMIRATION AND WARM-HEARTED AFFECTION

RESPECTFULLY DEDICATED 
. 


\section{PREFACE}

The purpose of the book of which this is the first volume is to present, within the limited space of three small volumes, the essential facts in our military history, and to make such analyses of these facts and such comments upon them as may be useful for the future and interesting for the present.

The army has always been a factor of prime importance in our national life. It was due to the skill of Washington at Trenton and Yorktown, and the fortitude of his officers and men at Valley Forge and elsewhere during eight long years, that the labors of Samuel and John Adams, Patrick Henry and Thomas Jefferson did not prove fruitless, and that the Declaration of Independence became an immortal document instead of passing into the waste-basket of forgotten revolutionary pronunciamentos. The success of Scott on the Niagara frontier in aid of the wonderful victories of the navy in the second war with Great Britain compelled the British to relinquish their control over our commerce through the right of search and acknowledge our rightful lines of frontier. The territorial expansion on the Gulf and the Pacific would have been impossible if the armies of Scott and Taylor had failed. The Union would have been disrupted and slavery perpetuated, in spite of the eloquence of Webster and Phillips and Sumner and the consummate genius of Lincoln, if Grant and Sherman had not understood the art of war. Finally, it was not alone the unanimous resolution of Congress that made Cuba free and incidentally brought us Porto Rico and the Philippines, a commanding position in the Orient and the recognition of our greatness as a world power, but vii 
also the skill, valor and endurance of the officers and men, ashore and afloat, who carried our arms to victory on both sides of the globe in a few short months of 1898 .

From the beginning, one hundred and thirty-six years ago, the army has been the willing and faithful subordinate of the civil power, and the indispensable instrument for carrying into effect the will of the people as expressed by their chosen representatives. In recent wars it has become an efficient instrument for that purpose. In 1812-15 we paid the deserved penalty, at Detroit and Sacketts Harbor, Bladensburg and Washington, of twelve years' deliberate neglect of the military service, due to the popular belief that a well-trained army was not a necessary factor in our scheme of government. It is not likely that we shall again make that mistake. Our army is to-day no larger in proportion to population, and much smaller in proportion to wealth, than after the close of any of the wars of the last century; but there is a constant effort to make it efficient; and while much remains to be done for the improvement of the militia, yet it is better organized and equipped than ever before in its history. The value of military instruction was never so widely recognized as it is to-day. The prejudice against a "standing army," which our ancestors brought over from England nearly three centuries ago, and which so long survived any reason for its existence, is at last almost extinct. The good conduct of the army, regulars and volunteers, and the inestimable value of their services, have nearly overcome this prejudice. We shall always have an army. There is every reason to believe that it will be efficient. To be so, it must study its past history and draw from it the lessons which are applicable to the future.

In the hope of aiding to some extent in this study, the following pages have been written.

A few words about the making of this book may not be out of place. 
1st. As to Purpose.-I have had it in mind to write such a book for more than twenty-five years, but various circumstances have caused constant postponement. I had originally intended to condense the entire history of our military operations, from Lexington to Pekin, into one volume of not over 400,000 words. Experience has shown that such extreme condensation would crush the life out of the book, and it is now evident that three volumes will be necessary. Under these circumstances I have decided to publish the first volume without waiting for the others.

2d. As to Text.-My private library includes nearly all the books named in the two lists of authorities. Those which are out of print and unpurchasable have been obtained from the Library of Congress, the State Library at Albany, the New York City Public Library, and the Library of Columbia University. I desire to express my thanks to the officers in charge of these libraries for the facilities which they have afforded to me in the use of their ample resources.

The book has been written with these authorities at hand, and citation is given for every fact. The opinions are my own, although I confess to being influenced by the simple, clear style and accurate thinking of the late John Fiske, and also in a minor degree by the brilliant, sympathetic and attractive history of Sir George Otto Trevelyan.

3d. As to Maps.-All, except one, of the maps in this volume have been previously published in Avery's "History of the United States and Its People," and it is to the courtesy of my fellow-graduate in the Class of 1870 at West Point and lifelong friend, Mr. Charles William Burrows, President of The Burrows Brothers Publishing Company, of Cleveland, that I am indebted for the great privilege of making use of them. They are the only maps of the Revolution that are accurate. They have been prepared in the only way in which accurate maps can be made-viz., by using careful topographical surveys (in this case those of the United States Geological Survey) 
as the basis, and placing on these the positions of the troops as stated in the official reports of the commanding generals, reconciling the discrepancies between different reports as well as possible. Most of them were drawn by Lieutenant Joseph Baer, United States Army, while on duty in the Department of Drawing at West Point in 1904.

The only map not taken from Avery's History is the map of Harlem Heights, which was drawn under the direction of Professor Henry P. Johnston for his admirable monograph on "The Battle of Harlem Heights." It is used by permission kindly given by him and by the Columbia University Press.

Prepared in this way all the maps have been engraved and printed at the Matthews-Northrup Works in a manner that leaves nothing to be desired.

4th. As to Proof-Reading and Indexing.-I am indebted to Captain Frederick W. Lewis, 29th Infantry, for valuable assistance in reading the proofs and comparing the texts with the maps. The Index has been prepared by the Publishers. Francis Vinton Greene.

May 1, 1911. 


\section{CONTENTS}

\section{PART I-THE REVOLUTIONARY WAR}

I.-BOSTON, 1775-76 . . . . . . . . . . . . . . . 1

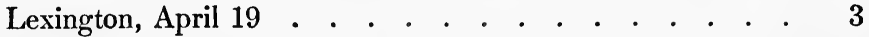

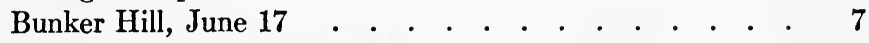

Siege of Boston, July, 1775-March, 1776 . . . . . . . 13

Dorchester Heights, March 4 . . . . . . . . . . . 18

Evacuation of Boston, March 17 . . . . . . . . . . 19

Invasion of Canada, September, 1775-July, 1776 . . . . 21

II.-NEW YORK, 1776 . . . . . . . . . . . . . . 28

British Plans for the Campaign of 1776 . . . . . . 28

Washington Marches to New York, April . . . . . . 31

Howe Arrives at New York, July-August . . . . . . . 33

Battle of Long Island, August 27 . . . . . . . . . 35

- Washington Retreats from Long Island, August 29 • . $\quad 42$

Action at Kip's Bay, September 15 . . . . . . . . . 46

- Battle of Harlem Heights, September 16 . . . . . . . 49

Howe's Flank Movement through Westchester, October . . 51

Battle of White Plains, October 28 . . . . . . . . 52

Battle of Fort Washington, November 16 . . . . . . 57

Retreat through New Jersey, November-December . . . 62

Washington Crosses the Delaware, December 25 . • • . 66

Battle of Trenton, December 26 . . . . . . . . . 67

Battle of Princeton, January 3, 1777 . . . . . . . . 70

Winter Quarters at Morristown, January 7 . . . . . 72

III.-PHILADELPHIA, 1777 . . . . . . . . . 。 . . . 75

Howe's Plans for 1777 . . . . . . . . . . . 76

Burgoyne's Plan, Approved by the King . . . . . . . 78

The Danbury Raid, April 25 . . . . . . . . . . 50 
The Middlebrook Manœuvres, May, June . . . . . . 80

Howe Sails for the Chesapeake, July 1. . . . . . . . 82

Washington Confronts Him When He Lands, August 25 . 83

Battle of the Brandywine, September 11 . . . . . . . 85

Paoli Massacre, September 21. . . . . . . . . . . 88

Howe Takes Philadelphia, September 25 . . . . . . . 88

Battle of Germantown, October 4 . . . . . . . . . 90

Defence of Fort Mercer, or Red Bank, October 22 . . $\quad$. 93

Capture of Fort Mifflin, November 15 . . . . . . . . 94

Evacuation of Fort Mercer, November 20 . . . . . . . 94

Washington at Valley Forge, December 19 . . . . . . 95

IV.-THE HUDSON, 1777 . . . . . . . . . . . . . 96

Burgoyne Arrives at Montreal, May 14 . . . . . . 100

Capture of Ticonderoga, July 6 . . . . . . . . . . 103

Battle of Hubbardton, July 7 . . . . . . . . . . . 104

Engagement at Skenesborough, July 7 . . . . . . . . 104

Action at Fort Ann, July 8. . . . . . . . . . . . 105

St. Leger's Expedition from Oswego, July-August . . . . 106

Battle of Oriskany, August 6 . . . . . . . . . . . 107

Siege of Fort Schuyler (or Stanwix), August 4-22 . . . . 108

Defeat of St. Leger, August 22 . . . . . . . . . 108

Schuyler Retreats Down the Hudson, July-August. . . . 109

Battle of Bennington, August 16 . . . . . . . . . . 113

Battle of Freeman's Farm, September 19 . . . . . . 116

Capture of Forts Montgomery and Clinton, October 6 . . 121

Battle of Bemis' Heights, October 7. . . . . . . . . 123

Surrender of Burgoyne at Saratoga, October 17. . . . . 127

V.-THE FRENCH ALLIANCE, 1778-S1 . . . . . . . 132

Valley Forge. . . . . . . . . . . . . . . 132

Conway Cabal . . . . . . . . . . . . . . . . 134

Greene Appointed Quartermaster-General . . . . . . 136

Steuben Appointed Inspector-General . . . . . . . . 137

British Peace Commission . . . . . . . . . . . . 138

Skirmish at Barren Hill, May 20,1778 . . . . . . . 140

Evacuation of Philadelphia, June 18 . . . . . . . . 141

Battle of Monmouth, June 28. . . . . . . . . . . 144

Court-Martial of Charles Lee, July 4-August 12 . . . . . 148

Arrival of the French Fleet, July 14 . . . . . . . . 149

Newport, August 29 . . . . . . . . . . . . . . 153 
Stony Point, July 16, 1779 . . . . . . . . . . . . 158

Paulus Hook, August 19 . . . . . . . . . . . 160

Penobscot Expedition, July 25 . . . . . . . . . . . 161

Springfield, June 23, 1780 . . . . . . . . . . . . 164

West Point-Arnold's Treason, September 21 . . . . . 167

New London, September 7, 1781 . . . . . . . . . . 170

Movements of d'Estaing, 1779 . . . . . . . . . . . 171

Arrival of the Second French Expedition, July 10, 1780 . . 172

French Army and Navy Blockaded at Newport, July, 1780,

to July, 1781 . . . . . . . . . . . . . . . . 173

The Revolution Nearly Exhausted . . . . . . . . . 174

Mutiny of the Pennsylvania Line, January 1,1781 . . . 176

Mutiny of the New Jersey Line, January 20 . . . . . 177

John Laurens's Mission to Paris, February 13 . . . . 178

VI.-BRITISH CONQUEST OF THE SOUTH, 1778-80 • . 180

British Plans for Dividing the Colonies . . . . . . . 182

Militia Conflicts . . . . . . . . . . . . . 183

Great Bridge, Va., December 9, 1775 . . . . . . . 183

Moore's Bridge, N. C., February 27, 1776 . . . . . . 183

Defence of Charleston, June 28 . . . . . . . . . . 186

Capture of Savannah, December 29, 1778. . . . . . . 191

Conquest of Georgia, January 29, 1779 . . . . . . . 192

Action at Beaufort, February 3 . . . . . . . . . . 193

Engagement at Kettle Creek, February 14 . . . . . . 194

Battle of Briar Creek, March 3 . . . . . . . . . . 195

Battle of Stono Ferry, June 20 . . . . . . . . . 198

Siege of Savannah, September 23 . . . . . . . . . 202

Assault at Savannah, October 9 . . . . . . . . . 203

D'Estaing Returns to France, October 20 . . . . . 205

Clinton's Expedition to the South, October 26 . . . . . 206

Siege of Charleston, April 10,1780 . . . . . . . . . 208

Surrender of Charleston, May 12 . . . . . . . . . 210

Action at the Waxhaws, May 29 . . . . . . . . . 212

Action at Ramsour's Mill, June 20 . . . . . . . . 213

Action at Williamson's, July 12 . . . . . . . . . . 213

Action at Hanging Rock, August 8 . . . . . . . . 213

Action at Rocky Mount, July 30 . . . . . . . . . . 214

Action at Green Spring, August 1 . . . . . . . . . 214

Action at Hanging Rock, August 12 . . . . . . . . 214 
Gates Takes Command, July 25 . . . . . . . . . . 215

Battle of Camden, August 16 . . . . . . . . . . . 218

Action at Fishing Creek, August 18, 1780 . . . . . . . 219

VII.-BRITISH DEFEAT AT THE SOUTH, 1781-82 . . 220

Greene Takes Command, December 4,1780 . . . . . 222

Battle of King's Mountain, October 7 . . . . . . . . 224

Action at Fish Dam, November 9 . . . . . . . . . 225

Action at Blackstocks, November 20 . . . . . . . . 225

Battle of the Cowpens, January 17, 1781 . . . . . . . 229

Retreat to the Dan, January, February . . . . . . . 232

Passage of the Catawba, February 1 . . . . . . . . 233

Passage of the Yadkin, February 8 . . . . . . . . 234

Passage of the Dan, February 15 . . . . . . . . . 235

Action at Wetzell's Mill, March 6 . . . . . . . . . 237

Battle of Guilford, March 15 . . . . . . . . . . . 239

Cornwallis Retreats to Wilmington, April 7 . . . . . . 242

Greene Marches to South Carolina, April . . . . . . 244

Battle of Hobkirk's Hill, April 25 . . . . . . . . . 246

Rawdon Evacuates Camden, May 10 . . . . . . . . 248

Capture of Fort Motte, May 12 . . . . . . . . . . 248

Capture of Orangeburg, May 11 . . . . . . . . . . 249

Capture of Fort Granby, May 15 . . . . . . . . . . 249

Siege and Capture of Augusta, May 22-June 5 . . . . . 249

Siege of Ninety-Six, May 22-June 19 . . . . . . . 250

Battle of Eutaw Springs, September 8 . . . . . . . 255

Evacuation of Savannah, July 11, 1782 . . . . . . . 257

Evacuation of Charleston, December 14, 1782 . . . . . 257

VIII.-YORKTOWN, 1781 . . . . . . . . . . . . . . 259

Cornwallis Marches to Virginia, April . . . . . . . 260

Situation in Virginia, May. . . . . . . . . . . . 261

Lafayette Retreats from Richmond, June . . . . . . 262

Steuben Retreats from Charlottesville, June . . . . . 262

Arrival of Wayne, June 10 . . . . . . . . . . . 263

Battle of Jamestown, July 6 . . . . . . . . . . . . 263

Clinton's Instructions to Cornwallis, June-July. . . . . 266

Cornwallis at Yorktown, August 2 . . . . . . . . . 267

Allied Army Moves Toward New York, June . . . . . 268

Allied Army Marches to Virginia, August . . . . . . 270

Movements of French and English Fleets, August . . . 270 
Chapter

Naval Battle off the Chesapeake, September 5 . . . . 273

Clinton Sails to Relief of Cornwallis, October 19 . . . . 273

Siege of Yorktown, September 28 . . . . . . . . . 274

Capitulation at Yorktown, October 19 . . . . . . . 275

End of the War, November 25, 1783 . . . . . . . . 278

Washington's Ability as a Soldier . . . . . . . . . 279

\section{PART II-THE MILITARY POLICY OF THE UNITED STATES}

Ancient Origin of the Prejudice against a Standing Army • . 286

Formation of the Continental Army, 1775 . . . . . . . . 288

Washington's Opinions on the Defects of the System in Use During

the Revolution, . . . . . . . . . . . . . . . 292

The Constitutional Powers of Congress . . . . . . . . . . 295

The Manner of Raising Troops for the War of 1812 . . . . $\quad 297$

Secretary Calhoun's Reports, 1818-20 . . . . . . . . . . . 299

Volunteers and Militia for the Florida War, 1835 . . . . . . 301

Calling Out Troops for the Mexican War, 1846 . . . . . . . 305

The Enormous Levies for the Civil War, 1861-65 . . . . . . 307

Reduction of the Army after the Civil War . . . . . . . . . 311

Report of the Burnside Committee in 1878 . . . . . . . . 312

New Methods Adopted for Raising Troops in the War with Spain,1898 315

United States Volunteers for the Philippines, 1899 . . . . . . 319

Secretary Root's Reports and Resulting Legislation, 1901-03 . . . 320

Organization and Duties of the General Staff . . . . . . . . 325

The Militia Act of 1903 . . . . . . . . . . . . . . 327

The Necessity for a Definite Military Policy to Meet Existing Conditions . . . . . . . . . . . . . . . 331

APPENDIX . . . . . . . . . . . . . . . . . . 337

INDEX . . . . . . . . . . . . . . . . . . . 343 


\section{MAPS}

Lexington and Concond, April 19, 1775 Bunker Hill, June 17, 1775 . . . . . . . . . . . . . . 6

Boston, July, 1775-March, 1776 . . . . . . . . . . . . . 12

Invasion of Canada, September, 1775-July, 1776 . . . . . . . 20

Arnold's March, September 5-November 13, 1775 . . . . . . 22

Quebec, December 31, 1775 . . . . . . . . . . . . . . 24

New York, April-November, 1776 . . . . . . . . . . . . 28

Long Island, August 27, 1776 . . . . . . . . . . . . . 36

Harlem, September-October, 1776 . . . . . . . . . . . . 48

White Plains, October 28, 1776 . . . . . . . . . . . . . 52

Movements of Nathan Hale, September 10-22, 1776 . . . . . . 52

Fort Washington, November 16,1776 . . . . . . . . . . . 56

Retreat through New Jersey, November-December, 1776 . . . . 60

Trenton, December 25, 1776 . . . . . . . . . . . . . . 66

Trenton and Princeton, January $2-4,1776$. . . . . . . . . 66

Philadelphia, August-December, 1777 . . . . . . . . . . . 76

Fort Washington, November 16,1776 . . . . . . . . . . . 80

Danbury Raid, April 25-26, 1777 . . . . . . . . . . . . 30

Brandywine, September 11, 1777 . . . . . . . . . . . 84

Fort Mercer, October 22, November 20, and Fort Mifflin, November 15,1777 . . . . . . . . . . . . . . . . . 84

Germantown, October 4, 1777 . . . . . . . . . . . . . 92

Arnold's Naval Engagement, October 11-13, 1776 . . . . . . . 96

The Hudson, July-October, 1777 . . . . . . . . . . . . 96

Ticonderoga, July 6, 1777 . . . . . . . . . . . . . . . 102

Hubbardtown, July 7, 1777 . . . . . . . . . . . . . . 102

Bennington, August 16,1777 . . . . . . . . . . . 102

Freeman's Farm, September 19, 1777 . . . . . . . . . . . 116

Bemis Heights, October 7, 1777 . . . . . . . . . . . 122

Fort Schuyler, August 3-22, 1777 . . . . . . . . . . . 126 
Forts Montgomery and Clinton, October 6, 1777

Surrender of Burgoyne, October 17, 1777 . . . . . . . . . 126

Valley Forge, December 19, 1777-June 17, 1778 . . . . . . . 132

Philadelphia Evacuated, June 18, 1778 . . . . . . . . . . 132

Barren Hill, May 20, 1778 . . . . . . . . . . . . . . . 146

Monmouth, June 27, 1778 . . . . . . . . . . . . . . . 146

The French Alliance, Movements between New Jersey and Newport,

1778-1781 . . . . . . . . . . . . . . . . . . 150

Springfield, June 23,1780 . . . . . . . . . . . . . . . 152

Penobscot, July 25, 1779 . . . . . . . . . . . . . . . 152

New London, September 7, 1781 . . . . . . . . . . . . 152

Newport, August 29, 1778 . . . . . . . . . . . . . . 152

Sullivan's Indian Campaign, 1778-1779

Stony Point, July 16, 1779 . . . . . . . . . . . . . . . 158

Tryon's Raid, July 5-8, 1779 . . . . . . . . . . . . . . 158

Arnold's Treason. Andre's Capture, September 20-25, 1780 . . . 166

Boston to Savannah, 1776-1781 . . . . . . . . . . . . . 186

Sullivan's Island (Charleston), June 29, 1776 . . . . . . . . 186

South Carolina, 1779-1780 . . . . . . . . . . . . . . . 192

Savannah, October 9,1779 . . . . . . . . . . . . 202

Charleston, April 10-May 12, 1780 . . . . . . . . . . . 202

King's Mountain, October 9,1780 . . . . . . . . . . . . 218

Camden, August 16, 1780 . . . . . . . . . . . . . 218

Campaign of 1781 . . . . . . . . . . . . . . . . . . . 226

Retreat to the Dan, January-February, 1781 . . . . . . 232

Cowpens, January 17,1781 . . . . . . . . . . . . . 238

Guilford, March 15, 1781 . . . . . . . . . . . . . 238

Hobkirk's Hill (Camden), April 25, 1781 . . . . . . . . . . 246

Ninety-Six, May 22-June 5, 1781 . . . . . . . . . . . 246

Eutaw Springs, September 8, 1781 . . . . . . . . . . 254

Virginia, 1781 . . . . . . . . . . . . . . . . . . . 258

Petersburg, April 25, 1781 . . . . . . . . . . . . . . . 260

Chesapeake, September 5, 1781 . . . . . . . . . . . 260

Richmond, January 6, 1781 . . . . . . . . . . . 260

Yorktown, September 30-October 191781 . . . . . . . . . 274 


\section{AUTHORITIES}

\section{A.-THE REVOLUTIONARY WAR}

1. Force's “American Archives," 4th series, 6 vols.; 5th series, 3 vols., 1774-76 (Amer. Archives).

2. Journals of Congress, edition of 1823, 4 vols., 1774-83 (Jour. Cong.).

3. Journals of the Continental Congress, edition of 1906, 15 vols., 1774-79 (Jour. Cont. Cong.).

4. Sparks's “Writings of Washington," 12 vols. (Sparks).

5. Sparks's “Letters to Washington," 4 vols. (Sparks, Letters).

These 44 volumes correspond in some measure (though much less complete) to the Official Records of the War of the Rebellion. They contain the greater part of all the original documents that have been published on the American side, except such as have been brought out in memoirs and biographies of the minor characters of the Revolution.

6. Dawson's "Battles of the United States," vol. I (Dawson).

7. Lossing's “Field-Book of the Revolution," 2 vols. (Lossing).

Dawson is valuable on account of the copious references he makes to original documents. Lossing visited every battle-field of the Revolution between 1847 and 1850 .

8. E. J. Lowell's "The Hessians in the Revolution" (Lowell). This is founded upon original German authorities.

9. Eelking's German Allies in the American Revolution (Eelking).

10. Heitman's "Officers of the Continental Army" (Heitman). This contains a brief account of every regiment and every officer of the Continental army, as shown by the records of the War Department.

11. Frothingham's "Siege of Boston" (Frothingham).

12. H. P. Johnston's "Campaign of 1776 Around New York and Brooklyn" (Johnston, 1776).

13. H. P. Johnston's “Battle of Harlem Heights” (Johnston, Harlem).

14. H. P. Johnston's "Stony Point” (Johnston, Stony Point).

15. H. P. Johnston's "Yorktown Campaign" (Johnston, Yorktown).

16. Stryker's "Trenton and Princeton" (Stryker).

17. Moore's "Treason of Charles Lee" (Moore).

18. Keim's “Rochambeau” (Keim).

19. I. N. Arnold's "March to Quebec" (Arnold's March).

20. I. N. Arnold's “Benedict Arnold” (Arnold).

21. Kapp's "Steuben” (Kapp, Steuben).

22. Kapp's “Kalb” (Kapp, Kalb).

23. D. Schenck's “North Carolina 1780-81" (Schenck).

These nineteen books are exhaustive memoirs which contain probably every original fact and figure which is known concerning the respective events of which they treat. 
24. Howe's "Narrative, 1781" (Howe).

25. Burgoyne's "Narrative, 1780" (Burgoyne).

26. "Clinton-Cornwallis Controversy," B. F. Stevens, 1888 (ClintonCornwallis).

27. Tarleton's "Campaigns of 1780 and 1781" (Tarleton).

28. Riedesel's "Memoirs," 2 vols. (Riedesel).

29. Hansard's "Parliamentary History of England," vols. XVII-XXIII, 1775-83 (Hansard).

These, together with Force and Dawson, are the chief sources of British official reports and maps. Stevens's compilation of the documents relating to the campaign of 1781 is unique.

30. Stedman's “American War,” 2 vols., 1794 (Stedman).

This was written by a very competent officer who served in the British army from Boston to Yorktown. Its maps are valuable as historical documents although inaccurate as to topography.

31. Winsor's "Reader's Handbook of the American Revolution," 1 vol., 1879 (Winsor).

In this full bibliography the librarian of Harvard University gives a chronological list of the events of the Revolution and, as to each event, a reference to the volume and chapter of every book and every map of any value which had been published in relation thereto. He properly styles it "a continuous foot-note to all histories of the American Revolution."

The standard histories-Gordon, Ramsay, Botta, Hildreth, Bancroft, Fiske, Avery and (most brilliant and, I believe, most accurate of them all) Trevelyan; the contemporary journals of Moultrie Henry Lee, Thacher and Simcoe; the earlier biographiesSparks's "American Biographies," Marshall's "Washington," Irving's "Washington," Johnson's "Greene," G. W. Greene's "Greene," Drake's “ Knox," Reed's “Reed,” Bowen's “Lincoln," Stark's "Stark"; all these are well known. Probably no one hav read them all; certainly I have not. I have, however, consulted each of them as to their opinions on certain important events. They are all founded on the original documents above listed, or on personal recollections, but are not in themselves original authorities. In addition to these there are, of course, hundreds of other books on the Revolution, the bibliography of which is very voluminous.

\section{B.-MILITARY POLICY}

1. Force's "American Archivcs," 4th series, 6 vols.; 5th Series, 3 vols., 1774-76 (Amer. Archives).

2. "American State Papers, Military Affairs," 7 vols.

These stout quartos, 16 volumes, about 1600 pages per volume, $18,000,000$ words in all, were published by Peter Force, under authority of Congress, in the years 1837 to 1853 . They are the chief repository of facts and figures relating to military affairs from 1774 to 1830 .

3. “Journals of Congress," edition of 1823, 4 vols., 1774-83 (Jour. Cong.). 
4. “Journals of the Continental Congress," edited by Worthington C. Ford, and published by authority of Congress in the years 1904 to 1909 . They number 15 volumes and contain a verbatim copy, including interlineations, erasures and corrections, of the original journals in the archives of the State Department for the years 1774 to 1779 . The copying and printing of the journals for the succeeding years is now in progress (Jour. Cont. Cong.).

5. Sparks's "Writings of Washington," 12 vols., 1858 (Sparks).

6. Sparks's "Letters to Washington," 4 vols., 1853 (Sparks, Letters).

7. "Military Laws of the United States." Compiled by J. F. Callan, 1862 (Mil. Laws).

8. "Military Laws of the United States." Prepared by Lt.-Col. Geo. B. Davis, Dep'y Judge Advocate General, U. S. Army, 1897 (Mil. Laws, 1897).

9. "Military Laws of the United States," 4th edition, 1901. With supplement to March 4, 1907, prepared by Major John B. Porter, Judge Advocate, U. S. Army (Mil. Laws, 1907).

10. Henry Adams's "History of the United States, 1801-1817," 9 vols., 1890 (Adams).

11. Provost Marshal General's Report. War of the Rebellion. Official Records of the Union and Confederate Armies (War Records). This report contains complete statistics on all matters relating to the recruiting of the Northern armies and the enforcement of the Conscription Laws of 1863.

12. Reports of the Commissioner of Pensions (Com. Pensions).

13. Upton. "Military Policy of the United Siates." Written in $\mathbf{1 8 8 0 .}$ Published (after General Upton's death) by the War Department in 1904 (Upton).

14. Burnside Committee Senate Report 555. 45th Congress, 3d Session, Dec. 12, 1878 (Burnside).

15. "Messages of the Presidents." Compiled and published by J. D. Richardson, 9 vols. (1898), under authority of Congress (Mess. Presidents).

16. Revised Statutes of the United States. 1878 (Rev. Stat.).

17. Army Registers. 1860 to 1910 (Army Reg.).

18. Register of the Graduates of the U. S. Military Academy (Grad. U. S. M. A.).

19. Cullum's Biographical Register of the Graduates of the U. S. Military Academy (Cullum).

20. Report of the Secretary of War, 1898 (Sec. War).

21. Report of the Adjutant-General U. S. Army, 1898 (Adjt.-Gen.).

22. Reports of the Chief of Staff (Chf. Staff).

23. Reports of the Secretary of War, 1899-1903, reprinted in one volume, 1904 (Sec. War) 


\section{PART I THE REVOLUTIONARY WAR}

"The problem, that a nation can be defended against a permanent force, by temporary armies, by occasional calls of the husbandman from his plough to the field, was completely disproved; and, in demonstrating its fallacy, the independence of America had nearly perished in its cradle."

-John Marshall. 



\section{CHAPTER I}

\section{BOSTON $^{1}$}

THE relations between England and her American co-

onies, which had been growing more and more strained concord and during the twelve years following the close of the French Lexington war in 1763, reached a crisis on an April morning when April 19 the royal troops were sent out from Boston to destroy military stores at Concord-and incidentally to arrest Samuel Adams and John Hancock, on the way, at Lexington. The political consequences of that day were stupendous. In a military sense its importance was due to the fact that the grenadiers and light infantry, excelled by none in the British army for training, discipline and military experience, after killing eight farmers on the Lexington Common, met such a sturdy resistance from the rustic militia at Concord that they beat a hasty retreat to Boston; and on the way back, although reinforced by a brigade of regulars under command of the eldest son of the Duke of Northumberland, were so surrounded, ambushed, outflanked and assaulted by the hordes of gathering militia, that they barely escaped

${ }^{1}$ The story of Lexington and Concord and Bunker Hill has been told many thousand times in books and orations. The one exhaustive and complete account, vivid in narrative and replete with official documents, is that given in The Siege of Boston, by Richard Frothingham, published by Little \& Brown in 1849 and reprinted in 1903 . The notes and references in that book to the original authorities are so copious that a general reference to Frothingham only is necessary here. The original authorities are quoted there in every instance. 
1775 complete capture, and left 73 killed, 174 wounded and 26 missing on the road; a total loss equal to 15 per cent of their strength.

The Massachuset ts Army

Within a week the British troops were shut up and besieged in Boston by a force of nearly 20,000 "minutemen"-that portion of the Massachusetts militia, one in four, who were designated to answer any call at a minute's notice. But the minute-men, determined as they were and actuated by intense patriotism, came and went according to their own estimate of the relative importance of their agricultural and military duties; the Massachusetts Congress thereupon began the formation of an "army," whose strength they thought should be 30,000 men, of which their own colony should furnish 13,600 . The adjoining colonies were asked to contribute their quota, and New Hampshire, Connecticut and Rhode Island promptly responded. The troops were enlisted until the end of the year, were organized into regiments, and Artemas Ward was appointed general and commander-in-chief.

The British Garrison

The garrison of Boston, which remained closely besieged until its evacuation nearly a year later, consisted at this time of eleven infantry regiments, many of which became famous under Wellington's command nearly forty years later, some artillery and a few marines from the squadron of several men-of-war then lying in the harbor under command of Admiral Graves. It numbered about 3,500 men, organized into three brigades, under Brigadiers Earl Percy, Pigott and Jones. The commander-in-chief was Major-General Thomas Gage, who had been a lieutenant-colonel under Braddock, had served through the French war and then been promoted and assigned to command all the troops in America. He had visited 



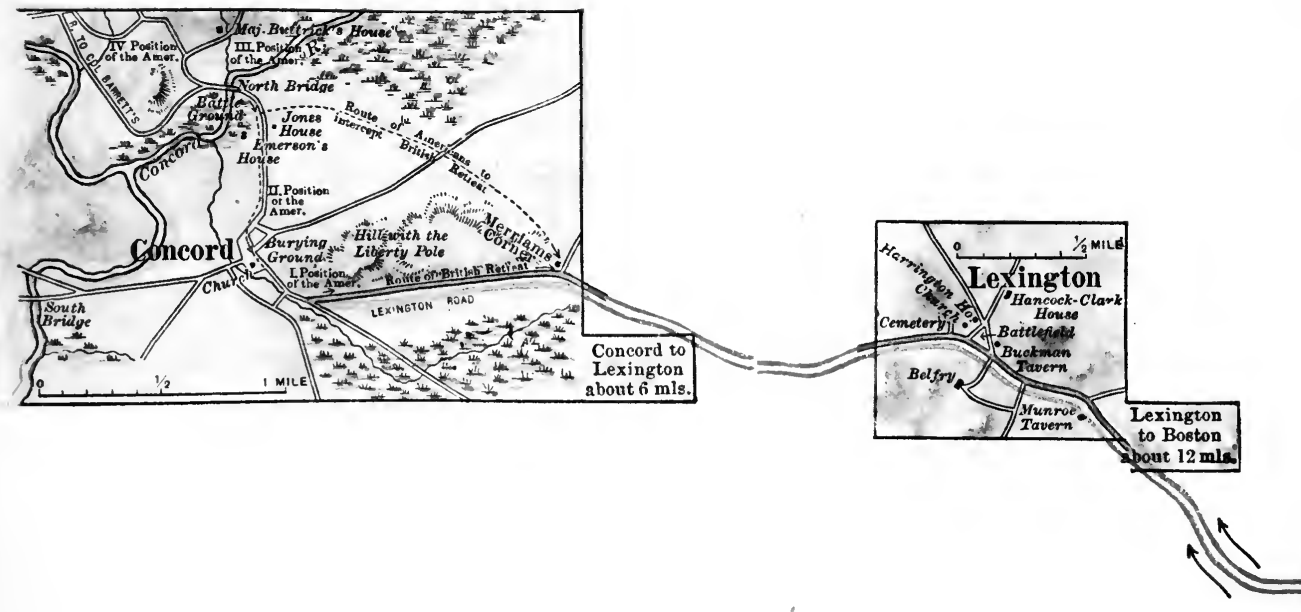

1

LEXINGTON AND CONCORD

April 19, 1775 
England in 1773 and returned in the spring of 1774 as Governor of Massachusetts, in addition to his military duties.

Six months after his arrival he reported to the Secretary for the Colonies that "if the misunderstandings proceed to the last extremity, to begin with an army of 20,000 men will in the end save Great Britain both blood and treasure." But the minister considered what was transpiring in Massachusetts to be "the acts of a rude rabble, without plan, without concert, without conduct"; ${ }^{1}$ and he thought a smaller force quite sufficient, if used promptly and vigorously. Later, however, he so far changed his mind as to send out three major-generals, Burgoyne, Howe and Clinton, all of whom had had military experience and were also sitting as Members of Parliament. They brought with them several additional regiments, May 25 carrying the total strength of the garrison to about 10,000 men.

Gage had previously thrown up some earthworks near Boston Neck, on the site of what is now Dover Street, The Fortification at Boston commanding the road over the narrow causeway which connected Boston, then almost an island, with the mainland. As soon as Ward's regiments began to arrive, they also undertook the construction of field-works, covering all the roads leading to the west and south of Boston, and designed to prevent any further incursions of the British troops like that of Concord. These works were skilfully located, planned and constructed under the direction of Colonel Richard Gridley, chief engineer, who was now sixty-four years old, but had lost none of the great reputation he had acquired at the siege of Louisburg, thirty years before. The works were not fully ${ }^{1}$ Sparks, III, 506-507. 
completed until several months later, but ultimately they comprised nineteen distinct groups of redoubts and trenches covering a space of nearly twelve miles, from the Mystic River on the left to Dorchester on the right; the centre was at Cambridge, where Ward now had his headquarters, and where Joseph Warren directed the sessions of the Provincial Congress and the Committee of Safety.

Lack of

Cannon

April 29

But cannon were lacking to man these field-works. There were only twenty-three small pieces of artillery in the colony. Therefore a proposition of Captain Benedict Arnold was eagerly accepted. He had arrived at Cambridge with a fine company from New Haven, and reported to the Committee of Safety that the forts at the southern end of Lake Champlain were feebly garrisoned and in bad condition, but that they contained more than 100 cannon of various sizes from 4-pounders to 20pounders. ${ }^{1}$ He asked permission to attack and capture these forts. The committee quickly acceded, made him a colonel, authorized him to raise 400 men and sent him May 8 on his errand. When he reached the vicinity of Lake Champlain he found a party of about 200 men, "Green Mountain Boys," under command of Colonel Ethan Allen, bent on the same mission, by permission of the Connecticut Assembly. Arnold's men had not arrived, so he joined Allen as a volunteer, and by a brilliant

Capture of Ticonderoga and Crown Point coup they captured Ticonderoga at dawn on May 10, and Crown Point two days later. Arnold made a careful return of the ordnance stores and the cannon, of which there were 197, and he reported 87 of them serviceable. ${ }^{2}$ Some of the lighter calibres were speedily sent to Cambridge, according to Colonel Gridley's instructions, but the larger guns had to wait for next

${ }^{1}$ Amer. Archives, 4, II, 450.

${ }^{2}$ Ibid., 4, II, 646. 


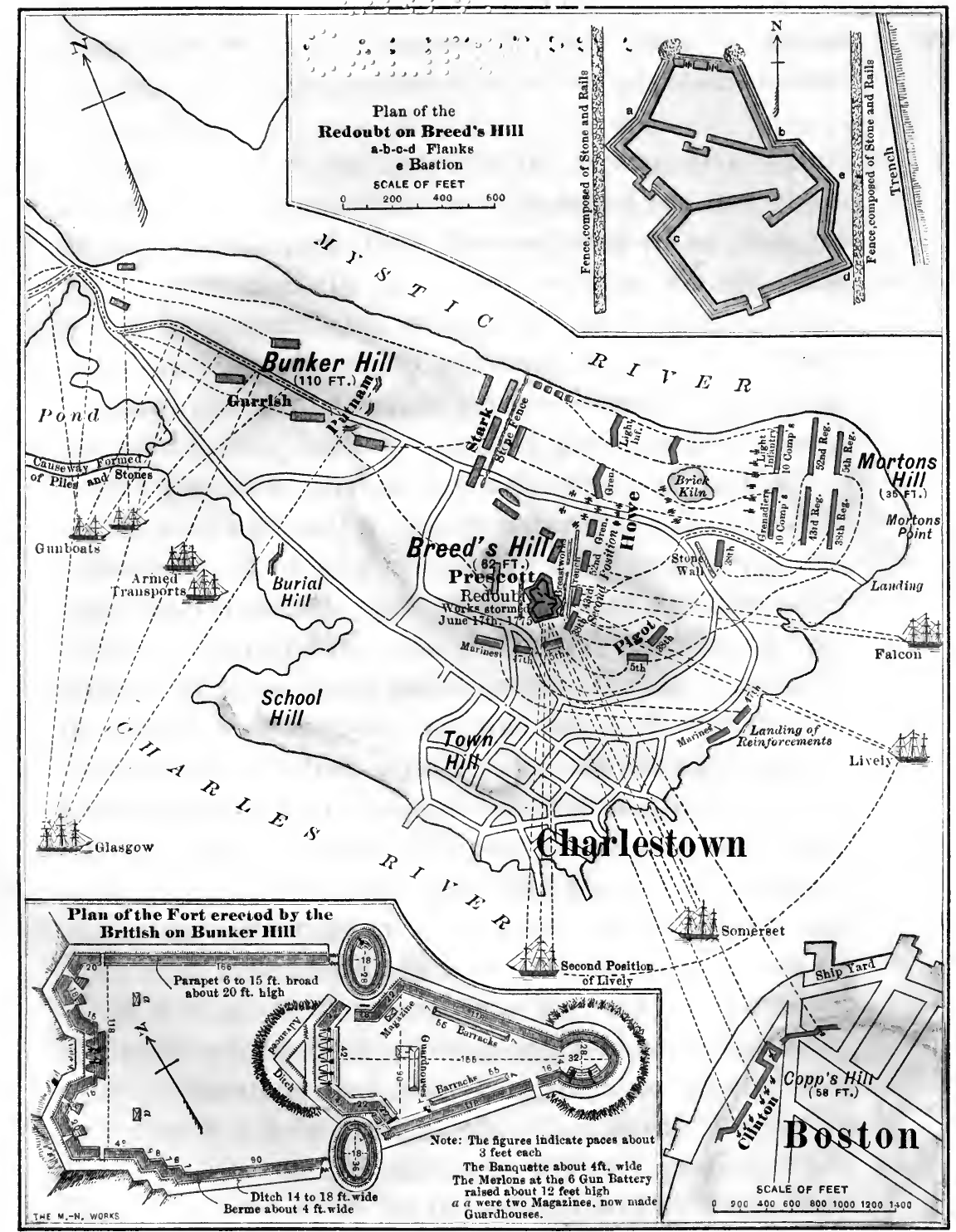

Courtesy of The Burrows Brothers Company, Publishers, Cleveland, Ohio

2

Bunker Hill.

June I 7, I 775 


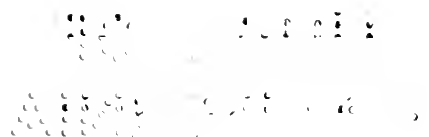

$\ell$ 
winter's snow and sledges before they could be transported. They then arrived in time to compel the evacuation of Boston.

While these fortifications were progressing, Gage issued June 12 an insulting proclamation, ${ }^{1}$ said to have been draughted by Burgoyne, and the Massachusetts Committee of Safety responded by a resolution ${ }^{1}$ that Bunker Hill, June 15 which commanded Boston on the north, ought to be occupied. Gage was also planning to occupy this hill, and news of his intention had reached the Colonial army. Both sides were eager to fight, the Americans to answer Gage's proclamation and the British to avenge the disaster at Lexington. A bloody battle was the result.

On the evening of June 16, Colonel Prescott was sent from Cambridge with three regiments and a fatigue party Battle of Bunker Hill to fortify Bunker Hill. Either through mistake, or from a desire to place his redoubt as near Boston as possible, he passed over Bunker Hill and selected Breed's Hill. Colonel Gridley, chief engineer, laid out a square redoubt about 40 yards on a side, and the work began about midnight. Before daylight the parapets were 6 feet high, with banquettes of wood and earth from which the men could fire. A breastwork of similar height, about 100 yards long, extended from the north-east angle of the redoubt toward the Mystic River. The site of the redoubt is that on which Bunker Hill monument now stands.

The operations had been conducted so quietly that they had not been detected by the British. At dawn, Gage's Plan of Attack about 4 A. M., the redoubt was observed, and fire was June 17 opened on it by one of the men-of-war and by the battery on Copp's Hill, in Boston. Gage called a council of war, and rejecting the advice of Clinton, determined to assault

${ }^{1}$ Amer. Archives, 4, II, 968, 1354 
1775 the works in front, instead of cutting them off in the rear. The assaulting party was to be under the command of General Howe, and to consist of the grenadier and light infantry companies of ten regiments supported by four full regiments, 5th, 38th, $43 \mathrm{~d}$ and $52 \mathrm{~d}$. The 47 th Regiment and a battalion were to assemble at the North Battery prepared to cross, if necessary. While the troops were crossing the river and forming for attack, a furious cannonade was to be opened from the works at Boston Neck in the hope of creating a diversion, and preventing reinforcements being sent to Bunker Hill from Cambridge.

These movements were all made as planned. About noon the troops embarked at Long Wharf and North Battery, and were rowed to Morton's Point and landed without opposition, under cover of the guns of Copp's Hill and the six men-of-war, which at a range of 800 to 1,000 yards swept the ground on all sides of the redoubt but without doing much damage. About 2 o'clock the boats were sent back to North Battery and there embarked the 47th and the marines, landing them, however, near the present navy-yard, about 500 yards to the left of Howe's main body.

Prescott meanwhile completed the work on his fortifications and strengthened a rail-fence and hedge extending from the end of his breastwork to the shore of the Mystic, with a re-entrant angle which gave cross-fire in its front. He also asked for reinforcements, and Ward sent him two additional regiments from Cambridge, and a little later portions of several other regiments. With them came as volunteers Generals Putnam, Pomeroy and others who fought with muskets, and just before the attack opened Joseph Warren, President of the Provincial 
Congress, the active spirit of the Committee of Safety, who had been appointed a major-general by the Provincial Congress three days before, also arrived and took his place within the redoubt. The command, however, remained with Colonel Prescott, a most gallant and capable soldier.

Howe's men were in dress uniform, with knapsacks, Howe's three days' rations, cartridge-box, ammunition and mus- for Assault ket, the total load being estimated by Stedman ${ }^{1}$ at 125 pounds; doubtless it weighed less, but it probably seemed as much in the excessive heat of the cloudless summer day. Howe leisurely formed his command in three lines at a distance of 600 yards, and at 3 o'clock in the afternoon began the attack. Personally he advanced with the right wing against the rail-fence, while Brigadier Pigott with the left wing marched against the breastwork. The houses in Charlestown were set on fire by carcasses from Copp's Hill, but a gentle breeze from the north blew the dense smoke to one side so that it did not conceal the attacking troops. These came forward in fine order, the advance being covered by the fire of their artillery, and the infantry occasionally firing, but without effect. The Americans were restrained by their officers from firing until the British lines were within forty yards from the redoubt on one side and the rail-fence on the other. Then they opened fire, deliberately, with careful aim and with terrible effect. The British loss was enormous, particularly among the officers, who led their men with great gallantry and at this short range could easily be distinguished. The line hesitated, recoiled and then turned in hasty retreat back almost to the point whence it had started. 
1775

Second Assault

Third Assault

American Retreat

Howe reformed his men and led them forward a second time, in the same manner, firing as they advanced, and stepping over the bodies of those who had fallen in the first assault. This time the Americans held their fire until the British were within twenty yards (for powder was scarce and precious) and then delivered it with the same fatal effect. The British stood it for a few minutes, returning the fire with spirit, but the losses were so great that they were again compelled to retreat. Clinton, who had been observing the battle from Copp's Hill, now crossed the river with a second battalion of marines and some other troops and aided in rallying the regiments as they retreated to the beach.

Howe was determined, notwithstanding his enormous losses, to renew the assault, and in spite of reluctance on the part of some of his officers and men, he formed them for a third attack. The men were ordered to throw off their knapsacks, to move forward in column, reserve their fire and rely on the bayonet. Ágain in person Howe led the grenadiers and light infantry against the breastwork and rail-fence on his right, while Pigott accompanied by Clinton assaulted the redoubt on his left. This time he succeeded. The Americans had fired about thirty rounds in the two preceding assaults, and now had only two rounds left, made up by tearing open what remained of the artillery cartridges. They reserved their two rounds to the last, but when these had been fired they were helpless, for they had no bayonets. The British came over the parapet of the redoubt from three sides at once, there was a hand-to-hand fight, and then the Americans were forced out of the redoubt, Warren being killed just after the retreat began. It continued in fairly good order, Putnam covering the rear with his Connecticut regiment; 
the principal losses on the American side occurred during the retreat over Bunker Hill, the British keeping up a vigorous fire to which the Americans could not reply for lack of ammunition. About 5 o'clock the British halted their pursuit at Charlestown Neck, and the battle was over. The Americans filed into their lines on Prospect Hill and Winter Hill, expecting to be attacked there; but Howe decided that such an attack would be unwise.

In the eight years of the Revolution there was no battle more bloody, none more important. The Americans, without proper organization, equipment or supplies, had fought the best regular troops of Europe, and had repulsed them until their ammunition gave out. All the advantages of victory were on their side, and they were convinced that they could do it again and that regular organization was not necessary-a conviction which they tenaciously held throughout the Revolution; and then transmitted it to their descendants, who have believed in it almost to this day. On the British side, as soon as news of the battle reached England, Gage was recalled in disgrace and disappears from history. Howe, who had showed the greatest personal gallantry and exposed himself perhaps unnecessarily, was said to have been completely unnerved. Of the eleven officers on his staff, all were wounded, and ten died of their wounds within a few days or weeks. The memory of the carnage on that hot summer's afternoon never left him. He failed to press home his victory at Long Island; he was slow in pursuing Washington through New Jersey; he was cautious and timid in his manœuvres at Middlebrook; he did not reap the full advantage of his victories at Brandywine and Germantown; and he made no effort to attack Washington at Valley Forge. While his personal courage

Results of the Battle 
1775 did not flinch, he lacked moral courage, initiative and vigor throughout the two years in which he exercised supreme command after Gage's departure.

Losses Gage's report says that he sent 2,000 men into action and that his losses were 1,054 , or 53 per cent. Doubtless he underestimated the number engaged, for the losses were in 14 regiments of infantry, 1 of artillery and 2 battalions of marines. Their numbers could hardly have been less than 3,500. There were, according to his own report, 228 killed and 826 wounded, and about 1 in 10 were officers. On the American side all or parts of 15 regiments were engaged, 12 from Massachusetts, 2 from New Hampshire and 1 from Connecticut. Their numbers were never accurately ascertained, but were estimated at from 1,500 to 5,000; probably there were about 3,500, the same as the British. Their losses were 441: 140 killed, 271 wounded and 30 prisoners. Five out of six pieces of artillery were lost.

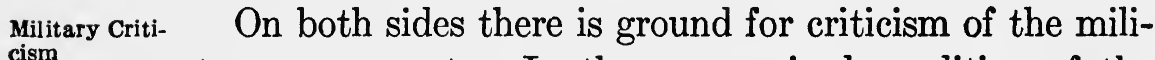
tary movements. In the unorganized condition of the Massachusetts army it was most unwise to bring on a general engagement; the British were shut up in Boston, and every road leading into the country was well guarded and fortified. The proper course to pursue was that followed by Washington after he arrived, viz., to await attack within their lines. In such an attack all the advantages would have been on the American side.

On the other hand, Gage's plan of attack was most faulty. He had the co-operation of the navy, with 7 vessels and 200 guns. $^{1}$ The Mystic and Charles Rivers were navigable for these ships, and they enveloped the Charlestown peninsula, which was then connected with ${ }^{1}$ Stedman, I, 123. 


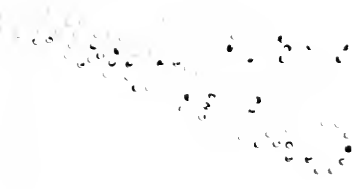


the main-land by a narrow causeway. Had Gage landed

his troops near this causeway, in Prescott's rear and under the protection of the fleet with such a vast preponderance of artillery, the capture or annihilation of the American force would seem to have been inevitable. In place of that he decided on an open assault, the first in a long list in our history of direct assaults over an open country against field intrenchments. Some of these assaults have succeeded, but the most have failed. In this case it was unjustifiable because unnecessary - other and better plans being available.

Both sides were, in fact, spoiling for a square stand-up fight, and this overruled all other considerations. Like Bull Run, eighty-six years later, Bunker Hill cleared the air, and showed to all concerned that there was a desperate struggle ahead. The Americans, more than ever-if that were possible-conscious of the justice of their cause, were now confident of their ability to win it. And the British were equally amazed and depressed by the obstinate and masterful resistance which they had encountered.

While these events were in progress at Boston, the congress Continental Congress, in session at Philadelphia, was control. arranging to assume control of the contest on behalf of all the colonies. It took over the armies of Massachusetts, Connecticut, New Hampshire and Rhode Island, assembled at Boston, as the "Army of the United Colonies," appointed Washington its commander-in-chief, adopted rules and regulations for its government (the first edition June 15 of the Articles of War), called upon the other colonies to raise reinforcements for the army, adopted measures for the manufacture of saltpetre and gunpowder and the casting of cannon, appointed a Board of War, authorized 
Appointment of General Officers

The MajorGenerals.

the raising of $\$ 2,000,000$ by bills of credit and took other steps to carry on the contest, including the appointment of four major-generals and eight brigadiers. ${ }^{1}$

The selection of Washington was due in part to the reputation he had gained in his service under Braddock, but perhaps even more to the fact that he was the most influential man in Virginia. His appointment was brought about by John Adams ${ }^{2}$ in the hope that it would bring Virginia and other Southern colonies to the aid of New England. No one could then foresee that in the next few years Washington would display those preeminent qualities as soldier, leader and statesman which have made him immortal.

The major-generals were Artemas Ward, Charles Lee, Philip Schuyler and Israel Putnam. Ward was selected out of deference to Massachusetts, whose troops he commanded; he remained through the siege of Boston and then resigned. Lee was supposed to be an accomplished soldier of large experience, but proved to be an adventurer, a charlatan and a traitor. Schuyler was one of the most prominent men in New York, had served with credit in the Indian wars, and was a capable soldier, ultimately forced out of the army by the intrigues of Gates. Putnam had served at Ticonderoga and Montreal and Havana, and had a great reputation for intrepid daring as well as for his popular manners. Although at the time of his appointment he only commanded a regiment, he held a commission as brigadier-general from Connecticut.

The brigadiers were Seth Pomeroy, William Heath and John Thomas, of Massachusetts; Richard Montgomery, of New York; John Sullivan, of New Hampshire; David

1 Jour. Cont. Cong., II, 91, 93, 99.

'Morse's Life of John Adams, 92, 100; Sparks, III, 479-480. 
Wooster and Joseph Spencer, of Connecticut; and Nathanael Greene, of Rhode Island. Geographical and political, as well as military considerations, controlled these The Brigadierselections. The youngest of them, Greene, then thirtythree years old, was without military experience, but was destined to become the most famous soldier, after Washington, of the Revolution. He was at Boston in command of the Rhode Island "army" of three regiments. Pomeroy, Wooster and Spencer were between sixty and seventy years old, veterans of former wars. Pomeroy declined his appointment, being dissatisfied that Putnam should be chosen over his head to be a major-general; but a year later he went out with the militia to the Hudson River, and died there of sickness contracted in camp. Wooster served for a while in Canada, but was considered inactive and inefficient, and resigned. He also went out with the militia in the following year, and was mortally wounded in a skirmish near Danbury, Conn. Spencer's service was inconspicuous, and he resigned in the spring of 1778 to go to Congress. Thomas was also a veteran. He rendered good service at Boston, and after Montgomery's death was sent to command the troops in Canada, and died there in 1776. Montgomery, Sullivan and Heath were all under forty years of age when they received their appointments. Montgomery had been an officer in the British army, had fought under Wolfe, and had resigned and emigrated to America three years before. He was a splendid soldier, and his death, in the assault on Quebec, in the first year of the war, was a great loss. Sullivan and Heath were too young to have served in the previous wars, and had no military experience when appointed. But they soon learned their trade, and rendered good service throughout the war. 
1775 At the same time that these appointments were made, The Adjutant- Horatio Gates, of Virginia, was appointed adjutantGeneral. general. He also had been an officer in the British army, had served with Braddock, and on the conclusion of the last war had settled in Virginia. He intrigued Schuyler out of his command, received the surrender of Burgoyne after Arnold had done all the hard work, tried without success to displace Washington, made a complete failure of his Southern campaign and then disappeared from The Quarter- public life. Mifflin, of Pennsylvania, who accompanied master-General.

Washington to Cambridge, was made quartermastergeneral. He was thirty-one years old, a merchant in Philadelphia, and successful in politics, both before and after the Revolution. But he was not a soldier, was a failure as quartermaster-general and joined Gates in his intrigues against Washington.

On the whole, remembering that the Colonies at the beginning of the Revolution had no military organization, these first appointments to the chief places in the army were very judicious. Excepting Lee, who had no standing except such as was created by his own gasconade, all were men of importance in their respective communities, and eleven of the fifteen had been in active campaigns as regulars or volunteers. Two of them-the commander-in-chief and the youngest brigadier-were destined to place their names forever in the list of great soldiers; and it is pleasing to remember that from the day they first met at Boston there was never jealousy, discord or ill feeling between them, but always loyalty, friendship and sympathy, growing ever stronger and firmer until the death of Greene eleven years later.

Arrival of Washington, July 10
Washington arrived at Cambridge on July 3, inspected the troops, examined the lines and made his report to 
Congress. The army numbered 20,242 officers and men, of whom 17,215 were present for duty. There were 35 regiments, of which 26 were from Massachusetts and 3 The Continenfrom each of the other New England colonies. These men knew how to shoot, from long practice, but they had no other military knowledge; they were of high character, intensely patriotic, fiercely independent and extremely impatient of the restraints of discipline. Their terms of enlistment would all expire within six months. Powder was extremely scarce, there were only a few pieces of artillery, there was no cavalry and hardly any organized supply departments. The fortified lines, previously described, were only partially constructed.

For the next eight months Washington's task was to organize this army; to replace it, within cannon-shot of the enemy, by another army, when the enlistments expired at the end of the year; to extend and complete his fortifications; to be prepared at every moment to repel an attack by the British should Howe decide, as every one supposed he would, to venture forth from Boston. Public opinion, ignorant of the difficulties with which he was surrounded, demanded that Washington attack Boston; and he himself shared the longing to do so. Four times Washington called his generals, Ward, Lee, sept. 11 Putnam, Thomas, Heath, Sullivan, Spencer, Greene and oct. 18 Gates, in council of war, and submitted the question whether Boston should be attacked, and each time in 1776 such a manner as to suggest an affirmative answer. But Jan. 16 each time they advised, unanimously, against it. There Feb. 16 can be no question that their advice was judicious.

Finally, however, in March-when Washington had enlisted and organized a new army, and had procured the temporary services of ten regiments of militia; when 
1776 Knox had dragged the heavy cannon through the snow from Ticonderoga; when the privateers had captured an abundance of powder from the incoming British supply ships; when the fortifications were completed so as to furnish rallying-points in case of defeat-the time for taking the offensive under favorable conditions had arrived, and Washington eagerly seized the opportunity.

His plan was to send Thomas with 2,000 men, supplied with intrenching tools, fascines, etc., from the Roxbury lines to seize and fortify Dorchester Heights-what is now

Seizure of Dorchester Heights

March 2 March 3 March 4 called Telegraph Hill, in Thomas Park, South Boston. These heights, at an elevation of about ninety feet, commanded the channel and the south-eastern side of Boston. If occupied, with the large guns from Ticonderoga, they made Boston and its connections with the sea untenable. Howe knew this, and had long contemplated an attempt to seize these heights. That he did not venture during all the long months of the siege to put his thought into execution shows the paralysis which had been inflicted upon him and his troops by the losses at Bunker Hill. The movement was carried out exactly as planned. For two nights the batteries at Cobble Hill, Lechmere's Point and Roxbury kept up a furious cannonade against the British lines, and on the third night, about 8 o'clock, Thomas moved out, occupied the Dorchester Heights, and under protection of advanced guards sent out toward Nook's Hill and Dorcheśter Point to protect him against possible attack from Boston or Castle Island, his men under Gridley's direction dug up the frozen ground, and before daylight had finished two very substantial redoubts. Howe was amazed. He wrote to Lord Dartmouth that it must have required the work of 12,000 men (the fatigue party in fact numbered 800), and is said to have remarked 
that his whole army could not have done as much in a 1776 month. But the forts were there, and his only alternative was to attack and capture them or to evacuate Boston. He immediately decided on the former, and asBritish Plan for Countersembled 2,400 men, under Earl Percy, to embark in transports, rendezvous near Castle Island, and the next night attack the Dorchester Heights from the east. His preparations were plainly visible from the heights where Washington had gone in person. To meet them Washington ordered a reinforcement of 2,000 men for Thomas, and simultaneously assembled 2 brigades at Cambridge, about 2,000 men each, carefully selected, under Sullivan and Greene, and ordered them to embark in boats which had been previously collected in the Charles River, cross the back bay, force their way through Boston to the works at Boston Neck, which were too strong to be assaulted in front, attack them from the rear, open the gates and let in the troops from Roxbury. But a furious gale came up during the afternoon and continued through the night and the next day, so that neither plan could be carried out, and Percy's troops returned to Boston. Howe then decided to evacuate the town. Ten days elapsed, howMarch 5 Evacuation of Boston ever, before the embarkation was complete. In the meantime, Washington kept up an almost constant cannonade from all his batteries, strengthened his works on Dorchester Heights, and after several unsuccessful at- March 16 tempts, finally succeeded in building batteries on the north-eastern side of the Dorchester peninsula, and also on Nook's Hill, nearly a mile nearer to Boston than Dorchester Heights. The next morning Howe completed his March 17 embarkation, and accompanied by the men-of-war his transports dropped down to Nantasket Roads, and a few days later sailed for Halifax. Washington's troops 
1776 entered Boston by Charlestown Neck and Boston Neck within a few hours after Howe had embarked.

Howe took away with him about 11,000 soldiers and seamen and 1,000 loyalist refugees. He left behind a prodigious amount of supplies and military stores of all kinds, in excellent condition and most welcome to Washington's straitened army; he threw most of his powder into the bay, and he abandoned 159 cannon, most of which had been rendered useless by spiking or breaking the trunnions. Washington's force, as shown by his morning report of March 9, numbered 1,254 officers and 15,767 men present for duty in the infantry regiments, 640 in the artillery and 6,838 in the Massachusetts militia. He returned the militia to their homes and ordered five regiments to march for New York the day after he entered Boston. The rest of the army, except five regiments left as a garrison under General Ward, followed as soon as the British fleet left Nantasket Roads. Wash-

April 4

Results of First Year of the War ington himself started for the same point in less than three weeks after the evacuation.

The first year of the war (less one month) had thus terminated. It had the same characteristics as the succeeding years. On the one side were the best regular troops of Europe, commanded and led by generals of wide experience and personal courage, but of not more than average ability, well equipped and supplied from the ample resources of a wealthy nation, whose animating motives were a sense of duty, allegiance to the king and contempt for what they called the rustic rabble which had broken out in rebellion. On the other side was an irregular force, enlisted for a short period and constantly changing, without military training or discipline, without arsenals, factories or depots of supplies, 


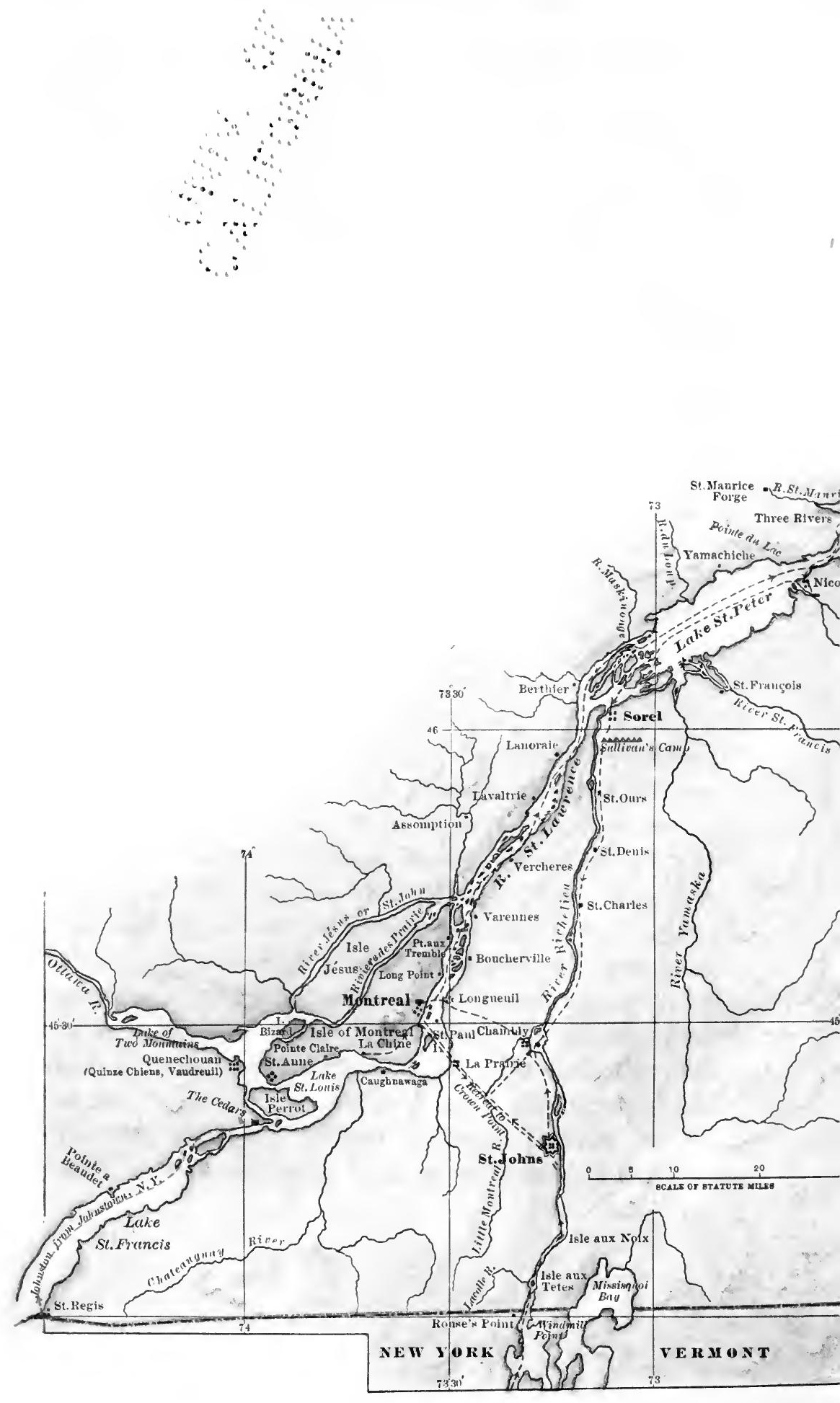


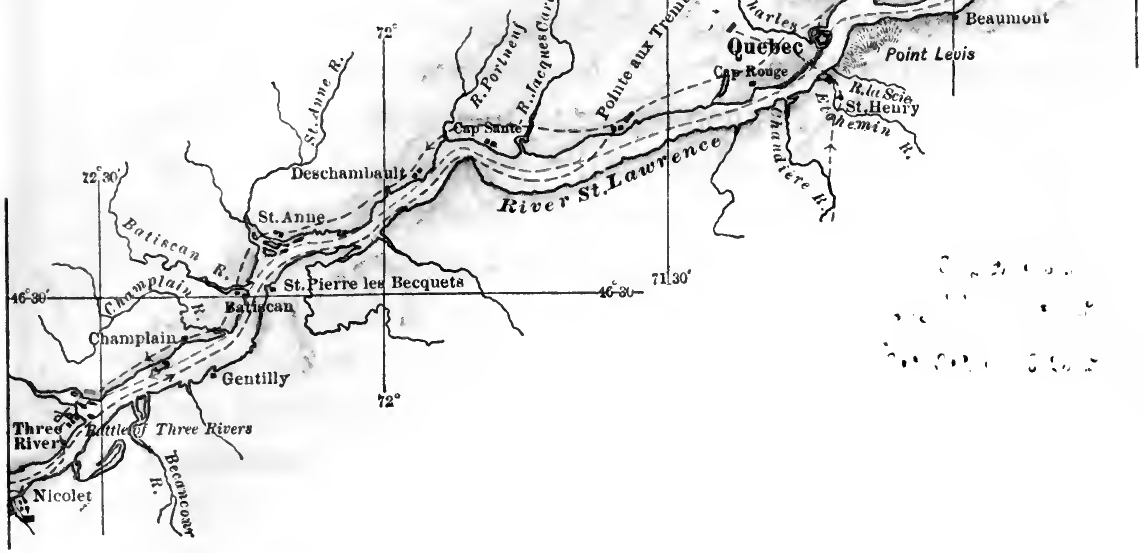

Courtesy of The Burrows Brothers Conpany, Publishers, Cleveland, Ohio From Avery's History of The United States and Its People 


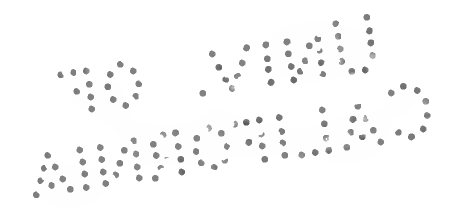


and without money or financial credit; but animated with a fiery passion for liberty, a profound belief in the righteousness of their cause and a firm determination to redress their grievances at any sacrifice; commanded by a soldier and statesman of lofty character, inflexible in purpose yet diplomatic in argument and free from anything like intolerance, with varied military experience and military instincts and ability of the highest order, capable of pursuing a Fabian policy with infinite patience so long as conditions imposed it, and then striking with extraordinary rapidity and sagacity when the conditions were favorable for the offensive; gaining and holding the confidence of his followers in an almost unrivalled degree.

What one side lacked, the other possessed. The odds were about even, and the contest was not unequal. It took eight long years to decide it, of which nearly seven were filled with active hostilities.

The operations at Boston were not the only military events of the first year. A daring offensive campaign had been carried on in Canada. Benedict Arnold, whose career ended in infamy but whose military ability, energy and reckless daring cannot be denied, had written from Ticonderoga to the Continental Congress, ${ }^{1}$ suggesting say 23 an invasion of Canada; to which Congress responded by requesting Governor Trumbull, of Connecticut, to appoint "a person in whom he can confide" ${ }^{2}$ to command at Ticonderoga, and by passing a resolution that no expedi-

${ }^{1}$ In J. N. Arnold's Life of Benedict Arnold and in Justin H. Smith's Arnold's March to Quebec there are voluminous references to and extracts from journals and other original documents; so that no reference is necessary for the next six pages further than to say that the statements of facts herein made are founded on those documents.

2 Jour. Cont. Cong., II, 74. 
tion ought to be made into Canada. But shortly Congress changed its mind in consequence of news that the tory governor of New York was trying to engage the Indians in the Mohawk Valley to attack the posts on Lake Champlain. Congress thereupon appointed Schuyler to

June 27

July 18

July 31

Aug. 17

Arnold's Plan

Sept. 5 command the Northern army, ${ }^{1}$ to take personal command at Ticonderoga and to invade Canada, if practicable "and not disagreeable to the Canadians." Schuyler proceeded to Ticonderoga. His own colony was dilatory in raising troops, but he found there 1,352 men, mostly from Connecticut, under command of Colonel Hinman. They were as deficient in every military requirement as those at Cambridge. But Schuyler began immediately the construction of boats and advised Washington of his intention to cross the lake and invade Canada. Montgomery reported to him as second in command, and by the end of August the expedition was ready to start.

Meanwhile Arnold had returned to Cambridge and had laid before Washington a plan to invade Canada by way. of the Maine wilderness and capture Quebec by surprise. It was a most daring-almost foolhardy-project. Yet it came astonishingly near to success. Arnold had learned that in all Canada there was only one regiment, and the greater part of this was with Governor Carleton at or near Montreal. Quebec was entirely undefended. Washington carefully considered the project, and finally adopted it and gave detailed instructions for the conduct of it. ${ }^{2}$ A detachment was made up for Arnold of 1,050 men, infantry from New England and riflemen from Pennsylvania and Virginia, all selected for their knowledge of woodcraft, and none ordered except those who had volunteered. Among the officers were Christopher

${ }^{1}$ Jour. Cont. Cong., II, $109 . \quad$ 2 Dawson, 113-115. 


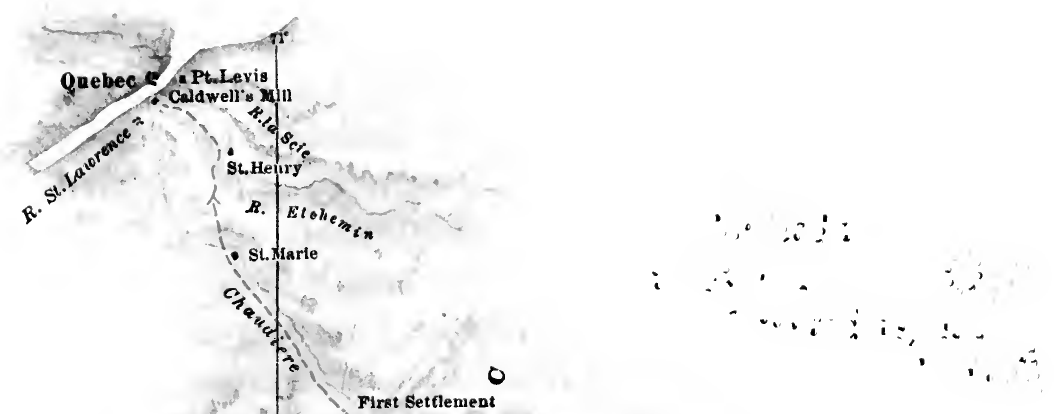

S E $A$ T 1 G A

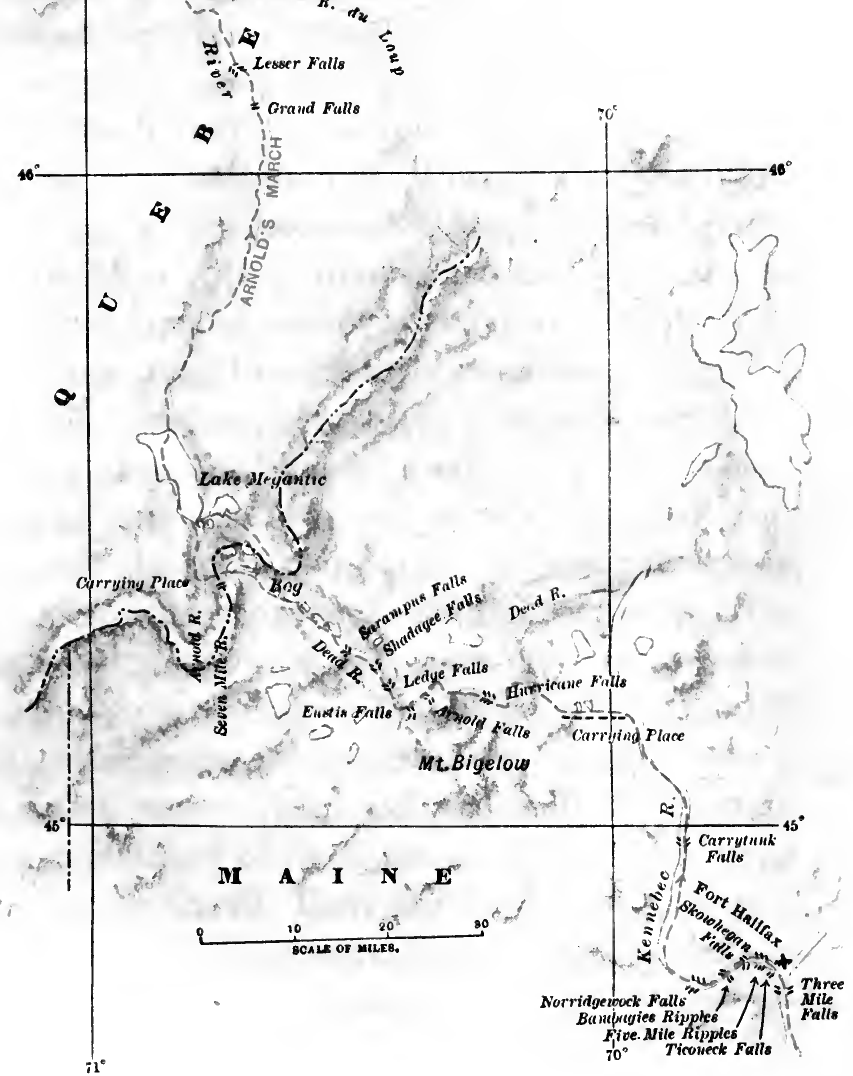




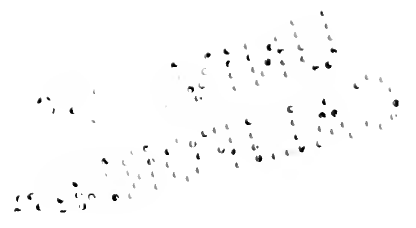


Greene, Daniel Morgan, Aaron Burr and Henry Dearborn. The expedition marched from Cambridge to Newbury- sept. 11 port, there embarked in ten small transports, sailed to the Kennebec and up that river almost to Bath, disembarked and, provided with 200 boats for the portages, plunged into the wilderness.

At that date Schuyler was confined to his bed in Ticon- Sept. 25 deroga with a bilious fever, but the expedition under schuyler's Montgomery, about 1,200 men and four 12-pounders, had crossed Lake Champlain, descended the Sorel (or Richelieu) Movement from TiconRiver and laid siege to St.John, a fortified town garrisoned sept. 1 by a portion of the 26th Regiment under Major Preston. ${ }^{1}$ While the siege was in progress Montgomery was reinforced by several hundred men from New Hampshire and New York and by a battalion of Canadian patriots under command of his wife's kinsman, Colonel James Livingston. Ethan Allen with a small force was sent to gain recruits in Canada, and while so engaged undertook to capture Montreal. In the skirmish which resulted, Allen and about half his party were taken prisoners, and Allen Sept. 25 himself put in irons and sent to England. A little later another expedition was sent out which captured Fort oct. 18 Chambly, lower down on the Sorel, with its garrison of 168 men; among the spoils were six tons of powder, the most valuable commodity on the continent. A few weeks later St. John surrendered, with 400 regulars and 100 Nov. 3 Canadians. Montgomery immediately pressed on to Capture of Montreal, which was without defence, and was surrenMontreal dered by a committee of its citizens; Carleton escaping Nov. 12 in a small boat on the St. Lawrence to Quebec.

On the day that St. John surrendered Arnold was about

1 See Operations in Canada. Appendix to Sparks's Letters, I, 460-549. This contains the official reports and correspondence of Schuyler, Arnold, Montgomery, Wooster, Sullivan and Gates. 
177530 miles from Quebec, after a march of incredible

Arnold's March through the Wilderness

Oct. 13

Nov. 10

Nov. 13

Arnold

Arrives at Quebec

Nov. 19 hardships and hunger through 200 miles of what is still a mountain wilderness, the best hunting ground for big game east of the Rocky Mountains. He had sent a letter to Schuyler by an Indian, but the letter was given to Governor Carleton, who thus first learned of Arnold's approach, and immediately began to remove all the boats in the river so as to prevent Arnold's crossing. But Arnold pushed on and when he arrived at the river he collected canoes and dugouts, and although delayed three days by a severe gale and by the presence of a frigate and a sloop of war, he succeeded in crossing on the fourth night; and landing at the same place where Wolfe had landed sixteen years before, he climbed the cliffs to the Plains of Abraham and marched toward the western gates of the city. He had about 650 half-naked men, the rest having perished in the wilderness; and they had barely 400 unbroken muskets between them, and five rounds of ammunition. Arnold promptly demanded the surrender of the city; but he was in no condition to enforce his demand, for the place was strongly fortified, had an abundance of heavy guns and was garrisoned by about 1,900 men, regulars, irregulars and seamen, who had within ten days been gathered for its defence. Had Arnold arrived two weeks earlier, or had his letter to Schuyler not been delivered to Carleton, it is quite possible he would have surprised and captured the place. Situated as he was, there was nothing to do but fall back about twenty miles, up the river, to Point aux Trembles, and await the arrival of Montgomery, to whom he had already written.

When Montgomery received his letter he made instant preparation to march to his assistance. After leaving 


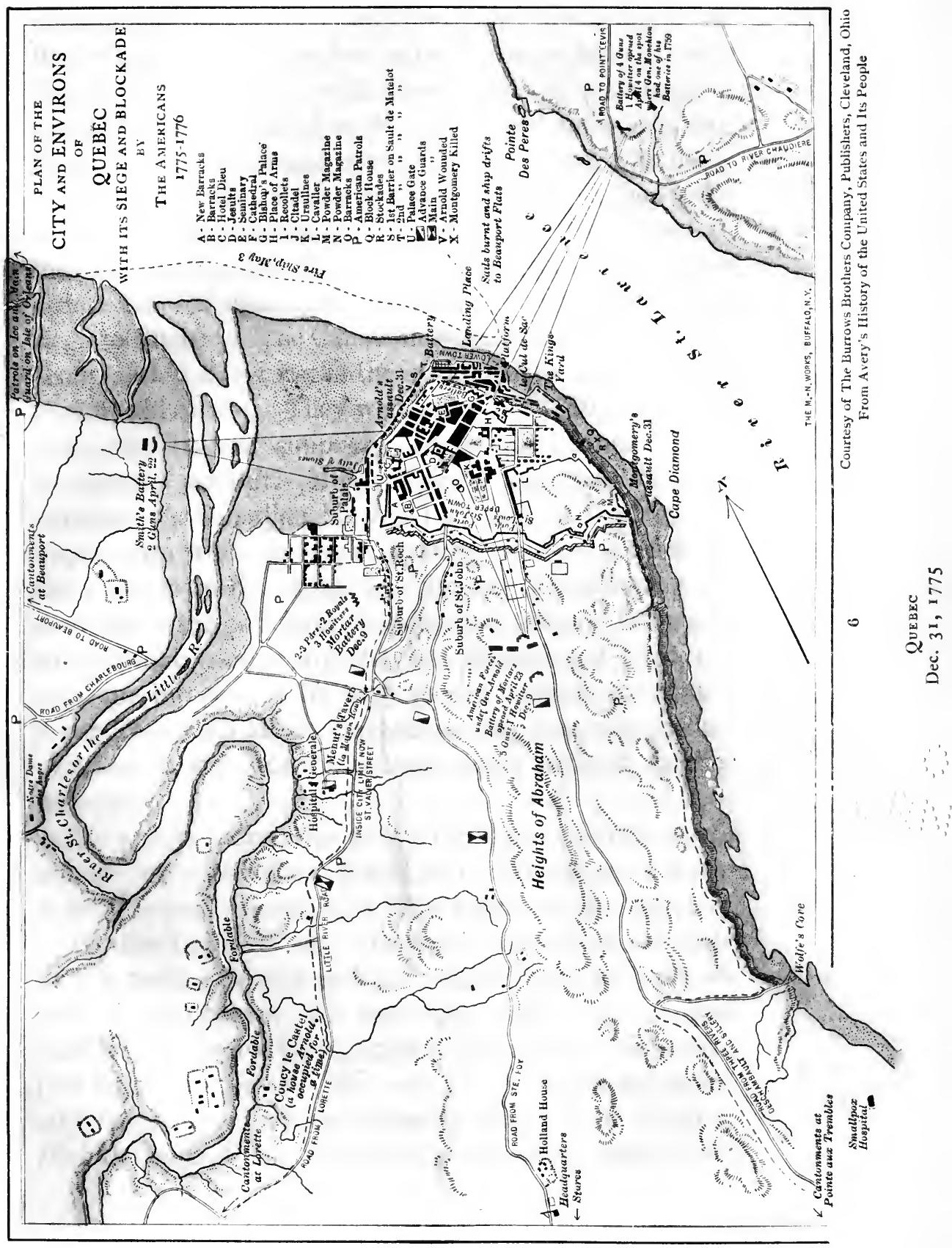


detachments at St. John and Montreal, and sending home men whose enlistments had expired, he could only take 300 men with him, but with these he set out in transports Nov. 24 which he had captured at Montreal, and made his way Dec. 3 down the river, joining Arnold at Point aux Trembles, Montgomery and handing over for his ragged and half-clothed men a year's supply of clothing which he had found in the military depots at Montreal. Their combined forces numbered less than 1,000 men, but they forthwith laid siege to Quebec. The Canadian winter was already upon them, and in a few weeks the enlistment of most of their men would expire. They were more than 300 miles from their own base of supplies. Their only chance was in a vigorous assault. Montgomery's plan was to send Livingston's Canadian battalion to make a feint on the upper town while the main assaults were to be made on the lower town by Arnold and himself; he following the road under the cliff from Wolfe's Cove to Cape Diamond, and Arnold coming by the St. Roque road from the opposite direction. If they gained possession of the lower town with all its magazines, they hoped to induce Carleton to surrender the upper town without further resistance.

The troops moved out at 2 o'clock on a winter morn- Dec. 31 ing, the weather intensely cold and a driving snow-storm in their faces. On reaching Cape Diamond, Montgomery at the head of sixty men attempted to carry a stockade with a rush. He was instantly killed, together with his aide and ten others; the rest of his party fled. Arnold Assault on Quebec reached the Palace Gate, on the other side of the town, just before daybreak. He, too, led the storming party, and fell at the first fire, severely wounded in the leg. Had the wound only been mortal, his name would have 
1775

gone down in history side by side with that of Wolfe and Montgomery, instead of being forever the synonym of treason. Morgan, with the main body, was close behind Arnold, but in the narrow, crooked streets his retreat was cut off and he was compelled to surrender with 426 men. The remnants of the two columns made their way back to camp.

Arnold was carried to a hospital, from which he directed the command of the few hundred men still left to him, but he wrote to Schuyler for reinforcements and he ordered no retreat; nor did Carleton attack him while his little band remained shivering in their camp to the west of the city. The reinforcements arrived three months later, and with them General Wooster, who assumed command. A sort of siege was undertaken, but it was not effective.

May 1 He was soon superseded by General Thomas. And then reinforcements began to arrive for the garrison-the first detachment of the British and Hessians who had just arrived from Europe under command of Burgoyne.

Retreat from Quebec

May 30

June 7

July 1

Thomas raised the siege and retreated to the Sorel, (Richelieu), marching up its banks to Chambly, where he died of small-pox. General Sullivan, who had already been ordered to supersede Thomas, arrived a few days later. Reinforcements brought his strength up to 2,500 men, and he made an attack on Three Rivers, but was defeated. Sullivan's army numbered 5,000 on paper, but less than half that number fit for duty; they were completely discouraged and demoralized, "the small-pox, famine and disorder had rendered them almost lifeless." Burgoyne, who had commanded in person at Three Rivers, was daily receiving reinforcements. There was no alternative for Sullivan but a hasty retreat, and he brought the remnants of his force to St. John and Isle- 
aux-Noix, and thence across Lake Champlain to Crown 1776 Point, where Montgomery had set forth just ten months before.

In the lack of proper returns and the disorder of the retreat, it is impossible to say just how many men were Results of the Expedition sent on this expedition, and how many were lost. But it appears that from first to last not less than 8,000 men served in Canada, and barely 3,000 returned fit for duty. It was a bold expedition, possibly beyond the resources of the Colonies at that period; but Washington considered it with the utmost care, gave it his full approval and felt confident of its success. And Montgomery and Arnold showed, in its earlier stages, how apparently insurmountable difficulties can be overcome by a judicious combination of skill, energy and daring. Had Montgomery lived, or had Arnold been left in command when the reinforcements came to Quebec in April, perhaps it might have succeeded. But the generals who were sent in succession to take command, Wooster, Thomas and Sullivan, were none of them equal to an enterprise of this character. ${ }^{1}$ Had it succeeded, it would probably have united Canada to the Thirteen Colonies, and changed the whole course and outcome of the war.

${ }^{1}$ See the interesting analysis of Sullivan's character in Washington's letter of 17 June, 1776, to the President of Congress. Sparks, III, 426; IV, 364 . 


\section{CHAPTER II}

\section{NEW YORK}

1776

British Plans for Carrying on the War

1775

Oct. 26

1776 Jan. 9

The Hessians

THE war had begun in an attempt, from the British stand-point, to put down a local insurrection in Massachusetts; but when the news of Bunker Hill and the siege of Boston reached London, it was evident that there were thirteen colonies to subdue, occupying more than a thousand miles of sea-coast, and a hundred miles or more into the interior. To carry out this subjugation more men were needed and a more comprehensive plan for their operation.

Parliament had provided in December, 1774, for an army of only 18,000 men, ${ }^{1}$ and when it met in the following year more than two-thirds of this force was cooped up in Boston. It now provided for 12,000 additional seamen and an army of 55,000 men. ${ }^{2}$ But as this largely increased force could not be raised immediately, and as allies were not to be had, George III and his ministers arranged to buy soldiers for cash. Treaties were made with the Duke of Brunswick, the Landgrave of HesseCassel and other petty German rulers by which they undertook to furnish a large body of troops, to serve under their own officers in America. For each soldier killed England was to pay \$35, and for each wounded, $\$ 12$; England was also to pay all expenses of every character, and in addition to pay to the Landgrave personally $\$ 550,000$ per annum, and to the other princes in propor-

${ }^{1}$ Amer. Archives, 4, I, 1479.

${ }^{2}$ Ibid., 4, VI, 143. 


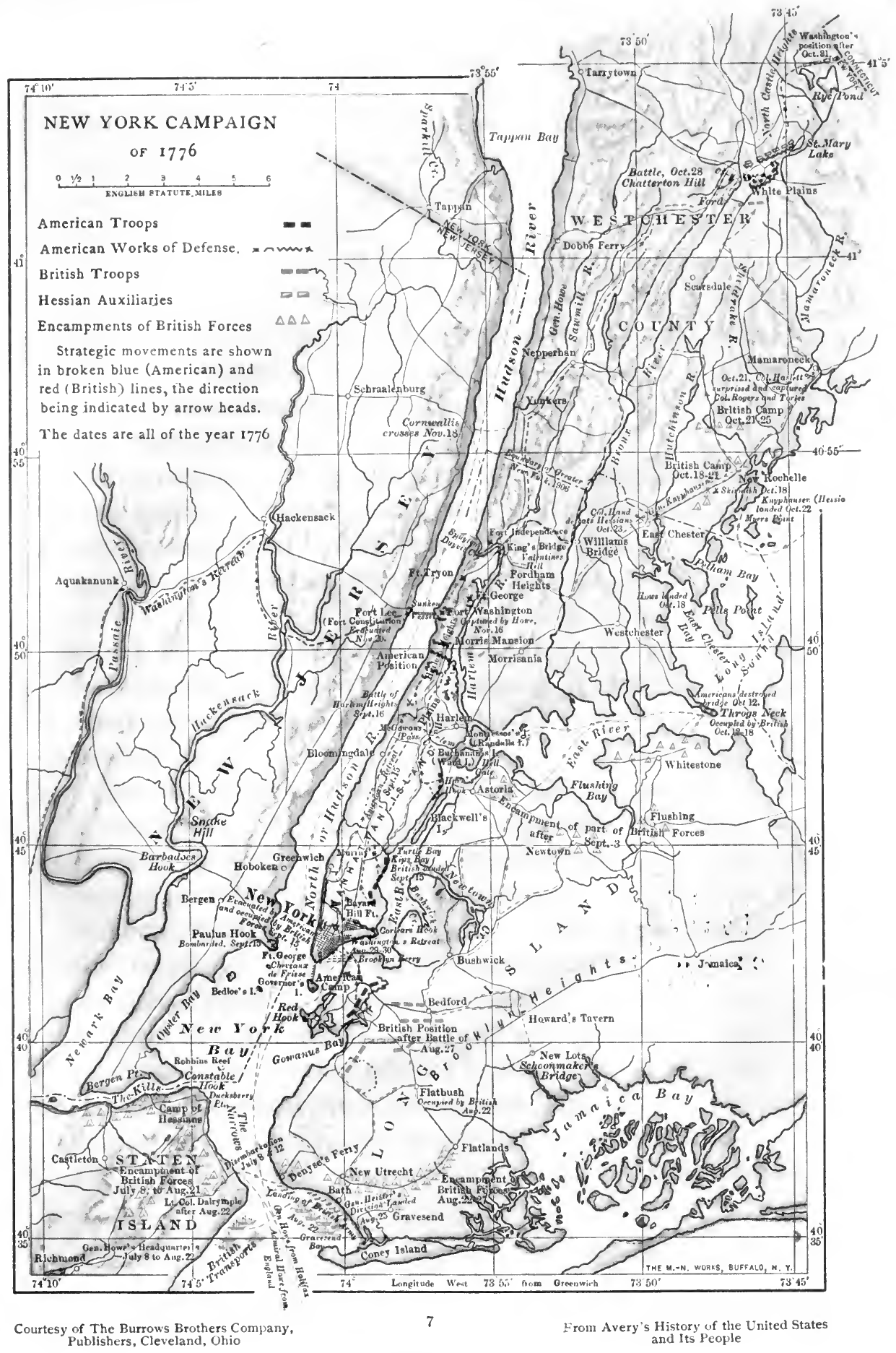

New YorK

April-Nov., $17-6$ 

tion. While the employment of mercenaries was an ancient practice, yet there were special features in these treaties $^{1}$ which made this bargain quite unique in its infamy and degradation. The number of such troops sent to America was 29,867 , of whom about 1,200 were killed or mortally wounded, 6,354 died of other causes, 5,000 deserted, and 17,313 returned to their homes nearly eight years later." About 60 per cent came from Hesse, and these mercenaries were thus known under the general name of Hessians.

The last of the 6 treaties relating to these transactions was ratified by Parliament and the first contingent, numbering about 17,000 men, together with 7 British regiments, were ready to sail early in the year, and more were to be ready in the spring. A British regiment at Feb. 5 that time consisted of 2 battalions, 12 companies, about 50 officers and 672 men. One company in each battalion remained at home, and a regiment took something under 600 men to America.

The preparations, were thus made to send out about 20 regiments or 12,000 men from England, and 17,000 Hessians, which, added to the 19 regiments that Howe British Foree for the New had at Boston and the 3 in Canada, would make a force of about 42,000 men-which was thought to be ample for the purpose. The first detachment under Burgoyne (who had gone to England on leave in December) arrived in the St. Lawrence in April, and pushing its way through the ice reached Quebec in time to drive back the Americans there under Sullivan, as we have seen. ${ }^{3}$

In preparing a plan for the operation of their troops, the British generals were mindful of the topographical

${ }^{1}$ Printed in full, Amer. Archives, 4, VI, 271-278.

${ }^{2}$ Lowell, 20, 300.

${ }^{3}$ Ante, p. 26. 
1776 features of the Atlantic seaboard, which had already determined the line of military operations during the wars with the French while the latter still possessed Canada. The valley of the Hudson and the northern lakes pierces the range of mountains which extends from New Hampshire to Georgia, and affords a natural lowgrade line of communication from Montreal to New York. The Hudson played the same part in the Revolution as the Mississippi in the Civil War. If the British could take and hold this line it would cut off New England from the other colonies. In the former the war had its origin and its most ardent supporters; in the latter were threefourths of the population and the seat of government. While New York itself did not then possess the relative importance it now has-the colony being seventh in population and the city being exceeded in the number of its inhabitants by Philadelphia, and almost equalled by Boston $^{1}$-yet the harbor was unrivalled, the river was navigable for the ships of the day almost to Albany, and Great Britain had complete control of the sea, the incipient American navy consisting only of a few small privateers. Howe and Burgoyne had long resented the humiliation of being shut up in Boston, which was not easy of defence and whence no offensive movements could be undertaken to advantage. They desired to transfer the seat of war to New York, capture that city, and seize and hold the line of the Hudson. The new campaign was planned on that basis.

The British did not follow out this general plan, of the soundness of which there can be no question, but allowed themselves, as we did later in the Civil War, to be drawn into diversions, in the hope of restoring their authority

${ }^{1}$ A Century's Growth of Population. Census Bureau, 1909, pp. 9-11. 
in certain localities, forgetting that the way to gain solid results in war is to destroy the opposing army and not merely to occupy territory. They thus planned a side side Issues issue against Charleston, in South Carolina, where Clinton had been sent with 2,000 men from Boston and where he 1775 was to be joined by a reinforcement of 7 regiments under Dec. 16 Cornwallis, convoyed by a fleet under Admiral Parker. ${ }^{1}$ Similarly, the imminent danger in Canada led to sending Burgoyne to reinforce Carleton at Quebec. Clinton failed at Charleston and then joined Howe at New York. Burgoyne, however, instead of reinforcing Howe and thus concentrating a force of such strength as would crush all opposition, moved on along an eccentric line to Montreal, and in the following year crossed Lake Champlain to Ticonderoga, intending thence to move down the Hudson. He could not act in concert with Howe, being separated from him by hundreds of miles of wilderness. The result of acting on such widely divergent lines, instead of concentrating every available man at New York, was that Burgoyne lost his entire army.

On his way to Charleston, Clinton had stopped at New York, and as soon as Washington heard of this he sent Lee to collect such militia as he could in Connecticut, New York and New Jersey and organize the defence of Movement of the American Army to New York New York. ${ }^{2}$ A resolution of Congress ${ }^{4}$ then sent Lee to Jan. 8 command the newly formed Southern Department; but

${ }^{1}$ Post, p. 184.

${ }^{2}$ Two exhaustive monographs have been published by Prof. Henry P. Johnston of the New York City College, one on the campaign of 1776 around New York, having special reference to the battle of Long Island, and the other on the Battle of Harlem Heights. Like Frothingham's Boston and Arnold's March, they are filled with references to original documents and copies of a great many of them. These documents have been followed in this chapter and it seems unnecessary to make specific references.

${ }^{4}$ Jour. Cont. Cong., IV, 180. 
1776

Mar. 1

March 16 to April 13

Lee's Plan

April 29

May 12

Fortifications of New York

June 10

Washington soon arrived with his army, which had left Boston as soon as Howe's fleet had sailed from Nantasket Roads.

Lee had reported that the situation of New York, surrounded by deep water, afforded no possibility of defence against an enemy having complete command of the sea. His plan of defence was to build a few small batteries at salient points on North and East Rivers, but to concentrate the main defence in an intrenched camp on Brooklyn Heights, which commanded the navigation of the East River. Washington approved this plan, and ordered Greene's brigade to occupy these heights and the brigades of Heath, Spencer and Stirling to be stationed just outside of what then constituted the city of New York, viz., from the Battery to St. Paul's Church. These positions were taken up early in May and all hands worked hard to complete the fortifications. After deducting the 5 regiments left in Boston and 16 sent to Canada, Washington had only 19 left for New York. Their returns showed a strength of 589 officers and 9,963 men, of whom 7,952 were present for duty. ${ }^{1}$

The plans of the fortifications were somewhat modified and enlarged after Washington's arrival, and their construction was carried out and the guns placed in them under direction of Colonel Henry Knox, who had been Gridley's assistant at Boston and now commanded the Regiment of Artillery. As finally completed the works consisted of no less than 21 redoubts with 121 guns, onequarter of which were 32-pounders (the largest siege-gun then in use) and one-half larger than 9-pounders. These guns had come from Ticonderoga, from Boston, from the Bahamas (where they had been captured by Commodore ${ }^{1}$ Sparks, III, 493. 
Ezek Hopkins) and from the gun foundries in various 1776 colonies. While Congress had erroneous views about the length of enlistment and the organization of armies, it displayed extraordinary energy in the manufacture of cannon, small-arms and powder.

The two works on Governor's Island and Red Hook, with 12 guns, guarded the approach from the Bay to the East River. A battery on Paulus Hook, with 8 guns, was intended to protect the Jersey shore of the North River. On Manhattan Island there were 11 redoubts, with 79 guns, situated on slight eminences adjacent to the water, from the vicinity of Chambers Street around the Battery and up the East River to 86th Street opposite Hell Gate. On Long Island, in front of Brooklyn (then a hamlet of a dozen houses, just east of the present Borough Hall), there were 7 redoubts, mounting 29 guns, stretching across the ridge which extends from Greenwood Cemetery to the Brooklyn Reservoir, and which at the point fortified was about a mile in width between the swamps of Wallabout Bay on the north and Gowanus Creek on the south.

The first squadron of the British fleet arrived from Halifax, bringing Howe and his Boston troops; next came Clinton and Cornwallis, who had been defeated at Charleston; and finally Lord Howe, the naval commanderin-chief, with the Hessians, and the Household troops from London. It was an imposing array, more than 400 transports and 32,000 soldiers the largest expedition that England had ever sent abroad; convoyed by 10 lineof-battle ships and 20 frigates, manned by more than 10,000 seamen, and armed with about 1,200 guns, many of them 64-pounders and 74-pounders, which completely outclassed the guns which had been collected with so much difficulty by Knox.

Arrival of the

British Fleet

July 3

Aug. 1

Aug. 12 
As the successive detachments arrived they went into camp on Staten Island just inside the Narrows. Washington viewed their arrival with no little anxiety; which was increased when two of the men-of-war sailed up the North River, under a furious cannonade which failed either to stop them or do them any serious damage. These ships anchored in the broad Tappan Zee, forty miles above New York, thus cutting off all communication by water with the Northern army. ${ }^{1}$ His position was indeed precarious. Heroic efforts had been made to increase his force. Sullivan had brought back his Continental regiments, or what was left of them, from Ticonderoga, and Congress had passed a resolution calling out 13,800 militia for the defence of New York. ${ }^{2}$ By the returns at the end of August, ${ }^{3}$ Washington had 25 regiments of Continentals and parts of 75 regiments of militia, with a paper strength of 33,363 , of whom there were "present fit for duty" 20,328. Opposed to these hastily collected and untrained troops was the greater part of the military and naval force of England, supplemented by all the mercenaries that it could hire.

Washington, however, did not lose confidence. He issued an impassioned address to his troops, ${ }^{4}$ telling them that "the fate of unborn millions will now depend, under God, on the courage and conduct of this army," and called upon them to "resolve to conquer or die"; and he disposed his troops to the best advantage. They were divided into five divisions under Putnam, Heath, Spencer, Sullivan and Greene (all of whom were now major-generals); and, as the enemy had complete command of the

${ }^{1}$ Sparks, III, 469, 475.

2 Jour. Cont. Cong., IV, 412.

'Sparks, III, 493; Amer. Archives, 5, II, 450, 451.

4 Sparks, III, 449. 
water and could choose his point of landing, three divisions 1776 were stationed near the southern part of Manhattan Island, one in the northern part from Fort Washington to Kingsbridge, and one on Long Island. Greene commanded the latter, and for four months had not only directed the construction of the redoubts, but had reconnoitred every foot of the ground by which they could be approached, and had compelled strict discipline and vigilance on the part of his troops. Unfortunately, early in August he succumbed to the malarial fever, with which so many of his men were prostrated, contracted in the swamps of Wallabout and Gowanus, adjacent to his works. He endeavored to direct his command from his bed in camp, but finally, a few days before the battle, he was at the point of death, and had to be carried to a house on Manhattan Island. Sullivan was sent to take Greene's place, Aug. 20 and four days later, when it seemed probable that the aug. 24 attack would be made on the Long Island side, Putnam, the senior major-general, was sent to take command. Neither of these officers had an opportunity to become familiar with the situation before the attack was made.

It was made in overwhelming force. Under cover of the navy, Howe embarked 20,000 men and 40 pieces of Battle of Long Island artillery in small boats at Staten Island and landed them Aug. 22 on the beach of Gravesend Bay. It was eight miles from the Brooklyn lines, and Washington was in no position to prevent or hinder the movement. Howe then sent Cornwallis with the Guards and Hessians to the hamlet of Flatbush, just south of what is now Prospect Park, and at the foot of a long ridge, which beginning at the bay (near Greenwood Cemetery) extends, in a direction north of east, through Prospect Park to the Brooklyn Reservoir and many miles beyond. The rest of Howe's 
1776 troops were in rear and to the left of Cornwallis, and in this position they remained for three days; during which Howe received from the tory farmers of Long Island complete information as to Washington's position. On the other hand, Howe's inaction left Washington in doubt whether the landing on Staten Island might not be a feint with a part of his troops, whereas the main landing might be on Manhattan. Washington, however, each day sent reinforcements to Long Island, in all 10 regiments, bringing the strength up to about 7,000 men, or more than one-third of his effective force, and, as previously stated, sent Putnam to assume chief command. He examined the lines in person with Putnam, and on returning to his head-quarters wrote a sharp letter to the latter in regard to the lack of vigilance and discipline among the troops, but he did not give him specific instructions as to the placing of them. Washington's exact language was as follows:" "I would have you form proper lines of defence around your encampment and works on the most advantageous ground. . . . The wood next to Red Hook should be well attended to. . . . The militia . . . will do for the interior works, whilst your best men should at all hazards prevent the enemy's passing the wood and approaching your works. The woods should be secured by abatis where necessary, to make the enemy's approach as difficult as possible."

It is hardly possible that Washington intended to spread out his small force along the entire ridge, seven miles long, from the river road to Jamaica pass. Putnam, however, seems to have so understood it, although he gave no definite orders to carry such a plan into effect. He appears to have acquiesced in the dispositions made 


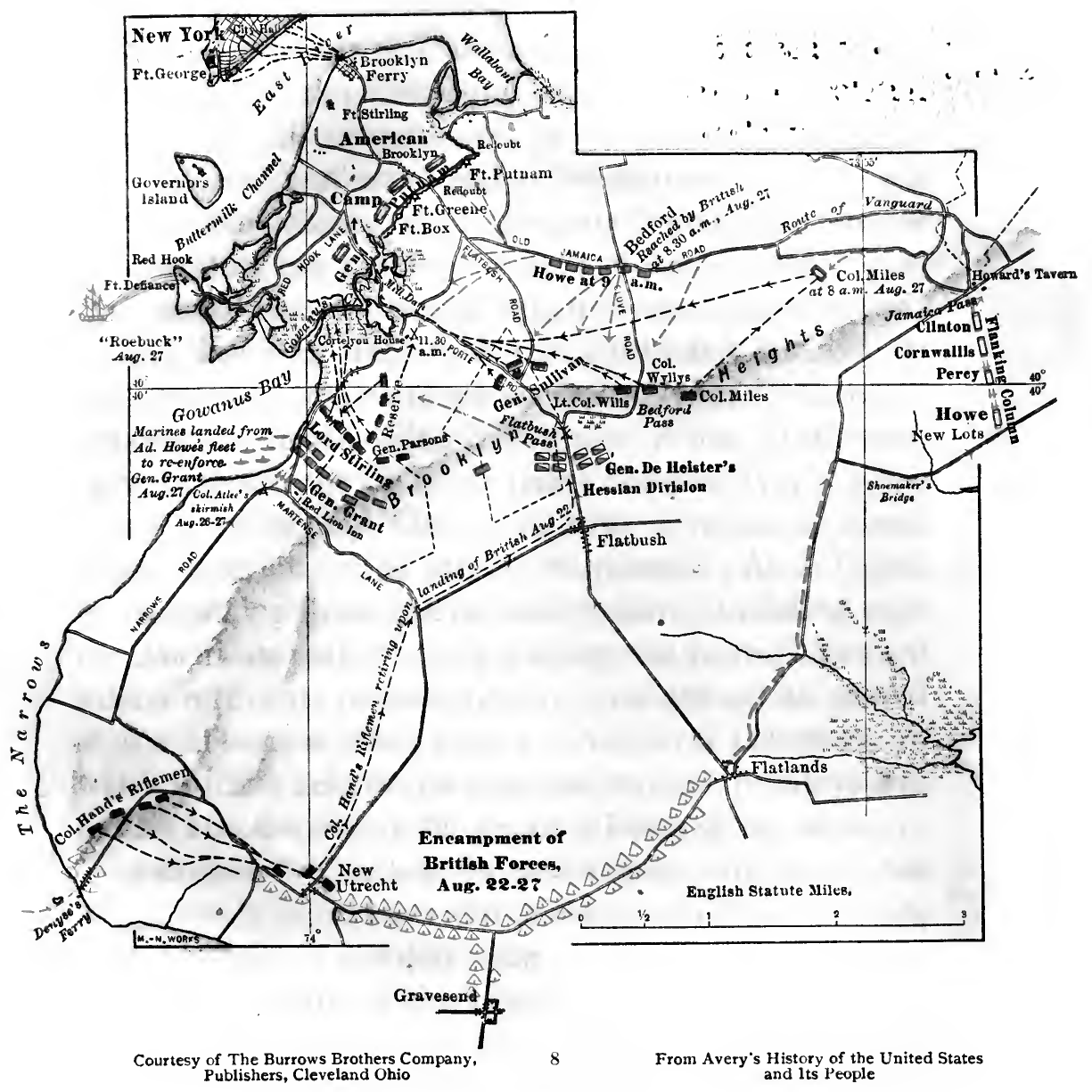

LoNg IsLAND

Aug. 27, 1776 
$\because \quad, \because \quad \because \because$

$\because 20, \cdots$

. $2 . \therefore \therefore$ 
in Sullivan's orders; 2 regiments "to possess the Flat1776 bush road," 2 others "to take possession of the Bedford road," and 2 others of "the road near the river." The Jamaica pass, five miles to the east of Flatbush, was not guarded.

Howe's plan was to make a feint along the coast road and in front of the Flatbush pass, while a turning column Howe's Plan of fully half his strength was to make a night march to the eastward and come in by the Jamaica pass, march west by the Jamaica road and come squarely in rear of all the American positions outside of their fortifications. The movement was carried out in accordance with this plan. Major-General Grant with 2 brigades, about 5,000 men, moved forward along the coast road; LieutenantGeneral de Heister with 3 brigades, about 6,000 men, moved toward the Flatbush pass (Prospect Park); while Battle of Long Island Clinton, Percy and Cornwallis with 5 brigades, about 10,000 men, made the turning movement. At 3 o'clock Aug. 27 in the morning Grant and de Heister were skirmishing with the American outposts and Stirling was hurried forward with 5 regiments to meet Grant. A sharp action ensued in the hills near what is now Greenwood Cemetery, in which Stirling held his own against superior numbers and inflicted on the enemy the greatest losses of the day.

As early as 9 o'clock in the morning the turning column was squarely in his rear, and in the rear of Sullivan, who, Howe's Flank with 6 regiments was defending the Flatbush pass against the feigned attack of the Hessians; and the head of the column was nearer the fortified lines and main camp of the Americans than either Sullivan or Stirling. This turning column - light dragoons, Guards, Highlanders, infantry regiments and ten pieces of artillery, in all 10,000 men, under Clinton, Cornwallis and Percy, with Howe 
1776 himself in personal command-had left Flatbush at 9 Aug. 26

Aug. 27 o'clock the night before, and piloted by tory guides, had marched to the east and then to the north, and before dawn had reached the Half Way House (Howard's Tavern) on the Jamaica road on the eastern side of the Jamaica pass (Atlantic and Vesta Avenues), about five miles from the American fortifications. The American army was absolutely without cavalry, and for such scouting and outpost duty as is usually performed by cavalry it had to rely upon small parties of officers who owned horses. Such a party, five in number, was observing this Jamaica pass. It was surrounded and captured by Clinton's dragoons about 3 o'clock in the morning. The Jamaica road (East Fulton Street) was thus open, and after resting his troops at the pass until daylight, Howe marched along that road, coming in the rear, first of Sullivan and then of Stirling, without warning. One regiment was posted nearly three miles out on Sullivan's left flank in the direction of the Jamaica pass, but it was in the woods and not on the road, and the British soon surrounded it and compelled the surrender of the colonel and most of his men, while the others scattered and escaped. The three regiments at the Bedford pass, about a mile to the left of Sullivan, 8.30 А.м. were next uncovered, and after a short skirmish began a hasty retreat toward the forts. The British moved more Aug. 27

Stirling's Heroic Attack quickly on the road than these fugitives in the woods, and Sullivan found himself attacked by Clinton in his rear and the Hessians in his front at the Flatbush pass (Prospect Park). He quickly ordered a retreat, which soon turned to a flight, and Sullivan himself was captured.

With all this firing on his left and rear, Stirling saw that his position was untenable. About 11 o'clock he started 
to retreat by the coast road to the Gowanus road and 1776 thence to the forts, but he had not gone far when he saw that he was surrounded. On his left were the Gowanus marshes, supposed to be impassable, on his right the main body of the British turning column, and squarely in front of him was Cornwallis with the Highlanders and the Second Battalion of the Guards. These were posted at the Cortelyou house on the Gowanus road where it climbs the hill skirting the Gowanus marsh (Third Street and Fifth Avenue).

Stirling promptly decided upon a heroic measure. He took Major Gist and part of the Maryland regiment and advanced to attack Cornwallis, ordering the rest of his five regiments to make their escape across the swamps and thus gain the forts. While Stirling and his handful of men kept up a stubborn fight for half an hour, or more, the greater part of his men did actually escape through the swamps, with only six or eight drowned. The Marylanders were finally driven back and dispersed, and Stirling himself was captured.

About this time Washington in person arrived at Cobble Hill, one of the forts. As soon as he heard of the action Arrival of Washington, he had ordered 6 regiments across from New York, but the mischief was done long before they could arrive. They began filing into the forts about noon, and by 2 o'clock in the afternoon the remnants of the 12 regiments that had been in the battle had succeeded in reaching these works. Inside the works were as many more regiments which had not been engaged. Howe's troops were fatigued with an all-night march and more or less fighting during a considerable part of the day. He had 20,000 men, less his losses; inside the works, about a mile long, with both flanks protected by swamps, were about 8,000 
Aug. 27 ,

3 P. M.,

Howe Decides not to Assault

Responsibility for the Defeat

men, half of whom had been in action and defeated. Should Howe assault the works? His men, it is said, were eager for it, and in his own report Howe says it required repeated orders to prevent it. If he succeeded in an assault, it is difficult to see how Washington's army, with a deep river at its back, could have escaped capture or dispersal. Howe says that he thought he would have succeeded, but would have sustained heavy loss; and he was satisfied that he would be able to gain the works, almost without loss, by siege operations. ${ }^{1}$ He therefore did not assault.

The battle was over. On the British side it was a brilliant victory, skilfully planned and well executed. On the American side it was a humiliating defeat. Who was responsible for it? Volumes have been written on this question, and it is not easy to answer it in a sentence.

In the first place, no one exercised general command. The part played by Putnam, the commanding general, was insignificant. Sullivan defended the pass, where he had gone as soon as he heard the firing, as long as it could be defended, but Putnam had arrived and superseded him in the chief command three days before, and it is unjust to hold Sullivan responsible for the conduct of the battle. ${ }^{2}$ Stirling had five regiments and fought splendidly with them, and there his responsibility ended. Putnam, in spite of his well-earned reputation for gallantry at Ticonderoga, eighteen years before, and later at Concord and Bunker Hill, did practically nothing as a commanding general; and Washington never again placed him in a position of high responsibility.

${ }^{1}$ Howe's Report; Dawson, 156; Howe's Narrative, 4, 5.

${ }^{2}$ Sparks, IV, 517, 518. 
Secondly, the American army was surprised, because it had no cavalry; and was attacked and outflanked by an army of regular troops of nearly three times its numbers.

Thirdly, Greene's illness was a terrible misfortune. He knew his troops and knew the ground, and (as he showed later on) he possessed extraordinary skill and resourcefulness in similar situations.

Finally, Washington was commander-in-chief; it was for him to give orders; he had more than once examined the ground; and Long Island was one of the points from which he had been expecting an attack for four months. His letter of August $25^{\mathbf{1}}$ to Putnam is quite long, but it does not give specific instructions in regard to the disposition of the troops. It does, however, instruct Putnam "at all hazards" to prevent the enemy's approaching his works. Was Washington wise in allowing the troops to remain outside of their works, in the passes two or three miles distant where he had seen them on his visit of the 24th? Considering the quality of his untrained troops, who had never been in a battle in the open, but who had shown wonderful resistance behind trenches, it seems that he made a grave error in not keeping his men in their redoubts, and repeating the performance of Bunker Hill, as they probably would have done.

Howe's report ${ }^{2}$ gives an itemized list of his losses-63 killed, 283 wounded and 31 missing - and of the prisoners taken, 1,097 in all, including 91 officers; and there is no sufficient ground to doubt the accuracy of his figures. The dead and wounded Americans were practically all

${ }^{2}$ Dawson, I, 148, 156; Johnston, 1776, pp. 202-206. 
1776 left within the British lines; their exact number is not known. Washington reported them at "about 1,000." ${ }^{1}$

Precarious Situation on Long Island

Aug. 28

Aug. 28

Preparations for Withdrawal

Washington may have made a mistake in accepting battle in the open, but his next movement was an operation unsurpassed in military skill. It was no longer a question of defending his forts on Long Island. With their garrison demoralized by defeat there might be doubt as to the outcome of an assault; but there was no need for Howe to make an assault. On the afternoon following the battle he began a siege, breaking ground for his first parallel about 600 yards in front of Fort Putnam (Washington Park). With complete command of the sea and an overwhelming superiority in artillery, he could land troops to take the works in reverse, cut off all communication between New York and Long Island and compel a surrender. Washington saw that his troops must be withdrawn from Long Island without a moment's delay and joined to those on Manhattan; and he acted with that extraordinary rapidity which was characteristic of him in such an emergency.

The morning after the battle he brought over from New York three regiments, one of them the "Fourteenth Regiment of Foot" in the Continental Line, commanded by Colonel John Glover, and made up almost entirely of Marblehead fishermen. There were no handier men in a boat than these in all the world; and they rendered great service here in the next two days, as well as later on at Trenton. Washington then sent orders to collect all the small boats in the Harlem River and the East River as far as Flushing. In order not to discourage his men with notice of a retreat, he issued a general order

$$
{ }^{1} \text { Sparks, IV, } 71 .
$$


saying that General Mercer had arrived and that he had 1776 fresh troops from New Jersey which were expected that afternoon; that the sick were an encumbrance to the army and were to be removed to New York; that these troops of Mercer's were to take the place of some of those on Long Island; and therefore all regiments were ordered to parade "with their arms, accoutrements and knapsacks at 7 o'clock at the head of their encampments and there wait for orders." Having made all his preparations, late in the afternoon Washington called a council of war of the eight general officers present and laid the facts before them. ${ }^{1}$ They unanimously advised a retreat; and at dark it began. First the sick were carried down to the ferry; then followed the militia; and after them the Continental regiments. Six of the latter, specially selected under command of Mifflin, were left to man the works until dawn. As the others reached the ferry they found a great number of boats, of all sizes and shapes and deThe Troops scriptions, manned by the men of Glover's regiment, and some from Colonel Hutchinson's Twenty-seventh Foot, which came from Gloucester. General McDougall, who had raised the first New York regiment and had lately been made a brigadier, had charge of the embarkation; and Washington spent the night riding along the mile or more of road which is now Fulton Street, from the ferry to the fortified lines, everywhere encouraging the men and directing their movements.

It was a very dark night, with torrents of rain and a Aug. 29 north-east gale, which at first made it almost impossible even for the Marblehead sailors to handle their boats. Toward midnight the rain ceased and the wind subsided; the crossing then went on rapidly. About 2

${ }^{1}$ Amer. Archives, 5, I, 1246. 
1776 o'clock in the morning a blunder was made which might possibly have wrecked the whole movement. An aidede-camp, mistaking his orders, started Mifflin's entire command for the ferry. Fortunately Washington met them on the road, and led them back to the works.

Just before dawn, by good fortune, a dense fog settled down over the river and the works. Under cover of this, Mifflin's regiments were withdrawn without being noticed by the British in their trenches close by. They reached the ferry and were all carried over, Washington himself accompanying the last of them, in the early morning.

Aug. 30

Washington's Disposition of His Troops

A more skilful operation of this kind was never conducted.

The troops landed near what is now Fulton Street in New York, and joined their comrades in the city and its suburbs. In a few days the army was reorganized into three divisions under Putnam, Spencer and Heath, and posted at various points along the East and Harlem Rivers, from the Battery to Kingsbridge, watching keenly to see where Howe would cross. The troops were greatly discouraged, and the militia, as Washington said sept. 2 in his letter to the President of Congress, were going off "in some instances, almost by whole regiments, by half ones and by companies at a time." " This spread disaffection among the Continentals, and Washington did not hesitate to say that his condition was "still more alarming." In the midst of his cares he found time to write to Congress those excellent recommendations, which will hereafter be quoted, about the formation of a permanent, regular army. ${ }^{2}$ He was not dismayed, nor did he neglect any precautions. He anticipated that Howe would move to Westchester and attack across the

${ }^{1}$ Sparks, IV, 72. ${ }^{2}$ Ibid., IV, 72, 80, 89 . 
Harlem River, and he therefore posted nearly half of his 1776 force in the vicinity of Kingsbridge; he ordered the fortifications at Fort Washington to be completed, and others to be built at Fort Lee on the opposite Jersey shore; and he called a council of war and asked the advice of his generals as to whether New York should be Shall New York be Held evacuated. Greene, then convalescent from his fever, sept. 7 in a strong and ably written opinion advised that the city be immediately evacuated and burned, ${ }^{1}$ so that it should not become a head-quarters and depot of supplies for the British. Washington had asked the instructions of Congress on this point, and they had instructed him to "have especial care taken, in case he should find it necessary sept. 3. to quit New York, that no damage be done to the said city by his troops on their leaving it; the Congress having no doubt of being able to recover the same, though the enemy should, for a time, obtain possession of it." ${ }^{2}$ The other generals were divided in opinion, some being in favor of evacuating; some of defending the city; and some of the middle course, which was adopted, of leaving part of the army in the city, part near Kingsbridge and part at intermediate points. ${ }^{3}$ Within a week Greene sept. 12 headed a petition asking for a reconsideration of the question, and at a new council it was decided by ten to three to evacuate immediately. ${ }^{4}$ A considerable part of

${ }^{1}$ Sparks, IV, 86.

2 Jour. Cont. Cong., V, 733. The expectations of Congress were not realized. New York was the base of operations for the British throughout the war, and they held it until November 25, 1783. If it had been destroyed in 1776, the course of the war might have been quite different. On the other hand, the propriety of destroying a city, even to gain so great a military advantage, might well have been questioned, but apparently it was not. Such an act is now forbidden by the Hague Conventions of 1899 and 1907.

${ }^{3}$ Sparks, IV, 91.

- Amer. Archives, 5, II, 326, 329. 
1776 the stores had already been moved to Fort Washington and the removal of the rest was hastened.

Sept. 6

British Ships in the East

River

Sept. 15

British Land at Kip's Bay

Meanwhile the British ships had assembled near Governor's Island (which had been abandoned), and one of the ships had passed up the East River without being seriously injured, and this was soon followed by others. Howe had spread his men along the shore of the East River as far as Hell Gate, leisurely making his preparations to cross. The crossing was finally made on a Sunday morning from Newtown Creek to Kip's Bay (34th Street), the navy covering the landing with a heavy cannonade. The Americans posted on the shore could not stand the grape-shot. They retired, and 84 boatloads of Guardsmen and Hessians, with Clinton and Cornwallis and Donop in the lead, landed without diffculty. Two brigades which were posted as a support on Murray Hill joined in the retreat toward the Bloomingdale road. Washington heard the cannonade and galloped from his head-quarters, nearly four miles away, at the Morris House. ' He rushed in among the fugitives, used strong language, drew his sword and fired his pistols -all to no purpose. He could not rally them. In the mêlée he narrowly escaped capture, and some thought that he courted death, ${ }^{2}$ as it was with difficulty that his staff dragged him away.

The retreat was general-and speedy; it soon degenerated into a panic and rout, affecting even regiments that had most distinguished themselves at Bunker Hill, and were hereafter to show intrepid courage at Trenton and the Brandywine. Putnam's division came up by the road nearest the North River, and but for the patriotic hospitality of Mrs. Murray, who detained Howe and ${ }^{1}$ Sparks, IV, 93.

${ }^{2}$ Ibid., IV, 95. 
his principal generals at lunch, ${ }^{2}$ a large part of it would 1776 have been captured. By nightfall the remnants of the flying army were gathered on the heights north and west of Harlem, near what is now 130th Street and Manhattan Americans Retreat to Avenue. The losses of the day were 17 officers and 350 men. At dark, Howe's troops were posted across the island from Bloomingdale (97th Street and Broadway) Howe Pursues as far as through McGowan's Pass (Central Park), to Horn's Hook sept. 15 (86th Street and East River).

Naturally Howe was elated and Washington depressed by the events of the day; and the spirits of the American troops were not improved by the heavy rain as they arrived after sunset on the heights north of the "Hollow Way," and there bivouacked on the wet ground without tents. But Washington arranged them in some order, Putnam's and Spencer's division in the rear (147th Street) and Greene's division (which had been commanded by Heath during Greene's illness) in front (127th to 135th Streets west of Manhattan Avenue). Before he went to bed Washington had given orders for Colonel Knowlton and his "Rangers" to reconnoitre in the morning, and sept. 16 find out the dispositions of the enemy. These "Rangers" Knowlton's were a special corps, recently organized, of five picked Rance companies from New England regiments, all good shots; and they were to do constant scouting, in the absence of cavalry. Their officers were splendid young fellows, among them Nathan Hale, who at this moment was absent at his own request, working his way through Connecticut across to Long Island and thence to Manhattan, seeking to gain information for Washington as to the position and movements of Howe's troops. He was destined to be hanged as a spy about a week later, and to be

1 Thacher, 60. 
1776 immortalized by the beautiful statue which now stands in City Hall Park.

Knowlton started on his reconnoissance before dawn, crossed the "Hollow Way," climbed the Claremont Hill (where Grant's monument stands) and moved along the edge of the bluff for more than a mile before he met anything. He then ran into the British pickets and the advance of Leslie's brigade near the Jones house (105th Street near Riverside Drive). There was a sharp skirmish lasting half an hour, and then Knowlton, having accomplished his object and developed a force greater than his own, retreated to the "Hollow Way" (130th Street under Riverside Drive).

Washington was up at daylight, writing to Congress ${ }^{1}$ an account of the "disgraceful and dastardly" retreat of the previous day, and had just finished his report when he heard the firing. He promptly rode to the front and there met Putnam, Greene and Reed (who had succeeded Gates as adjutant-general a few months before). Reed had been with Knowlton. They made their report to Washington to the effect that the party which had followed Knowlton as he retired did not exceed 300 men. Washington seized the opportunity, in the hope of redeeming the disgrace of the previous day, and reinspiring his discouraged men. He planned to capture this detachment which was in plain view across the little valley, sounding their bugles with the fox-hunting calls, as at the end of a hard run. He reinforced the Rangers with the Third Virginia regiment, just arrived from the vicinity of Mt. Vernon, and ordered Knowlton to try to get in rear of the British party, while a feint was made nearer the river by part of one of Greene's Rhode Island ${ }^{1}$ Sparks, IV, 95. 


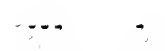
: 


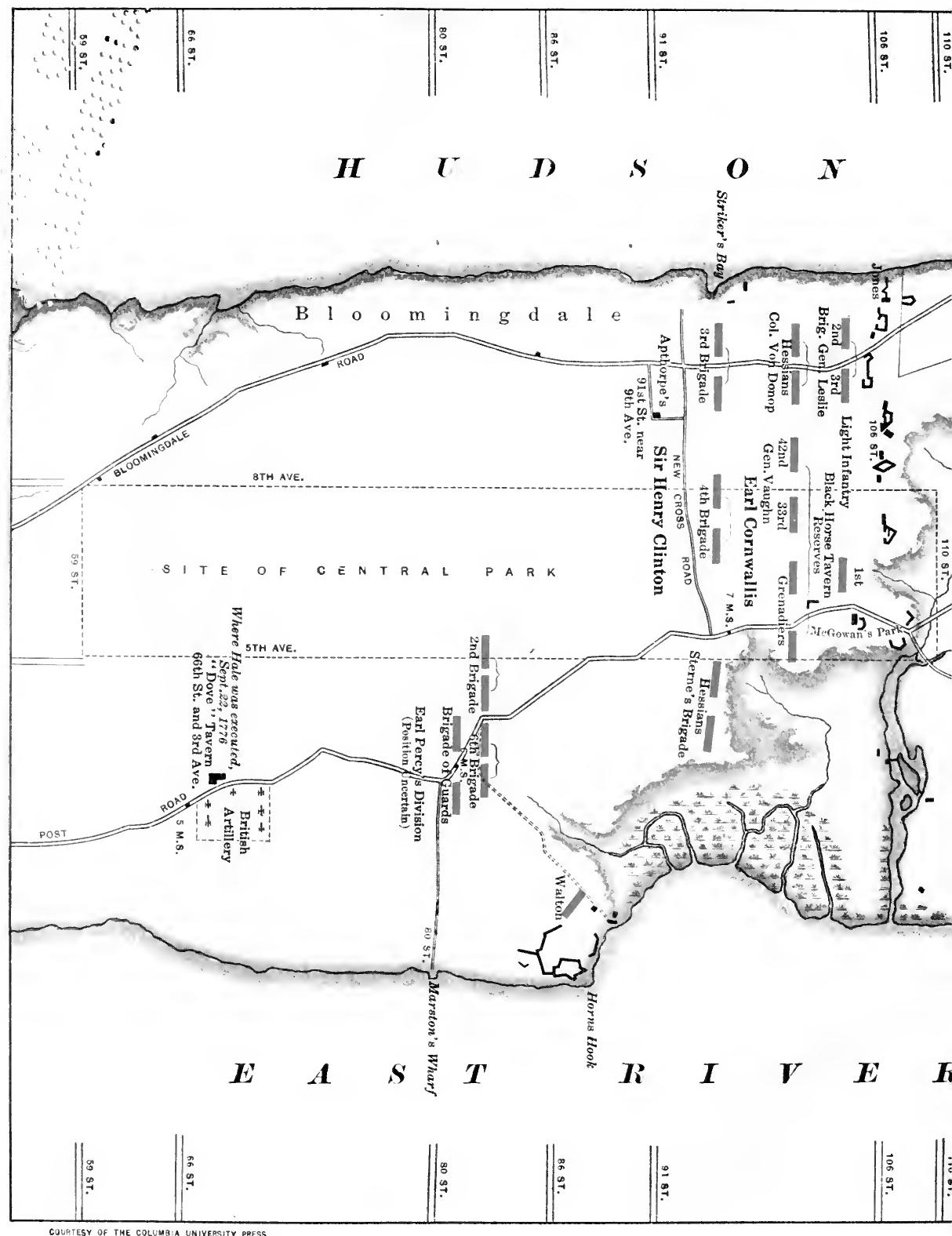

COUATESY OF TME COLUMBIA UNIVEPSTTY PPESS 


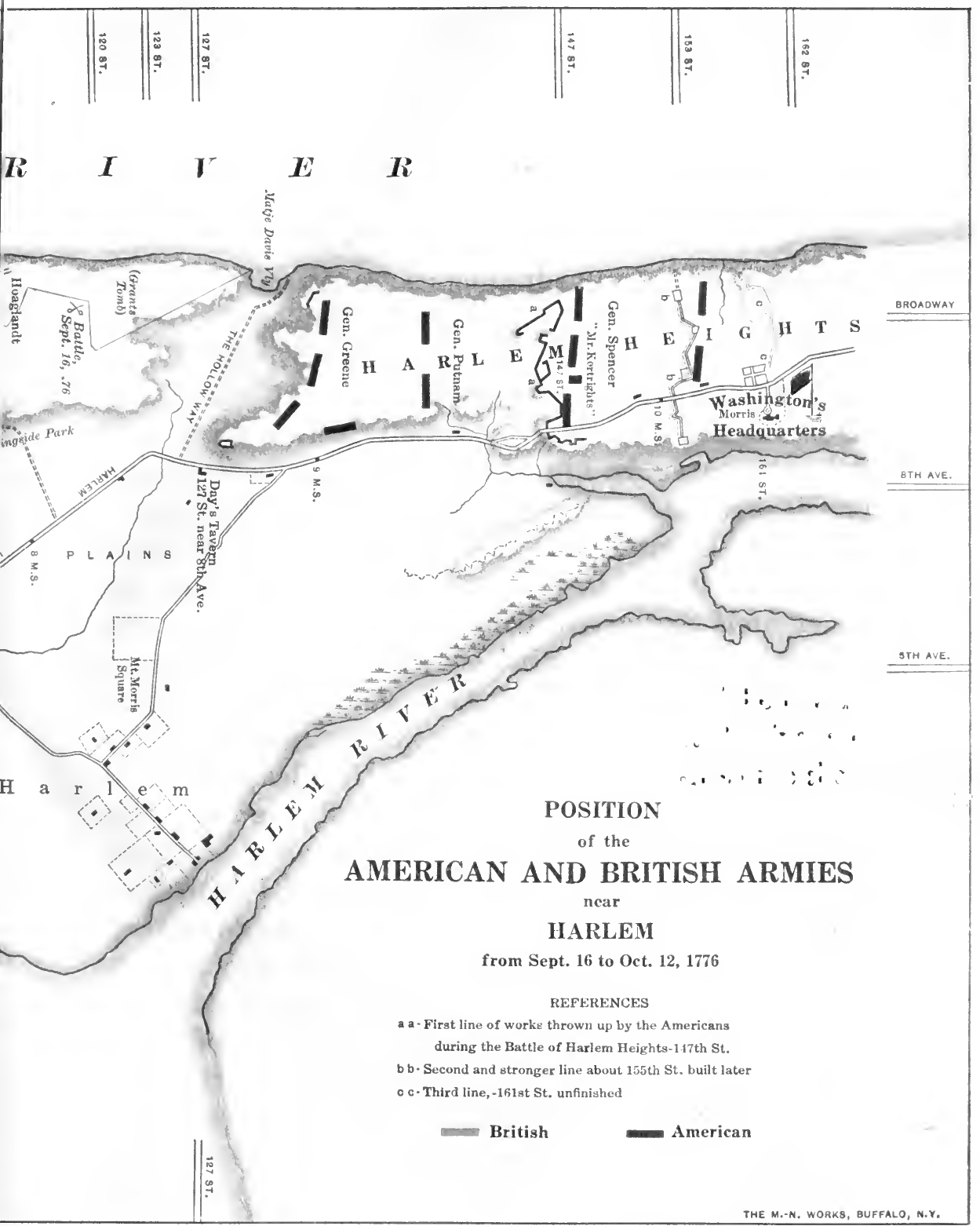

FAJM TME BATTLE OF HARLEM HEIGHTS, BY HENPY P. JOHNSTON 

regiments ${ }^{1}$ under Lieutenant-Colonel Clary. This feint 1776 had the desired effect. The British detachment came down the Claremont Hill to meet them. Before the Rangers could get in their rear the British began to retreat, followed by Clary on their front and Knowlton firing on their flank. In climbing the rocks (about 123d Street and Morningside Park) Knowlton was instantly killed, and Leitch, the major of the Virginia regiment, received a wound from which he died within two weeks. The British continued to retreat until they reached a buckwheat field (120th Street, between Broadway and RiverBattle of Har. lem Heights side Drive), where they were reinforced and made a stand. Washington had also sent in reinforcements, the greater part of Greene's division, so that there were about 1,800 Americans engaged. Putnam, Greene; George Clinton and Reed, were all in the action and all displayed great courage, which animated the men. More reinforcements came up to the British, including the $42 \mathrm{~d}$ Highlanders and some of Donop's Hessians. There was a sharp engagement in the buckwheat field lasting an hour and a half. There were no intrenchments on either side. It was a fight in an open, almost level, field, the two lines being not more than a hundred yards apart. Again the British and Hessians retreated, through an orchard about a third of a mile in the rear, where they made a short stand; and then finally to the vicinity of the Jones house (105th Street), more than a mile from the "Hollow Way," where the action had begun at 11 A. M. It was now about 3 P. M., and Howe had brought up nearly the whole of Cornwallis's division and the Hessians, probably 5,000 men. Washington had no intention of bringing on a general engagement and sent 
1776 an aide to order a retreat. The troops marched back to Harlem Heights in good order and without being molested. Washington's loss was about 30 killed and 100 wounded, and Howe's 14 killed and 157 wounded.

Results of the Action

It was not a great battle; yet the numbers engaged were about equal to, and the losses incurred were greater than, those at Bennington, Stony Point, King's Mountain or Cowpens. Its importance is due to the fact that the same troops which had fled in a disgraceful panic on the previous day at Kip's Bay recovered their courage; drove the British and Hessian regulars before them for more than a mile; fought them in the open at 40 yards' range; and finally, when the object of the movement was accomplished, retreated in good order and without molestation to their own lines. All this had a wonderful effect in restoring the morale of the Continental army. It completely checked Howe's advance. He made no offensive movement for nearly four weeks, contenting himself with fortifying the hills from Bloomingdale through McGowan's Pass to Hell Gate, while Washington was fortifying the opposing heights north and west of Harlem. There were three distinct lines of trenches and redoubts, extending from the Hudson River to the Harlem Plain, one on the present site of 147th Street, the next at 153d Street and the third at 162d Street. On the hill at 182d Street a large pentagonal bastioned redoubt (Fort Washington) was constructed, the remains of which are still visible. It was capable of holding 2,000 men; it was 200 feet above the water; it commanded a fine stretch down the river as well as across it; and in connection with Fort Lee on the opposite Jersey shore and a line of sunken vessels, booms and chains in the river, it was intended to prevent the British 
men-of-war and transports from passing up the Hudson.

Great was Washington's disappointment when it was shown that these works could not effect that purpose. Two frigates sailed up the river with a favorable breeze; and although bombarded by the guns of the forts on both oct. 9 sides, they passed the obstructions without serious injury.

Howe's next plan was to move past Washington's flank-a movement quite similar to that which Grant made on a much larger scale in 1864. The lines which Washington had built on Harlem Heights were very strong, and they were defended by $14,750^{1}$ men, who had shown in the engagement of September 16 that they were still full of fight. Howe wisely decided not to assault these works. His own lines were now strong enough to be held by a small force, which would make New York safe from recapture. Leaving Lord Percy's division in these works he embarked the rest of his army in small boats at 86th Street and moved them through the Sound to Throg's Neck. This movement threatened oct. 12 Washington's communications, but it was not effectual. Throg's Neck is connected with the main-land by a causeway and bridge crossing Westchester Creek. Washington sent a few regiments to destroy this bridge and take position on the west side of the creek. Howe could not have forced the crossing without great loss; he therefore put his men in boats again and moved them across the water to Pell's Point, ${ }^{2}$ south of New Rochelle. Washington met this movement by extending Spencer's division oct. 18 along the hills behind the Bronx, with their outposts out on the shore of the Sound in touch with Howe's landing parties. Three days later Washington arrived at White

${ }^{1}$ Sparks, III, 493; Amer. Archives, 5, II, 910.

2 Howe's Report, Dawson, 185. 
1776 Plains, ${ }^{1}$ about eight miles north of New Rochelle, with oct. 21 Heath's division; and a few days afterward he was joined by Sullivan's, Stirling's and Lee's divisions. He then had at White Plains about 13,000 men-his entire army except about 2,000 men left at Fort Washington, and 4,500 at and near Fort Lee, which were under the command of Greene. ${ }^{2}$ Howe had a slightly larger number.

Battle of White Plains

Washington selected a position near White Plains, fortified it by two lines of intrenchments and there awaited Howe's attack. The trenches were on slightly rising ground, the left protected by swampy ground and the right resting on the Bronx River. Beyond the right was a piece of high ground, called Chatterton's Hill, which commanded the plain over which Howe would have to advance. It was occupied by Haslet's Delaware regiment, with two guns of Captain Alexander Hamilton's battery, and supported by McDougall's Brigade; in all about 1,600 men. $^{3}$

Although Howe outnumbered Washington he deemed it unwise to attack the main position until he had gained possession of this Chatterton's Hill. He therefore sent oct. 28 Leslie with his own brigade and three regiments of Hessians, about 4,000 men in all, to dislodge Haslet. They forded the Bronx and advanced up the hill, their attack preceded by a sharp artillery fire from thirteen guns posted on the east side of the Bronx. Such effective resistance was made by two excellent regiments in McDougall's 10 s.s. brigade and by Hamilton's two guns that the first attack failed. Later it was renewed in front, while Rall, with one of the Hessian regiments, made his way around

${ }^{1}$ Sparks, IV, 524.

${ }^{2}$ Ibid.; Amer. Archives, 5, III, 663.

${ }^{3}$ Dawson, 179, 184. 

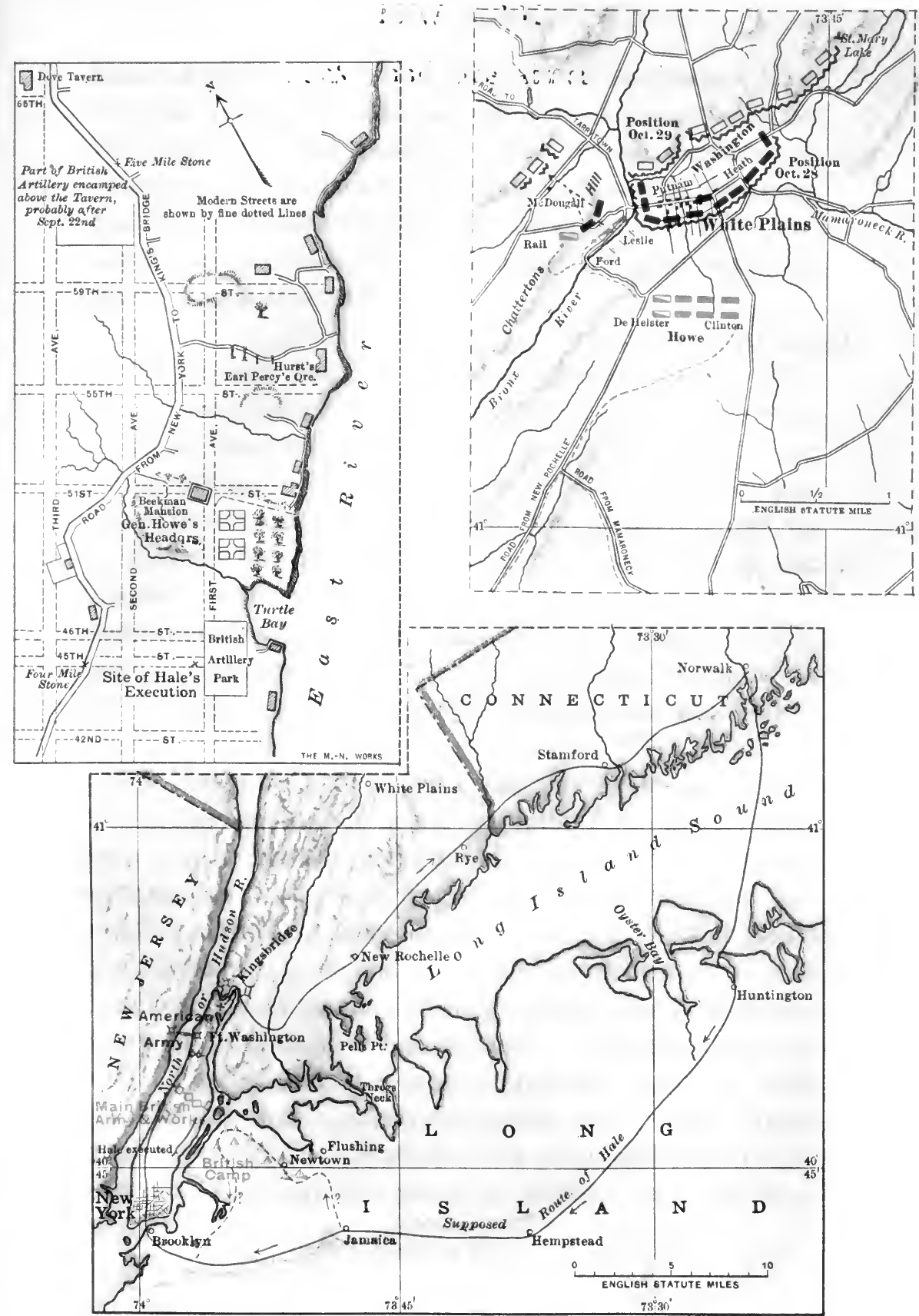

Courtesy of The Burrows Brothers Company Publishers, Cleveland, Ohio

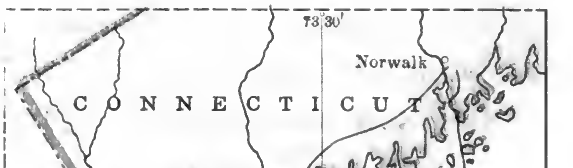

White Plains, Oct. 28, 1776

Movements of Nathan Hale, Sept. 10-22, 1776 


$$
\begin{aligned}
& \because \because \vdots \quad \because: \because, \\
& \therefore \therefore \therefore \therefore \therefore, \therefore, i, \cdot \leq
\end{aligned}
$$


Haslet's right flank; and this attack succeeded. Mc1776

Dougall retreated, bringing off the guns and joined Washington's main position. The British loss was 28 killed, and 126 wounded; 5 officers being among the killed, and 5 among the wounded; the Hessians lost 77. ${ }^{1}$ The American loss was not reported in detail but was estimated at less than 200 .

Howe thus gained Chatterton's Hill, but he did not oct. 30 attack the main lines that day nor the next. On the third day he was reinforced by two brigades of Percy's division, which he had ordered up from New York; and by the second division of Hessians under Knyphausen which had just arrived from Europe. This brought his strength up to about 20,000 men, and he determined to attack on the oct. 31 following day. A storm delayed the movement and, Nov. 1 under cover of the storm during the next night, Washington withdrew five miles to a strong position on the heights of North Castle. Howe did not follow him. ${ }^{2}$

The chief object of Howe's manœuvre-to get in rear of Washington, and by occupying a line from Long Island Sound to the Hudson to surround him and cut off his communications with New England-had thus failed. He had, nevertheless, succeeded in dividing Washington's small force into three bodies, one in New Jersey, at or near Fort Lee, one on Manhattan Island, at or near Fort Washington and the third at North Castle. The main body, at North Castle, and the most important post, at Fort Washington, were twenty-five miles apart; and Howe was between them. Moreover, his ships had shown that they could ascend the river; he could obtain his sup-

${ }^{1}$ Howe's Report, Dawson, 184-185; Lowell, 301.

Dawson, 186. 
plies by water and could concentrate his troops at any point along the river.

This faulty disposition of Washington's troops invited disaster, which was not long in arriving. It was due to the unanimous desire of Congress that the last remaining point on Manhattan Island-Fort Washington-should not be abandoned. Congress sent Washington resolutions ${ }^{1}$ to this effect, and these unfortunately influenced the better judgment of Washington, and also of his generals.

Early in November there were in service 106 regiments, of which about one-third were Continentals and two-thirds militia. They numbered on paper about 2,400 officers and 40,000 men;" but the "rank and file, present, fit for duty," were only about 19,000. Gates at Ticonderoga had about 6,000; Heath, in the Highlands, with headquarters at Peekskill, had about 3,000 ; Lee, at Nor'h Castle, on the Croton River, had 5,000; and there were 2,700 at Fort Washington, and an equal number at Fort Lee, both under command of Greene. Howe, with nearly 20,000 men, was at Dobb's Ferry on the Hudson, about midway between Lee and Greene; he had fully 10,000 more at New York and Staten Island. ${ }^{3}$ Carleton, with nearly 10,000 men, was at Crown Point, and had just defeated Arnold in a spirited naval engagement on

oct. 11 Lake Champlain." After that he retired to Canada and

Nov. 2 went into winter quarters.

As previously stated, when Washington withdrew from

Nov. 1 White Plains to North Castle, Howe did not follow him.

${ }^{1}$ Jour. Cont. Cong., VI, 866.

${ }^{2}$ Returns of November 3, November 9, November 13. Amer. Archives, 5, III, 499, 663, 702.

${ }^{3}$ Sparks, V, 542.

${ }^{4}$ Sparks, IV, 155; Dawson, 167-174. 
On the same day he sent a detachment from his troops 1776 at New Rochelle to occupy the heights north of Spuyten Duyvil; and a few days later he moved his main body Nov. 5 from White Plains to Dobb's Ferry. Washington immediately saw what Howe's plan was. "That they will invest Fort Washington is a matter of which there can be no doubt. ${ }^{1}$... I think it highly probable, and almost certain, that he will make a descent with a part of his troops into Jersey." 2 He prepared to meet this situation as fully as the force at his disposal would permit. Greene had written asking for instructions in regard to oct. 31 Fort Washington, and Washington had replied leaving the matter to Greene's discretion, only reminding him of the previous intention to hold the fort to the last. While Howe was transferring his base from the Sound to the Hudson River he ordered vessels to come up to meet him at Dobb's Ferry. A frigate and two transports broke Nov. 5 through the obstructions and passed up the river. Greene reported this to Washington, ${ }^{3}$ and on the same day nov. 7 Washington advised Greene of Howe's movements, and his interpretation of them, and said that he should probably come in person with "the troops designed for the Jerseys." " When Washington, on the following day, received Greene's report of the passage of the British ships up the river, he began to doubt the advisability of attempting to hold Fort Washington any longer. $\mathrm{He}$ immediately wrote to Greene, ${ }^{5}$ expressing such doubts, Nov. 8 and saying: "I am therefore inclined to think that it will not be prudent to hazard the men and stores at Mount Washington; but as you are on the spot, leave it to you

${ }^{1}$ Sparks, IV, 163.

Amer. Archives, 5, III, 556.

Amer, Archives, 5, III, 602; Sparks, IV, 164
Ibid., IV, 159.

Ibid., 5, III, 557. 
to give such orders as to evacuating Mount Washington as you judge best, and so far revoking the order given to Colonel Magaw to defend it to the last."

Washington had by this time come to have great confidence in Greene's judgment. Greene was himself the soul of loyalty. Had Washington given him an order it would have been promptly obeyed, whatever his own opinion might have been. Washington not only did not give an order, but he did not intend to give one. He intended to-and did-advise Greene that the views he had previously entertained and had expressed the last time he saw Greene had been modified by subsequent events, and without giving any positive orders he left it to Greene's discretion to act as he thought best. Judged by the result, Greene decided wrongly.

Congress had passed urgent resolutions that the fort should be held.' At a council of war, where sixteen general officers were present-including every prominent officer in the army except Greene himself, who was absent in New Jersey-it was unanimously "agreed, that Fort Washington be retained as long as possible." ${ }^{2}$ Colonel Robert Magaw, of Pennsylvania, who commanded in Fort Washington, and was considered one of the best regimental commanders in the Continental service, advised Greene that he could hold the fort until the end of the year. ${ }^{3}$ Greene concurred in this view, believing that the garrison would make as vigorous a defence as at Bunker Hill. He therefore exercised, unwisely, the discretion vested in him by deciding not to withdraw the garrison. When Washington arrived the responsibility of de-

1 Jour. Cont. Cong., VI, 866.

${ }^{2}$ Amer. Archives, 5, II, 1117; Sparks, IV, 155.

Amer. Archives, 5, III, 619. 


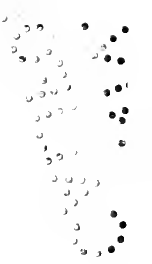




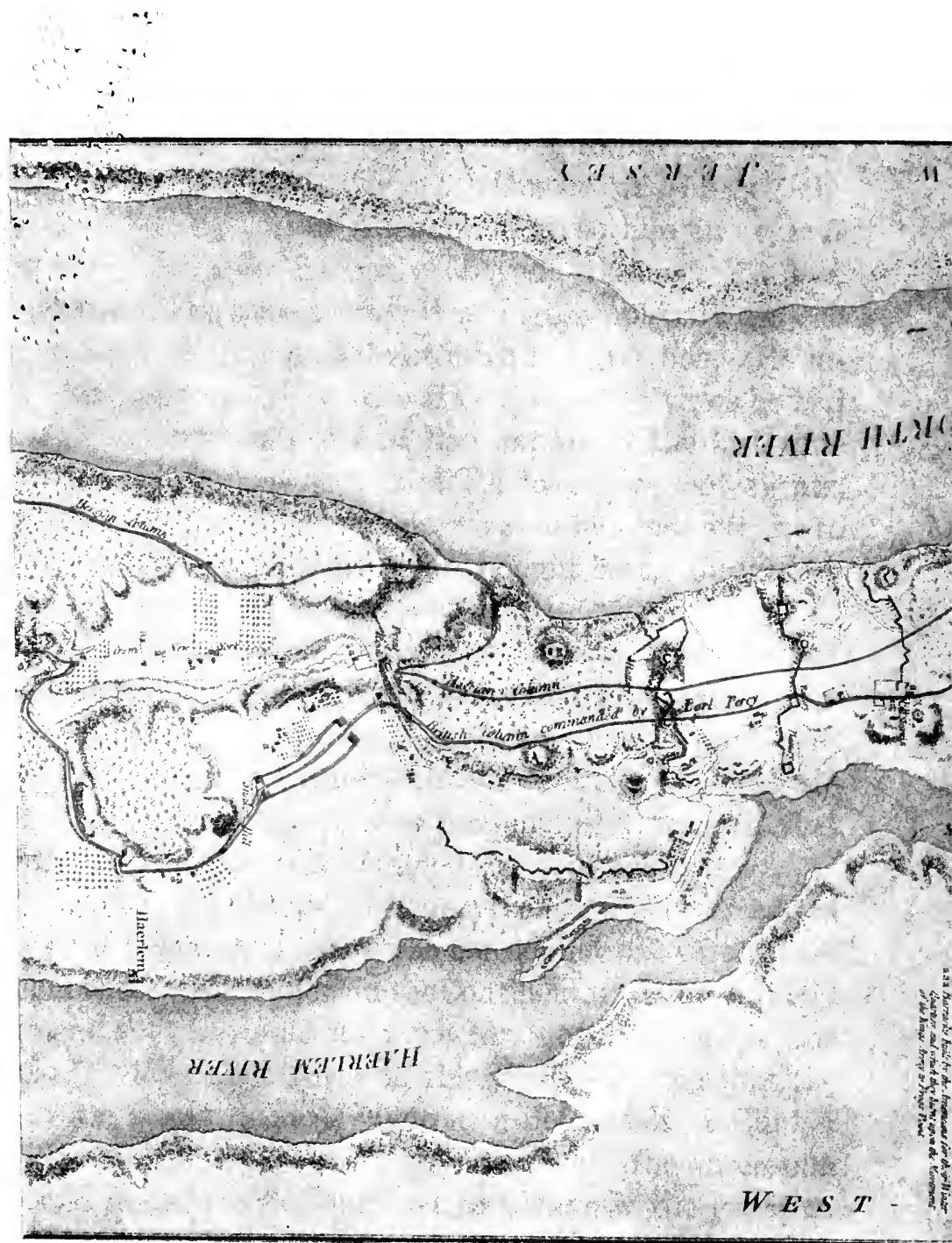

Courtesy of The Burrows Brothers Comprany, Pullishers, Cleveland, Uhio 


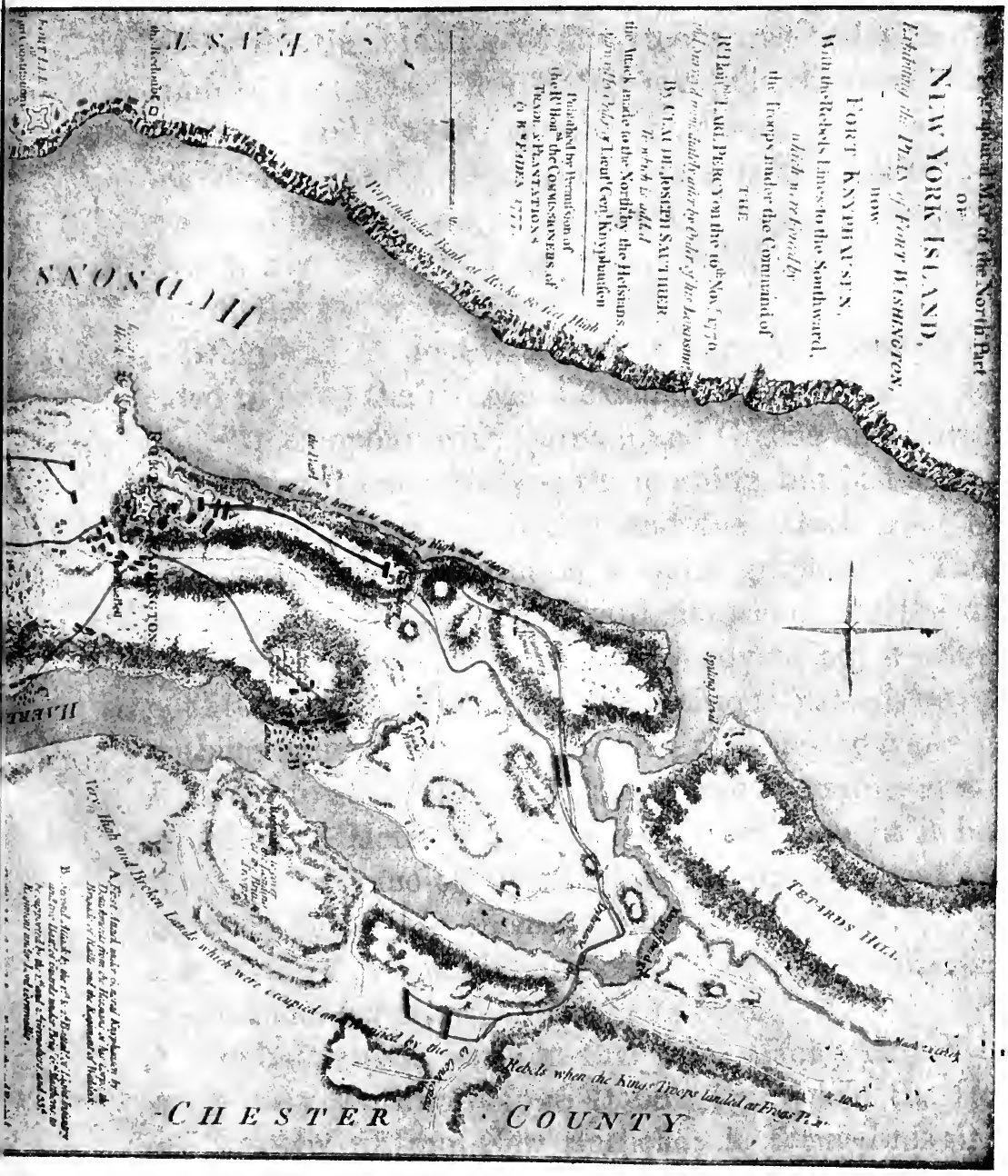

From Avery's History of the United States and Its P'eople 

ciding the question rested on him. He had left White 1776 Plains, taking Putnam and Mercer and a small body of troops with him, had crossed the Hudson at King's Ferry Nov. 12 (Stony Point-Verplanck's Point), and riding down on the Jersey side in advance of his troops, reached Greene's Nov. 13 camp at Fort Lee. The matter was fully discussed, but, as Greene said, "finally nothing concluded on" $;{ }^{1}$ and as Washington said," when three years later Charles Lee criticised his leadership, the discussion "caused that warfare in my mind, and hesitation, which ended in the loss of the garrison."

Being still in doubt, two days later Washington decided to cross the river and examine the position in person. In company with Putnam and Greene and Mercer, Nov. 16 he was rowed across early in the morning, but just as they landed the cannonade began, and the attack soon followed. Greene's description is quite graphic." "There we all stood in a very awkward situation. As the disposition was made and the enemy advancing, we durst not attempt to make any new disposition; indeed, we saw nothing amiss. We all urged his excellency to come off. I offered to stay. General Putnam did the same, and so did General Mercer; but his excellency thought it best for us all to come off together, which we did, about half an hour before the enemy surrounded the fort." This was certainly a humiliating position for the commanderin-chief and his principal officers to be in.

The battle took place in this wise. Howe moved his main body southward from Dobb's Ferry, and the HesLoss of Fort Washington sians westward from New Rochelle; he formed his principal line on the heights, north and east of Harlem River,

${ }^{1}$ Greene to Knox, Knox, 33.

2 Sparks, VI, 329.

Ibid., 34. 
1776 between the Hudson and the Bronx. In advance of them, the Hessians occupied a position south of Harlem River at Kingsbridge, and Cornwallis another position (University Heights) east of the river, both of which they fortified; while Percy brought part of his division from McGowan's Pass up to the "Hollow Way" (125th Street and Manhattan Avenue). The Americans were thus surrounded by something more than 13,000 men $^{1}-12$ British and 15 Hessian regiments. Thirty flatboats were brought up the Hudson from New York, and during the night succeeded in passing Fort Washington and through Spuyten Duyvil into the Harlem River south of Kingsbridge. Howe was fully posted as to the American position by the adjutant of Magaw's regiment, ${ }^{2}$ who had deserted two weeks before and given Howe plans of all the works and the strength of the garrison.

Magaw, on the American side, commanded three regiments: his own and Shee's (now under Cadwalader) from Pennsylvania, and Rawlings' of Maryland; and detachments from the so-called "Pennsylvania Flying Camp," under Colonel Baxter, equal to about three more regiments. Cadwalader was in the lines from 165th Street south to the "Hollow Way"; Rawlings was in those on the heights near the Hudson, south of Inwood, Baxter at Laurel Hill (Fort George) on the Harlem, and Magaw in Fort Washington. ${ }^{3}$

Nov. 16,

The attack began almost simultaneously on three sides, Knyphausen and Rall leading the Hessians in two columns against Rawlings, Cornwallis landing from the thirty boats and scaling the heights of Fort George against Baxter, and Percy crossing the "Hollow Way"

${ }^{1}$ Amer. Archives, 5, III, 1058.

2 Lossing, II, 619.

3 Dawson, 189. 
and attacking Cadwalader. The attack was preceded and 1776 covered by a heavy artillery fire from the east side of the Harlem River. ${ }^{1}$ Cadwalader made only a feeble resistance and fell back toward Fort Washington; but Rawlings defended his position with great vigor, and it was only after two hours of hard fighting and heavy losses that the Hessians, with their enormous superiority of force, were able to drive him back. ${ }^{2}$ Baxter was mortally wounded, and his men retired before Cornwallis. Learning that Cadwalader was retreating, Howe ordered a fourth attack, which had originally been intended as a feint, to be made vigorously by the $42 \mathrm{~d}$ Highlanders, crossing the Harlem in boats and climbing a steep hill near the Morris House (165th Street), and trying to intercept Cadwalader. Magaw sent a detachment to oppose this, and the Highlanders lost heavily; but they finally carried the hill and captured the detachment. They were, however, so delayed that they were unable to intercept Cadwalader, and he succeeded in reaching Fort Washington. ${ }^{3}$

Early in the afternoon all the Americans, more or less demoralized, had been driven from their outlying works into Fort Washington. After some parleying Magaw surrendered the entire body to Knyphausen. ${ }^{4}$

Howe at first followed up his victory with energetic Nov. 18 pursuit of the troops in New Jersey. Leaving the Hessians with their prisoners, he sent Cornwallis with twelve Nov. 19 regiments across the Hudson at Yonkers, and marching down behind the Palisades he arrived in rear of Fort Lee. Greene had detected the movement; and sending

1 Howe's Report, Dawson, 194.

2 Ibid., 195; Lowell, 80-84; Eelking, 51.

Sparks, IV, 180.

' Dawson, 191, 195. 
1776 report of it to Washington (who was at Hackensac, assembling the men he had brought from North Castle) Greene brought off the garrison of Fort Lee during the Nov. 20 night, and reached the Hackensac bridge only a few hours before Cornwallis. Here he was joined by Washington, and a brief stand was made to cover the retreat of the Nov. 23 troops at Hackensac village, behind the Passaic. Then the retreat was continued to Newark. ${ }^{1}$

Howe's losses at Fort Washington were 78 killed, 374 wounded and 6 missing. About three-fourths of the losses were in the Hessian regiments under Knyphausen, which attacked Rawlings from the north. The American loss was 59 killed and 2,818 prisoners, of whom 96 were wounded. Adding 105 captured at Fort Lee, the total loss of the Americans was approximately 3,000 men. The British chief of artillery made an itemized report of the artillery, ${ }^{2}$ ammunition and stores taken in the two forts; it included 146 pieces of artillery, over 12,000 shot, shell and case, 2,800 small-arms and 400,000 musket cartridges. The Continental treasury and the limited resources of the Colonies in gun factories were in no condition to stand such a loss.

From every point of view it was a terrible disaster.

Results of the Loss of Fort Washington
Had Howe pursued Washington with the same relentless energy and well-directed skill that Grant pursued Lee eighty-eight years later, it is hard to see how the Continental army could have escaped destruction. Howe had nearly 30,000 regular troops, as good as any in the world. He had captured the city of New York and the line of the Hudson for forty miles above it-and that comprised about all there was of the State of New York

${ }^{1}$ Sparks, IV, 187, 189.

2 Amer. Archives, 5, III, 1058, 1059. 


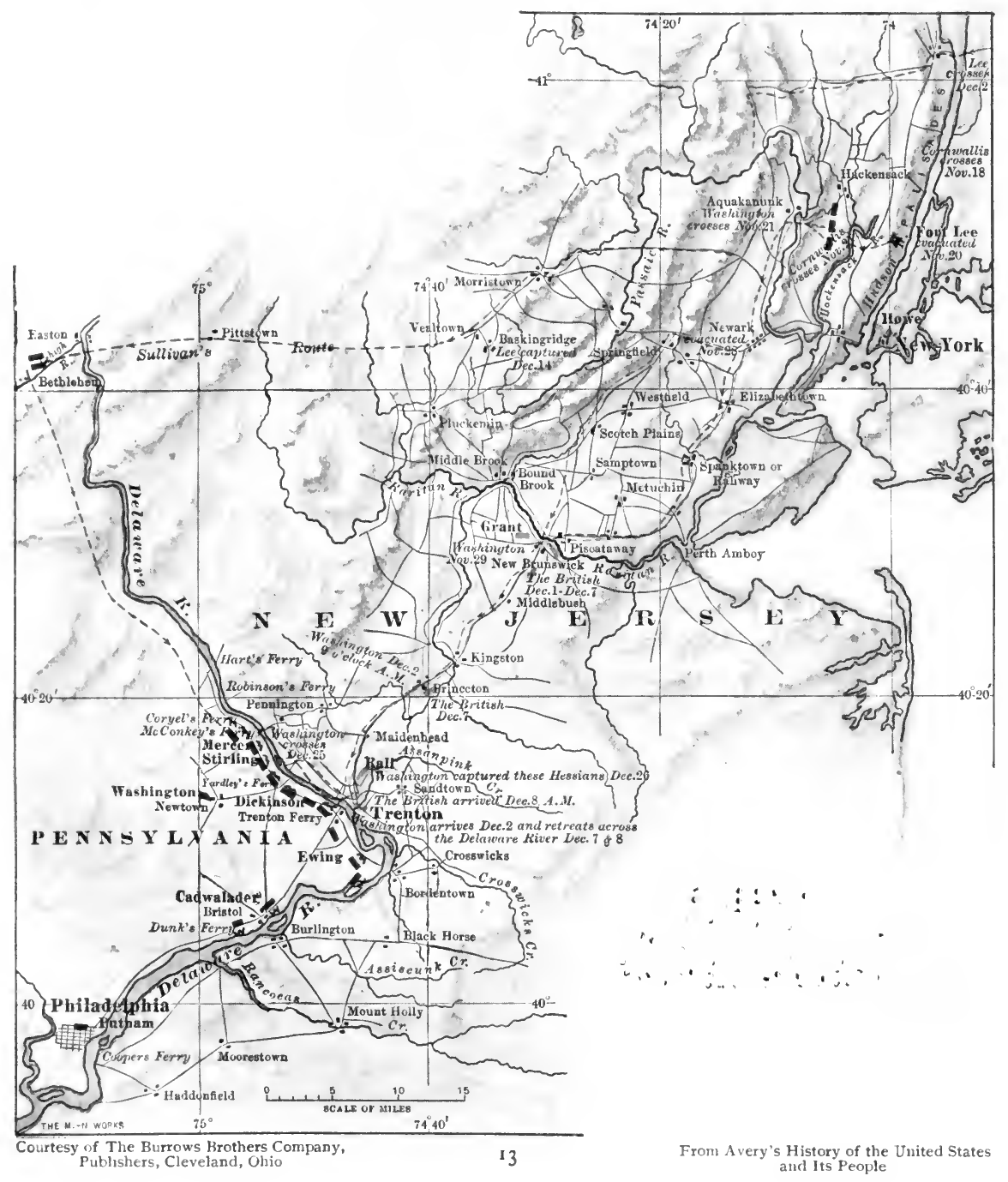

Retreat through New Jersey

Nov,-Dec., 1776 
, 
at that time, the settlements around Albany being little 1776 more than Indian trading-posts. He had complete command of the river, with over 300 transports protected by nearly 80 vessels of war. Properly handled, these could have prevented any of Lee's division from crossing the Hudson to join Washington, and with their aid a comparatively small land force could either have captured Heath at Peekskill and Clinton at Fort Montgomery, or driven them away from their posts, and given Howe the much-desired command of the Hudson to Albany. By controlling the Hudson and remorselessly following Washington's few remaining regiments wherever they went, and keeping the field as long as they kept it, notwithstanding the season, he could have ended the war before spring.

Perhaps he did not know the despondency prevailing on the American side. John Adams, the most important American Despondency man in Congress-President of the Board of War and member of the committee to seek aid from foreign nations-had gone home to spend three months with his family in Massachusetts. ${ }^{1}$ Congress was ready to pass the resolutions, which it did pass a few weeks later, ${ }^{2}$ to Nov. 23 make Washington dictator, and adjourn to Baltimorewhere there would probably have been no quorum, if Washington had failed at Trenton. Washington himself wrote to Congress ${ }^{3}$ from Newark that "the situation of our affairs is truly critical," and to his brother, ${ }^{4}$ a little later: "In a word, if every nerve is not strained to recruit Dec. 18 the new army with all possible expedition, I think the game is pretty nearly up."

${ }^{1}$ Morse, Life of John Adams, 146; Familiar Letters of John Adams, 233.

2 Jour. Cont. Cong., VI, 1027.

${ }^{3}$ Sparks, IV, 190.

I Ibid., IV, 231. 
1776

Howe Goes into Winter Quarters

Dec. 20

Dec. 8

Washington Retreats to the Delaware

Nov. 29

Dec. 3

Howe missed his chance. Instead of driving Washington to Philadelphia and dispersing his army as its enlistments expired, he halted Cornwallis, first at Brunswick, and then at Trenton; and went into winter quarters, saying (to Lord George Germain) ${ }^{1}$ that his intention did not extend beyond getting and keeping possession of East Jersey. Instead of seizing and holding the Highlands of the Hudson he sent Sir Henry Clinton, with 6,000 troops and a large part of the navy, to Newport, intending in the spring to capture Providence and thus penetrate into New England. ${ }^{2}$ There was no enemy at Newport, and the place was captured without resistance; the advance to Providence was never made, and the British troops which spent the next three years at Newport made the inhabitants miserable but accomplished no military purpose.

Howe, having thus completed his plans for a quiet winter, Washington, by a supréme effort of genius and daring at Trenton, changed the whole situation. No second opportunity like that of December, 1776, ever came to Howe or his successor.

Washington had been only a few days at Newark when Cornwallis appeared on the opposite side of the river; simultaneously the Hessians crossed the Passaic above his left flank, and it was rumored that Howe was embarking men for Staten Island, to turn his right by way of Amboy. ${ }^{3}$ Washington therefore retreated to Brunswick and a few days later to Trenton, and took position behind the Delaware, having taken the precaution to secure all the boats on the river for 70 miles above Philadelphia. ${ }^{4}$ His force was reduced to about 3,000 men, ${ }^{5}$

${ }^{1}$ Amer. Archives, 5, III, 1316. $\quad{ }^{2}$ Sparks, IV, $220 . \quad{ }^{3}$ Ibid., IV, 194.

‘ Amer. Archives, 5, III, 1027, 1120, $1152 . \quad$ 'Ibid., 5, III, 1035. 
whose enlistments would expire at the end of the month.

With his soldierly instinct he felt sure that Howe would pursue him with his entire force, attempt to cross the Delaware above or below him, crush him in action and push on to Philadelphia. So convinced was he that Howe would adopt this plan that he wrote to Congress ${ }^{1}$ Dec. 8 . that "the object of the enemy cannot now be doubted in the smallest degree." He therefore suggested that Phila- Dec. 9 delphia should be fortified, and sent Putnam there to take charge of the works, and Mifflin along with him to take charge of the stores and aid in raising the militia, with whom he had great influence. Congress, after conferring with Putnam and Mifflin, passed a resolution, ${ }^{2}$ "That the Continental general commanding at Philadelphia be directed to defend the same to the utmost extremity," and adjourned, to meet later in Baltimore. Dec. 12

There was no stampede on Washington's part. Whatever he might write privately to his brother, he showed no lack of confidence to those around him, in his letters to public officials and in his orders to his subordinates. At no time in his whole career did he act with more intense energy than during these three weeks in December, writing almost daily letters ${ }^{3}$ to the governors of States and to Congress, suggesting measures for raising troops and apologizing for those which he himself had taken if they should seem to exceed his authority. "A character to lose, an estate to forfeit, the inestimable bless- $\begin{gathered}\text { Congress, } \\ \text { Dec. } 20\end{gathered}$ ings of liberty at stake, and a life devoted, must be my excuse." 4

On leaving White Plains he had given Lee formal and explicit orders in writing as to what Lee should

${ }^{1}$ Sparks, IV, 206-208.

'Sparks, IV, 200-264.
2 Jour. Cont. Cong., VI, 1026, 1027.

'Ibid., IV, 235. 
1776 do in certain contingencies, and the most important part Nov. 10 of these orders directed Lee, ${ }^{1}$ in case the enemy should cross the Hudson, to follow "with all possible despatch." Nov. 16 After the loss of Fort Washington he sent orders to Lee to bring his entire force to join him. ${ }^{2}$ While at Newark, Congress authorized him to call upon Schuyler for the Pennsylvania and Jersey troops, and the instant he received the resolution he wrote to Schuyler ${ }^{4}$ to send them.

Lee's Dilatory March

Oct. 14

All of these instructions were promptly carried out except in the case of Lee. That officer had recently returned from the South, much inflated in his own estimation, as well as that of more judicious men like Jay and Duer, ${ }^{5}$ by the victory at Charleston, the credit of which in reality was due to Moultrie and not to himself. The succession of disasters and retreats, from Long Island to White Plains and from Fort Washington to Newark, filled his traitor's mind with the thought ${ }^{\circ}$ that perhaps people could be induced to believe that Congress had made a mistake in the selection of a commander-in-chief sixteen months before, and that a soldier who had seen service under the King of England, the King of Poland, and the Empress of Russia might be selected as his successor. He was therefore in no hurry to join Washington; to the latter's repeated instructions to hasten his march he returned frivolous replies, meanwhile writing to his friends, ${ }^{7}$ Reed and Rush and Gates, wondering if Washington was such a great man as had been thought. Finally, however, Washington's orders became so imperative that he dared not disobey, and he put his command in motion ten days after he had received the first

${ }^{1}$ Sparks, IV, 170.

${ }^{3}$ Jour. Cont. Cong., VI, 977.

${ }^{5}$ Moore, 37.

'Ibid., 38, 42; Reed, I, 255; Sparks, IV, 535.
2 Ibid., IV, 186, 187, 192, 193.

' Sparks, IV, 192.

I Ibid., 49, 50. 
order. He crossed the Hudson at King's Ferry (Stony $177 \hat{0}$ Point-Verlpanck's Point), and had to make a détour by Dec. 2 way of Morristown in order to avoid Cornwallis. He marched as slowly as possible-40 miles in 8 days-and one night, while sleeping at a tavern at Baskinridge, 3 Dec. 12 miles from his command, he was captured by Cornwallis's dragoons and carried a prisoner to Howe. ${ }^{1}$ The latter at first thought of treating him as a deserter from the Capture of Lee British army; and for this or other reasons Lee undertook to advise Howe as to the strength and position of the American army and the best means of compassing its destruction. He even went so far as to hand to Howe, in his own handwriting, a plan for the next campaign, ${ }^{2}$ which Howe put away among his papers, where it was not discovered till nearly eighty years later.

Of all this, of course, Washington knew nothing; he did know, although he could not account for it, that Lee was very slow in joining him. His troops did finally arrive under Sullivan, and Heath and Gates arrived Dec. 20 almost at the same time.

Washington seems to have had a very good service of information $;^{3}$ for his letters show that at this time he had learned, to his surprise, that Howe had gone into winter quarters, instead of intending to attack him and try to capture Philadelphia. As soon as he learned this, Washington determined on his counter-stroke. The reinforcements he had received had been partly counterbalanced by expiration of enlistments and the melting away of the militia, but he had with him now 30 small Continental regiments, containing 4,160 men, present for duty. They were organized into 8 brigades and 2 divi-

${ }^{1}$ Moore, 52-59; Sparks, 530-541.

Moore, 84.

Sparks, VI, 39, 255. 
1776 sions, ${ }^{1}$ under command of Sullivan and Greene. They were posted on the west bank of the Delaware, guarding all the fords for 20 miles above the big bend of the river at Bordentown. Lower down the river, at Bristol, was Colonel John Cadwalader with a regiment of Pennsylvania militia. Washington's head-quarters were in rear of the centre of his line, at a hamlet called Newtown."

Howe's orders ${ }^{3}$ for winter quarters had placed 6 brigades, probably 15 regiments, in Princeton and Brunswick, and 6 regiments of Hessians ${ }^{4}$ under Donop, on the Delaware from Bordentown to Burlington, 3 of them being at Trenton under Colonel Rall. The total force was

Dec. 8

Dec. 20

Dec. 23

Washington Crosse the Delaware about 12,000 men. Cornwallis had attempted, two weeks before, to turn Washington's left flank by crossing the Delaware at Coryell's Ferry, but finding no boats had given up the attempt; and when the troops went into winter quarters had returned to New York, intending to go to England on leave of absence until spring. He had turned over the command to Major-General Grant. ${ }^{5}$

Washington wrote to Cadwalader at Burlington, "Christmas day at night, one hour before day, is the time fixed for our attempt upon Trenton. For Heaven's sake, keep this to yourself. . . . I have ordered our men to be provided with three days' provisions ready cooked, with which, and their blankets, they are to march; for if we are successful . . . we may push on." Washington's plan was to cross the Delaware at McKonkey's Ferry, nine miles above Trenton; then march down the east bank in two columns, Sullivan's division on the river

${ }^{1}$ Amer. Archives, 5, III, 1401; Sparks, IV, 244.

2 Sparks, IV, 232, 243.

3 Howe to Germain, Amer. Archives, 5, III, 1317.

Lowell, 87; Eelking, 59.

${ }^{5}$ Amer. Archives, 5, III, $1318 . \quad{ }^{\circ}$ Sparks, IV, 241. 


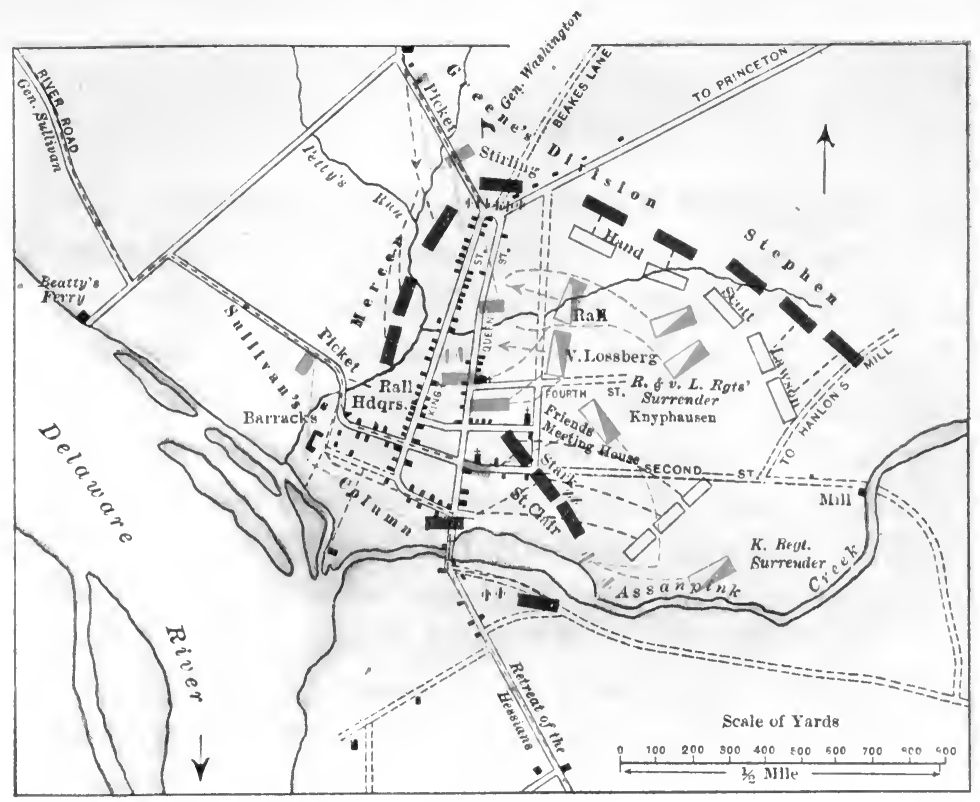

TRENTON

Dec. 25,1776

14

Courtesy of The Burrows Brothers Company, Publishers, Cleveland, Ohio From Avery's History of the United States and Its Pepole

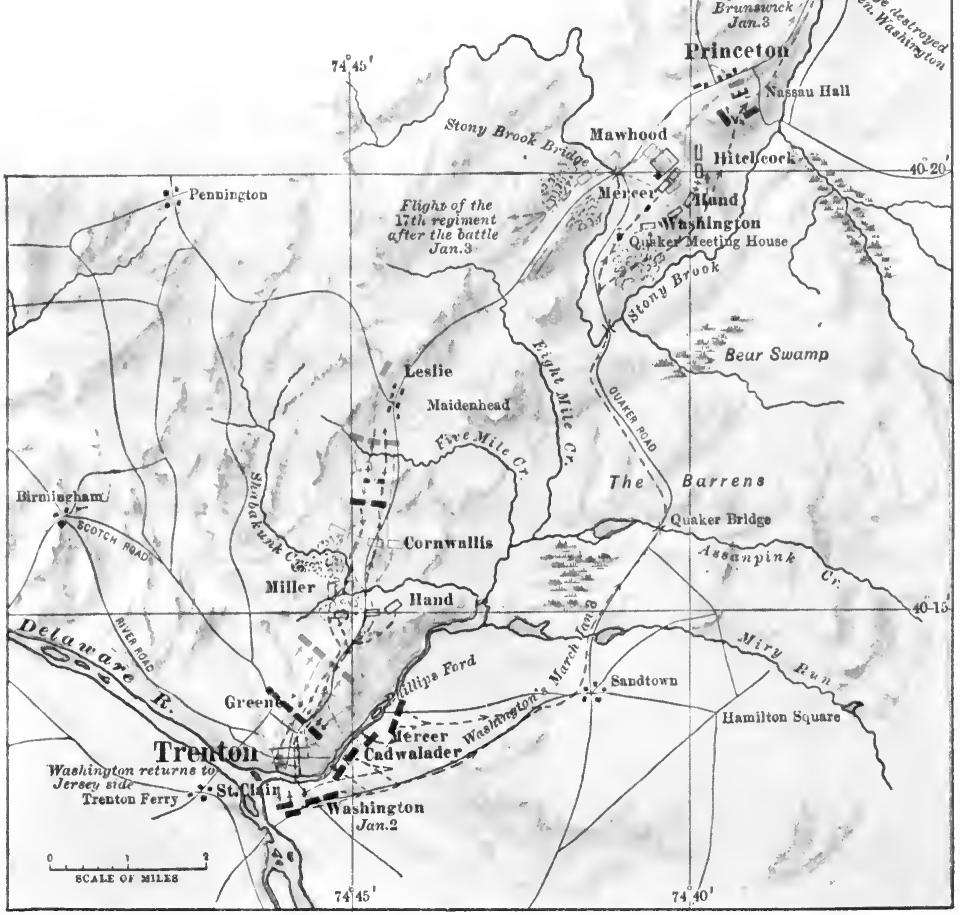

Trenton and Princeton

Jan. $2-4,1776$ 

road, and Greene's division (which Washington accom1776 panied in person) on the Scotch, about two miles to the left. The two roads entered the village of Trenton from the south-east and north-west, and, uniting, formed its main street. Artillery, to the number of eighteen pieces, was distributed through the two columns. Knox was to have charge of the crossing, and the boats were to be manned by Glover's Marblehead regiment. "A profound silence to be enjoined, and no man to quit the ranks on the pain of death." 1

The movement began soon after dark. "The floating Dec. 25 ice in the river made the labor almost incredible. However, perseverance accomplished what at first seemed Knox's Letter of Dec. 28 impossible. About 2 o'clock the troops were all on the Jersey side; we were then nine miles from the object. The night was cold and stormy; it hailed with great violence; the troops marched with the most profound silence and good order." 2 The Hessians had duly celebrated Christmas and were sound asleep. The troops "arrived by two routes at the same time, about half an hour after daylight, within one mile of the town. The storm continued with great violence, but was in our backs, and consequently in the faces of the enemy. About half a mile from the town was an advanced guard on each road, consisting of a captain's guard. These we Battle of forced, and entered the town with them pell-mell." Trenton Rall and his officers were rudely awakened in the gray Dec. 26 dawn of this cheerless morning-but by a distinguished company. Washington was with the head of column, Greene by his side, and the advance party was a company of the Third Virginia, whose officers were Captain William

${ }^{1}$ Washington's order of December 25, Stryker, 114.

${ }^{2}$ Knox, 36. 
1776 Washington and Lieutenant James Monroe, then less than eighteen years old, afterward President of the United States. Knox was directing the artillery, and among its officers was Captain Alexander Hamilton, whose twentieth birthday would come in a few days. The artillery was being brought into position to fire down King (now Warren) Street, and Greene was moving his infantry down a parallel street, and extending his right to connect with Sullivan, who simultaneously began the attack. The Hessians attempted to bring two guns into action, but the Virginia company charged them and captured the guns, both Captain Washington and Lieutenant Monroe being badly wounded in the mêlee. ${ }^{1}$

It had been a part of Washington's plan that Ewing, with a small brigade of militia was to cross at Trenton ferry, just below the village, and Cadwalader with his Pennsylvania militia at Bristol ferry, about ten miles lower down; but neither of them could cross on account of the ice. The river road from Trenton to Bordentown was thus left open, and when the Hessians turned out into the streets in some confusion, a portion of them, about 500 in number, who were attacked by Sullivan, made their escape by this road. Rall tried to form the rest in the streets at the north end of the village, but these were commanded by artillery, and he therefore moved out of the village to the east, intending to escape to Princeton. The movement was detected, and Greene quickly threw out Hand's regiment of riflemen on his left flank as far as Assanpink Creek, cutting off all escape in that direction. Rall then called upon his gren-

${ }^{1}$ The monograph by W. S. Stryker on the Battles of Trenton and Princeton is of the same character as those of Frothingham and Johnston; and one general reference to it seems to be sufficient. 
adiers to follow him in attack at the head of King Street; but he fell mortally wounded, and the rest thereupon surrendered. They numbered 32 officers and 886 men, and about 30 had been killed. The American loss was 2 privates frozen to death during the night march and 2 officers and 1 private wounded. ${ }^{1}$

Washington thought best not to push on immediately to Princeton (as it is said Greene and Knox advised), ${ }^{2}$ but to retire to the west bank of the river with his prisoners, which he did the same evening. The Hessians who had escaped to Bordentown so alarmed Donop that he immediately retreated to Amboy, and Cadwalader, who had succeeded in crossing at Bristol, occupied Borden- Dec. 27 town. He had with him about 1,800 militia, ${ }^{3}$ and more were on their way to join him from Philadelphia, where they had been raised by the exertions of Mifflin.

The terms of enlistment of Washington's entire force expired in three days, but by promising them a bounty Washington Takes the of ten dollars in addition to their regular pay he persuaded them to remain six weeks longer. He then wrote ${ }^{4}$ to the commanding officer at Morristown authorizing him to make the same arrangements with the four regiments at that place, and to Heath ${ }^{5}$ at Peekskill instructing him to march to Morristown, as he was satisfied that Howe would not attempt anything against the Highlands in the dead of winter. He then made his plans to take the offensive-a most daring plan considering the weather, his deficiency in equipment and transportation, the absence of any cavalry in his command and the fact that the enemy largely outnumbered him and was composed

'Sparks, IV, 247.

Dawson, 204; Sparks, IV, 255.

Ibid., IV, 249.
2 G. W. Greene, I, 300.

'Sparks, IV, 253. 
1776 of regular troops. Washington recrossed the Delaware, the operation requiring two days, owing to the large masses of floating ice in the river. At the same time he ordered Mifflin ${ }^{1}$ and Cadwalader, whose combined forces of militia now amounted to 3,600 men, to join him, and he took a position on the hills behind Assanpink Creek, just east of Trenton, facing west.

1777 Cornwallis, as soon as he heard of the affair at Trenton, abandoned his idea of a leave and hastened back to his main command at Brunswick. ${ }^{2}$ He immediately pushed forward toward Trenton, and with the greater part of his force, probably 6,000 men, arrived in front of the Assanpink position. There was a vigorous cannonade on both sides, but the creek was not fordable, the bridge was well guarded and the day was near its close. Cornwallis decided to postpone his attack until the next day, when two brigades which were bivouacking that night on the road between Princeton and Trenton would join him. As in the retreat from Long Island, so now in the advance to Princeton, Washington displayed that marvellous celerity which he always showed in a critical situation. At dusk he sent his baggage down the river to Burlington; large camp-fires were lighted and kept burning all night, and by their light men could be seen working at the intrenchments. At midnight his entire force withdrew, Sullivan in the lead, and making a wide détour to the east, marching about eleven miles during the night, early in the morning he struck Colonel Mawhood's brigade of three regiments, on the road just south of Princeton. ${ }^{3}$ They had broken camp and were just starting for Trenton to join Cornwallis. Mawhood turned his leading

${ }^{1}$ Sparks, IV, 258.

${ }^{2}$ Howe's Report, Dawson, 210.

${ }^{3}$ Sparks, IV, 259. 
regiment (17th) and made a violent attack upon Mercer's brigade, which was at the head of Sullivan's column. After the first discharge of guns on both sides the British charged with the bayonet, and as few of Mercer's men had any bayonets, they fell back in some confusion. Then, as at Kip's Bay, Washington rushed into the thick of the fight, and this time he succeeded in rallying the fugitives. ${ }^{1}$ It was a fight at very close quarters for about fifteen minutes; General Mercer, Colonels Haslet and Potter, and several other officers were killed. Washington escaped unharmed, and bringing up Hand's and Hitcheock's and Poor's and Patterson's and Reed's regiments, all veterans of every engagement since Bunker Hill, he overpowered the 17th Regiment. After losing nearly half its strength, ${ }^{2}$ the rest of this regiment fought its way through to the road leading south toward Trenton and escaped. The other two regiments, 40th and 55th, were thus cut off from the 17th and from their brigade commander. They made a stout resistance; but Washington, bringing up his entire strength, drove them back through the village and the college grounds at Princeton to and across a small stream called Millstone River. They continued their retreat to Brunswick; while Washington after giving a few hours' rest to his men, who had been marching and fighting for nearly forty continuous hours, turned to the left and marched a few miles up the river and halted for the night. ${ }^{3}$

Cornwallis had discovered early in the morning that Washington had evacuated his lines at Trenton, and he turned back on the same road over which he had advanced on the previous day, and marched rapidly toward

${ }^{1}$ Marshall, I, 132; Lossing, II, 32.

' Howe's Report; Dawson, 211.

${ }^{3}$ Sparks, IV, 261. 
1777 Princeton. Washington had not neglected to destroy the bridges over Stony Creek and Millstone River, and Cornwallis was delayed so long in repairing these that the whole day was spent in covering the ten miles

Jan. 4

Jan. 7

Washington Arrives at Morristown

Howe Withdraws from New Jersey to Princeton. The next day Washington marched seventeen miles in the direction of Morristown, crossing the Raritan near Bound Brook, and selecting a good position for the night in the hills near Pluckamin. Remaining there two days, he marched to Morristown and went into winter quarters with the troops already there, and with Heath's troops from the Highlands and Lincoln's militia from New England, who soon joined him. ${ }^{1}$ Cornwallis did not follow or molest him either at Pluckamin or Morristown. On the contrary, Washington sent out detachments which had skirmishes with convoys on the lines of communication of both the British and Hessians, in which they were successful. Howe was apparently so stupefied at Washington's audacity that he withdrew entirely from Jersey, except for a few miles along the Raritan from Brunswick to Amboy, and made no movements of any importance for nearly six months.

Washington's losses at Princeton were never accurately reported, but they included 10 officers, most of them of high rank, and 30 men killed, and probably 100 wounded. ${ }^{2}$ Howe reported ${ }^{3}$ his loss at 19 killed, 58 wounded and 1,000 missing; but of the latter about 100 were killed and 300 or more subsequently found their regiments-so that his actual loss was probably about 700 , or five times as great as Washington's.

To military students no page in history is more interesting, more worthy of study in every detail, than that

'Sparks, IV, 264, 272.

2 Dawson, 208.

${ }^{3}$ Howe's Report, Dawson, 208; Stryker, 458. 
which records the events of those fourteen days in Jersey, from Christmas, 1776, to Wednesday, January 7, 1777. Washington had in very truth "snatched victory out of the jaws of defeat." The planning of such an audacious Results of Trenton and stroke, the skill with which every feature of it was executed with ill-trained, half-clad, and barefooted troops, the personal gallantry of the commanding general at a critical moment-all denote the great soldier. Washington's reckless exposure in the hand-to-hand encounter on Stony Creek was on a par with that of Napoleon at Lodi and of Skobeleff at Plevna; it was designed with the same purpose, and it produced the same effect, of endearing him to his men.

The astounding but well-deserved results of the whole movement at once and forever established Washington's reputation as a soldier. ${ }^{1}$

${ }^{1}$ Lossing makes the statement (II, 33) that Frederick the Great said: "The achievements of Washington and his little band of compatriots between the 25th of December and the 4th of January, a space of ten days, were the most brilliant of any recorded in the annals of military achievements." Stryker copies this (p. 464) but without giving any authority.

There is also a mythical story, widely believed, that Frederick sent a sword to Washington with an inscription engraved upon it, "From the oldest soldier in Europe to the greatest soldier in the world."

Both stories are entirely without foundation. They have been exhaustively examined and disproved by the State Historian of New York (Preface to New York and the War with Spain, 1903), Moncure D. Conway (Century Magazine, April, 1901), Leland Haworth (American Historical Review for April, 1904, IX, 460-478), Edward J. Lowell (Hessians, 53-55). These researches prove that Frederick, while despising his relatives for selling their subjects "to the English as one sells cattle to be dragged to the shambles," showed no sympathy for the Americans in their struggle, and expressed no opinion about Washington. In a letter, dated June 23, 1777, to his brother, Prince Henry, he said, "I purpose to draw out this negotiation [with the American agent, Arthur Lee] in order to fall in with the side for which Fortune shall declare herself" (Amer. Hist. Rev., IX, 466). 
Nor were the political effects less important. It not only stopped all of Howe's operations for six months, but it laid the foundation for the French alliance. 


\section{PHILADELPHIA}

From his position at Morristown, Washington threat1777 ened Howe's flank in case the latter moved either toward Philadelphia or up the Hudson. His own communications were open via Peekskill to New England and via Advantages of Washington's Trenton to Philadelphia. He continued during the winter to send out small parties to harass the British troops on the Raritan and prevent their obtaining supplies, so that speedily Howe and his staff as well as his soldiers, although in possession of the best harbor and one of the largest cities on the Atlantic coast, were reduced to the salt provisions that they obtained from England.

Washington then addressed himself to the annual task of raising a new army, for which Congress by its resolution $^{1}$ at Baltimore had given him practically unlimited powers. In spite of extraordinary energy on Washing1776 ton's part, recruits came in slowly. The 88 battalions Dec. 27 authorized by one resolution ${ }^{2}$ and the 16 battalions of sept. 16 infantry, 3 regiments of artillery and 3,000 light horse authorized by another, ${ }^{3}$ amounted in all to nearly 76,000 Dec. 27 men. Months after these resolutions had passed Wash1777 ington reported to Congress ${ }^{4}$ that his force in Jersey was March 14 less than 3,000 fit for duty, all but 981 of whom were

${ }^{1}$ Jour. Cont. Cong., VII, 1043-1046; Sparks, IV, 550.

2 Jour. Cont. Cong., V, 762.

3our. Cont. Cong., VII, 1043-1046; Sparks, IV, 550.

'Sparks, IV, 364. 
1777 militia. About 1,000 at a time were being passed through the hospitals for inoculation against small-pox, for Washington had wisely determined that his army should not be destroyed, as the army in Canada had practically been, by that dreaded disease. Later on, however, the new regiments began to come forward, and he had 43 regiments, from New Jersey, Pennsylvania, Delaware, Maryland and Virginia. They were organized into 10 brigades and 5 divisions, under Sullivan, Greene, Stirling, Stephen and Lincoln. They numbered 8,378 officers and men. ${ }^{1}$ Other regiments, from New York and New England, were assembled under Putnam at Peekskill, whence they could move toward Albany or Morristown, as circumstances might require.

The difficulty about arms, which at one time was very serious, because the men as their enlistments expired carried their guns home with them and refused to give them up, had been fortunately solved by the arrival of vessels from France bringing 23,000 muskets ${ }^{2}$ and 1,000 barrels of powder, in addition to blankets and other military stores.

Howe's Plans

As the months wore along Washington gave incessant thought to what Howe's plans would probably be; and he was convinced that Howe would bring the troops from the St. Lawrence to join him at New York, attack Washington with all his strength, and if he succeeded push on to Philadelphia.

1776 While this was obviously the proper military plan for Howe to follow, yet Howe had different ideas in mind. He conveyed these to Lord George Germain in a long letter, which expressed the "hope of finishing the war in one year." He assumed that the army in Canada would

${ }^{1}$ Sparks, IV, 432; Marshall, I, $145 . \quad$ ' $\quad$ Sparks, IV, 338, 375. 


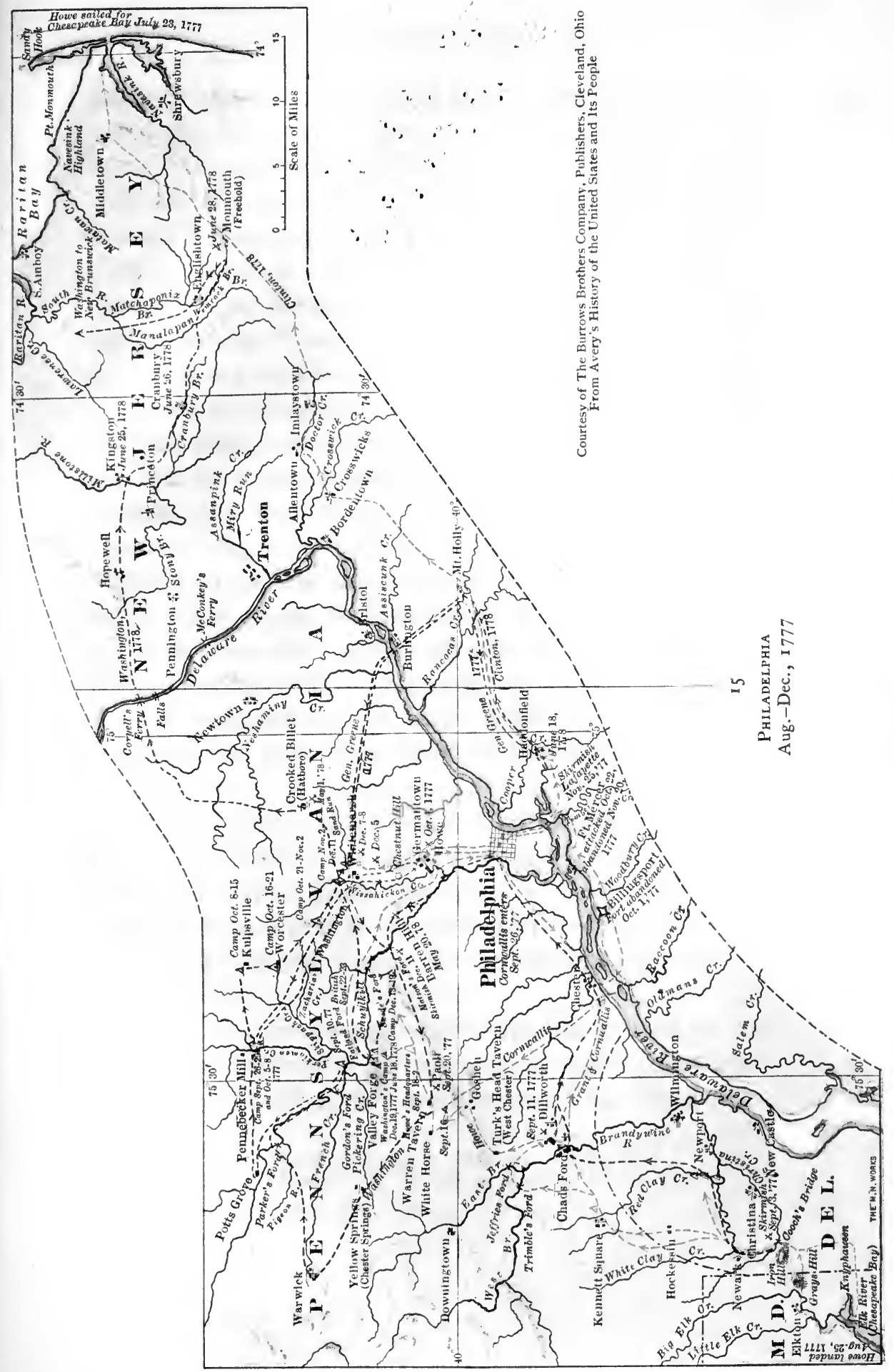




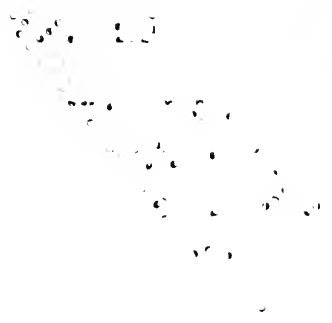


advance against Albany, and for his own troops he proposed the following: " "1st, an offensive army of 10,000 men," to move from Providence and attack Boston; "2d, an offensive army of 10,000 men," to move up the Hudson to Albany, leaving 5,000 to defend New York; " $3 \mathrm{~d}$, a defensive army of 8,000 men," to be stationed in Jersey. After the movements against Boston and Albany had succeeded the entire force was to be united in Jersey for an attack on Philadelphia-the campaign to end the following winter in Virginia and the Carolinas. To carry out this programme he asked for 10 additional ships of the line, and reinforcements of 15,000 more troops, suggesting that they might "be had from Russia or from Hanover, and other German states."

A few weeks later Howe modified his views, and wrote Dec. 20 to Germain ${ }^{2}$ saying that sentiment was changed in Pennsylvania, that the people were anxious for peace; he therefore proposed to abandon the operations against Boston and Albany; to leave 2,000 men in Newport, 4,000 men at New York, 3,000 on the Hudson, and with his main body of 10,000 effectives to act offensively in Jersey and take Philadelphia. Charles Lee had been a prisoner in Howe's hands for five days prior to the date of this despatch. Under the threat of being treated as a deserter, he had told Howe all he knew-and more. The news of the alleged change of sentiment in Pennsylvania quite probably came from him.

When these despatches reached London, Burgoyne was again there on leave of absence, and he offered his advice. His plan $^{3}$ was for a movement across Lake Champlain;

${ }^{1}$ Howe's Narrative, 9; Amer. Archives, 5, III, 926.

${ }^{2}$ Howe's Narrative, 10, 11; Amer. Archives, 5, III, 1317.

${ }^{3}$ Burgoyne, Appendix, iii-xii. 
1777 a movement from Oswego across Oneida Lake and down

Feb. 28

Burgoyne's Plan

March 27

March 9

April 2

March 29 the Mohawk River; and a movement up the Hudsonall three to be directed against Albany. This plan was submitted to King George, who wrote on it an endorsement in his own hand, ${ }^{1}$ giving it his general approval; he rejected the suggestion that the troops in Canada might be brought to join Howe at New York, saying, "I greatly dislike that idea"; he also said explicitly: "The force from Canada must join him (Howe) at Albany." This plan was therefore the one adopted so far as the London authorities were concerned; Burgoyne was selected to command the two expeditions from Canada; and he left London, carrying a despatch to Sir Guy Carleton, ${ }^{3}$ the Governor of Canada, to that effect. No definite instructions were sent to Howe, but he was informed by a despatch, ${ }^{4}$ which reached him before the orders were given to Burgoyne, that it was not thought necessary to send him so large a reinforcement as 15,000 men; that a smaller number would be sent; and no objection was made to his plan to proceed against Philadelphia.

Howe's despatch of December 20 (above quoted) had stated his intention to attack Philadelphia by the direct route through Jersey; but later he changed his mind and devised a third plan. He outlined this in a confidential despatch ${ }^{5}$ to Germain, written four days after Charles Lee had put in his hand a written memorandum of the conditions as Lee thought they existed in the Central and Southern States, and a plan of campaign based on these

${ }^{1}$ The King's endorsement in full is given in Fonblanque's Burgoyne, 487.

${ }^{2}$ Ibid.

${ }^{3}$ Germain to Carleton, Burgoyne, Appendix, xii-xvii.

- Germain to Howe, Howe's Narrative, 12.

${ }^{5}$ Howe to Germain, Ibid., 13. 
assumptions. Lee argued $^{1}$ that there was a strong tory sentiment in Pennsylvania and Maryland, and that the Lee's Plan proper line of attack upon Philadelphia was by way of the Chesapeake. While this written proposition of Lee's, as previously stated, never came to light until eighty years afterward, and was not referred to in any way by Howe, it seems to have been the basis of the plan which he adopted.

The extraordinary spectacle was thus presented of a subordinate general going to London and getting the King's approval to one plan of campaign; of the King's minister sending full instructions to one general and none to the other who was to co-operate with him; and of this other general making his own independent plan on the advice of a prisoner, who had turned traitor to the country whose uniform he then wore. This confusion of plans led to the complete surrender of one British army, and the ultimate failure of the other; it was a factor of the highest importance in the ultimate success of the American cause.

The military situation was, in a striking degree, similar to that in front of Washington eighty-five years later. When McClellan left Johnston at Manassas and went by Military Situation at the Beginning of a circuitous route to the Peninsula he found Johnston facing him on his arrival; and when Howe left Washington in Jersey and travelled 400 miles to the Head of Elk he found Washington drawn up to meet him. At the Head of Elk, Howe was 70 miles from Philadelphia, whereas he had been only 60 miles from it at Brunswick; and the same enemy and same commander opposed him, after he had consumed two months of the best season of the year in making the change. Had

${ }^{1}$ Moore, 88-89. 
1777 Howe adopted a plan similar to that of Grant's in 1864, and insisted on the troops in Canada being sent to join him at New York; and with the combined force of nearly 35,000 regulars had he attacked Washington's 8,000 newly raised Continentals with the same fierceness that was shown in the Wilderness, it hardly seems possible that Washington, fertile as he was in resources, could have saved the Revolution from being crushed in the spring of 1777. But, as stated on a previous page, Howe never recovered from the mental paralysis which he received at Bunker Hill.

April 24

Raid into Connecticut

While Washington was at Morristown, keenly watching for every move of his adversary, Howe made a raid into Connecticut. Governor Tryon (tory governor of New York) with 2,000 men landed at Fairfield, marched up to Danbury, destroyed a large amount of stores which the Americans could ill afford to lose, encountered the militia under Arnold and Wooster in a sharp engagement at Ridgefield (in which Wooster was mortally wounded) and then returned to New York. This raid had no effect on the campaign, and it cost the British a loss of about 200 in killed and wounded. ${ }^{1}$

Washington Moves to

Washington meanwhile kept his eye unceasingly on Middlebrook Howe, and being more than ever convinced that the latter would move toward Philadelphia, he broke up his May 29 camp at Morristown and moved about twenty miles south to the Raritan River, so as to be nearer Howe's line of march. Here he occupied a strong position, which Greene had selected, on the heights of Middlebrook, just back of Bound Brook, about ten miles from Brunswick. His right under Sullivan was sent out as far as Princeton. Then followed two months of extremely

${ }^{1}$ Dawson, 213-219; Sparks, IV, 404-406. 
Courtesy of The Burrows Brothers Company, Publishers, Cleveland, Ohio

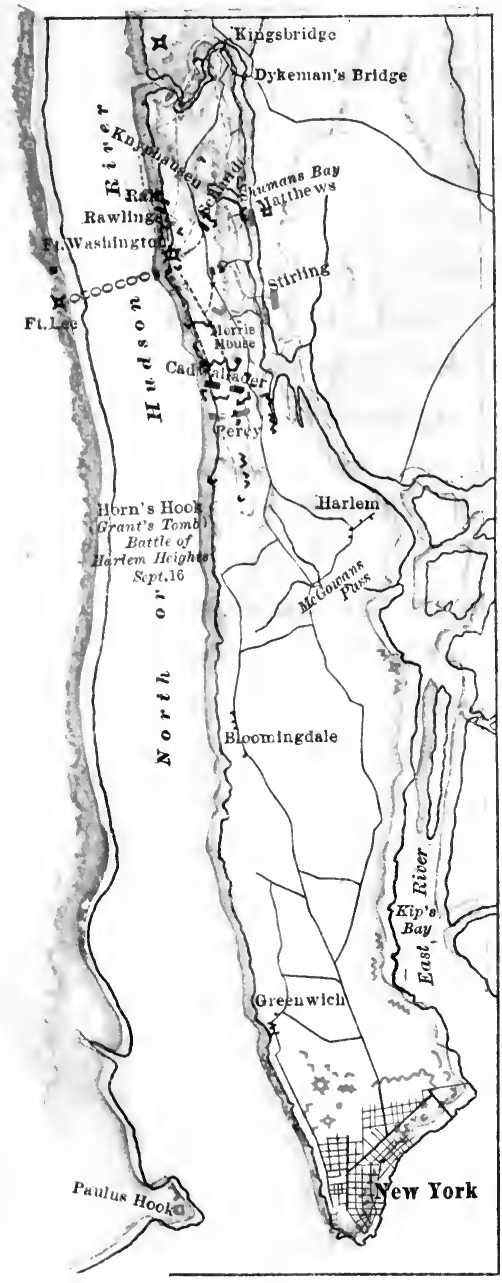

ForT WASHINGTON

Nov. 16,1776 ,$\cdot \ldots$

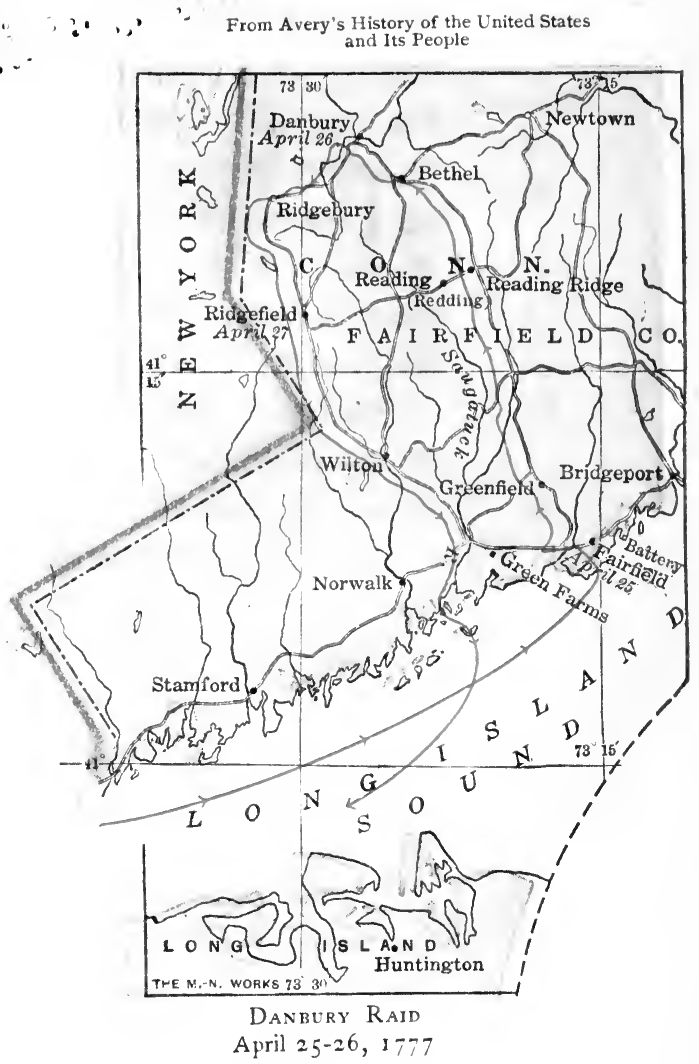




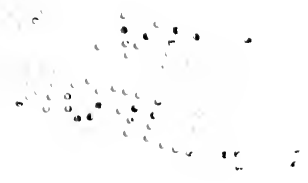


interesting manœuvres, carried out on both sides with 1777 excellent skill. First, Howe tried to manœuvre Washington out of the strong Middlebrook position, and get him down in the lower open country where he could attack him to better advantage. He therefore crossed the Raritan with about 10,000 men and placed himself between Washington and Princeton-on the road to Philadelphia. Washington did not leave his position. He doubted, as he wrote Schuyler," whether this was "a June 16 real move toward Philadelphia"; if it should so prove, he intended to let Howe get as far as the Delaware, where he would meet with opposition from the militia in his front, and then follow rapidly, cut his communications and attack his rear. Washington having correctly interpreted Howe's first move, it failed. ${ }^{2}$

Howe's second move was somewhat more successful. June 23 He retreated suddenly to Amboy, hoping thus to tempt Washington out of his strong position, and then turn Howe's Second Manœuvre sharply and attack him. The bait was too tempting; Washington sent Greene with three brigades in pursuit, and himself followed Greene with his entire force. Greene did not advance more than five miles beyond Brunswick, not wishing to get too far from the main body, but Stirling on his left advanced almost to Staten Island Sound. ${ }^{3}$

Then Howe made his third manœuvre. He had taken part of his troops across to Staten Island; he now suddenly recrossed the Kills, drove Stirling back in some Howe's Third Manœuvre confusion, and marched rapidly to Westfield, several miles west of Rahway. He was thus on Washington's left flank, threatening his communications with the Hudson. He hoped that Washington would attack; but
${ }^{1}$ Sparks, IV, 462.
${ }^{2}$ Ibid, IV, 469.
s Ibid., IV, 470, 473. 
Howe Sails for the Chesapeake

July 7 July 21

Washington Marches Southward

Washington returned quickly with his whole force to the Middlebrook lines. ${ }^{1}$

The third manœuvre having thus failed, Howe returned to Staten Island, put his troops on board transports and men-of-war, 228 in number, and proceeded to carry out his main purpose of transporting his army to the south of Philadelphia.

Washington knew that the troops were on board and that the ships had dropped down to the lower bay; ${ }^{2}$ but he could not learn positively that they had sailed. At the same time came reports from Schuyler at Albany and Putnam at Peekskill which led him to believe that Howe intended to move up the Hudson. Burgoyne had crossed Lake Champlain, captured Crown Point and Ticonderoga and was advancing rapidly on Albany. It might be that Howe would suddenly bring his ships back from the lower bay or from outside and sail up the Hudson to join Burgoyne at Albany. Washington therefore ordered Putnam to send two brigades to reinforce Schuyler, made arrangements to collect shipping to move his own troops up the Hudson, if necessary, and marched in that direction himself; first to Morristown, then to Ramapo and then to the Clove (near Haverstraw Bay), and he sent two divisions (Sullivan's and Stirling's) to cross the Hudson at Peekskill. After being three days in the Clove

July 24 he received positive information that Howe's fleet had gone to sea. He rightly surmised that their destination was the Delaware, and he promptly put his army in motion to the southward, recalling Sullivan and Stirling to Morristown. The new battalions had been gradually

${ }^{1}$ Sparks, IV, 475.

${ }^{2}$ Washington's despatches to the President of Congress and others describing his perplexities during these anxious seven weeks are given in Sparks, IV, 479-505; V, 1-44. 
filling up and his force numbered now about 14,000 men. ${ }^{1}$

When Washington reached the Delaware River he July 30 halted until he should hear of Howe's arrival in the Delaware Bay. News of this came the next day, and he resumed his march to the south, pushing on himself as July 31 far as Chester, to reconnoitre. There he learned that Aug. 1 Howe's fleet had remained only a day in the Delaware and had put to sea again. He halted the army in the vicinity of Philadelphia, and ordered Sullivan's and Stirling's division (which had remained at Morristown) to march back to Peekskill. Nothing was heard of Howe's fleet for three weeks. During this time Washington had moved northward again to the vicinity of the Delaware; and a council of war was unanimously of opinion that Aug. 21 Howe had gone south to Charleston, that it would be useless to follow him there, and the army should move to the North River, with a view possibly to its marching to Albany. But the next day came authentic information aug. 22 that Howe's fleet was at anchor in the Chesapeake. ${ }^{2}$ Washington put his troops, "harassed by marching and countermarching," as he wrote to his brother, ${ }^{3}$ again in motion to the southward; marched through Philadelphia

\section{Washington} Marches South through Philadelphia with colors flying and drums beating on a Sunday morn- Aug. 24 ing, exciting no little admiration and animating the militia to turn out, and reached Wilmington the follow- Aug. 25 ing day. Taking Greene and Lafayette (who had just Howe's army arrived from France, been commissioned a major-general, of Elk

${ }^{1}$ Lossing, I, 331.

${ }^{2}$ Howe embarked his troops (18,000 in all) July 5, sailed July 23, reached the capes of the Delaware July 30, sailed from there the same day, passed the capes of the Chesapeake August 16, and landed at Head of Elk August 25. Howe's Narrative, 23, 24.

${ }^{3}$ See foot-note 2 , previous page. 
1777 although a few days less than twenty years old, and joined the army) and a small escort, Washington rode forward nearly twenty miles on a personal reconnoissance, and from a high hill near the Head of Elk saw the British camp. He decided to post his army behind a small creek about eight miles south of Wilmington and accept battle. Howe, after making a feint against this position, moved past Washington's right flank with the intention of crossing the Brandywine, ${ }^{1}$ seizing the high ground behind the Brandywine and cutting off Washington's communications with Philadelphia or forcing him to fight at a disadvantage. But Washington promptly detected the movement, ${ }^{2}$ retreated to Wilmington, crossed the Brandywine, and marching twelve miles up its eastern bank Sept. 10 took position at Chad's Ford. Greene with his own division and two other brigades was in the centre, opposite the ford; Sullivan with his division and those of Stirling and Stephen was posted about two miles up the creek with instructions to guard the fords as far as the forks of the Brandywine; and Armstrong, with the Pennsylvania militia, guarded the fords on Greene's left. The total force was about 11,000 men. ${ }^{3}$

Sept. 10

Howe's Plan of Attack

On the same evening Howe halted at Kenneth Square, about eight miles south of Chad's Ford.

Howe's plan for the ensuing battle was substantially the same as at Brooklyn, and if Washington had not been present in person, with Greene at hand to carry out his orders, it would probably have succeeded. He directed the Hessians to advance to Chad's Ford and make a feint of attacking there, while the larger part of his army under Cornwallis was to march up the Brandywine,

1 The Brandywine empties into the Delaware at Wilmington.

${ }^{2}$ Sparks, V, 56.

${ }^{3}$ Dawson, 278. 


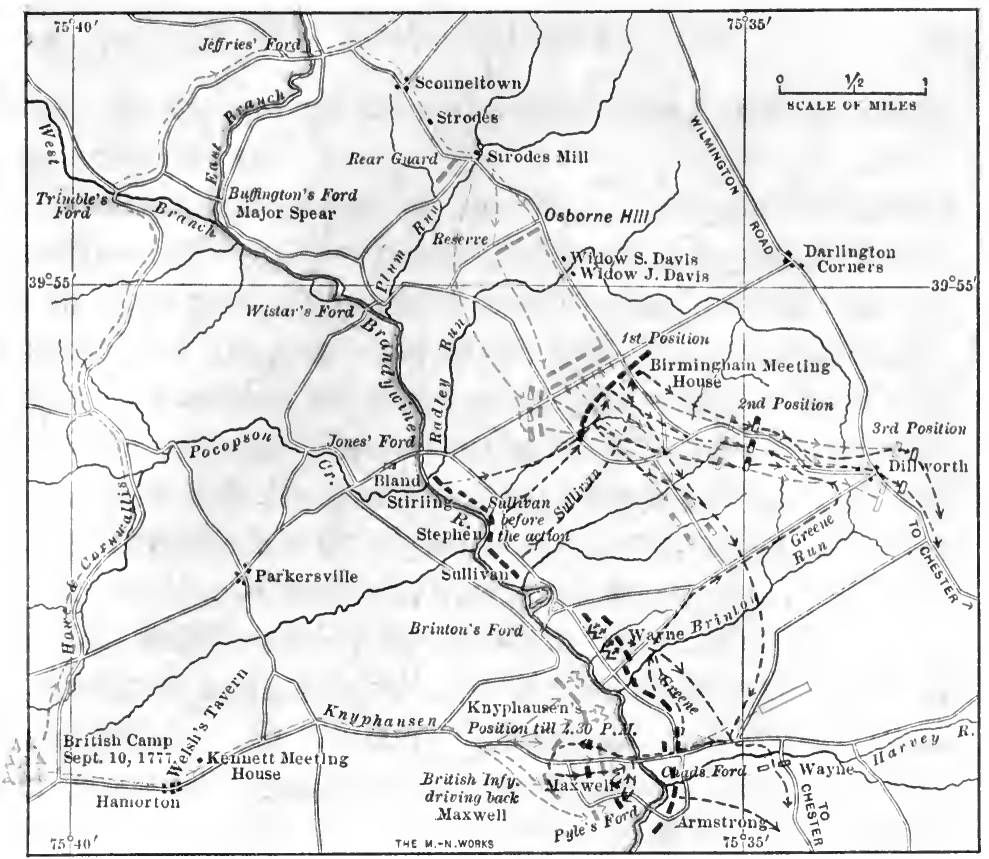

BRANDYWINE

Sept. I I, I 777

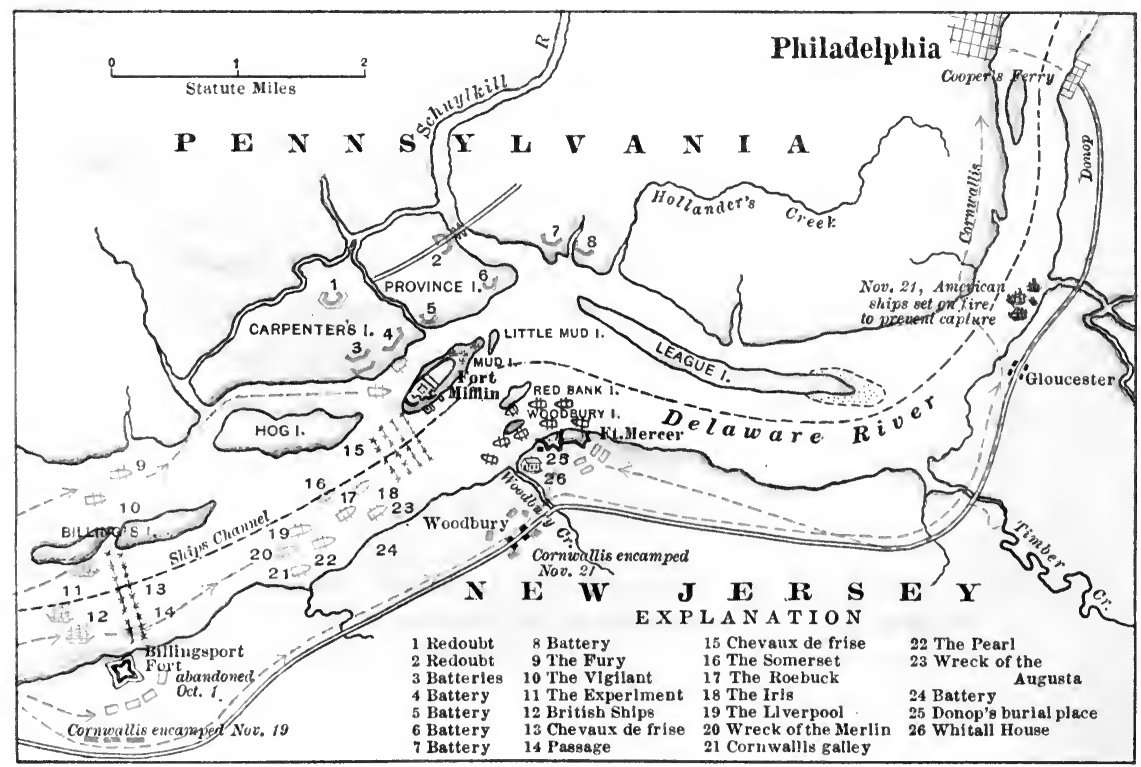
Courtesy of The Burrows Brothers Company,
Publishers, Cleveland, Ohio 
. 
cross the stream at the forks and come down in rear of the American position. ${ }^{1}$

Howe's army moved at daybreak. Knyphausen with sept. 11 his Hessians and two British brigades, about 5,000 men in all, marched on the direct road to Chad's Ford, arriving Battle of the there about $10 \mathrm{~A}$. M. He drove back the American outBrandywine posts and carried on quite an active artillery duel with Greene's batteries posted on the heights behind the ford; Cornwallis with the greater part of the British troops and some Hessians, about 10,000 men all told, marched twelve miles up the Brandywine, crossed the forks, and then turning southward came squarely in rear of Sullivan's division, posted behind Jones's Ford, almost without firing a shot. ${ }^{2}$ In the four hours which had elapsed since Knyphausen began skirmishing at Chad's Ford, Sullivan had received from his "light parties" and had transmitted to Washington contradictory information concerning the enemy's movements. The first report ${ }^{3}$ was that a large body of the enemy was marching to the westward a few 11 A. $\mathbf{~ . ~}$ miles from the Brandywine; Washington immediately ordered Sullivan to cross the creek and attack that body in flank, while he in person joined Greene and made preparations to cross above Chad's Ford and cut off Knyphausen from the rest of Howe's army. Before these plans could be carried into effect, Sullivan received word from a scouting party at the forks of the Brandywine that there was no appearance of the enemy in that neighborhood. He thereupon discontinued his movement, and so reported to Washington, who coun-

${ }^{1}$ Howe's Report, Dawson, 281.

${ }^{2}$ Ibid., 282.

${ }^{3}$ Sullivan was much criticised for his conduct at the Brandywine. His defence, accompanied by copies of the reports from the "light parties," is given in full in Sparks, V, 456-463. 
termanded the orders to Greene. Later came a definite report that the British could be plainly seen forming on Osborne's Hill, about a mile or more in rear of Sullivan and to his right. Sullivan promptly withdrew his division from the creek, changed front to the right and formed line across the main road at the Birmingham meeting-house. His troops were hardly in position when Cornwallis attacked him with great violence. The fighting around the stone meeting-house (which is still standing) was very fierce. Sullivan was greatly outnumbered, and his three divisions in succession gave way, Stirling making the most stubborn resistance. Finally both were overwhelmed, and the retreat became a rout. Two of Sullivan's aides were wounded, and Lafayette got a bullet hole in his leg which laid him up for several weeks. ${ }^{1}$

Washington had meanwhile received the report from Sullivan $^{2}$ of the appearance of the British in his rear; he ordered Greene to leave Wayne to defend Chad's Ford, and with his other brigades (Muhlenberg's and Weedon's) to go to Sullivan's assistance. Greene lost no time, and marching his men four miles in forty-five minutes, ${ }^{3}$ he formed a line in rear of Sullivan's retreating 5 P. м. troops, opened his ranks to allow them to pass through and then opposed the British with such vigor as to halt their advance. His position was a strong one, on both sides of a narrow pass in the road, and flanked by thick woods. Repeated attacks were made by the British, but they could not dislodge him, and Greene still held the position when night put an end to the firing. Mean-

${ }^{1}$ Many of the houses on the Brandywine battle-field are still standing (1911) just as they were at the time of the battle; and the Pennsylvania Historical Society has erected sign-posts indicating the movements of the troops as well as the spot where Lafayette was wounded.

${ }^{2}$ See foot note 3 , previous page. $\quad{ }^{3} \mathrm{G}$. W. Greene, I, 449. 
while, Wayne, with his small force, was unable to resist 1777 the advance of Knyphausen; the latter had crossed Chad's Ford as soon as Greene's main body had gone to Sullivan's aid. Wayne effected his retreat behind the rear of Greene's line and gained the road to Chester. During the night Greene retreated in good order and sept. 12 without molestation. In the morning the army was assembled at Chester and marched to Germantown.

The British losses were officially reported as 90 killed, 480 wounded and 6 missing. ${ }^{1}$ The Americans left their dead and wounded on the field, and no accurate report of them was ever made. Their loss was estimated at 300 killed and 600 wounded. ${ }^{2}$

In this battle Washington had about 11,000 present and Howe between 15,000 and 18,000. ${ }^{3}$ The disparity in discipline, arms and equipment was even greater. It has been often questioned whether Washington was justified in fighting a battle under these adverse conditions. On the other hand there can be no doubt that public opinion, in and out of Congress, imperatively demanded it; and had Washington retreated without a battle the effect would have been more disastrous than the defeat. It was indeed a defeat, but Washington saved it from being a rout.

Neither the army nor its commander was discouraged. After giving his men only one day's rest at Germantown, Washington boldly crossed the Schuylkill with the intent of attacking Howe, who had slowly followed him. The two armies met at Warwick Tavern, about twenty sept. 16 miles west of Philadelphia and fifteen miles from Chad's Ford. The battle did not take place. Something hap-

1 Howe's Report, Dawson, 278.

2 Marshall's Washington, I, 158.

Lossing, II, 170, 178. 
1777 pened of a nature which military commanders no longer have to take into account in making their plans. The ammunition in Washington's army, and a large part of that in Howe's, was totally ruined ${ }^{1}$ by a violent rain storm, which continued unabated during the greater part of two days. Washington had no recourse but to retreat across the Schuylkill near Perkiomen, where fresh supplies could be obtained. During this retreat the soPaoli Massacre called "Paoli massacre" occurred. Wayne's division, which constituted the rear guard, was encamped for the Sept. 21, night at Paoli Tavern. He was attacked by three regi1 A. M. ments under General Grey, ${ }^{2}$ who reached Wayne's camp without firing a shot, and used the bayonet so effectively that they claimed to have killed and wounded 300 men and to have taken between 70 and 80 prisoners, with a loss on their own side of only 4 killed and 4 wounded. ${ }^{3}$ Wayne managed to extricate the rest of his division and retreat to Chester. He was court-martialled but acquitted."

Howe Captures

After this affair Howe manœuvred against Washington's right flank, causing him to move farther up the Schuylkill; and then, suddenly countermarching, he crossed the Schuylkill at Sweed's Ford (Norristown) and placed himself between Washington and Philadelphia. Washington was not in condition to give battle, and Howe marched down the Schuylkill and took possession of Philadelphia, encamping the bulk of his troops at Germantown. As soon as Washington had obtained fresh ammunition he followed Howe and went into camp

\footnotetext{
${ }^{1}$ Sparks, V, 66.

${ }^{2}$ Great-grandfather of Earl Grey, at present (1911) Governor-General of Canada.

'Howe's Report, Dawson, 317.

'Sparks, V, 166; Dawson, 315.
} 
on Skippack Creek, about twenty miles from Germantown. ${ }^{1}$

In a campaign of thirty-two days since landing at the Head of Elk, Howe had met and defeated his enemy and Results of the gained possession of their capital, the Congress adjourning to York. He had a superiority in numbers and immense advantage in munitions and supplies. His movements were well conducted, but they lacked the final element of success; he had not destroyed his adversary's army. This army, in fact, speedily came forward to attack him, on a bold and hazardous plan, which came surprisingly near to success.

Upon taking possession of Philadelphia, Howe posted ${ }^{2}$ the greater part of his army along the line of the School Howe's House Lane, which ran through the market square of the village of Germantown, about seven miles from Philadelphia. At the market it intersected the road (Germantown Avenue) which led from Philadelphia through Chestnut Hill to the open country on the north-west, and along which for nearly two miles stretched the ancient village of Germantown. Howe's line was about three miles long, his left on the Schuylkill, his centre at the market, and his right on a small stream about a mile to the north of the market. In front of a large part of his line was the precipitous gorge of the Wissahickon, nearly 200 feet deep. His outposts were about two miles in advance, at the end of the village toward Chestnut Hill. His force numbered about $9,000 \mathrm{men},{ }^{3}$ and he had 3,000 or more in Philadelphia. The rest of his army had been detached across the Delaware River in Jersey, and on learning this Washington deemed the moment auspicious for attack. ${ }^{4}$

${ }^{1}$ Sparks, V, 73, 77; Dawson, 318.

${ }^{3}$ Lossing, 11.
${ }^{2}$ Howe's Report, Dawson, 330.

Sparks, V, 78. 
1777

Washington's Plan

Washington's Plan of Attack

His plan was somewhat similar to that which had succeeded so well at Trenton. Leaving his camp on Skippack Creek, nearly twenty miles from the Germantown market, one column under Sullivan, consisting of his own and Wayne's divisions flanked by Conway's brigade, was to follow the main road and attack the British left; another column under Greene, with his own and Stephen's divisions flanked by McDougall's brigade, was to make a détour by the Lime-kiln road and strike the British right beyond the market; the Pennsylvania militia under Armstrong was to follow the Manatawny road, on the ridge between the Schuylkill and Wissahickon, and crossing the Wissahickon at its mouth to get in rear of the British left; the Maryland and Jersey militia under Smallwood and Forman were to follow the York road, a mile or more on Greene's left, and fall upon the rear of their right. Stirling's division formed the reserve, following Sullivan on the main road through Chestnut Hill. Washington in person was with Sullivan's column. His entire force, including some troops recently arrived from Peekskill, numbered only 8,000 Continentals and 3,000 militia. The four columns were to march all night on separate roads covering a width of about seven miles, separated by broken country and deep ravines. These columns were to converge at daylight and simultaneously attack. It was indeed a bold plan.

Oct. 3 ,

7 P. M.

Oct. 4

Leaving their camps at dusk the night march was carried out as directed, and about sunrise the next morning Conway's brigade passed over Chestnut Hill, and drove in the British pickets at Mount Airy. ${ }^{1}$ These fell back on their supports, consisting of a battalion of light infantry and the 40th Regiment. Colonel Musgrave then placed 
five companies of the latter regiment in a strong stone house belonging to Chief-Justice Chew. ${ }^{1}$ They barricaded the doors, and firing through the windows they resisted every effort to dislodge them by infantry and artillery. They held this position throughout the entire battle.

Finding it impossible to capture this house, Sullivan pushed on, dividing his command, his own division on the right of the road and Wayne's on the left. The British contested every wall and garden, but were slowly forced back toward the market. The Pennsylvania militia, instead of gaining the rear of the British left, did not cross the Wissahickon, but contented themselves with firing a few shots across the ravine and then retreated. Nash's brigade from Stirling's division was then sent to protect Sullivan's right. The Maryland and Jersey militia did not come into action at all. ${ }^{2}$

The battle had been in progress for about three-quarters of an hour before Greene arrived on the left. He had a longer road to march than Sullivan, his guide lost his way, and when day broke there was a heavy fog which soon became so dense that it was impossible to see more than a few yards. ${ }^{3}$ When he did come into action, Stephen's division on the right of the Lime-kiln road fired into Wayne's division, mistaking them for the enemy in the fog. This caused confusion and led to the retreat of both divisions, uncovering Sullivan's left and Greene's right flank. The battle, however, continued for nearly two hours longer; Greene fighting his way along the Lime-kiln road and driving the British back until he reached the market house; Sullivan doing the same on

1 This house is still standing (1911) in excellent preservation; and, I believe, it is owned by the lineal descendants of Chief-Justice Chew.

${ }^{2}$ Lossing, II, 111.

${ }^{3}$ Sparks, V, 79, 83, 102; Dawson, 328, 329. 
1777 the right of the road from Chestnut Hill; and Maxwell's brigade from the reserve was still firing on the Chew house, nearly two miles behind Sullivan. Cornwallis was hastening from Philadelphia with reinforcements ; ${ }^{1}$ Howe's main body had been driven through the entire length of the village, and it is said that he was making prepara-

Oct. 4,

10 A. M., The Germantown Panic tions to retreat to Chester. ${ }^{2}$ Then occurred one of those panics $^{3}$ to which all armies are subject, and which are never explained. Possibly it was the fog; possibly the firing back at the Chew house which led the Americans to think that they were surrounded; possibly it was because their ammunition was exhausted. Whatever the cause, the retreat began suddenly at all points on their line. Seeing this, General Grant, who commanded on the British right, rallied his disorganized troops and made a vigorous attack. In spite of the personal efforts of Washington, who was again in the midst of the fight, ${ }^{4}$ the Americans gave way at all points and hastily retreated. By nightfall they reached their camps on Skippack Creek. They had saved all their artillery. Cornwallis had pursued them for five miles, skirmishing with the rear guard under Pulaski, and then abandoned the pursuit. ${ }^{5}$

Howe reported his losses as 535 killed, wounded and missing, of whom less than 100 were killed. The losses on the American side were stated by the Board of War to be 152 killed, 521 wounded and 400 missing. ${ }^{6}$ General Agnew on the British and General Nash on the American side were mortally wounded, and died a few days later. General Stephen was tried by court-martial for

${ }^{1}$ Howe's Report, Dawson, 330.

'Sparks, V, 79, 102; Dawson, 325.

${ }^{2}$ Sparks, V, 83.

-Sullivan's letter, Sparks, V, 467.

${ }^{\circledR}$ Sparks, V, 80; Wayne's letter, Dawson, 329.

'Dawson, 324. 


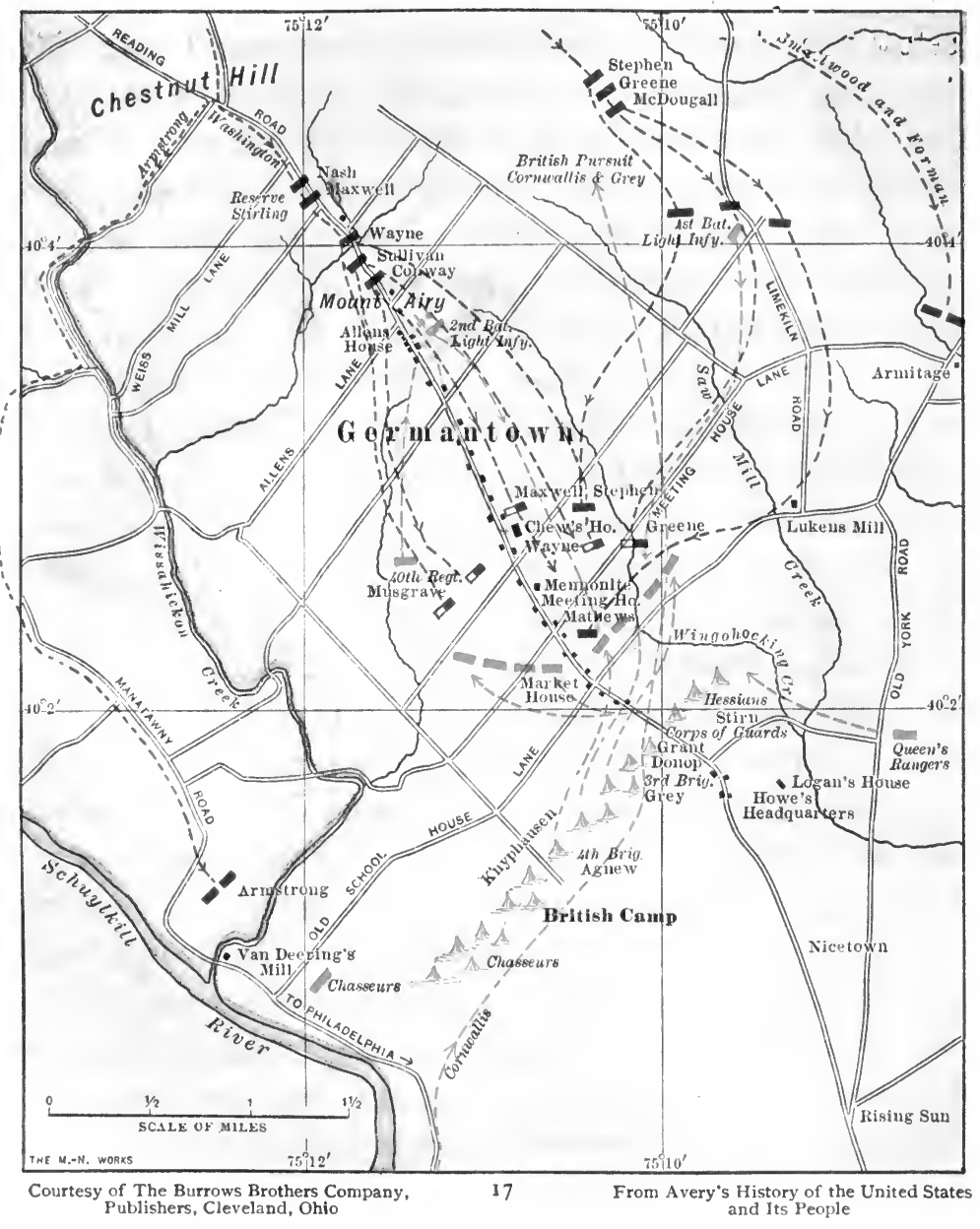

Germantown

Oct. 4, 1777 


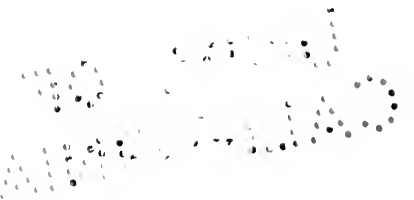


"unofficer-like conduct" and intoxication, and was dismissed. ${ }^{1}$

Washington remained in the camp on Skippack Creek oct. 29 for three weeks and then moved eastward again to the hills near the village of Whitemarsh, about four miles from Chestnut Hill. Howe came out to attack him, but after an inconclusive skirmish he decided that Washing- Dec. 5 ton's position was too strong. ${ }^{2}$ He returned to Phila- Dec. 8 delphia and went into winter quarters. Soon after Washington selected the camp at Valley Forge, twentyfive miles up the Schuylkill from Philadelphia, and Dec. 19 moved his troops there. ${ }^{3}$

In the meantime Howe had gained possession of the American forts on both sides of the Delaware near PhilaDestruction of the Forts on delphia. These works consisted of one redoubt, Fort Mifflin, on the Pennsylvania side, just below the mouth of the Schuylkill; another, Fort Mercer, opposite to it, at Red Bank, on the Jersey shore; and a third, at Billingsport, about three miles below, on the Jersey side. In addition to the redoubts, the channels of the river were obstructed by chevaux-de-frise. The redoubts were garrisoned with infantry and artillery at the time of the battle of the Brandywine. Immediately after that battle Earl Howe, ${ }^{5}$ commanding the British fleet in America, sent some of his lighter vessels from the Chesapeake around into the Delaware. In co-operation with a British regiment sent across the river at Chester, they removed oct. 6 the obstructions and captured the garrison at Billingsport. ${ }^{\circ}$

The next attempt was made against Fort Mercer, and Fort Mercer here a gallant and successful defence was made. The

${ }^{1}$ Lossing, II, 114.

S Sparks, 522-525.

- Brother of General Howe.
${ }^{2}$ Dawson, 368-373.

- Dawson, 350; Lossing, II, 85-86.

' Earl Howe's Report, Dawson, 357. 
1777 garrison consisted of two Rhode Island regiments under command of Colonel Christopher Greene. They numbered not more than 400 men. They were attacked by Count Donop and 1,200 Hessians, who had crossed the river at Gloucester (just below Camden). These made a furious assault but were completely repulsed. Donop was mortally wounded, 10 other officers and 140 men were killed and wounded and about 200 were taken prisoners. The loss in the garrison was only 14 killed and 23 wounded. ${ }^{1}$ This brilliant defence brought the warmest commendations and the present of a sword from Congress to Colonel Greene.

Fort Miftlin

Howe next turned his attention to Fort Mifflin. It was garrisoned by a Maryland regiment of 300 men under Colonel Smith, afterward reinforced by 150 Pennsylvania troops sent from Washington's camp. Instead of assaulting this, Howe reduced it by artillery. He erected shore batteries with guns taken from his brother's fleet-four 32-pounders, six 24-pounders and one 13-inch mortar. With these he kept up a vigorous cannonade for an entire

Nov. 10

Nov. 15

Fort Mercer

Nov. 20 day, inflicting heavy losses on the garrison. Next a combined land and naval attack was made, the shore batteries being reinforced by 6 men-of-war, carrying 191 guns, besides smaller vessels. The redoubt was battered to pieces, about 250 of the garrison were killed and wounded (Colonel Smith being among the latter) and the rest made their escape during the night to Fort Mercer.

Finally, Howe sent a strong force against Fort Mercer. It was commanded by Cornwallis and numbered about 5,500 men. It crossed the Delaware at Chester and marched up the east bank of the river. The little gar-

${ }^{1}$ Report of Colonel Greene, Dawson, 355; Howe's report, Dawson, 356. 
rison was unable to cope with an opposing force of this 1777 magnitude and evacuated the fort. ${ }^{1}$ Cornwallis took possession and dismantled it. Washington heard of this movement and immediately detached Greene ${ }^{2}$ with his division to cross the river at Burlington and march down to the relief of Fort Mercer; but it was too late. The fort had been evacuated the day Greene left Whitemarsh. After some unimportant manœuvring by Greene and Cornwallis, both returned to their respective camps. ${ }^{3}$

Howe was thus in possession of Philadelphia and in undisputed communication with his brother's fleet. His army remained there for seven months, absolutely inac- Nov., 1777, to tive, gradually deteriorating in discipline, its officers June, 1778 engaged in the Mischianza and other foolish gayeties. Meanwhile Washington and his half-clad soldiers were shivering and almost starving at Valley Forge.

${ }^{1}$ Washington's, Howe's and Earl Howe's Reports, Dawson, 364-367.

${ }^{2}$ Sparks, V, 167.

' G. W. Greene, I, 518-533. 


\section{CHAPTER IV}

\section{THE HUDSON}

1776 While Howe had been carrying on his Philadelphia Origin of the campaign, Burgoyne had advanced from Canada along
Campaign. the line of the Hudson, and had surrendered his entire army at Saratoga.

The circumstances under which this campaign originated, and the lack of co-operation between Howe and Burgoyne, have already been explained. ${ }^{1}$ Briefly, Burgoyne's plan contemplated a movement of tories and Indians from Oswego down the Mohawk Valley, and an advance of British regulars and Hessians from Montreal through Lake Champlain and the upper Hudson-both to unite at Albany, where Howe was to join him from New York. ${ }^{2}$ No instructions having been sent to Howe, ${ }^{3}$ that part of the plan disappeared; the other two movements were undertaken.

The force detailed to Burgoyne consisted of 3 British July 1 brigades, 3 Hessian brigades, 38 pieces of light artillery and 10 pieces of siege artillery. They numbered 7,213 rank and file. In addition there were 250 Canadians and 400 Indians; so that, counting the officers, Burgoyne had something over 8,000 men. The expedition from Oswego was commanded by Colonel St. Leger, and consisted of 900 Indians and 700 white men; the latter made

${ }^{1}$ Pp. 77-79, ante.

2 Burgoyne, Appendix IV, 13.

P. 78, ante. 


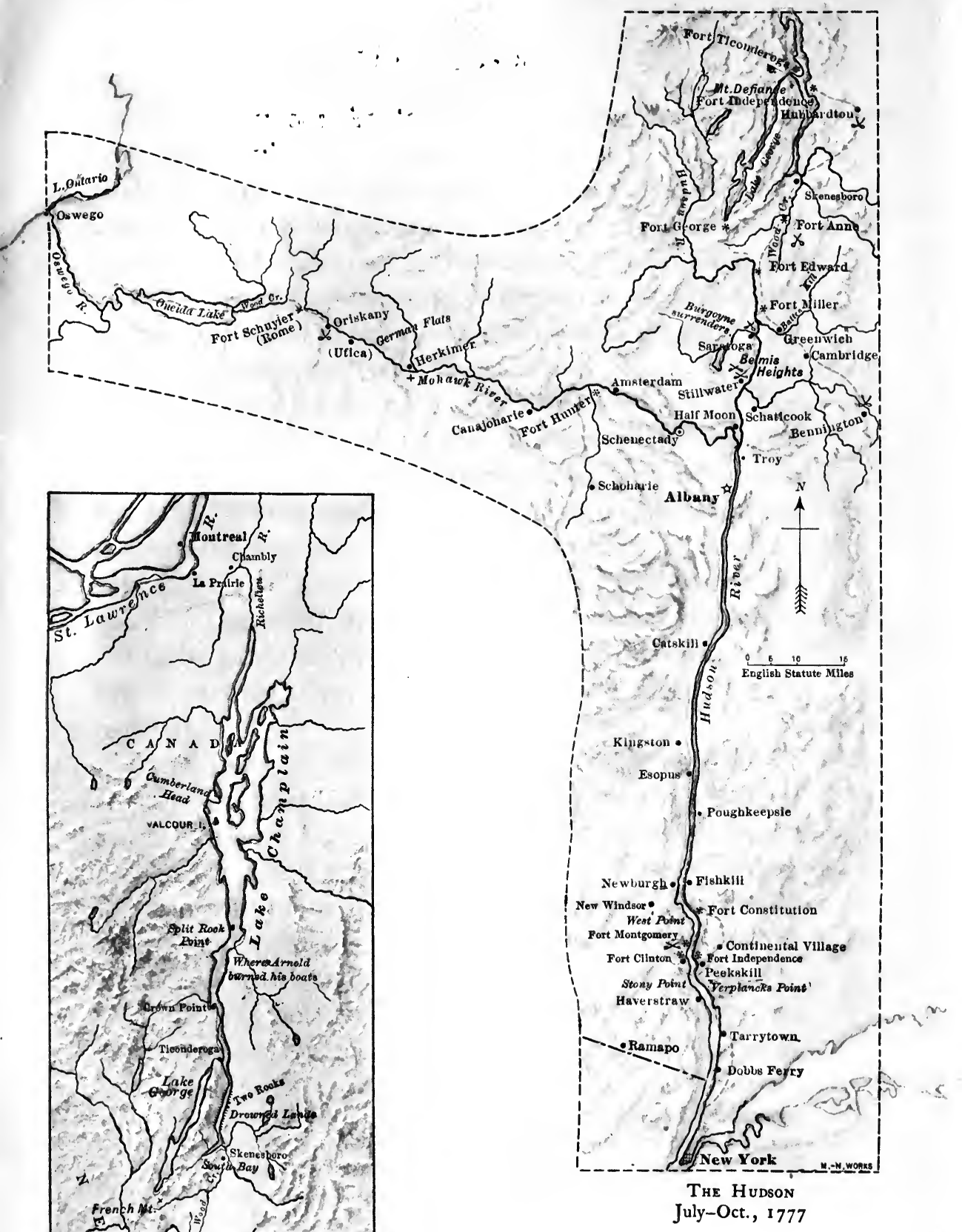

Courtesy of The Burrows Brothers Conpany, Publishers, Cleveland, Ohio From Avery's History of the United States and Its People 
$\therefore:$

$\because \because$ 
up of tories under Sir John Johnson, and detachments 1776 from two regular regiments. ${ }^{1}$

On the American side, the "Northern Department" was still under the command of Schuyler. When Sullivan Situation on the American retreated from Montreal in the summer of 1776, Congress passed a resolution ${ }^{2}$ directing Washington to send Gates to take command of the American forces in Canada. By the time Gates arrived the American forces were no June 17 longer in Canada, but had been driven back to Crown Point and Ticonderoga. Gates interpreted his instructions to give him independent command of the troops in the field, leaving Schuyler the nominal command of the department, but without any real authority. Schuyler submitted the question to Washington, asking the decision of Congress; and Congress decided that Gates was not to be independent of Schuyler. ${ }^{3}$ But their respective and Gates functions were never clearly defined, and much friction resulted.

There were no military movements in the Northern Department after Gates's arrival, except Arnold's brilliant naval battle on Lake Champlain, which, although fought oct.11 by the army, was a naval engagement. When Washing- oct. 13 ton was hard pressed in New Jersey, Gates was ordered, ${ }^{4}$ with seven regiments, to join him; but on his arrival he Dec. 20 pleaded ill health and received leave to go to Philadelphia. He thus was not present at Trenton or Princeton, but spent the next few months in consultation with Congress.

${ }^{1}$ Burgoyne, 12-17; Appendix XI, 51.

In 1780 Burgoyne defended himself before a committee of Parliament, and published a book entitled A State of the Expedition from Canada. It consisted of his narrative, the evidence and an appendix containing the official orders, reports, correspondence and returns.

2 Jour. Cont. Cong., V, 448.

s Ibid., V, 526.

'Sparks, IV, 192, 216, 222. 
1777 That body passed a resolution ${ }^{1}$ desiring him to resume Feb. 20 the duties of adjutant-general, and when Washington heard of this he urged him to accept. ${ }^{2}$ While Gates was March 25 considering the matter Congress passed another resolution $^{3}$ directing him "immediately to repair to Ticonderoga and take command of the army there."

March 15

Congress meanwhile had passed a resolution ${ }^{4}$ severely reprimanding Schuyler on account of a respectful letter which he had written to it concerning matters affecting the discipline of his troops. He determined to proceed to Philadelphia, settle his accounts and retire from the service. The New England delegation had been at all times opposed to him; the New England troops had expressed an unwillingness to serve under him on account of the controversy between New York and New Hampshire over the territory which became the State of Vermont; he had been criticised and held responsible for the failure of the expedition to Quebec; he was denounced as an aristocrat and his loyalty to the United States was questioned. ${ }^{5}$ Twice before he had advised Washington of his intention to resign, ${ }^{6}$ but had yielded to Washington's urgent entreaty to remain in service. ${ }^{7}$ He was now convinced that Congress desired to displace him and that his opportunity for usefulness was gone.

April But on arriving in Philadelphia and presenting his memorial to Congress he was favorably received, was put in command of the troops there in place of Putnam, who had just been ordered to Peekskill, his accounts were speedily settled, and the Board of War made a re-

1 Jour. Cont. Cong., VII, 136.

3 Jour. Cont. Cong., VII, 202.

${ }^{2}$ Sparks, IV, 355.

${ }^{5}$ Sparks, III, 243, 535-540; Irving, 217.

'Ibid., VII, 180.

- Sparks, Letters, I, 109, 287.

'Sparks, III, 191, 209, 243. 
port recommending that he be directed to take command of the Northern Department, and that Gates be offered his choice of resuming the duties of adjutant-general or of serving under Schuyler. ${ }^{1}$ Congress adopted the first part of the report, passed a resolution defining the limits May 22 of the Northern Department (including Ticonderoga), assigning Schuyler to the command of it, and repealing the resolution adopted two years before by which his head-quarters were established at Albany. ${ }^{2}$

Gates did not accept either of the appointments suggested by the Board of War. He was unwilling to serve under Schuyler, and obtained leave to withdraw from June 9 the Northern Department, and proceeded to Philadelphia, July 8 where he continued his intrigues with Congress until that body passed a resolution directing him "to repair to head-quarters and follow the directions of General Wash- april 1 ington." St. Clair, meanwhile, had been selected for April 29 service at Ticonderoga and directed to proceed there forthwith.

After the loss of Ticonderoga (as related hereafter), Schuyler again fell under the ban of Congress, and a resolution was passed directing him to report at head-quarters, aug. 1 and Washington to select another officer to command his department. Simultaneously the New England delegation, headed by John and Samuel Adams, sent a letter to Washington extolling the merits of Gates and asking that he be appointed in Schuyler's place. But Washington wrote to Congress asking to be excused from making the appointment and suggesting that Congress make its own selection. Congress then, "by the vote of eleven aug. 4 States," elected Gates "to command the Northern army." Aug. 19

1 Jour. Cont. Cong., VII, 300, 336, 349, 364.

${ }^{2}$ Ibid., VIII, 375. 
1777 He arrived at the mouth of the Mohawk three days after the victorious battle of Bennington and relieved Schuyler of his command. ${ }^{1}$

These events have been related in detail because they were so scandalous, and had such an important relation to the military operations in the North, to the effort to displace Washington during the following winter, and to the subsequent appointment of Gates to command the Southern army-where his career came to an inglorious end.

Schuyler's Force

May 6

Burgoyne Arrives

May 14

June 20

June 27

Topography at Ticonderoga

The force which Schuyler had at his disposal to oppose the advance of Burgoyne against Ticonderoga and St. Leger against Stanwix was very small. St. Clair, who commanded at Ticonderoga, had $2,546^{2}$ Continentals and 900 militia. Outside of this, there were only small detachments of militia at Skenesborough (now Whitehall), Fort Ann, Fort Edward and Albany.

Burgoyne had arrived at Quebec as soon as the ice was out of the St. Lawrence. Sir Guy Carleton, the Governor of Canada, although practically superseded by Burgoyne, rendered him every assistance. Burgoyne went on to Montreal and there found his troops, an enormous train of siege artillery (in addition to that previously mentioned) and an ample fleet to convey his force across Lake Champlain. ${ }^{1}$ Everything was speedily assembled at Cumberland Point (Plattsburg), and a week later he landed at Crown Point. ${ }^{3}$

Ticonderoga played such an important part in the French and Indian wars, the Revolution and the War of 1812, and will have such an essential part should we ever, unfortunately, be again involved in hostilities with

1 Jour. Cont. Cong., VIII, 540; VII, 217; VIII, 596, 604; Sparks, V. 14.

2 Carrington, 311; Dawson, 231.

${ }^{3}$ Burgoyne, 9-11. 
Great Britain or Canada, that it may be well to describe somewhat in detail the topographical features which create such importance. From Montreal to New York the distance (by rail) is 384 miles; and paralleling the rail and other roads is a navigable water route for the greater part of the distance-149 miles from New York to Troy and 147 miles from Whitehall to St. Johns. Between Troy and Whitehall, the valley of the Hudson is followed for 49 miles to Fort Edward; thence to Whitehall, 22 miles, there are two low valleys (through which the Champlain canal has been constructed), the one leading out of the Hudson and the other into Lake Champlain at Whitehall; and the highest point of the land between them is only 147 feet above sea level.

This long, narrow depression, between the St. Lawrence and Sandy Hook, is flanked (in its northern half) by mountains rising to a height of 2,500 feet or more-the Green Mountains of Vermont on the east and the Adirondacks on the west. It has been a natural highway for the early explorers, for the Indians, for military operations and for commerce; it has rare scenic beauty.

For more than 20 miles at its southern end, Lake Champlain has a width of half a mile or less, and lofty, rugged hills rise on either side from the water's edge. Then, as it widens and comes into a more open country, it passes between two mountains, Mount Independence on the east and Mount Defiance on the west, which overlook the country for a long distance to the north; and at this same point it meets the outlet of Lake George, which discharges its water through a narrow gorge about 3 miles long, in which there is a drop of about 220 feet.

The surrounding hills are now and always have been densely wooded. 
Through this gateway the Colonial militia attempted, without success, to force their way in their first encounter with the French in 1690. The French then built a stone fort on the point at the edge of the lake, just north of Mount Defiance and Mount Independence, which they named Fort Carillon. In 1758 Montcalm and Levis supplemented this by intrenchments of wood and earth, with entanglements of felled timber in front. Against these Abercrombey hurled 15,000 men in a murderous assault, losing nearly 2,000-the bloodiest battle ever fought on this continent prior to the Civil War. In the following year Amherst attacked it in a more rational manner, by siege operations; and the French, being largely outnumbered, blew up the stone fort and abandoned it. The English partially rebuilt the ruin and named it Fort Ticonderoga. They maintained a garrison there until it was taken by Ethan Allen and Benedict Arnold in 1775, as we have seen. It was the starting-point of Montgomery's expedition to Quebec in that year, and the rallying-point of Sullivan's retreat in the following year.

During the winter and spring its works had been somewhat strengthened and new works had been built on Mount Independence. To man them properly a garrison of 10,000 men was required. St. Clair was authorized to call on the neighboring States for militia, and could have raised them if he had had provisions. ${ }^{1}$ But his supplies were insufficient for the men he had; and Burgoyne's advance thus found him with a garrison of barely 3,500 of whom one-third were militia.

St. Clair's Garrison

They were posted partly at Fort Ticonderoga and partly in the trenches and works on the sides and summit of Mount Independence. A bridge had been built across

${ }^{1}$ St. Clair's narrative, 240-250. 


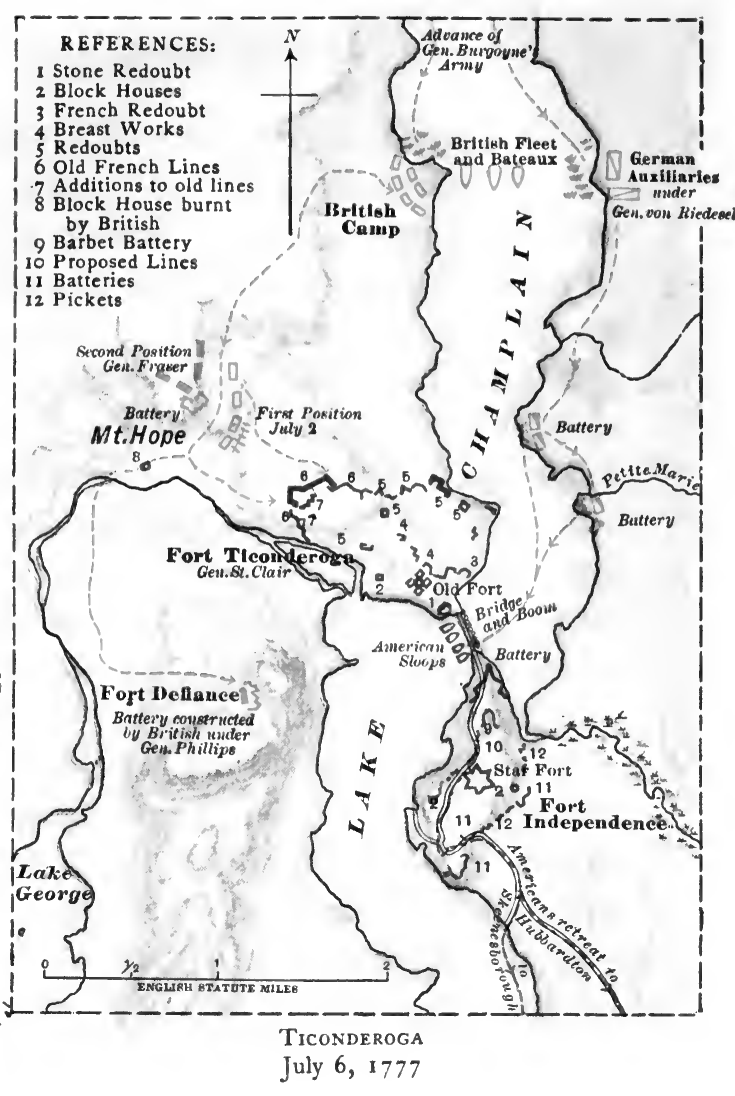

A - Attack of Americans upon British Advance Corps

B - Detachment under Earl of Balcarres

C. American Position after Gen. Riedesel arrived

D - British Position after the action

E. House in which wounded were cared for

$\square=$ American Forces

HUBBARDTOWN

July 7,1777

July 6, 1777

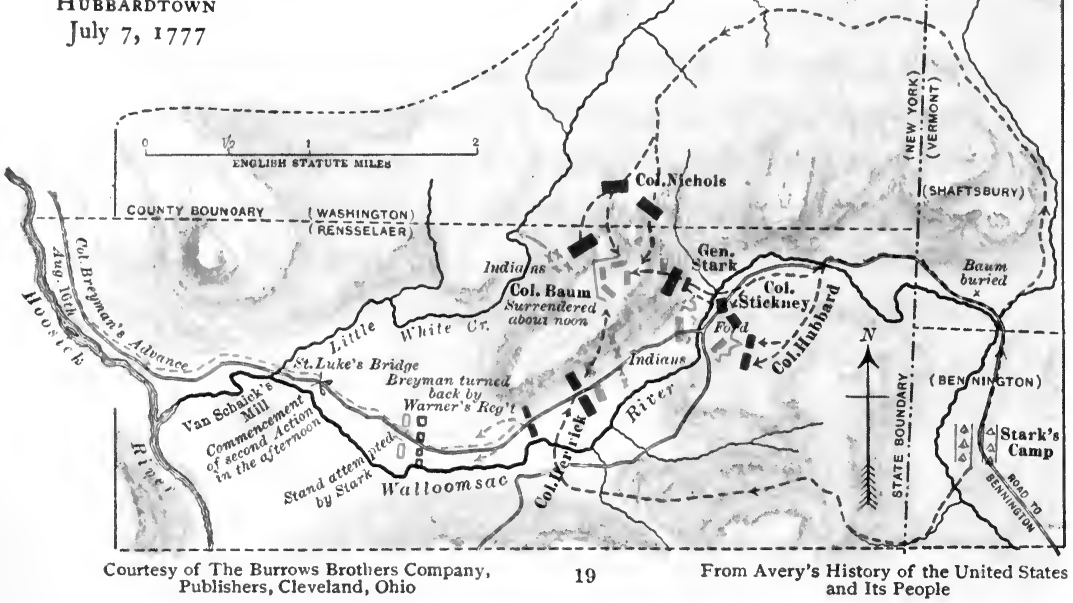

BenNington

Aug. 16, 1777 
$\because i i \because \because+c$

, 
the lake at this point. The commanding hills of Mount

Hope, on the north-west, and Mount Defiance, on the south-west, were not occupied, because the force was insufficient and because Mount Defiance was believed to be inaccessible.

Burgoyne's journal ${ }^{1}$ shows that after remaining three days at Crown Point, to bring up the rear of his army, he advanced in two columns; Fraser's brigade, of about Burgoyne's Advance 3,000 men and 10 guns, on the west side of the lake, and a Hessian detachment on the east; with the main army behind them on both shores and on frigates and gun-boats in the lake. Two days later, Phillips's brigade seized Mount Hope, which commanded the outlet of Lake George, and thus cut off St. Clair from all communication in that direction. ${ }^{2}$ The artillery was then landed July 2 and a reconnoissance was made to the top of Mount Defiance, which was found not to be inaccessible. The British dragged their artillery to its summit, which commanded within easy range the fortifications not only at Ticonderoga but also at Mount Independence. As soon as these guns were discovered St. Clair called a council of war $^{3}$ of his principal officers, and they unanimously July 5 decided that the position was untenable, that Ticonderoga should be evacuated that night, taking the cannon and stores to Mount Independence if possible, and that an immediate retreat should be made from Mount Independence to Skenesborough (Whitehall). The heavy arEvacuation of Ticonderoga tillery-128 pieces-was abandoned; a few lighter pieces with some provisions and stores were placed on boats with Long's regiment and sent up the lake to Skenesborough, while the rest of the force, under St. Clair, un-

${ }^{1}$ Burgoyne, 11, Appendix XXV.

${ }^{2}$ Ibid., XXVII.

${ }^{3}$ Dawson, 231. 
1777 dertook to march to the same point, following a circuitous route of about 45 miles through Hubbardton and Castleton, there being no road through the rough country adjacent to the lake. St. Clair reached CastleJuly 6 ton the next evening, but the rear guard, consisting of Warner's and Francis's regiments, with the stragglers and infirm-about 1,200 men in all-was then about six miles behind, at Hubbardton. ${ }^{1}$ Here they were over-

July 7

Battle of Hubbardton

Engagement at Skenesborough July 6 taken in the morning by Fraser's brigade, which had marched nearly all night. He made a most vigorous attack, and was soon reinforced by the advance guard of the Hessians under Riedesel. ${ }^{2}$ Warner was defeated, Francis was killed, their retreat to Castleton was cut off, and their men dispersed through the mountains to the eastward. ${ }^{3}$ Their losses were never accurately known. Burgoyne claimed that 200 dead were left on the field and 600 wounded:4 Gordon says the total loss was 324, but does not give his authority. He gives the British loss as 20 officers and 183 killed and wounded. ${ }^{5}$

Meanwhile, Burgoyne in person had pursued Long up the lake. As soon as the retreat was discovered the naval vessels had pushed forward and cut a passage through the bridge, and by 3 o'clock in the afternoon, Burgoyne, with two frigates and several gun-boats, carrying three regiments of infantry, arrived in the vicinity of Skenesborough. ${ }^{-}$The Americans were in a stockaded fort; the British regiments landed and climbed the adjacent hills with the intention of getting in rear of the fort and cutting

${ }^{1}$ St. Clair's Report, Dawson, 229.

${ }^{2}$ Burgoyne, Appendix XXX; Riedesel, I, 363.

s St. Clair's Report, Dawson, 229.

' Burgoyne's Report, Dawson, 234; Riedesel, I, 363.

${ }^{5}$ Gordon, II, 484; Riedesel, I, 363; Burgoyne, Appendix XXXIII.

- Burgoyne, Appendix XXX; Riedesel, I, 362. 
off the retreat. But before this could be accomplished 1777 the fort and the boats near by in the river were set on fire, and Long and his men hastily retreated up the valley of Wood Creek to Fort Ann. Here he was overtaken the next morning by the 9th British Regiment, with the two other regiments of Phillips's brigade only a short Engagement at Fort Ann July 7 distance back. Long attacked the 9th Regiment and a sharp engagement took place, but when the two other regiments came up he was forced to retire. After setting fire to Fort Ann he retreated to Fort Edward.

Hearing that Skenesborough was occupied, St. Clair was forced to retreat from Castleton eastward to Rutland, and after a painful and circuitous march of seven days he joined Schuyler at Fort Edward. The remnants of July 12 Warner's men remained in the vicinity of Rutland. ${ }^{1}$

Burgoyne's campaign thus began with a brilliant victory. The loss of Ticonderoga created consternation in Congress and throughout the Colonies. Washington was then in the vicinity of Ramapo, baffled by conflicting reports of Howe's movements, and heard the news by successive reports received from Schuyler at Fort Edward. He immediately bent every energy to reinforce Schuyler. He sent Morgan's Virginia riflemen from his own army, and directed Putnam to send him two brigades (Nixon's and Glover's); he also ordered Arnold to join Reinforcehim; he sent Lincoln to organize and command the New $\begin{gathered}\text { ments for } \\ \text { schuyler }\end{gathered}$ England militia; and he wrote the most urgent letters to the governors of New York and the New England States, telling them how critical the situation was, and calling upon them to use every effort to fill up their Continental regiments and to call out the militia. ${ }^{2}$ As a

${ }^{1}$ St. Clair's Report, Dawson, 230.

${ }^{2}$ Sparks, IV, 476, 480, 484, 500; V, 17. 
1777 result of these measures, reinforcements kept arriving on the upper Hudson during July, August and September, until at the time of Burgoyne's capitulation Gates's morning return showed 13 brigades of infantry besides artillery and cavalry, with a total strength of 1,698 officers and 18,624 men, of whom 14,914 were present for duty. ${ }^{1}$

The other part of Burgoyne's plan-the expedition under St. Leger from Oswego-met with complete dis-

St. Leger Expedition

April

May 28

July 15

Aug. 4

Aug. 3 aster. The route via Oswego and Oneida Rivers, Oneida Lake, Wood Creek and the Mohawk Valley had also been followed in the earlier French and Indian wars; and a stockaded fort had been built at the portage between Wood Creek and Mohawk River, near the present city of Rome, and called Fort Stanwix. ${ }^{2}$ It was more or less in ruins in the spring of 1777, and Schuyler sent Colonel Gansevoort of the $3 \mathrm{~d}$ New York Regiment to take command. He put the works in as good a condition as possible, and renamed the place Fort Schuyler. He was soon joined by Lieutenant-Colonel Willett and the rest of his regiment. ${ }^{3}$

St. Leger arrived at Oswego and began organizing his expedition. News of this reached General Herkimer, who commanded the militia in Tryon County, and he issued a call for every able-bodied man in the county. They assembled, to the number of about 800, at Fort Dayton, now the village of Herkimer." Thence they marched to the relief of Fort Schuyler, 30 miles to the westward, before which St. Leger had appeared on the previous day. News of their approach reached St. Leger,

${ }^{1}$ Printed in Burgoyne's narrative, Appendix CIV.

Arnold, 141.

${ }^{3}$ Ibid., 149.

- Arnold, 149; Burgoyne, Appendix LXXVIII. 
and he sent all his Indians, under Brant, and a part of his

loyalist militia to ambuscade Herkimer near Oriskany, about 5 miles east of Fort Schuyler. Here the road, on which Herkimer was advancing, crossed a deep ravine, at the bottom of which was a marsh and causeway: Just as Herkimer's force had passed over the causeway aug. 6 and was climbing the western slope of the ravine, ${ }^{1}$ with their wagons still on the causeway, the Indians surrounded them and attacked with great fury. Herkimer Battle of was wounded almost at the first fire, but he caused himself to be propped up against a tree, lighted his pipe and directed the battle for eight hours. ${ }^{2}$ It was a bushwhack- 6 A. м. to ing fight at close quarters, and the Tryon County militia 2 P. M. were as expert in that kind of fighting as the Indians themselves; moreover, they personally knew the tory militia opposed to them, and fiercely hated them. ${ }^{3}$ No quarter was asked or given, and the losses were out of all proportion to the numbers engaged.

During the morning three messengers from Herkimer, 11 м. м. sent to advise the garrison of his approach, succeeded in reaching Fort Schuyler. Lieutenant-Colonel Willett, with 250 men, was immediately ordered to make a sortie, which was completely successful, the tory and Indian camps being both captured, with a large amount of supplies and all of St. Leger's and Johnson's papers. The Indians fled to the woods. When news of this reached the ambuscading party an hour or so later, the Indians there also fled, leaving Herkimer and his militia in possession of the field. ${ }^{4}$

${ }^{1}$ The spot is marked by a large monument just south of the New York Central tracks, 225 miles from New York City.

Arnold, 151; Lossing, I, 246.

3 Dawson, 242.

- Arnold, 15:. 
Siege of Fort Schuyler

Aug. 12

Aug. 21

Aug. 22

Defeat of St. Leger

Notwithstanding this success, the siege was not yet abandoned. Herkimer was carried back to his home and died of his wounds. About one-third of his militia had been killed and wounded, and the rest soon retired to Fort Dayton (Herkimer). St. Leger gathered together his tories and Indians and his 200 regulars, and closely invested Gansevoort in Fort Schuyler. Willett was then sent to ask aid from Schuyler. With one companion he succeeded in making his way through St. Leger's line and reached Schuyler, then at Stillwater. Schuyler called the usual council of war and explained the importance of relieving Fort Schuyler. To his astonishment there were mutterings accusing him of cowardice and treason, and intimating that he was planning this move in order to give Burgoyne an opportunity to enter Albany unopposed. Schuyler then called for a brigadier to lead the relieving party, and Arnold, although a major-general and second in command, instantly volunteered.

With 800 men, all of whom had volunteered for the service, he began his march the following day, and soon reached Fort Dayton. From this point he contrived to send men into St. Leger's camp carrying exaggerated statements of his strength, and was preparing to follow them and attack St. Leger, when the Indians, alarmed at these reports and discouraged by the losses at Oriskany and the sortie, became mutinous and deserted in a body. The next day St. Leger raised the siege, and with his regulars and the few tories who still remained with him, retreated hastily to Oswego, and later to Montreal. ${ }^{2}$

Thus ended St. Leger's expedition.

While these events were in progress others of equal importance to the success of the Americans were trans-

${ }^{2}$ Arnold, 153-162; Dawson, 247; Lossing, I, 243-252. 
piring near the upper Hudson. After the battle of

Hubbardton and the engagements at. Skenesborough and July 7 Fort Ann, Burgoyne assembled his entire force at Skenes- July 6 borough and prepared to advance to the Hudson at Fort July 8 Edward. ${ }^{1}$ He decided to use all his boats to bring his supplies via Lake George, but to march his men by the direct route through the wilderness of Wood Creek. Although the distance was only 22 miles, a road had to be cut for nearly the entire distance, and the obstructions which Schuyler's axemen had created had to be removed. Thus 20 days were consumed in the operation. At the end of that time Burgoyne arrived at Fort Edward, and on the same day Phillips took possession of Fort George, July 29 at the head of Lake George. Fort George then became Burgoyne's secondary base of supplies, but although the distance to Fort Edward was only 15 miles, the country Burgoyne Takes Fort was so broken and heavily wooded, and the transportation so poor, that it was with great difficulty that his army could be supplied. ${ }^{2}$

Schuyler's reinforcements had hardly yet begun to arrive, and his force was too small to oppose any resistance to Burgoyne. He therefore abandoned Fort Edward and Schuyler Retreats to Stillwater retreated down the west bank of the Hudson to Still- July 31 water, about 25 miles south of Fort Edward and the same distance north of Albany. ${ }^{3}$

The fatal defect of Burgoyne's plan was the inability to supply his army. At Fort Edward he was 185 miles from his base at Montreal. There were 23 miles of land Difficulty of Supplying Burgoyne's transport at the northern end and 15 miles at the southern end, and the latter was through most difficult country. The intervening 147 miles was by water, Lakes ChamArmy

${ }^{1}$ Burgoyne, Appendix XXXIV.

${ }^{2}$ Ibid., 16-19.

${ }^{3}$ Arnold, 140-148. 
plain and George, but there was a troublesome portage between the two at Ticonderoga.

Burgoyne, therefore, began to look for supplies in the enemy's country. He had heard that Bennington-in the southern part of the "Hampshire Grants," now the State of Vermont, but then claimed both by New York and New Hampshire-was a great depot of corn, flour and cattle; that it was defended by only a few militia; and that the district "abounds in the most active and most rebellious race of the continent, and hangs like a gathering storm on my left." " He therefore determined to deliver a blow at Bennington, capture its stores, disperse its militia, and strike terror to its inhabitants. Incidentally he expected to obtain horses to mount the Duke of Brunswick's Dragoons, a project which Riedesel had much at heart. If the move succeeded, he thought it would prevent the sending of any American reinforcements to the relief of Fort Schuyler, and would enable St. Leger to join him in a triumphant entry into Albany. ${ }^{2}$

For this expedition Burgoyne detailed the Brunswick dragoons (unmounted), Captain Fraser's selected marksmen, some tory militia and some Indians, and 2 field guns, the whole numbering about 600 men under command of Lieutenant-Colonel Baume. ${ }^{3}$ To facilitate the

Raid toward Bennington Aug. 14 operation and to be ready to take advantage of its success, Burgoyne moved down the east side of the Hudson and built a bridge near Saratoga (now Schuylerville). ${ }^{3}$ Schuyler fell back to the islands at the mouth of the Mohawk. ${ }^{4}$

Baume left the Hudson at Saratoga, and moving up the Battenkill crossed the hills to Cambridge and thence

${ }^{1}$ Burgoyne, Appendix XLVI; Riedesel, I, 368-372.

Burgoyne, XLIV.

3 Ibid., XI.I.

- Arnold, 163-165. 
to the Hoosick River at the mouth of Walloomsac

Creek. There he encountered a small party of American militia, and he soon learned that Burgoyne had based Aug. 14 his plans upon quite erroneous information.' There was, in fact, a body of New England militia, under General John Stark, far exceeding his own force in numbers, posted at the village of Bennington, about 7 miles up the Walloomsac, ${ }^{2}$ and the remnants of the regiments which had fought under Warner at Hubbardton seven weeks before were now resting and recruiting at Manchester, about 20 miles to the north. Baume sent a messenger to Burgoyne with a report of these facts. ${ }^{3}$

Stark had served in the French and Indian wars, had taken a New Hampshire regiment to Boston in time for Bunker Hill, had been colonel of the 5th Continental Regiment in the following year, and had served in all the engagements under Washington, including Trenton and Princeton. Then several promotions were made over his head at which he took offence, resigned and retired to his farm. When Ticonderoga fell, the New Hampshire legislature made him a brigadier-general and asked him to raise the militia for their defence. They had no confidence in the officers who commanded under Schuyler, and when Lincoln, sent by Washington to organize the New England militia, ordered Stark to join Schuyler at Stillwater, Stark refused point-blank, and said it was at his own option whether he acted in conjunction with the Aug. 14 4 A. $M$.

Continental army or not. ${ }^{4}$ When Congress heard of this it sent the correspondence to the New Hampshire legislature, with a resolution saying that Stark's action was

Stark Refuses to Obey Orders

Congress Censures Him

1 Baume's Report; Burgoyne, Appendix LXX.

${ }^{2}$ Stark's Report, Dawson, 260.

${ }^{3}$ Burgoyne, LXX.

'Stark's Memoirs, 10-50. 
1777 "destructive of military subordination," and requesting Aug. 19

And Then Gives Him a Vote of Thanks Oct. 4

Aug. 14

Burgoyne Sends Reinforcements to Baume

Aug. 15 that he be instructed to conform to the "same rules which other general officers of the militia are subject to whenever they are called out at the expense of the United States." This was three days after Stark had gained the victory at Bennington. On hearing of this Congress expressed its appreciation of what Stark had done, and later passed a resolution giving him a vote of thanks and appointing him a brigadier-general in the Continental army. ${ }^{1}$

Seldom has such rank insubordination produced such excellent results. In this case it resulted in placing Stark, with superior force, at the very point where Baume was going to collect stores and horses; as the latter approached Stark sent word to Warner to march at once to his relief, and in spite of a drenching rain Warner arrived in time to be of assistance.

Burgoyne received Baume's report during the night, and immediately ordered Lieutenant-Colonel Breyman, with the Brunswick grenadiers and other Hessians, 642 men in all, with 2 field guns, to reinforce Baume; and marching as rapidly as he could over the bad roads in the heavy rain, Breyman arrived while the battle was in progress. $^{2}$

After spending a day at Van Schaick's mill, Baume moved forward the next morning, the advance guard of the militia retreating before him. But after he had moved up the north bank of the Walloomsac about four miles, the militia were reinforced by Stark's main body, coming down the creek from Bennington. Baume hesitated to attack, and selecting a good position, spent the

1 Jour. Cont. Cong., VIII, 656; IX, 770.

${ }^{2}$ Burgoyne, XLIII; Riedesel, 127-133. 
rest of the day in intrenching. His unmounted dragoons were loaded down with immense hats, boots, swords and muskets; and on a hot August day in a thinly settled country, with bad roads and torrents of rain, were ill equipped to match the New Hampshire farmers in their shirt-sleeves and with no impedimenta except a gun and cartridge-box. ${ }^{1}$

Early the next morning Stark sent out these farmers, Aug. 16 whom Baume at first did not recognize as soldiers, to surround the Hessians; 200 under Colonel Nicholls by the right, 200 under Colonel Herrick by the left; while the main body, under Stark himself, moved down the creek to attack them in front. Before Baume realized it he Battle of Bennington was surrounded by double his numbers-all good marksmen. His Indians fled at the first shot, but the Brunswickers fought hard and used their two little field-guns to the best advantage. Two hours of incessant fighting followed, which finally became a hand-to-hand encounter after the ammunition was exhausted. Baume was mortally wounded, a large part of his force had been destroyed, some surrendered, and the rest escaped down the creek.

Stark's men divided their attention, some plundering $12 \mathrm{м}$. the Hessian camp and some pursuing the retreating dragoons. When the pursuit had gone about half-way to Van Schaick's mill, Breyman arrived from one direction and Warner from the other; the battle was fiercely renewed and Breyman lost almost as heavily as Baume had. Abandoning his artillery ${ }^{2}$ and wagons at dusk, he hastily retreated to the Battenkill and Saratoga.

${ }^{1}$ Stark, 50-75; Lossing, I, 391, 399.

2 The history of these four guns is interesting. They were of French manufacture, were taken by Wolfe at Quebec in 1759, captured by Stark at Bennington in 1777, surrendered by Hull at Detroit in 1812, retaken at Niagara in 1813. Fonblanque's Burgoyne, 273. 
Burgoyne's Precarious Position

July 29 to Aug. 20

Sept. 13

Burgoyne Advances

Stark's force, including Warner's men, numbered about 2,000; Baume and Breyman had about 1,300. The American losses, according to Stark's report, were only 30 killed and 40 wounded; he also reported that there were 207 Hessians dead, a large number wounded and that he had taken 700 prisoners. The Hessian accounts put the number at somewhat less; but even these admit the loss of 596 men, exclusive of the loss among the British. ${ }^{1}$ Thus the Hessian detachment on the east and St. Leger's expedition on the west were practically destroyed, almost at the same time. Burgoyne's position immediately became precarious. It was just at this time that Gates arrived and superseded Schuyler. The army was immensely elated by the two victories, the militia turned out in large numbers, Stark soon marched to join Gates, and the reinforcements of Continental troops were now coming in rapidly from New England and from Peekskill.

Burgoyne had now been on the Hudson for three weeks, slowly and with infinite toil dragging his provisions and boats over from Lake George in the hope of accumulating a sufficient supply to last him during an offensive campaign of thirty days, and enough boats to move them on the Hudson, from one rapids to the next, as he advanced toward Albany. He continued this work for three weeks longer, and then believing that he had sufficient supplies, he crossed from the east to the west bank of the Hudson on the bridge which he had built just above the mouth of the Battenkill, and moved forward. His letters to Germain show that he was far from being confident of success. He said: "I yet do not despond." "

${ }^{3}$ Burgoyne, XLIII; Riedesel, 132; Dawson, 259.

${ }^{2}$ Burgoyne, XLVIII. 
Nevertheless he knew he was already outnumbered by 1777 the reinforcements which had come to the American army; he realized that he was far from his base of supplies, that he could not obtain supplies from the enemy's country and that his communications were in danger of being cut off. He could probably have saved his army by a prompt retreat to Ticonderoga. To have done so would have been to acknowledge the failure of the whole plan which he had induced the King to adopt. Moreover, he had a lingering, though faint, hope that Howe would march up the Hudson; and finally the King's orders of March 16 required him "to force his way to Albany." As he wrote Germain, he felt that he was not aug. 20 at liberty to disregard these.

Gates, on his arrival, found the main body of the aug. 19 American army on the islands at the mouth of the Mohawk, with Poor's brigade 4 miles up the Mohawk on his Army left, Lincoln and Stark at Bennington, 30 miles on his right, and Arnold on the upper Mohawk, 110 miles on his left. Arnold, after the relief of Fort Schuyler, promptly returned and joined Gates just as Burgoyne was preparing to cross the Hudson. Gates had already sept. 10 issued orders to have everything in readiness to march, but had made no movement. When Arnold arrived and was assigned to the command of the left wing, he took Kosciusko (apparently on his own responsibility), made sept. 12

a reconnoissance of the ground in his front, selected a position at Bemis' Heights, about 6 miles in advance, and furnished Kosciusko the men to fortify it. ${ }^{1}$ The lines were on a plateau about 200 feet above the Hudson, with a deep ravine (Mill Creek) in their front, and extended around three sides of a rectangle more than 2

${ }^{1}$ Arnold, 165-178. 
Battle of Freeman's Farm

1 P. M. to 2 P. M.

3 P. M.

miles in length. Gates's army, about 9,000 strong, occupied these lines, Arnold on the left and Gates on the right, when Burgoyne, after five days of cautious advance, came in sight. The latter's plan was to send Fraser and Breyman on his right to move around the head of the ravine and attack the American left; he himself with the main body of the British was to cross the ravine, and, deploying on the southern side of it, to attack the centre; while Phillips and Riedesel were to move along two roads near the Hudson and protect his left. His force had been reduced by losses to a strength of about 6,000 men. As his columns on the march were widely separated in a broken country, their arrival in position was to be announced by the firing of signal-guns, and these were heard early in the afternoon.

These movements had been observed for more than three hours, but Gates gave no orders. Arnold at length, after much entreaty, obtained permission to send Morgan's riflemen against the Canadians and Indians who formed Fraser's advance. Morgan attacked with such impetuosity that his men got out of hand, and when, after driving back the Indians and Canadians, he came upon Fraser's main body, he was in turn driven back with considerable loss. Seeing this, Arnold, without waiting for further orders, brought up his entire force, and leading them in person he made a furious assault upon Fraser. The fighting continued at close quarters and often hand to hand for about four hours. Arnold applied for reinforcements to Gates, but Gates refused to send them for fear that he would expose his camp. Phillips and Riedesel, finding that Gates did not advance against them, marched to the sound of the guns and Arnold had nearly the whole of Burgoyne's force opposed to him. Not- 


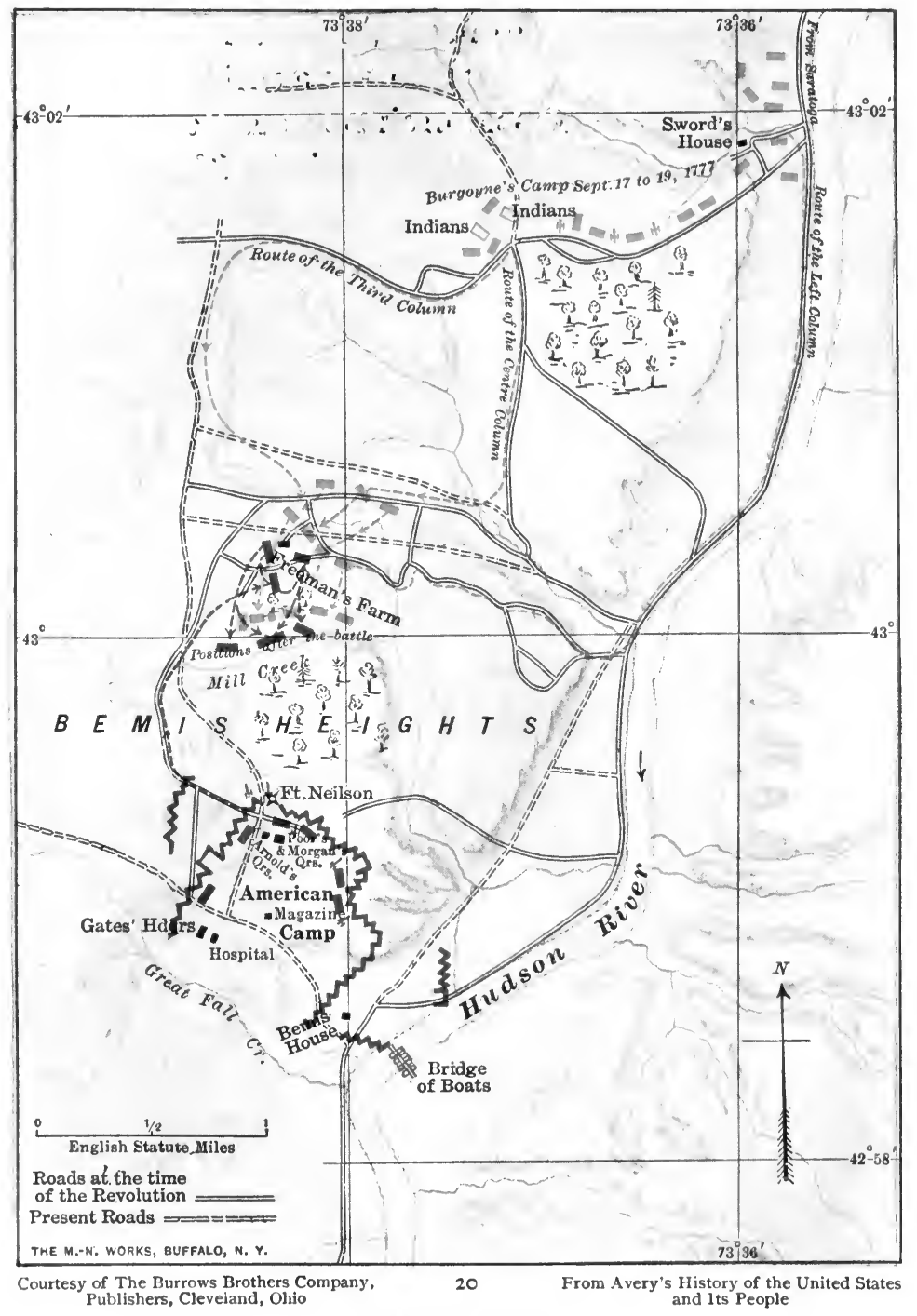

FreEMAN'S FARM

Sept. I9, I 777 


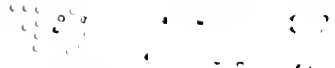

$$
\begin{aligned}
& \therefore \vdots \vdots \because \cdots: \div \because \div \therefore \text { : }
\end{aligned}
$$


withstanding the superiority of the force opposed to him, 1777 he held his ground until sunset, and then returned within his lines. The British lay upon their arms, where they were when the fighting terminated.

The losses on the American side were 65 killed, 218 wounded and 33 missing; on the British side more than Report of Wilkinson, 500. One regiment, the $62 \mathrm{~d}$, which left Canada 500 Adjutant-General, Sept. 22 strong, came out of this battle, according to Burgoyne, with only 60 men and 5 officers. ${ }^{1}$

This was the first of the Saratoga battles, sometimes called Freeman's Farm and sometimes Bemis' Heights. Instead of attacking, as he had intended, Burgoyne had been thrown on the defensive from the beginning of the action. The next day he began intrenching on the north and east sides of the Mill Creek ravine, about a mile or more distant from the American lines; and he remained there until the second battle, eighteen days later. The Americans, meanwhile, continued to strengthen their lines.

On the second day after the battle, Burgoyne received sept. 21 word from Sir Henry Clinton advising him of his intention to attack Fort Montgomery, opposite Peekskill; ${ }^{2}$ and Burgoyne sent back the same messenger that night, and followed this by two other messengers. They all carried the same message, viz., that Burgoyne could hold out until October 12, and he urged Clinton to come to his assistance before that date. All three reached Clinton oct. 8 in safety, and the latter sent them all back. The return oct. 9 trip was not so successful. The bearer of one message, Sergeant Taylor, was captured at Kingston and hung as a spy; Captain Campbell, who carried the second, is

${ }^{1}$ Dawson, 285-290; Riedesel, 144-150; Arnold, 170-190.

${ }^{2}$ Burgoyne, 24. 
1777 said by Lossing to have delivered it to Burgoyne on the oct. 17 night before the surrender, although Riedesel does not mention this; Captain Scott, who bore the third, was unable to reach Burgoyne, and after the capitulation escaped down the river and joined the British fleet.

oct. 8 The message which was intercepted was written at Fort Montgomery, and was in these words: "Nous y voici, and nothing now between us and Gates. I sincerely hope this little success of ours may facilitate your operations. In answer to your letter of 28 th of September by C. C. [Captain Campbell] I shall only say, I cannot presume to order, or even advise, for reasons obvious. I heartily wish you success." 1

This indifferent reply, sent to a brother general who had just informed him how desperate his situation was, shows that Clinton's point of view in regard to the Hudson campaign was very different from Burgoyne's.

On the American side, Gates now became intensely jealous of Arnold. He did not mention his name in the sept. 22 report which he made to Congress (not to Washington) of the battle; and his adjutant-general, Wilkinson, was circulating reports that Arnold had not been on the field. The feud was stimulated by the fact that Schuyler's staff officers had remained with the army and were serving with Arnold. Finally Arnold, whose mind was illbalanced, although he was a brave and skilful soldier, became so incensed that, after a stormy interview with Gates, he foolishly applied for permission to leave the army, which Gates promptly gave him. But Arnold was very popular with his troops, and they begged him to remain. Arnold decided to do so, but Gates then refused to allow him to resume command, and announced

${ }^{1}$ Sparks, V, 131; Lossing, I, 684. 
his intention to assign Lincoln, as soon as he should

arrive, to command his division. When the second battle came on Arnold was in camp without any defined position. ${ }^{1}$

Meanwhile, Lincoln was collecting the militia near Bennington, but before marching to join Gates he sent a detachment under Colonel Brown on a raid against sept. 18 Burgoyne's communications. Brown marched via Hubbardton to Mount Independence and captured that hill, while part of his force went by way of Skenesborough to American Raid on Burgoyne's Communications Mount Defiance. Brown took 293 prisoners, released 100 Americans and captured all the outlying posts, but was unable to take the fort at Ticonderoga. He then rejoined Lincoln, and the latter brought his troops, about sept. 27 2,000 in number, to Gates's camp. ${ }^{2}$ Gates now outnumbered Burgoyne more than two to one, but he made no move against him; and Burgoyne remained on the defensive, hoping from day to day to hear of Clinton.

No news came. ${ }^{3}$ Clinton, however, was moving up the Hudson. His expedition was undertaken under the following circumstances. Although Germain had failed to give Howe any instructions to co-operate with Burgoyne, ${ }^{4}$ yet the latter had written to Howe three letters-from Plymouth in April, from Montreal in May and from Crown Point in June ${ }^{5}$-in each of which he had advised Howe of the instructions he had received to force his way to Albany and effect a junction with him. Howe received all three letters at New York; and just before sailing for the Delaware, he sent Burgoyne a brief and indefinite reply saying that "after your arrival at Albany, the movements of the enemy will guide yours; . . . Sir

1 Arnold, 190-195.

1 See page 78, ante.
2 Lossing, 150.

s Burgoyne, 9, 11.
3 Burgoyne, 25. 
1777 Henry Clinton remains in the command here, and will act as occurrences may direct." But after arriving in the Delaware and before sailing to the Chesapeake, Howe July 30 decided to write to Clinton, suggesting that he make a diversion in Burgoyne's favor, if he could do so without endangering the security of Kingsbridge. The date when Clinton received this letter is not known. It was prior to September 12, the day on which he wrote Burgoyne of his intention to attack Fort Montgomery. But Clinton did not move until the long-delayed reinforce-

Oct. 3

Clinton Moves up the Hudson

Oct. 5

American Force in the Highlands

Oct. 5 ments arrived from England, nearly three weeks later.

Then he started up the Hudson with three columns, one of which marched from Kingsbridge to Tarrytown and the other two proceeded to the same point by water. The total force was about 3,000 men, and it was convoyed by several ships of war. At Tarrytown the entire force was put on boats and landed again at Verplanck's Point, threatening Putnam at Péekskill. ${ }^{1}$

Putnam had about 1,200 Continentals and as many militia. They garrisoned the forts, which had been built at great expense early in the year, at the southern entrance to the Highlands; Fort Independence on the east side and Forts Montgomery and Clinton on the west. The river was obstructed by a boom and chain opposite Fort Montgomery, and two frigates were on the north side of the boom to protect it. When Putnam saw this strong force approaching the eastern shore he retired to the hills behind Peekskill, and brought over a part of the force stationed on the west shore. A few hours later the British galleys had advanced far enough up the river to prevent any further communication between the two shores, so that Putnam, when he desired on the following

${ }^{1}$ Clinton's Report, Dawson, 344. 
day to send men to the relief of the forts on the west shore, 1777 was unable to do so. ${ }^{1}$ In reality Clinton's move at Verplanck's Point was only a feint; his real objective was the west shore. He seems to have been well posted in regard to these forts, and his dispositions were skilfully made. At daybreak the next morning his entire force oct. 6 landed above Stony Point, and was pushed forward through the deep valley behind the Dunderberg until it came within about a mile of Fort Clinton. Here the advance, consisting of the $52 \mathrm{~d}$ and 27 th Regiments and some tory militia, about 900 in all, under Colonel Campbell, marched around Bear Hill into the valley of Peploap's Kill, ${ }^{2}$ which empties into the Hudson between the two forts, to attack Fort Montgomery. The main Capture of Forts Montgomery and body, about 1,100 men under General Vaughan, which Clinton accompanied in person, was to attack Fort Clinton from the south. The rest of his force, under General Tryon, was in reserve, keeping up communication with the fleet, and ready to support either column if necessary. ${ }^{3}$

The two forts were under command of General James Clinton. His brother, General George Clinton, ${ }^{4}$ recently elected Governor of New York, was attending a session of the legislature at Kingston. Hearing that a movement up the river was projected, he adjourned the legislature and hastened to his brother's assistance, bringing with him such militia as he could gather, which carried the total strength of the garrison to about 800 men. He arrived two days before the British landed. On

1 Putnam's Report, Dawson, 341.

2 So named on the map in Stedman, vol. I; now called Popelopen Creek.

' Clinton's Report, Dawson, 345.

- Fort Clinton was defended by James Clinton and George Clinton, and captured by Sir Henry Clinton. 
1777 Sunday evening he sent out a reconnoissance to the Oct. 5 south and it returned the next morning with the information that the British had landed. Governor Clinton despatched as many men as he could spare to scour the roads to the south. They soon met the British and were driven back. The British attack was then made by both columns, and though it encountered a spirited defence, the assailants entered both works about sunset. Part of the garrisons surrendered and the rest escaped over the hills and across the river. The British loss was about 40 killed and 150 wounded; that of the Americans about 250 killed, wounded and missing. The two American frigates were burned by their crews, who escaped to the east shore. The boom and chain across the river were destroyed. The British ships sailed up the river and attacked Fort Constitution, opposite West Point, and it was hastily abandoned. Putnam, with the men who had been at Peekskill, retreated up the river to Fishkill. The Americans lost 67 cannon in the various forts and 30 on the frigates, besides a large amount of powder, ordnance stores and provisions. ${ }^{1}$

It was a signal success on Sir Henry Clinton's part, and, as he wrote to Burgoyne, there was nothing between him and Gates. If he had pushed on quickly to Albany he might have changed the whole situation. But instead

1777 of doing so he wrote to Burgoyne a trifling letter, ${ }^{2}$ sent Oct. 8 Vaughan up the river on a marauding expedition as far as Kingston, which was burned, and then returned with his entire force to New York. He attempted to justify his action on the ground that he could not take any

${ }^{1}$ Reports of Governor Clinton, Sir Henry Clinton and Putnam, Dawson, 341-346; Sparks, V, 88, 91, 471-476.

${ }^{3}$ P. 118, ante. 


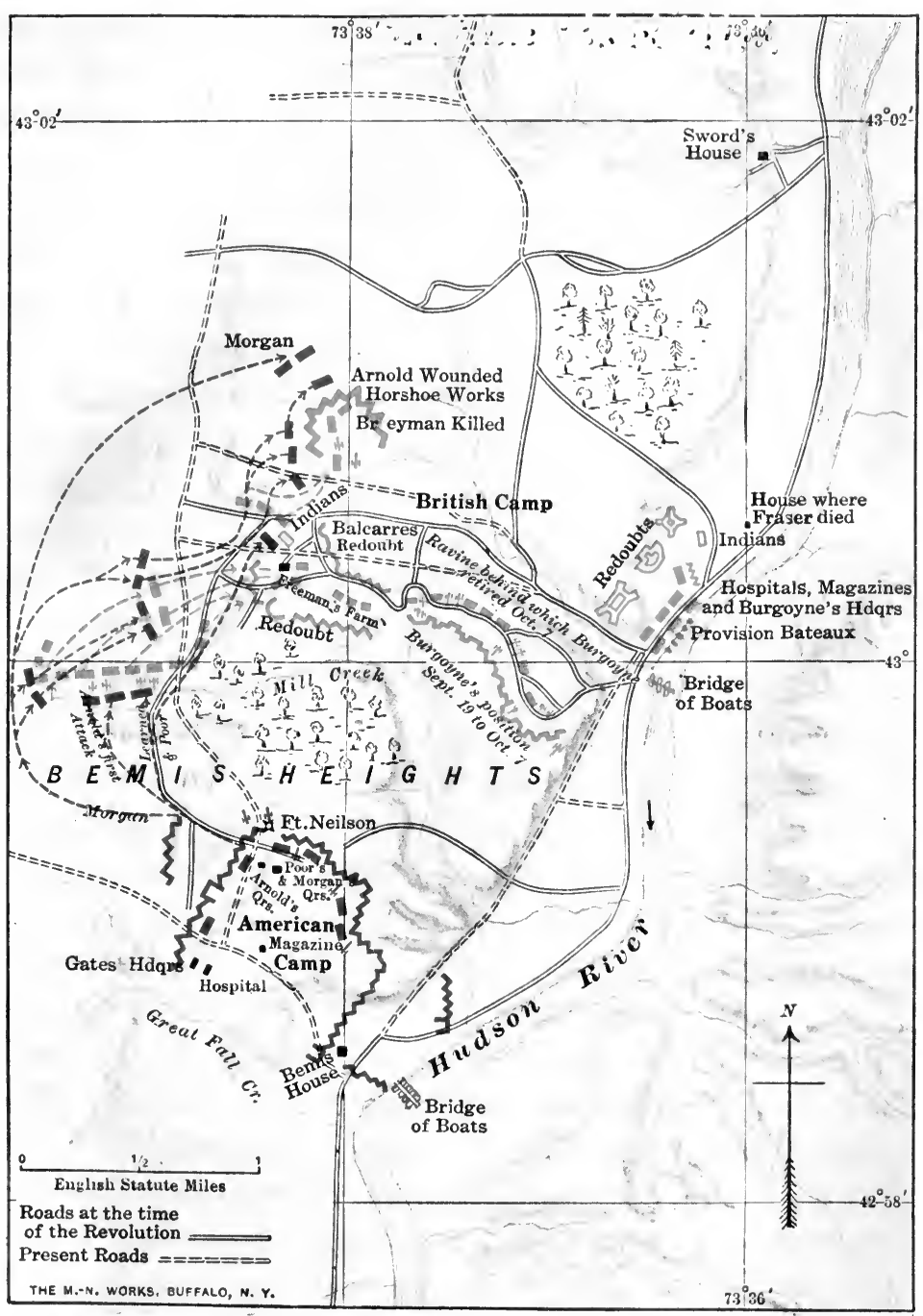

Courtesy of The Burrows Brothers Company, Publishers, Cleveland, Ohio

2 I

From Avery's History of the United States Bemis Heights

Oct. 7,1777 


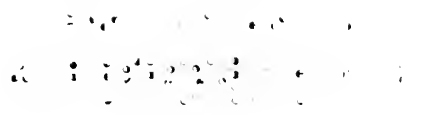


chances at New York. The excuse was not sufficient, for he had 8,500 men, and there was no enemy nearer than Putnam, whom he had driven away from Peekskill, and Washington, who was in front of Philadelphia confronted by a superior force under Howe. Clinton acknowledges that he understood from Captains Campbell and Scott how desperate Burgoyne's situation was. That under these circumstances he was so concerned about the safety of New York can only be explained on the theory that Washington's wonderful exploit at Trenton and Princeton in the preceding winter had made Clinton attribute to Washington almost supernatural powers.

Burgoyne's situation was indeed desperate. He had written to Clinton that he could hold out until the 12th. On the $3 \mathrm{~d}$ he put his men on half rations, and on the $7 \mathrm{th}$, still hearing nothing from Clinton, he determined to attack; but his advance was made in a half-hearted fashion, for the purpose, as he said in his report to Germain, of discovering "whether there were any possible means of forcing a passage, should it be necessary to advance, or dislodging him, for the convenience of a retreat." 1 Having started the battle, he lost control of it, and Arnold fell upon him with fury, inflicting a terrible defeat.

Leaving the greater part of his force in the intrenchments which he had constructed on the north and east Burgoyne's Desperate Situation, Oct. sides of Mill Creek, Burgoyne in person took 1,500 regulars oct. 7 and six pieces of artillery, and attempted to go around the $11 \mathrm{\Lambda .} \mathrm{m}$. head of Mill Creek ravine and attack the American left. His movement was detected, and before he reached the American lines Gates had sent Morgan's riflemen to attack his right, and a strong force consisting of Poor's brigade, two New York regiments and the Connecticut militia to

${ }^{1}$ Burgoyne, LXXXIX. 
assail his left. Severe fighting was the immediate result; Fraser was mortally wounded, and Burgoyne, abandoning his artillery, was driven back across the ravine and into his lines. Arnold, although deprived of all command, had gone into the fight with his troops, leading them and inspiring them. Finally he took entire charge, brought up all the troops he had lately commanded and, himself in the van, hurled them against the lines held by Earl Balcarras in the centre, and later against a strong redoubt held by Breyman on the extreme right of the British lines. The fighting continued throughout the autumn afternoon. Balcarras made a successful defence; but Breyman was killed, a large part of his men were taken and his works captured just before sunset. Arnold was wounded as he entered the redoubt.

Night put an end to the fighting, which had resulted in a loss on the American side of only 150 men, whereas the British had lost about 600.' There was no question of Burgoyne's defeat, and during the night he abandoned his lines and part of his tents and provisions, retreated about a mile across a creek to the north of Mill Creek and took refuge in three redoubts overlooking the Hudson which he had previously constructed. ${ }^{1}$ Gates did not appear on the field, but remained in his tent, spending a good part of the day in discussing the merits of the Revolution with Burgoyne's aide who had been wounded and captured.

Oct. 8 The next day there was skirmishing in front of these redoubts, while three columns in succession were sent past his right flank to capture the fords of the Hudson in his rear. Detecting these movements during the after9 P. s. noon, he abandoned his hospital and wounded and re-

${ }^{1}$ Burgoyne, XC-XCII; Arnold, 196-211; Dawson, 301, 307. 
treated five miles to Saratoga (Schuylerville), where on the second morning he assembled his men and began the oct. 10 construction of new lines on the heights above Fish Creek. Gates followed him and soon completely sur- oct. 11 rounded him, the main body of the Americans on the south of Fish Creek, Poor's and Learned's brigades and Morgan's riflemen on the west of the British camp, Fellow's brigade on the heights across the Hudson and Stark in Burgoyne's rear at Fort Edward.

Burgoyne then called a council of war, himself, oct. 12 Phillips, Riedesel and Hamilton, and submitted five possible movements to his associates; but the only one that was seriously considered was a prompt retreat to Fort Edward. To accomplish this a start of four miles, unobserved, was deemed essential. Scouts were sent out, and on their return reported that the army was so surrounded that it would be impossible for it to march without being immediately discovered.

Burgoyne then called a second council of war, "con- oct. 13 sisting of all the general officers and field officers and captains commanding corps," and asked them whether an army was justified "in capitulating in any possible situation," and whether "the present situation is of that Negotiations for Surrender nature." Both questions were unanimously answered in the affirmative. An officer was then sent to Gates with a letter from Burgoyne asking a "cessation of arms" oct. 14 long enough to enable Burgoyne to state the terms "by which in any extremity he and his army mean to abide." Gates replied, naming his own terms, and granting a cessation of arms until sunset. The sixth article required Burgoyne's army to be paraded in their camps, ground their arms and be marched to the riverside on their way to Bennington. The council was reassembled 
$\mathbf{1 7 7 7}$ and unanimously rejected this article. An officer was sent back and at sunset delivered this ultimatum to Gates: "If General Gates does not mean to recede from the 6th article, the treaty ends at once. . . . The cessation of arms ends this evening." He also delivered the terms which Burgoyne was willing to accept. To the Oct. 15 surprise of every one, the next morning Gates sent an officer to Burgoyne, practically accepting the latter's terms, but stipulating that the conquered army should leave its position at 2 o'clock on that day. Gates had, in fact, just learned of the capture of Fort Montgomery and Fort Clinton and the advance of Vaughan up the Hudson. He was disposed to take the best terms he could get. But the stipulation about moving before 2 o'clock made Burgoyne suspicious. He determined to gain time, and appointed commissioners to arrange terms. Their negotiations continued until 11 P. M., at which hour the articles were agreed upon, the British commissioners giving their word that they would be oct. 15 signed by Burgoyne. But when they returned to their camp at midnight Burgoyne had just learned from a deserter that Fort Montgomery had been captured and that part of Clinton's army had reached Kingston. Burgoyne thereupon called his council together again and asked whether it was honorable to withdraw from a treaty definitely agreed upon by authorized commissioners; fourteen officers thought it was dishonorable and eight that it was not. Burgoyne refused to be bound by their decision, and agreed with the minority. ${ }^{1}$ He then asked

1 The minutes of the council are given in Burgoyne's narrative, Appendix, pp. cii to cv. General Riedesel also wrote out, on September 18, his memorandum of the negotiations. Riedesel's Memoirs, pp. 175-184. Stedman (I, 385-392) gives verbatim the letters that were exchanged between Gates and Burgoyne. 


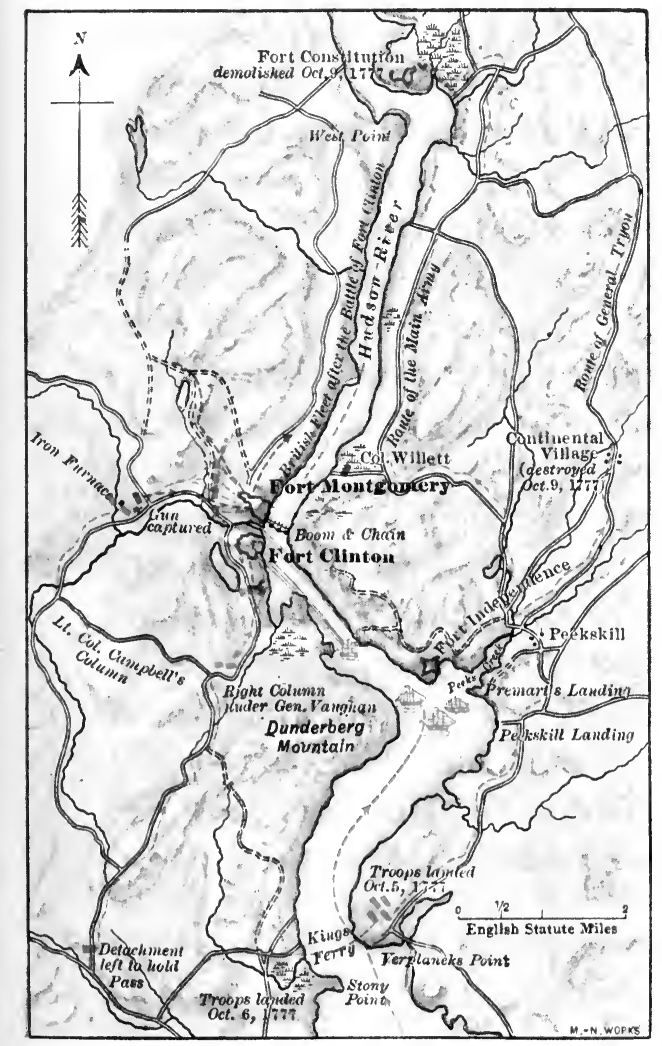

Forts Montgomery and Clinton Oct. 6, 1777

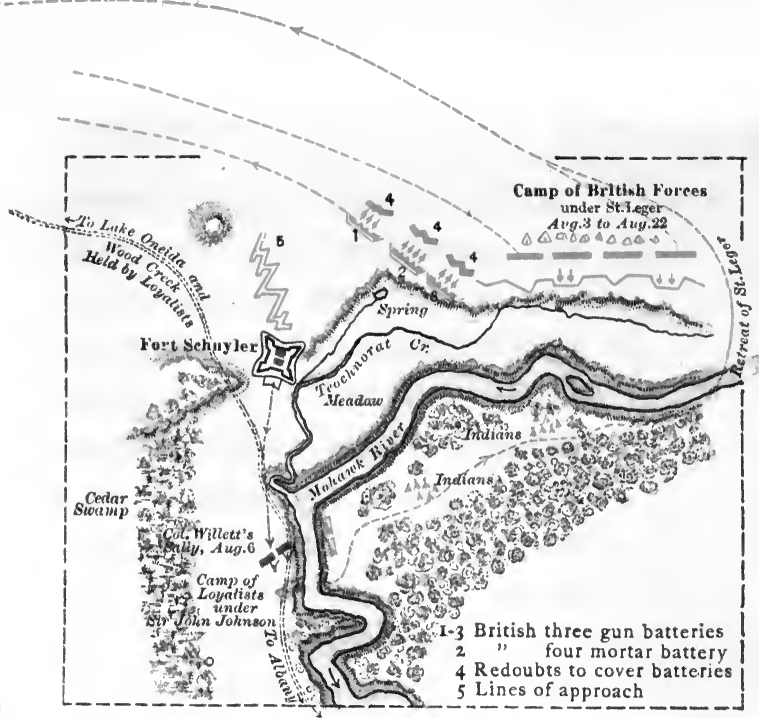

Fort SCHUYler

Aug. 3-22, 1777

Courtesy of The Burrow's Brothers Company, From Publishers, Cleveland, Ohio

From Avery's History of the United States and Its People

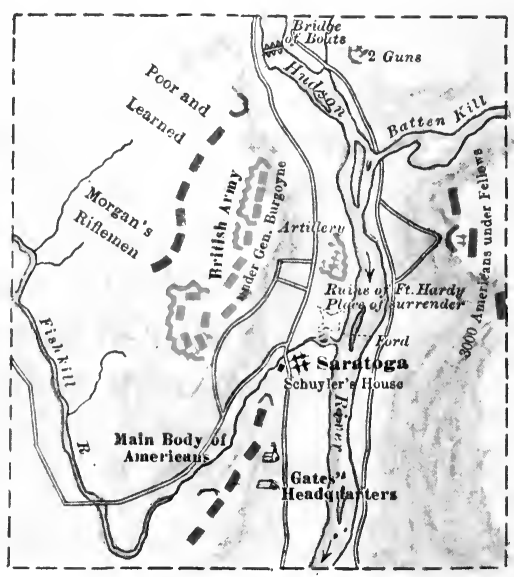

Surrender of Burgoyne

Oct. 17,1777 
$i{ }^{2}$

$\because \ldots$ 
whether the army would defend their position to the last

extremity. On this the opinions were conflicting, the majority inclining to the opinion that they would not. In order to gain more time, Burgoyne sent word to Gates early in the morning that he had heard that some of the American army had been sent to Albany, and in order to assure himself that he was surrounded by a force three or four times as numerous as his own, he wished to send one of his own officers to examine his force. This was more than Gates would stand, and he replied declining his request, saying that he would show his army after the convention was signed, warning Burgoyne of the consequences of refusing to sign the articles agreed upon by authorized commissioners, and telling him if they were not signed within an hour he would resort to extreme measures. Convention" Another council was then summoned, and, although opinions were still divided, Burgoyne decided to yield. He signed the articles ${ }^{1}$ and sent them to Gates, who signed them in turn.

The British and Hessians marched out of their camp oct. 17 the following afternoon, laid down their arms and then marched through the American camp, where the troops were paraded under arms and then on toward Albany. The return, drawn up that day, showed 341 officers, 586 non-commissioned officers and 4,836 privates, a total of Strength of the Surren$5,763 .{ }^{2}$ Burgoyne gives a detailed statement of his total losses during the campaign, amounting (among the regulars, exclusive of Canadians and Indians) to 415 killed, 911 wounded and 1,169 prisoners, a total of $2,495 .^{3}$

The garrison of Ticonderoga and Crown Point escaped

${ }^{1}$ The original document is in the possession of the New York Historical Society.

2 Dawson, 300.

${ }^{3}$ Burgoyne, LI. 
1777 to Montreal. The Hudson was free down to Spuyten Duyvil.

Ten times has the United States army received the capitulation of the armed force opposed to it, viz.: at Saratoga, Yorktown, Vera Cruz, City of Mexico, Donelson, Vicksburg, Appomattox, Durham's Station, Santiago and Manila. Saratoga was the first, and it gave rise to an unfortunate controversy which was not the case in any of the others. In his first proposals Gates stipulated that Burgoyne's army "can only be allowed to surrender [as] prisoners of war." But later he agreed to a "Convention" instead of a "Capitulation," and its thirteen articles said nothing of prisoners of war. The essence of the convention was that all the troops, of whatever country, under Burgoyne's command were "to march out of their camp, with the honors of war," and lay down their arms "by word of command of their own officers"; were then to march to Boston, and as soon as Howe should send transports to receive them, were to sail to England,

Controversy about the

"Convention Troops" "on condition of not serving again in North America during the present contest," unless they or any part of them should be exchanged by cartel. ${ }^{1}$ As a matter of fact they were never sent to England, but were kept at Boston for a year, then sent to Charlottesville, Va., and after that to Lancaster, Pa., and other places. Meanwhile each side charged the other with bad faith and a breach of the convention.

The real trouble was that under the convention it was possible to send Burgoyne's army back to England for garrison duty, releasing fresh troops for service in Ameroct. 20 ica. Burgoyne wrote a private letter to Germain, three

${ }^{1}$ The convention in full is printed in Dawson, 303, 304; Riedesel, I, 184-186. 
days after the surrender, calling attention to this possi1777 bility, and claiming great credit for "saving the army." ${ }^{1}$ Nov. 5 Gates seems not to have seen this point, but Washington's Nov. 13 clear mind saw it the moment he read the document, and he wrote to Heath, ${ }^{2}$ who commanded at Boston, pointing it out to him, and requiring him to insist on a rigid compliance by Burgoyne with his part of the terms. Howe did not like to send his ships so far away from New York, and presently he asked to have the point of embarkation changed to Newport; but Washington refused to make any change. ${ }^{3}$ If Howe could send his ships to Boston, and spare them for the long voyage to England, well and good; but there should be no change whatever Dec. 17 in the terms. The matter presently came up in Congress, and that body resolved that the embarkation should not take place until the convention was explicitly ratified by the court of Great Britain. It charged that Burgoyne 1778 had not surrendered all his "arms," because he had re- Jan. 8 tained or concealed his cartridge-boxes and colors, and Riedesel admits that he took the colors off their staffs, burned the latter and put the colors in his trunks. ${ }^{4}$ Howe complained that the prisoners were suffering for food and shelter, and Congress insisted that the British should pay for the provisions, and in gold at that, not in Continental currency. ${ }^{5}$

It was an unseemly controversy and many of the positions taken by Congress were not tenable; but it all arose from the trick by which Burgoyne tried to outwit Gates by a surrender which would result in bringing an equa'. number of fresh troops from England as fast as ships

\footnotetext{
${ }^{1}$ Burgoyne, XCVII.

${ }^{3}$ Ibid., V, 234, 535-538.

'Sparks, V, 144.

sour. Cont. Cong., IX, 1032; X, 35.

'Madame Riedesel's Memoirs, 161
} 
1777 could cross the ocean and back. The controversy dragged on for nearly four years, Burgoyne meanwhile going to England on parole, and taking his seat in Parliament where he defended before a committee his conduct while in America. More than four years after the surrender, in Dec. 17, 1781 a debate in the House of Commons on the American war, he complained that he was still a prisoner of war. ${ }^{1}$ During all these four years the subject of "convention troops" was in controversy both in and out of Congress. Finally Congress turned the whole matter over to Washington. ${ }^{2}$ In the meantime most of the officers and a large part of the men had been gradually exchanged; and others, particularly the Germans, were allowed to escape and settle in America, where they permanently remained, but some of them were still prisoners when peace came in $1783 .{ }^{3}$

The surrender of Burgoyne was of signal advantage to the American cause. It hastened the French alliance; it left the Hudson permanently in American control; it put out of action more than one-fourth of the King's forces in America. It has been sufficiently pointed out that Burgoyne's plan, which he persuaded the King and the ministry to adopt, although the latter failed to advise Howe of his part in it, was inherently wrong and inevitably doomed to failure. With the means of transportation then existing an army could not operate in a hostile country when separated from its base of supplies by 180 miles of wilderness. Even if Howe had carried out the part originally assigned to him, the British disaster might have been greater than it was; for, remembering what Washington accomplished at Trenton and at Yorktown,

${ }^{1}$ Hansard, Parl. Hist. of England, XXII, 862.

2 Jour. Cong., III, 46, 218.

'Sparks, VI, 257; Riedesel, II, 175. 
it is quite possible that in the event of Howe going up the Hudson to join Burgoyne, Washington might have taken New York, cut Howe off from his ocean base and captured his army as well as Burgoyne's. The plan which offered the greatest chance of success in the spring of 1777 was the one that King George "greatly disliked" 1 and that Washington, with clear military insight, anticipated and dreaded, viz.: to bring every man in America to New York, and with this overwhelming force to crush Washington. Could his army have been destroyed or scattered, the conquest of the Hudson and the separation of New England from the Middle States would have been an easy task.

${ }^{1} \mathrm{P} .78$, ante. 


\section{CHAPTER V}

\section{THE FRENCH ALLIANCE ${ }^{1}$}

1778

THE site of the encampment at Valley Forge is now an historical park owned by the State of Pennsylvania. The house occupied by Washington and the other stone houses in the vicinity are in substantially the same condition as they were during the terrible winter of 177778 ; the lines of intrenchments and the redoubts in or adjacent to the works can still be distinctly traced. ${ }^{2}$ They follow the contour of wooded hills, which rise at their highest point to an altitude of 354 feet above the waters of the Schuylkill on the north and Valley Creek on the west. To the eastward the hills slope gently into an open country, to the north the slope is more abrupt and to the west it is precipitous. The length of the "inner line" of intrenchments was about a mile and a half, and they enclosed an irregular triangle of about 500 acres between Valley Creek and the Schuylkill. But a large part of the troops were encamped, or hutted, outside of these lines for a distance of two miles to the eastward. From these positions, in case of attack, the troops

${ }^{1}$ The statue of Rochambeau in Lafayette Square, Washington, was unveiled in 1902; and in connection therewith Congress has published an elaborate memoir, edited by George de B. Keim, under the title of Rochambeau, which contains much original data, not hitherto available, concerning the French troops and ships.

See Annual Report Valley Forge Park Commission, 1906. 


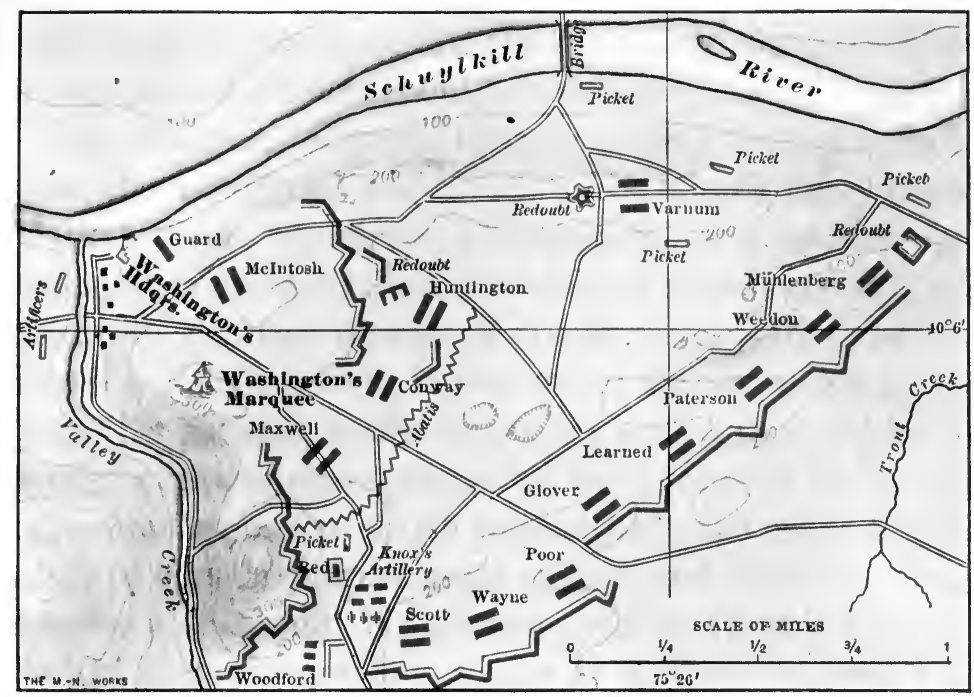

VALLEY FoRGE

Dec. 19, 1777-June 17, 1778

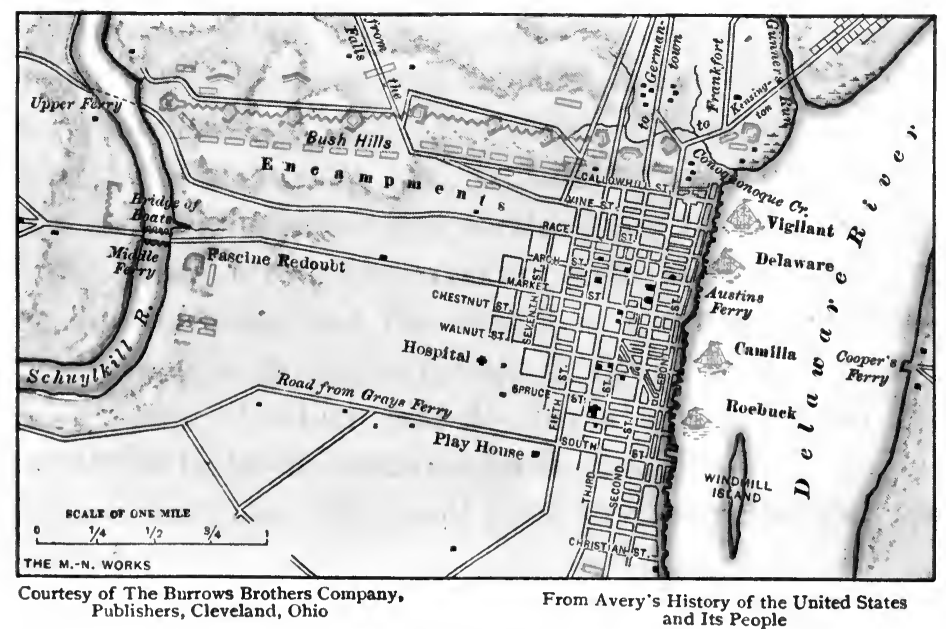

Philadelphia

Evacuated June 18, 1778 

could quickly retire within the main lines behind which

a very strong defence could be made.

The distance, following the windings of the Schuylkill, from the mouth of Valley Creek to the Middle Ferry (now Market Street bridge in Philadelphia) was twenty-one miles; and by road, from Washington's outposts at Port Kennedy (at the mouth of Trout Creek) to those of Howe at Germantown, it was about sixteen miles.

In this position, easily defensible, with a rich and longsettled agricultural region at his back from which to obtain supplies, and in which were already the crude beginnings of what is now the great mineral and manufacturing district of Reading, Washington was on Howe's flank as he had been the previous winter at Morristown, and was prepared quickly to follow Howe should he make any move.

The American army remained at Valley Forge just six months-months of intense anxiety for the commanderDec. 19,1777 , to June 18 , in-chief and of terrible suffering for his men. It was destitute of shoes, clothing and provisions; it was not properly organized; it was deficient in knowledge of drill and manœuvres; it had no proper system of accountability; its regiments and battalions were mere skelePrincipal tons and recruits were not forthcoming to fill them up. ${ }^{1}$ While Washington was working with all his energy to remedy these defects the wretched Conway Cabal was equally active in contemptible intrigues with Congress, the purpose of which was to displace Washington and substitute Gates as commander-in-chief.

These were also months of great events in Europe; the

1 The terrible winter at Valley Forge has been described in every history of the Revolution. Perhaps the most vivid picture of it is that given in Trevelyan, III, 294-302. 
1778 conclusion of the French alliance; the adoption by the

Feb. 6

March

April

Feb. 8

March 8

March 21

Dec. 22

Dec. 23

Conway Cabal British ministry and King of measures offering to the Colonies everything they had asked for except independence; the despatch of commissioners to treat with Congress for peace on these terms; the resignation of Howe and the appointment of Sir Henry Clinton in his place; and the sending of instructions ${ }^{1}$ to Clinton that "the war must be conducted on a different plan," the offensive to be abandoned, part of his force to be sent to the West Indies to attack the French at St. Lucia, part to Florida to retain the British possessions there, part to harry the New England coast towns, Philadelphia to be evacuated, everything to be concentrated at New York, and if in danger there-scuttle for Halifax. ${ }^{2}$

The campaign of 1777 marked the end of all active operations by the British in the Northern States. The war was to last five years longer, but the British strength was to be frittered away in disjointed movements at great distance from each other; and although the force at New York was to be maintained at a strength always at least fifty per cent greater than the Continentals under Washington, it was to remain all those years strictly on the defensive.

At the beginning of the winter Washington wrote to Congress $^{3}$ two letters which conveyed a most graphic picture of his starving and naked army. Congress appointed a committee ${ }^{4}$ to go to Valley Forge; it remained there for several months, and in concert with it Washington formulated plans for overcoming the defects above enumerated. As to the Conway Cabal, it was a contest of pygmies against a giant. Washington shattered and

\footnotetext{
${ }^{1}$ Sparks, V, 395, 548-551. $\quad{ }^{2}$ Germain to Clinton, Sparks V, 550.

'Ibid., V, 192-203. "Jour. Cont. Cong., IX, 1052.
} 
destroyed it by the sheer force of his lofty character and great services. Gates, indeed, had strength enough to secure his appointment two years later to the command of the Southern army, where, having no Arnold to lead his troops as at Saratoga, he speedily proved, to the complete satisfaction of all concerned, his shallowness and incapacity. But Mifflin, Conway and the rest were more quickly disposed of; Mifflin being without military employment for nearly a year, then resigning and going to Congress where he had no influence; Conway, wounded in a duel, resigning his commission in the army, writing an abject apology to Washington and finally returning to Europe and disappearing forever from public view. ${ }^{1}$ No one ever ventured again to dispute the fact that Washington was the one indispensable man for the success of the Revolution, or to suggest any other name for the position of commander-in-chief.

As to the more distinctly military problems at Valley Forge, Washington solved them one by one, so that when the army moved in June it was in a condition of military efficiency which it had never before approached. The most pressing questions were food and clothing. The country was not deficient in either, and the responsibility for the destitute condition of the army was partly due to the unwise action of Congress and partly to the hopeless inefficiency of the quartermaster's department. The delegates in Congress, seldom more than twenty-five present, were very jealous of a standing army, but they did not hesitate to pass the most despotic resolutions. ${ }^{2}$ Sept. 17 Among others they ordered Washington "to take, wher- Nov. 14 ever he may be, all such provisions and other articles Dec. 10

${ }^{1}$ Sparks, V, 517.

'Ibid., V, 187, 406. 
1777 as may be necessary for the comfortable subsistence of the army under his command, paying or giving certificates for the same"; ${ }^{1}$ but it made no adequate provision for paying the certificates. To enforce this impressment with the utmost rigor was to deprive the army of the support of the people. Washington exercised the despotic powers conferred upon him by this and previous resolutions with great prudence and much less vigorously than Congress demanded. ${ }^{2}$ Such supplies as he did seize were never at the place wanted, for Mifflin, the quartermastergeneral, had for six months practically abandoned the duties of his office, ${ }^{3}$ and his department was in complete disorder. ${ }^{4}$ In concert with the committee, Wash-

Greene Appointed pointed
Quartermaster-
General

March 23

\section{8}

Washington to Greene, August 15, 1780 ington prevailed upon Congress ${ }^{5}$ to make better provision for payment of the certificates; and jointly they persuaded Greene, much against his will, to perform the duties of quartermaster-general without vacating his position in the line. Having accepted the task, he bent every energy to its successful accomplishment. Before the army moved in June he had established a line of depots or magazines of supplies in rear of the army from the Head of Elk to the North River, ${ }^{7}$ and as Washington expressed it, "by extraordinary exertions you [he] so arranged it as to enable the army to take the field the moment it was necessary, and to move with rapidity after the enemy." 8

The deficiencies in drill, organization, discipline and

1 Jour. Cont. Cong., VIII, 752; IX, 905, 1014.

${ }^{2}$ Sparks, V, 187, 188.

${ }^{3}$ G. W. Greene, II, 20, 43, 49.

' Report of committee of Congress, February 12, 1778. Original is in handwriting of Joseph Reed; a complete copy is published in Life and Correspondence of Joseph Reed, I, 360.

J Jour. Cont. Cong., X, 210, 223, 224, 325.

- Ibid., X, 210.

${ }^{7}$ G. W. Greene, II, 57.

${ }^{8}$ Sparks, VII, 153. 
accountability were overcome by the fortunate arrival of 1778 a thoroughly competent man, Steuben, who had served Feb. 23 at Prague and Rossbach and the other battles of the Seven Years' war, on the personal staff of the great Frederick. Steuben He joined Washington as a volunteer, and later, when he had proved his entire competency for the position, he Appointed InspectorGeneral was appointed inspector-general of the army. ${ }^{1} \mathrm{He}$ in- May 27 troduced a definite plan (which Congress subsequently approved) of organization in the infantry, artillery, cavalry and engineers; he devised a system of accountability for public property which resulted in enormous saving; he taught the troops how to take care of their arms; he gave them their first drill-book ${ }^{2}$ and regulations for troops in active service; he personally drilled them until they could execute manœuvres with creditable exactness. $^{3}$ It was to do these things that he had been selected and sent over by the French ministers." In view of their plans to aid the American cause with men, munitions and money, they wished to improve the military efficiency of the American army. There was probably not a man in the whole world more competent for this task than Steuben.

In order to increase the strength of his army, Washington succeeded, in spite of much insubordinate opposition on the part of Gates and Putnam ${ }^{5}$ in bringing to Valley Forge the greater part of the Continentals that Washington to Putnam, had been at Saratoga. The militia, which had formed more than half of Gates's army, went home soon after

\footnotetext{
${ }^{1}$ Kapp, Steuben, 52, 192-273; Sparks, V, 526, 529; Jour. Cont. Cong., XI, 465, 514, 538, 543, 550.

${ }^{2}$ Kapp, Steuben, 200-214.

I Ibid., 52, 192-273.

Ibid., 68, 69; Sparks, V, 527.

${ }^{5}$ Sparks, V, 125, 161, 162; Sparks, Letters, II, 536-544.
} 
1778 the surrender. Moreover, these Continentals, like those already at Valley Forge, were depleted to a mere fraction of their normal strength. In order to fill up the ranks, Congress, which had hitherto "recommended" to the States to furnish their quota, now undertook to "require

Recruits for the Army, Feb. 26, 1778 forthwith" the States to do this by means of a draft." Effectually to carry out a draft required powers and administrative organization far beyond those possessed by the Congress under the Articles of Confederation; and it is probable that the personal appeals which Washington made all through this winter and spring to the governors of States, Jonathan Trumbull in Connecticut, George Clinton in New York, Thomas Wharton in Pennsylvania, Patrick Henry ${ }^{2}$ in Virginia, and others, had more effect than the resolutions of Congress, however commanding their language might be. Between them all, however, a certain number of recruits were obtained. The committee of Congress led Washington to believe that the 104 battalions (16 Continental and 88 State "line") which existing laws then authorized would produce an army of 40,000 men for the year's campaign. ${ }^{3}$ In fact they produced barely half that number.

As for the British Peace Commission, headed by the Earl of Carlisle, which arrived at Philadelphia, it was two years too late. The French alliance bound each country not to make peace without the consent of the other, nor without acknowledgment by Great Britain of the independence of the United States. ${ }^{4}$ Congress refused to

1 Jour. Cont. Cong., X, 200.

2 Sparks, IV, 477; V, 9, 146, 239, 252.

'Ibid., V, 314.

- Treaty of Alliance, February 7, 1778. Treaties and Conventions of the United States, 308. 
treat on any other terms, ${ }^{1}$ and the mission was a ridiculous failure.

The motives which induced France to make the Feb. 6 alliance cannot be discussed here. The signing of the treaty was due to the campaign of 1777 , resulting in the capture of Burgoyne's army on the Hudson and to the fierce, if inconclusive, battles around Philadelphia. It necessarily involved the prompt despatch to America of French a considerable land and naval force by France.

At the beginning of June, therefore, Clinton, who had May 11 relieved Howe in the command, began to make preparations for evacuating Philadelphia. Washington was watching him like a hawk. As at Trenton, his service of information seems to have been remarkably efficient. Everything of importance that transpired in Philadelphia, either in the way of events or of plans under discussion, came to the knowledge of Washington within forty-eight hours or less. ${ }^{2}$

At this time the British force in the United States numbered 33,756 ; made up of 18,174 British regulars, Strength of Opposing 11,007 Hessians and 4,575 Provincials; and they were stationed, 19,530 at Philadelphia, 10,456 at New York March 26 and 3,770 at Newport. ${ }^{3}$ The American regular force, or "Continental line" and the State "lines," according to the returns which Washington laid before a council of war, were about 15,000 , of whom 11,800 were at Valley Forge, 1,400 at Wilmington and 1,800 on the Hudson. Washington thought that he could get enough additional recruits to bring the entire force up to 20,000. At this

1 Jour. Cont. Cong., XI, 701, 702.

'Sparks, V, 377, 393, 409.

3 The returns of the British army, copied from the State Paper Office in London, at various periods from 1777 to 1782, are given in Sparks, Writings of Washington, V, 542-545. 
council, after a long discussion, it was decided not to May 8

May 18 attack Philadelphia, but to wait events. ${ }^{1}$ The army at Valley Forge was organized into four divisions under Greene, Stirling, Lafayette and Wayne. Lee, who had recently been exchanged, was again on duty as second in command. Steuben was inspector-general.

With a view to watching the first move in the expected evacuation of Philadelphia, Washington threw out an advance guard between the Schuylkill and the Delaware. ${ }^{2}$ It was composed of Lafayette's division, numbering about 2,100 men and 5 guns. They advanced to a hamlet known as Barren Hill, about 11 miles from Valley Forge and only 2 miles from Clinton's outposts at Chestnut Hill. In selecting Lafayette, who was not yet twentyone years old, for this important duty, Washington doubtless intended a compliment to France. But within fortyeight hours he was in mortal dread lest the outcome might be anything but pleasing to France. For, from the top of the high hill at Valley Forge, he saw, across the rolling ground between him and Barren Hill, the smoke of skirmishes and the dust of marching columns, which showed that the young marquis was in full retreat toward a ford on the Schuylkill and in imminent danger of being cut off.

Clinton had, in fact, planned to capture Lafayette and came very near doing it. He had sent Grant with about 5,000 men via Whitemarsh to come in rear of Lafayette's left, Grey with about 2,000 men to cross the Schuylkill and come behind Lafayette's right, while with a considerable force under his own command he marched through Germantown and Chestnut Hill to attack Lafayette in

${ }^{1}$ Sparks, V, 360.

${ }^{2}$ Washington's instructions to Lafayette, Sparks, V, 368. 
front. These movements were made during the night; 1778 and early the next morning Lafayette was nearly sur- May 20 rounded by a force about five times greater than his own. He extricated himself from this dangerous situation with no little adroitness; ${ }^{1}$ and although Grant was nearer to Matson's ford (now Conshohocken) than Lafayette was, the latter, by skilful feints of his rear guard against both Grant and Clinton, marched by the longer road (through Manatawna), got past the head of Grey's column and crossed Matson's ford (Conshohocken) in safety. He took a strong position on the heights on the south bank of the Schuylkill, while Washington assembled every man at Valley Forge to march to his assistance. Thanks to Steuben's drills, they were all under arms in fifteen minutes. But notwithstanding his enormous superiority in force, Clinton did not cross the ford nor attack. He retired almost immediately to Germantown; and Lafayette returned to Valley Forge. Clinton lost 2 men killed and 7 or 8 wounded, and Lafayette's losses were about the same.

The foolish Mischianza in honor of Howe took place the May 18 same day that Lafayette moved to Barren Hill; and a May 25 week later Howe sailed for England. Clinton began loading his transports with his heavy baggage, and early in June several vessels had dropped down the river. Washington was fully informed of this; he was more than ever on the alert; frequent councils of war were held; and preparations were made to move promptly as soon as Clinton made any movement. ${ }^{2}$

Finally, the transports being loaded with all they could Evacuation of carry, including some cavalry and the Anspach regiment, 
1778 which it was feared would desert on the march, ${ }^{1}$ Clinton

June 18,

3 A. M.

10 A. M.

June 19,

Washington

Marches from

Valley Forge

June 24 assembled his troops just south of Philadelphia, crossed the Delaware to Gloucester Point and marched out to Haddonfield, 5 miles. ${ }^{2}$ Washington had information of this within a few hours; and early in the afternoon 6 brigades, 3 under Lee and 3 following under Wayne, had marched from Valley Forge. Washington with all the rest of his army marched at 5 o'clock the next morning. This was the first fruit of Greene's work as quartermaster and Steuben's as drill-master.

Washington believed that Clinton would move to New Brunswick, cross the Raritan, then march to Amboy and cross the Kills to Staten Island. ${ }^{2}$ Such was exactly Clinton's plan. It was therefore a race for New Brunswick, and a very pretty race it was. The distance was 58 miles from Philadelphia, 66 miles from Valley Forge. The roads were rather better on Washington's line of march; the weather was the same for both-intense heat (the thermometer exceeding $100^{\circ} \mathrm{F}$. in the sun) alternating with violent showers.

On the sixth day Clinton had advanced only 34 miles, and was in the vicinity of Allentown, ${ }^{2}$ about 10 miles east of Trenton. Washington was squarely in front of him, ${ }^{3}$ having marched 47 miles, crossing the Delaware at Coryell's ferry (Lambertville), 15 miles above Trenton; his main body was north and east of Princeton, and Maxwell's brigade and the New Jersey militia were in contact with Clinton, ${ }^{4}$ breaking down the bridges, blockading the roads and otherwise obstructing his march.

Clinton therefore had to change his plan and make Sandy Hook instead of New Brunswick his objective.

1 Lowell, Hessians, 212.

'Sparks, V, 409, 411, 416, 422-423.
' Clinton's Report, Dawson, 415.

Ibid., V, 423. 
He put all his baggage, wheeled vehicles and pack-horses under Knyphausen; and turning to the right at Allen- The Two town he sent them forward on the road which leads contact through Freehold village, or Monmouth Court House, to Sandy Hook. Hitherto he had been able to move his columns on parallel roads, but now he had only a single road, and his impedimenta stretched out for a length of 12 miles. The armed force with Knyphausen consisted of a regiment of cavalry, a battalion of light infantry, 2 brigades of British, 2 brigades of Hessians, and some Provincials. In spite of the heat and the deep sandy roads, Knyphausen reached Freehold-19 miles-on the second morning. ${ }^{1}$ Clinton followed $\mathrm{him}^{2}$ with a regiment of cavalry, a battalion of light infantry, 3 battalions of June 26 grenadiers and 3 British brigades. He arrived at Freehold the same afternoon.

The whole force then rested a day in a fairly strong defensible position on both sides of Monmouth Court House, ${ }^{2}$ June 27 their flanks protected by pine woods and their front by streams and morasses.

Washington on the previous day was at Cranberry, 8 miles east and south of Princeton, with his main body; and his advance guard of nearly 4,000 men, under Lafayette, was on the Monmouth road about 5 miles in rear of Clinton, with orders to attack their rear guard. But as Lafayette was too far separated from the main body, Washington drew him off to the north toward Englishtown, 6 miles west of Monmouth. At Lee's request Washington sent him with two more brigades to join Lafayette; and on his arrival Lee, as senior officer, was in command. ${ }^{3}$

${ }^{1}$ Clinton's Report, Dawson, 415.

${ }^{2}$ Sparks, V, 424.

s Ibid., V, 423. 
1778 At the close of this day, therefore, the positions were as follows: Clinton and Knyphausen, about 15,000 men, on the Monmouth plain and the hills just south of it, facing west; Lee with the advance, 5,000 men and 12 guns, at Englishtown; and Washington with his main body, 6,000 men, between Cranberry and Englishtown.

About 10 or 12 miles north of Monmouth (Freehold) the country is broken, the Middletown hills rising to an altitude of about 400 feet and affording a number of good defensible positions. Washington was very anxious to attack Clinton while he was still in the low ground and

June 27

Battle of Monmouth

June 28

5 A. M.

8 A. M.

10 A. M.

11.30 A. M. before he could reach these hills. He therefore sent explicit orders ${ }^{1}$ that evening to Lee to have his men in readiness for attack, intending to march with the main body at daylight to his support.

The next morning Knyphausen resumed his march, and as soon as his column was stretched out Clinton followed. ${ }^{2}$ Washington heard of it and put his own troops in motion at sunrise, at the same time sending an order to Lee to attack Clinton. Lee moved forward rather leisurely, and began a skirmish with Clinton's rear guard about a mile north of the Court House; but instead of making a vigorous attack he gave a number of contradictory orders and then ordered a retreat. ${ }^{3}$ The officers and men were astonished, and fearing that something was wrong the retreat soon became disorderly. Washington, galloping ahead of his main body, met the fugitives about three miles east of Englishtown ${ }^{4}$ and the same distance west of the Court House where Lee had had his

${ }^{1}$ Sparks, V, 420, 424, 425.

2 Clinton's Report, Dawson, 416.

${ }^{3}$ Sparks, V, 420, 424, 425. ${ }^{4}$ Ibid., V, 419. 
skirmish. He soon encountered Lee, and there is little 1778 doubt that Washington's passionate nature, which he usually controlled by his strong will, for once got the Battle of Monmouth, better of him. All accounts agree that strong language was used, but the exact words are in dispute. Dawson quotes Lafayette as saying - on his visit to Vice-President Daniel D. Tompkins at his house in New York on August 15,1824 , forty-six years after the event-that Washington called Lee "a damned poltroon." 1 If ever profanity is justifiable, it was then. Here were the fruits of Washington's labors with the committee of Congress to establish Lee. the army on an efficient basis, of Greene's work as quartermaster to put it in condition to march, of Steuben's instruction in drill and discipline-all in danger of being lost by the combined incapacity, cowardice and treason of this damnable Charles Lee. While Arnold, two years later on the Hudson, planned an infamous stroke which, had it succeeded, might have proved serious, yet what Arnold actually accomplished in injury of the American cause was but a slight fraction of the mischief caused by Lee on this hot Sunday morning at Monmouth. In spite of Clinton's numerical superiority, had Lee attacked him vigorously and held him at the Court House until Washington came up, Washington would have passed around Clinton's right flank between Monmouth and Middletown, penetrated between Clinton and Knyphausen and in all probability have captured a large part of Clinton's command.

But the mischief was done, and, without wasting more words on Lee, Washington rode forward toward the rear of the retreating troops and personally halted and reformed them, establishing a line, north and west of the

1 Dawson, 408. 
parsonage, between the two morasses. ${ }^{1}$ Clinton meanwhile had turned back all his own force and had sent to Knyphausen for a regiment of cavalry and a brigade of infantry. ${ }^{2}$ With this combined force he deployed on both sides of the road from Monmouth to Englishtown and attacked the line which Washington had established between the two morasses. ${ }^{3}$ But the main body had now arrived; and it went into action, Greene on the right, Stirling on the left and Washington himself in the centre, on the road. Severe fighting continued throughout the 1 to 5.30 Р. м. blazing afternoon-so intense was the heat that many men on both sides dropped dead without being wounded. ${ }^{4}$ Clinton first tried to turn the American left, then their right; each time without success. Finally, LieutenantColonel Monckton led his grenadiers in a fierce assault against Wayne, who was posted in an orchard on an eminence on the north side of the road, about 400 yards north of the parsonage. Monckton was killed and the attack failed. ${ }^{5}$

Toward sunset the British retired a short distance to reform and take up a strong defensive position with both flanks protected by small streams. Simultaneously Washington withdrew to the west side of the west morass or ravine, intending to reform his men and attack Clinton

${ }^{1}$ Most of the maps in Sparks's Writings of Washington are fairly accurate. But the one in Vol. V, p. 430, is very defective in topography and otherwise. It was copied into Lossing, Irving and other histories and was probably the cause of much of the difficulty expressed by various writers as to understanding the battle of Monmouth. The accompanying map gives the topography as delineated on the maps of the U. S. Geological Survey; and the positions of the troops are based upon Dawson's and Carrington's analyses of the testimony at the court-martial of Lee.

${ }^{2}$ Clinton's Report, Dawson, 416; Carrington, Battles of American Revolution, 423-449.

' Clinton's Report, Dawson, 416.

- Sparks, V, 426, 427.

${ }^{5}$ Lossing, II, 157. 


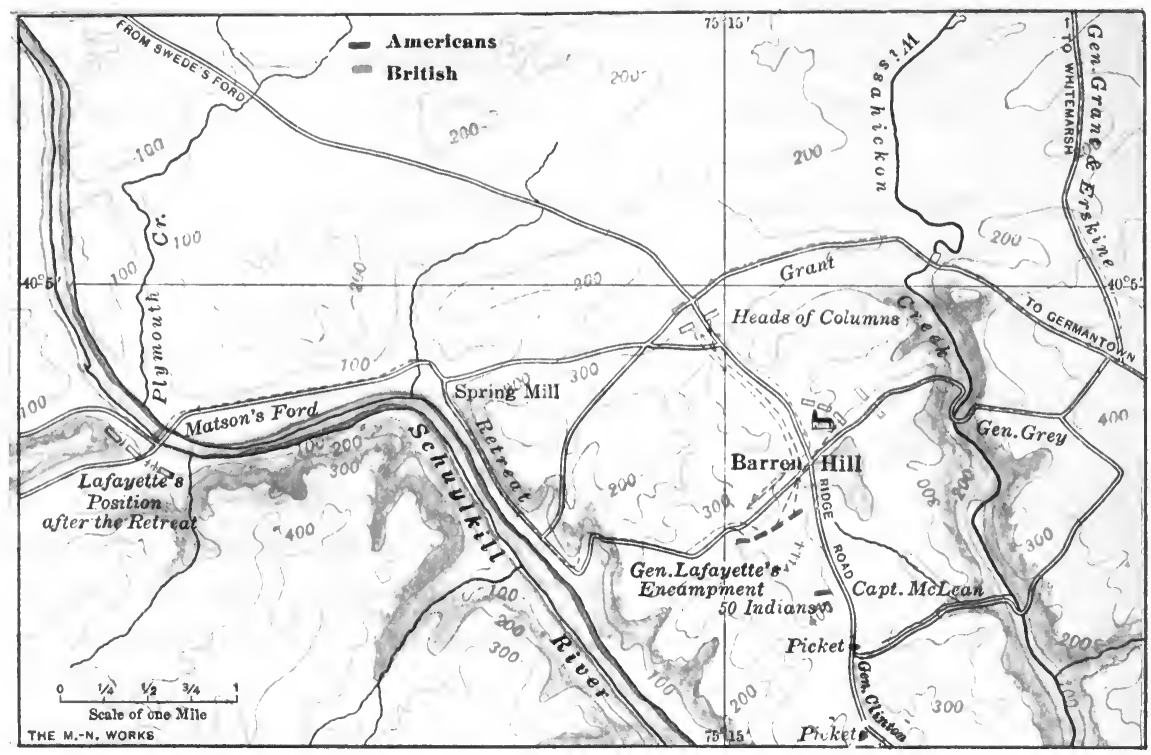

BARREN HILL

May 20, 1778

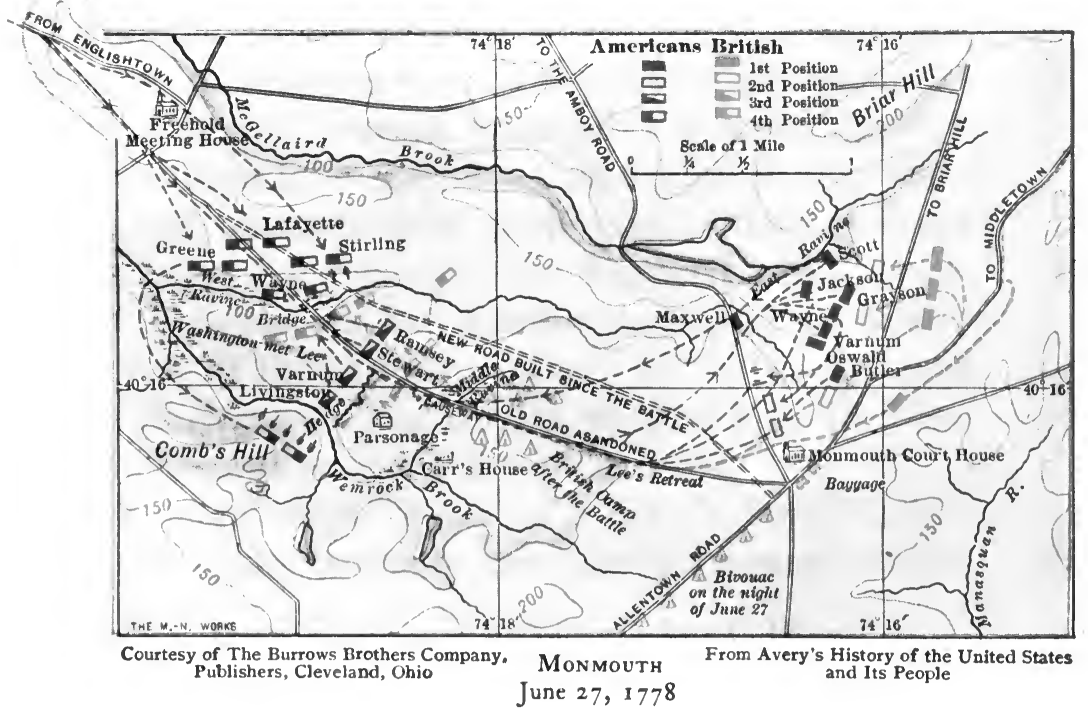




$$
\begin{aligned}
& \therefore \text { ? } \\
& \text { - ¿ : : } \\
& \text {, } \because \vdots \\
& \because:
\end{aligned}
$$


on both flanks. But night came on before these disposi1778 tions could be perfected, and the attack was postponed until morning.

When day broke the British had disappeared; ${ }^{1}$ they June 29 had moved at midnight and were well on their way to the Middletown heights. Although in close contact with the enemy, the American troops had slept so soundly, exClinton hausted with the intense heat and the battle of the previous day, that they had not heard the British as they moved away. In the broken country of the Middletown heights there was no chance of successful assault, and Washington therefore did not pursue. Clinton reached Sandy Hook in safety, ${ }^{2}$ and simultaneously Lord Howe arrived with his ships from the Delaware. On these the troops were transported up the bay to New York. ${ }^{3}$

Clinton reported his losses at 124 dead, 170 wounded and 64 missing; and he claimed that nearly half his dead had perished from the heat. But Washington stated that the number of British buried-" according to the returns of the parties assigned to that duty"-was $249 .^{4}$ He wrote to Arnold-who, on account of his wound received at Bemis' Heights, was unable to move with the army and had been sent into Philadelphia to take command and perserve order there-that Clinton's losses during his retreat must have been at least 2,000 , including 600 Hessians who had deserted during the march and gone back to Philadelphia, thenceforth to become good American citizens. Washington reported his own losses at 58 killed, 161 wounded and 131 missing. ${ }^{4}$

Washington's army remained a few days at Englishtown, and thence moved by easy marches through Bruns-

${ }^{1}$ Sparks, V, 427, 428, 429.

${ }^{3}$ Mahan, 360.
${ }^{2}$ Clinton's Report, Dawson, 417.

'Sparks, V, 428; Dawson, 415. 
1778 wick and Paramus to the Hudson, crossed the river at

July 21

Court-Martial of Charles Lee

Dec. 5

Jan. 10,1780

\section{Haverstraw and established itself at White Plains.}

Charles Lee was promptly put in close arrest and brought to trial for disobedience of orders, misbehavior before the enemy and disrespect to the commander-inchief. $^{1}$ The court-martial moved with the army, holding its sittings from day to day for a period of six weeks. The court found him guilty of all three charges, and imposed the ridiculously inadequate sentence of suspension from rank for twelve months. The proceedings went to Congress for ratification, and that body held it under consideration for nearly four months. Then, by a vote of 16 to 7 (Massachusetts, under the lead of Samuel Adams, and Georgia voting No; New Jersey, Maryland and Virginia being divided and casting no vote, and six States, Rhode Island, Connecticut, New York, Pennsylvania, North Carolina, South Carolina voting Ay), Congress grudgingly directed the sentence to "be carried into execution." ${ }^{2}$ Just as his sentence was expiring, Lee committed the heinous offence of writing a disrespectful letter to Congress, whereupon that body, without a roll-call, unanimously passed a resolution that they "have no further occasion for his services in the army of the United States." 3 Lee retired to his farm in Virginia and occupied the remaining six years of his life in making scurrilous attacks upon Washington and writing a blasphemous will. ${ }^{4}$

While Clinton was retreating from Philadelphia to New York-and for many weeks before-a French squadron

${ }^{1}$ Court-Martial of Charles Lee, printed by order of Congress, August 21, 1778. Reprinted in 1823 and 1824. Jour. Cont. Cong., XII, 1287.

2 Jour. Cont. Cong., XII, 1195.

3 Jour. Cong., III, 421.

'Sparks, V, 552-558; VI, 309; Life and Memoirs of Charles Lee, 160 
of 12 ships of the line and 5 frigates, mounting 834 guns

and carrying 4,000 soldiers, was on its way across the Atlantic. It had sailed from Toulon and after a voyage April 15 of 84 days had arrived at the capes of the Delaware. ${ }^{1}$ July 8 Lord Howe, who commanded the British fleet and transports, had been gone 10 days. ${ }^{1}$ He knew that the French fleet was on the way, and he had thrown into the work of loading Clinton's transports and moving them to New Arrival of the York that necessary energy of which his brother Sir William had shown so great a lack. The commander of the French fleet was Comte d'Estaing, who had served in the army until his thirtieth year and then been transferred to the navy "with the premature rank of rearadmiral." He lacked the sailor's training, and his captains were jealous of him. ${ }^{2}$

After sending the French minister up the Delaware in July 11 one of his ships, d'Estaing sailed northward and anchored in the ocean just south of Sandy Hook. Washington sent his aides, ${ }^{3}$ first Laurens and then Hamilton, to welcome d'Estaing and explain his views as to co-operation. Lord Howe, having carried Clinton's army to New York, hastened back to his ships and anchored inside the Hook. The two fleets were in plain view of each other, across the low narrow strip of sand just south of the Hook. Lord Howe had only 9 ships of the line to d'Estaing's 12, and 534 guns to his 834; but he was a sailor-as d'Estaing was not ${ }^{4}$-and he was determined to dispute the entrance of the French fleet to the last.

D'Estaing remained there eleven days. In letters to Washington and to Congress, filled with profuse com-

1 Mahan, 359, 360; Sparks, V, 440.

${ }^{2}$ Chevalier, Hist. de la Marine Française, quoted by Mahan, 371.

${ }^{3}$ Sparks, VI, 1-5.

4 Mahan, 360, 363, 364. 
1778 pliments, he explained the difficulty of crossing the bar, and said that he offered the pilots 50,000 crowns $^{1}$ if they would promise success. But Mahan says that "d'Estaing's heart failed him under the discouragement of the July 22 pilots; he gave up the attack and stood away to the southward." Mahan intimates that with Nelson or Farragut in d'Estaing's place, the result might have been very different. Probable it is that if d'Estaing had smashed the British fleet in New York and united his 4,000 soldiers to those of Washington on the north side of Harlem River, Clinton's army-on Manhattan Island and without ships-would have been caught like rats in a trap, and not a man would have escaped.

Attack on Newport

It had been arranged between d'Estaing and Washington's aides ${ }^{2}$ that if it was not feasible to cross the bar at Sandy Hook a combined land and naval movement should be made against Newport, where General Pigott was in command of about 3,000 men, part of those who had captured Newport under Clinton in 1776. ${ }^{3}$ D'Estaing sailed thither and at the end of a week anchored off Point Judith. ${ }^{4}$ Sullivan had been in command at Providence since the adjournment of the court which had inquired into his conduct at the Brandywine and on Staten Island and had acquitted him. He had about 1,000 Continentals under his command, and Washington wrote to him "to apply in the most urgent manner in my [his] name" to the New England States to raise 5,000 militia-or more. The militia turned out so promptly that within thirty days Sullivan had 7,000 of them, with John Hancock at July 22 their head. Washington then put Lafayette in com-

${ }^{1}$ Sparks, VI, 12.

${ }^{2}$ Sparks, VI, 12; Sparks, Letters, II, 155, 159.

3 Page 62, ante.

4 Mahan, 361. 


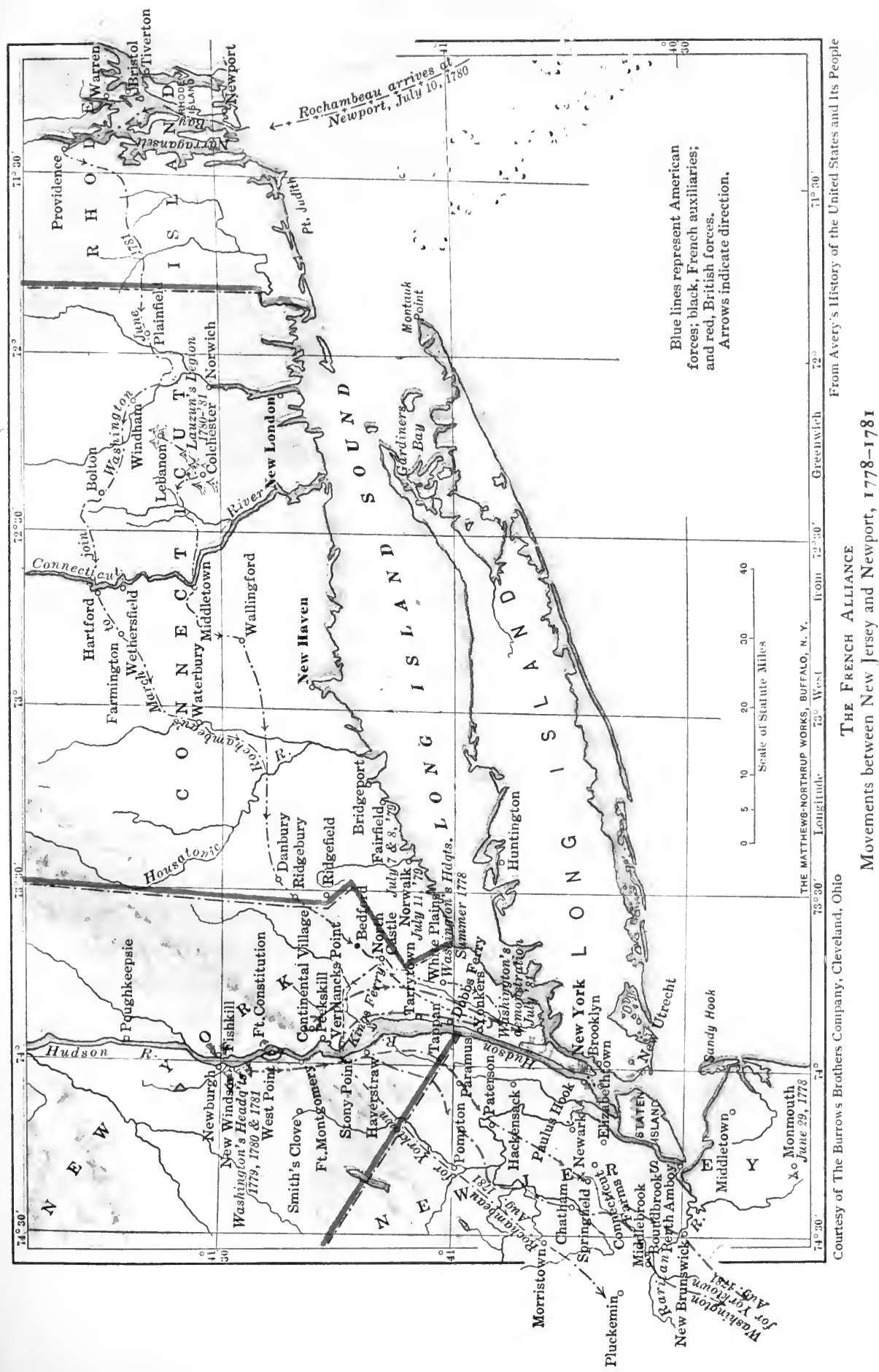




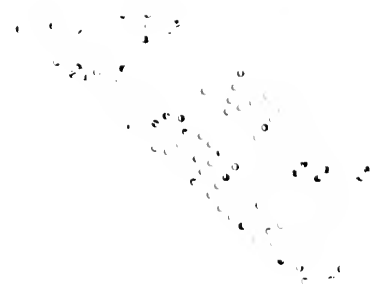


mand of two brigades and directed him to march to 1778 Providence; and a few days later he sent Greene to July 27 Rhode Island (his own State) and instructed Sullivan that his entire force, Continentals and militia, was to be divided into two divisions, of which Greene would command one and Lafayette the other. ${ }^{1}$

The result of these dispositions was to assemble a force of about 10,000 men under Sullivan's command. Unfortunately they did not arrive until about ten days after d'Estaing; and when d'Estaing sailed into Narragansett Bay, between Newport and Jamestown, and was pre- Aug. 8 paring to land his soldiers a few miles north of Newport, and join Sullivan who had brought his troops to the same point, Lord Howe appeared off Point Judith. ${ }^{2}$ With his customary energy he had sailed from New York for Newport as soon as he heard that d'Estaing had gone there. When the latter saw the masts of Howe's ships in the distance, he promptly decided to fight the British fleet before aiding Sullivan. Sullivan protested, but the French captains were a unit in insisting upon it; and when the wind changed to the north-east d'Estaing aug. 10 sailed out to meet Howe. ${ }^{3}$ He carried his 4,000 soldiers with him; but why he should have wished to be encumbered with them in a naval action has never been explained. The two fleets manœuvred off Block Island Aug. 12 for the weather-gage for nearly two days, and then a furious gale arose and scattered both French and English ships. Several ships were dismasted, and the damage was so serious that Howe had to return to New York. D'Estaing came back to Newport, but only to announce aug. 20

${ }^{1}$ Sparks, VI, 6.

2 Mahan, 361-364; Sparks, 29, 40, 41; Sparks, Letters, II, 176-179.

S Sparks, VI, 29. 
1778 his intention of proceeding to Boston for repairs. ${ }^{1}$ Greene and Lafayette urged him to land his troops and attack the British; after that he could refit his squadron either

Aug. 22

Dissension Between the Allies.

Aug. 24

Aug. 15

Aug. 28 in Newport or in Boston. But d'Estaing would not yield, and sailed away. ${ }^{2}$

Bad blood was thus stirred up between the allies at the very start. Washington, with his usual calmness and good judgment, tried to restore good feeling; and Greene and Lafayette ably seconded his efforts. But Sullivan was so angry that he was most indiscreet. He not only filed a written protest with d'Estaing, but he published an order to his troops expressing the hope that America would be "able to procure with her own arms that which her allies refused to assist her in obtaining." 2 When the militia read this they made up their minds that the expedition would fail and that they might as well go home; and more than 5,000 of them went off within a few days.

When d'Estaing had gone out to meet Howe, Sullivan had decided not to delay his operations; ${ }^{3}$ and he advanced his men to within two miles of the British lines just north of Newport. During the ensuing week he prosecuted siege operations against the British redoubts and lines in the vicinity of Easton's Pond, and for several days a vigorous artillery fire was exchanged between the two lines. But when d'Estaing's fleet sailed away and the militia went home there was nothing for Sullivan to do but to extricate himself from his difficult position as best he could-and without delay. Accordingly he retreated during the night to the northern end of the island, and there took position in the lines which had

1 Mahan, 362-364.

'Sparks, V, 41, 45, $47 . \quad$ 'Sullivan's Report, Dawson, 439. 


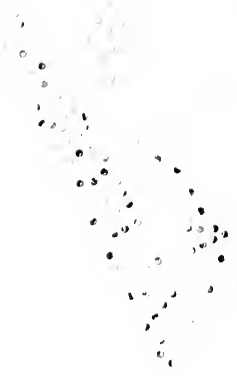

1 


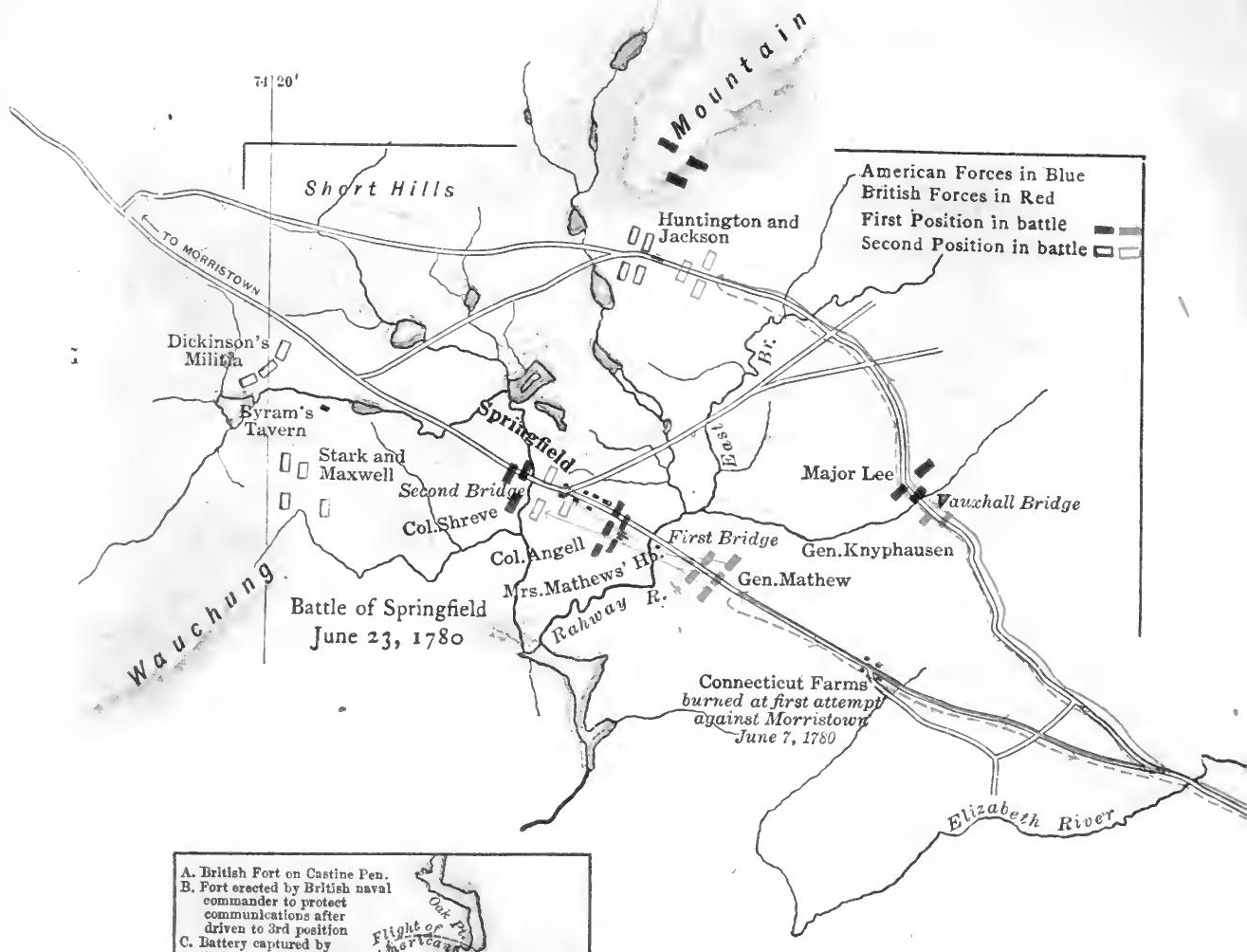

Courtesy of The Burrows Brothers Company, Publishers, Cleveland, Ohj From Avery's History of the United States and Its People 


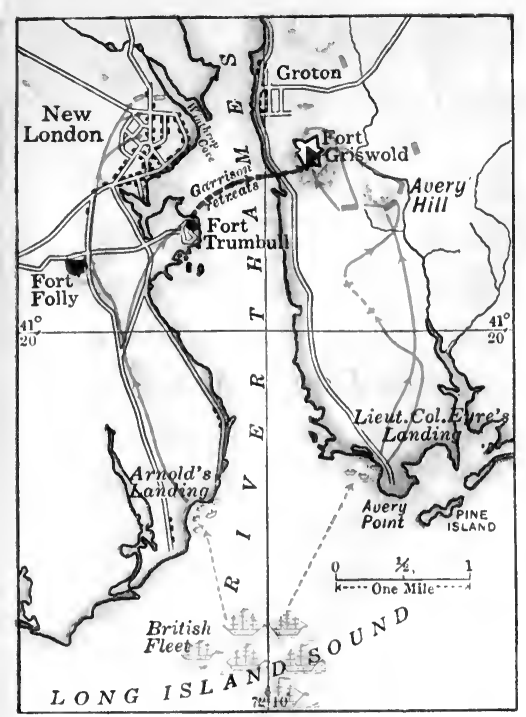

New London

Sept. 7,1781

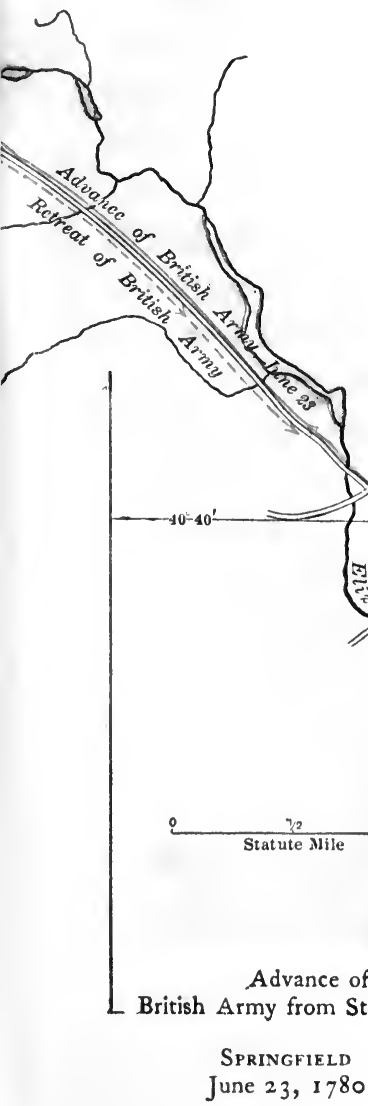

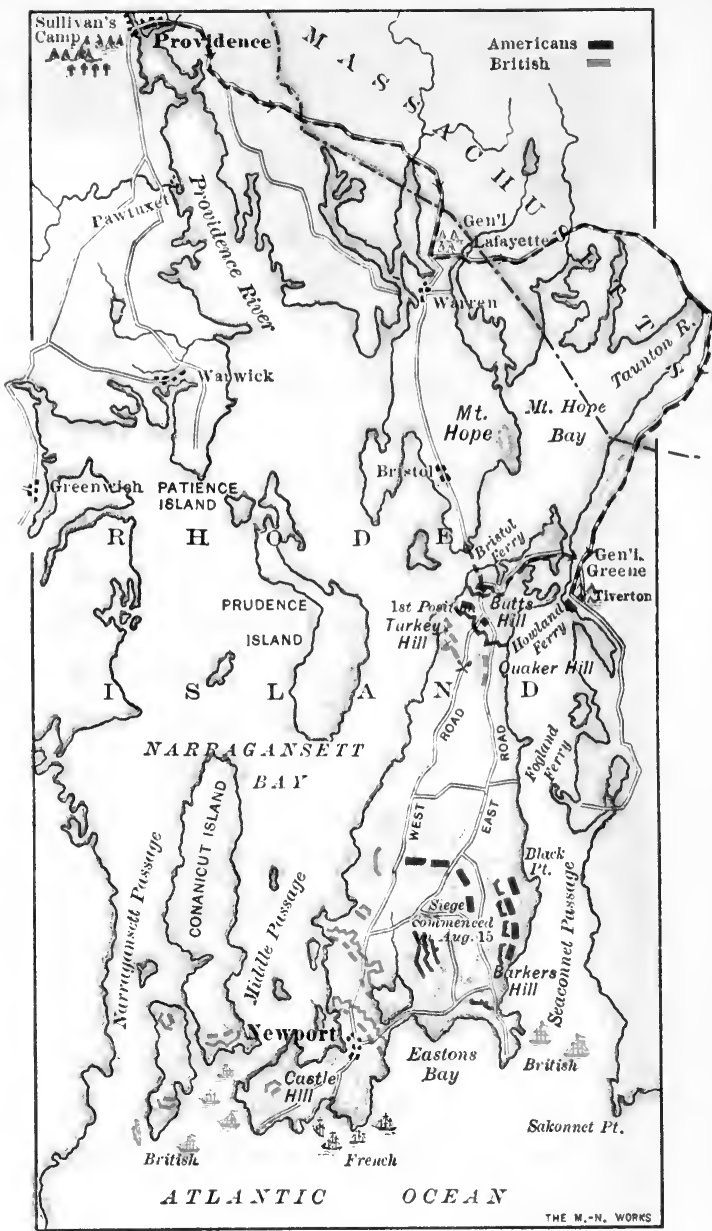

NEWPORT

Aug. 29, 1778
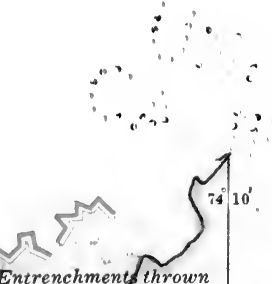

Entrenchment thrown

up by Knyphgusen after

Newark Bay
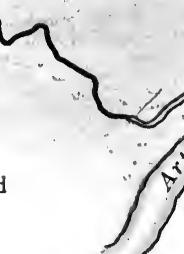

STATEN ISL AND

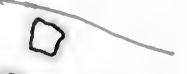

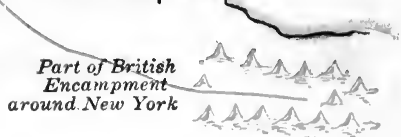




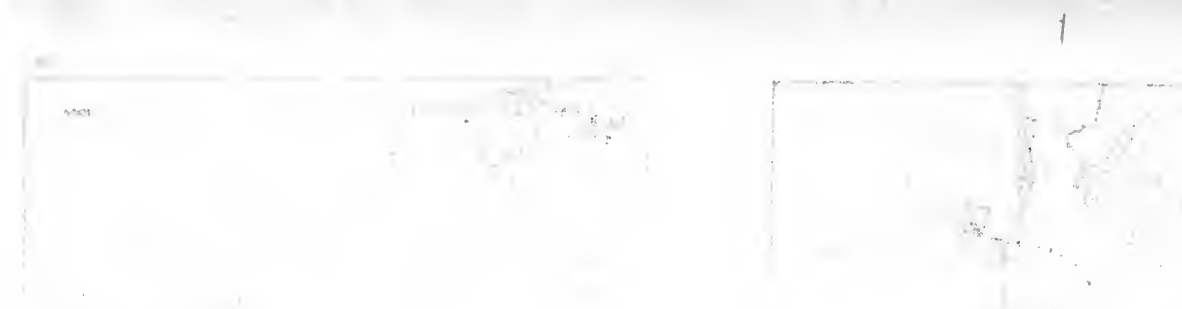


originally been fortified by the British, just south of 1778 Butt's Hill. ${ }^{1}$ At daylight Pigott moved after him in Battle of two columns, the British on the east road and the HesRhode Island sians on the west road. As soon as he came up with aug. 29 Sullivan's outposts and "light parties," skirmishing 7 А. м. began. These were driven back and then Pigott made a vigorous attack by the west road against Sullivan's right flank, which was commanded by Greene. The $\boldsymbol{\theta}$ A. м. firing continued here for several hours and the British brought their entire force into action and supported it by a flanking fire from some ships in the bay. ${ }^{2}$ But Greene had two veteran brigades-Glover's famous Marblehead fishermen and Varnum's Rhode Island regiments which had marched to Cambridge more than three years before and been in constant service ever since; in addition to these was Cornell's militia and a regiment of Rhode Island negroes commanded by Christopher Greene. They all made a good defence, and the whole force of British and Hessians could not dislodge them. During the afternoon the firing ceased. Both armies remained within a short distance of each other during the night and following day. ${ }^{3}$ Pigott sent back to Newport for aug. 30 his artillery and intended to attack again as soon as it arrived. ${ }^{4}$ But during the morning Sullivan received a letter from Washington telling him that Lord Howe had sailed from New York with reinforcements; and later in the day report was received that the British fleet had been sighted off Block Island. He decided to withdraw to the main-land, and during the night succeeded in doing so without loss, a portion of his force crossing to Bristol,

\footnotetext{
${ }^{1}$ Sullivan's Report, Dawson, $439 . \quad 2$ 'Pigott's Report, Dawson, 442.

${ }^{3}$ Sullivan's Report, Dawson, 440, 441; Sparks, Corr., II, 179-204.

' Pigott's Report, Dawson, 442, 443.
} 
1778 but the greater part to Tiverton. His losses were 30 killed, 137 wounded and 44 missing; and those of Pigott, 38 killed, 210 wounded and 12 missing. ${ }^{1}$

Aug. 31

Within a few hours of Sullivan's retreat to Tiverton, Lord Howe's fleet, carrying Sir Henry Clinton and 5,000 of his men, dropped anchor in Newport harbor. This increased the strength of the British garrison to about 11,000 men. The rest of Sullivan's militia now went home, and with his 1,200 Continentals he withdrew to Providence. Clinton made no attempt to follow him, but taking part of his men on the ships, he harried the towns along the shores of Long Island Sound. ${ }^{2}$

Nov. 4

Departure of the French Fleet.

D'Estaing finally completed the repairs of his ships at Boston and then sailed for Martinique, still keeping his 4,000 soldiers with him. ${ }^{3}$ And on the same day Clinton despatched from New York to St. Lucia the 5,000 men which he had been ordered to send there. During the winter Lafayette, after vainly endeavoring to secure Jan. 11, 1779 Washington's approval to a project for the reconquest of Canada, sailed back to France. ${ }^{4}$

The close of the year thus saw the French and English renewing their ancient strife, and the seat of war transferred to the West Indies.

The French alliance, which many thought would promptly end the war, brought at first little but distrust and recrimination. Whether the French admiral had instructions similar to those given the minister of France - to be guided by French and not entirely by American interests-is not known; but Gerard had been his guest on his flag-ship for twelve weeks, and it is probable that

${ }^{1}$ Sullivan's Report, Pigott's Report, Dawson, 438, 444.

2 Sparks, VI, 63.

${ }^{3}$ Mahan, 365. ${ }^{4}$ Sparks, VI, 190, 545-556. 
d'Estaing knew his instructions. ${ }^{1}$ To have brought peace 1778 so quickly and without an attempt to regain Canada for the French would perhaps not have accorded entirely with the French plans. Nor have we the slightest ground to complain of this. Every nation must act for its own interests first, and even exclusively. It was our good fortune that it was the interest of France to aid America in order to injure Great Britain; and its aid was of immense value in enabling America to gain what it desired. ${ }^{2}$ The military operations of the next four years at the North were of minor importance and can only be briefly summarized.

The British army occupied New York and Newport during the first winter; and Washington disposed his troops in cantonments at Middlebrook (now Bound Brook) Elizabeth, Ramapo, West Point, Fishkill and Danbury. ${ }^{3}$ They were dispersed in this fashion for the purposes of subsistence, but they were in supporting distance, and could be concentrated quickly if Clinton made any move into New Jersey, up the Hudson or into New England. The cantonments formed a semicirsle of forty miles' radius around Clinton at New York; and they guarded

1 Mahan, 359.

2 Lafayette's plan for the reconquest of Canada was submitted by him to Congress, and received the formal approval of that body October 22, 1778. Precise instructions were sent four days later to Franklin to govern his conduct as minister in France; and among these instructions were the complete plans for the invasion of Canada. At the same time Congress asked Washington for his views on the subject. In a far-sighted letter, dated November 14, 1778, he replied, opposing the project with such unanswerable arguments that it was abandoned. In this letter Washington uses these words-as true and as significant to-day as the day they were written-" "It is a maxim, founded on the universal experience of mankind, that no nation is to be trusted further than it is bound by its interest." Sparks, VI, 107, 110; Jour. Cont. Cong., 1039-1048.

${ }^{3}$ Sparks, I, 306; VI, 124, 135, 153, 158, 167. 
1778 the vital points in the Highlands of the Hudson through which communication was kept up between New England and the Middle States. The fortifications in the Highlands were meanwhile strengthened, West Point oct. being the centre of the system instead of the forts eight

Capture of Stony Point

1779

May 31

June 6

June 25

July 21 miles below which had been captured by Sir Henry Clinton. An outpost, however, was planned at Stony Point, and this was in process of fortification when Clinton attacked and captured it. At the same time he took possession of the fort at Verplanck's Point on the opposite side of the river. ${ }^{1}$

For this purpose Clinton had brought about 6,000 men up the river; ${ }^{2}$ and the possession of Stony and Verplanck's Points cut off King's Ferry, which connected the two points and which had been the usual and most convenient place for crossing the Hudson. An attack on West Point was likely to be the next move of Clinton. ${ }^{3}$

Washington therefore left Middlebrook, which had been his head-quarters for the last six months, and moved first to the Clove (near Haverstraw), then to New Windsor (Newburg) and finally to West Point, where he remained until the close of the year. Nearly 5,000 of his Continental troops had recently been sent under Sullivan to punish the Indians who had committed the massacres in the Wyoming valley of Pennsylvania during the preceding summer. ${ }^{4}$ This left him not more than about 8,000 men. This was insufficient for an attack on New York, for which there was a tempting opportunity had he had sufficient force, or had d'Estaing with his fleet and his soldiers

${ }^{1}$ Clinton's Report, Dawson, 526; Sparks, VI, 269.

${ }^{2}$ Clinton's Report, Dawson, 345.

${ }^{3}$ Sparks, VI, 164, 264, 272, 304.

'Sullivan's Indian Expedition, 1779, published by the State of New York, 1887. 


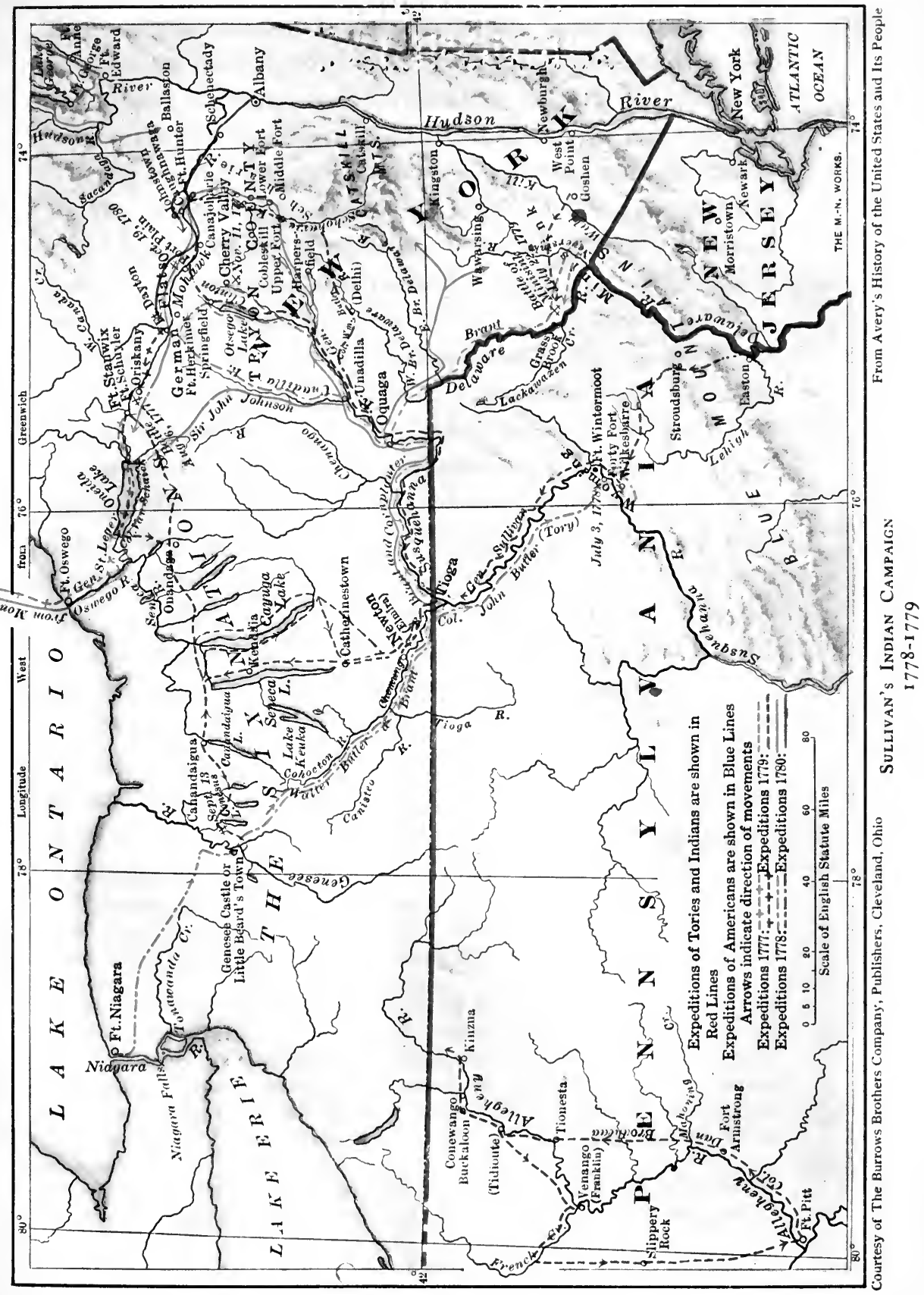




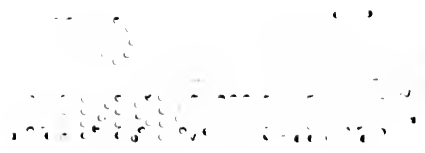

- 
been in that vicinity instead of in the West Indies. The 1779 most that Washington could attempt, therefore, was the recapture of Stony and Verplanck's Points. The former was intrusted to Wayne ${ }^{1}$ and the latter to McDougall. ${ }^{2}$ Through some misunderstanding or miscarriage of orders McDougall made no serious attempt; but Wayne carried out his part of the project in the most brilliant manner.

For this attack Washington placed under Wayne's command the light infantry of the army, about 1,200 in Recapture of number, and after reconnoitring the approaches in person he gave Wayne instructions to make the attack with unloaded muskets and to rely solely on the bayonet. As the usual hour for such enterprises was just before dawn, and on that account the watch was more strict at that hour, Washington enjoined Wayne to make the attempt about midnight. Muhlenberg's brigade of about 300 men was to follow Wayne and be in position to reinforce the attack, if necessary; or to form a rallying-point in the retreat, if the enterprise should prove unsuccessful.

Wayne began his march from Fort Montgomery at July 15 noon; and crossing the mountains in rear of Stony Point he arrived within a mile and a half of the enemy's lines at $8 \mathrm{o}^{\prime}$ clock $;^{3}$ here he formed his troops in two columns,

${ }^{1}$ Sparks, VI, 289.

${ }^{2}$ Ibid., VI, 288, 298, 299.

${ }^{3}$ Washington was generous enough to report to Congress (Sparks, VI, 298) that Wayne "improved upon the plan recommended by me [him] and executed it in a manner that does signal honor to his judgment and to his bravery."

Wayne's Order of Battle, drawn up by him on July 15 and submitted to Washington before it was read to his troops late that evening, is a model for a document of that kind-clear, definite, explicit, brief but lacking in no detail. It contained two paragraphs which showed the serious nature of the business on hand; and the understanding by his men of this seriousness was possibly one of the chief causes of the brilliant success which followed.

"If any soldier presumes to take his musket from his shoulder to fire or begin the battle until ordered by his proper officer, he shall be instantly 
July 16

Wayne's Report, July 17

each preceded by an advance guard of about 150 volunteers, and in front of these a party of 20 picked men and an officer. ${ }^{1}$ After carefully reconnoitring the ground over which the advance was to be made, Wayne placed himself at the head of the right column, and shortly after midnight both columns moved forward." Not a shot was fired on the American side. Wayne "gave the troops the most pointed orders not to fire on any account, but place their whole dependence on the bayonet, which order was literally and faithfully obeyed. Neither the deep morass, the formidable and double rows of abatis nor the strong works in front and flank could damp the ardor of the troops, who, in the face of the most tremendous and incessant fire of musketry, and from cannon loaded with grape-shot, forced their way at the point of the bayonet through every obstacle, both columns meeting in the centre of the enemy's works nearly at the same instant." Wayne was wounded at the abatis, but his men pressed on into the fort, and all of the garrison who had not been killed or wounded were taken prisoners. ${ }^{1}$

Wayne's loss was 15 killed and 83 wounded. The British lost 19 killed, 74 wounded, 58 missing and 472 prisoners-623 in all. ${ }^{2}$ The captured cannon were apput to death by the officer next to him; for the misconduct of one man is not to put the whole troops in danger or disorder, and be suffered to pass with life. ...."

After promising rewards to the first five men to enter the works, he adds: "But should there be any soldier so lost to every feeling of honor as to attempt to retreat one single foot, or to skulk in the face of danger, the officer next to him is to immediately put him to death, that he may no longer disgrace the name of a soldier or the corps or State he belongs to.

"As General Wayne is determined to share the danger of the night, so he wishes to participate in the glory of the day in common with his fellowsoldiers."

${ }^{1}$ Wayne's Report, Dawson, 525.

${ }^{2}$ Wayne's Report, Clinton's Report, Dawson, 527; Johnston, Stony Point, 206. 


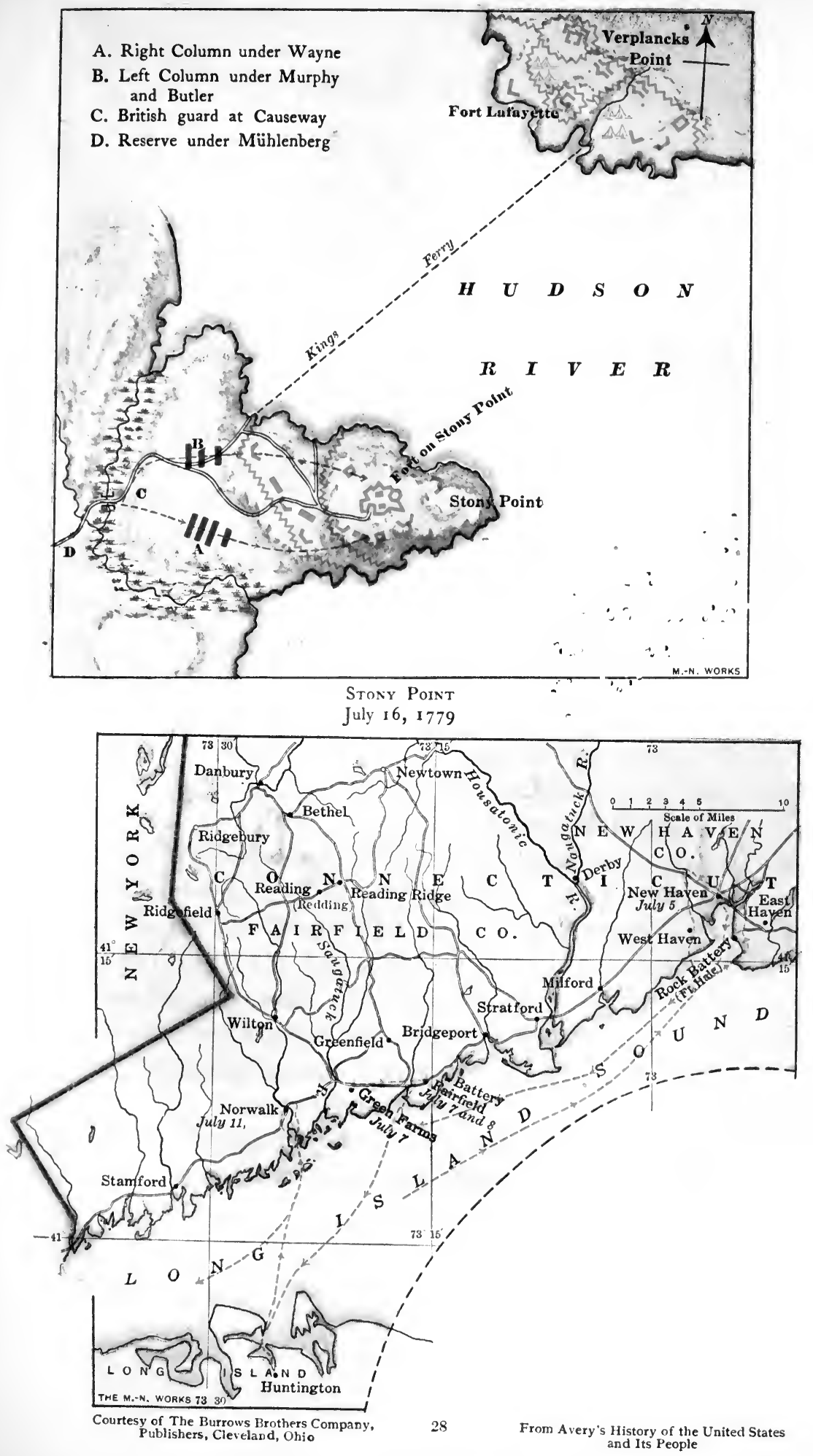

TRYON'S RAID

July $5-8$, I 779 


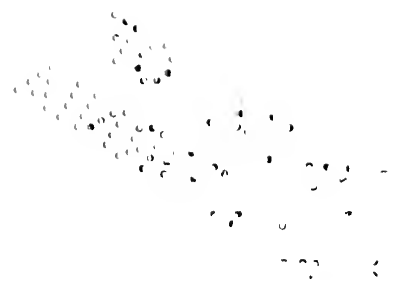


praised at $\$ 158,640$ and that sum was distributed by 1779 order of Congress ${ }^{1}$ among the officers and men of the storming party, in proportion to the pay of each; and the further sum of $\$ 1,500$ was divided among the first five men to enter the works. Congress also ordered three medals to be struck in honor of Wayne, and of Fleury and Stewart who commanded the two columns.

Sir Henry Clinton immediately brought reinforcements July 17 from New York up the river to Dobb's Ferry; and Washington made a personal examination of Stony Point. He was convinced that it could not be held by less than $1,500 \mathrm{men}{ }^{2}$. it was nearly 20 miles, following the winding roads through the mountains, from his main position at West Point. He therefore determined to evacuate the post, and the cannon and stores were removed and the Evacuation of Stony Point works destroyed during the following night, the troops July 18 retreating to West Point. Clinton brought up his whole force from Dobb's Ferry and regained possession of Stony Point the next morning. ${ }^{3}$ He retained possession July 19 of it only a short time, however. Finding that he could not draw Washington into a general engagement south of the Highlands, and not feeling any confidence in his ability to capture West Point, he soon afterward determined to transfer the war to the south and to accompany the expedition himself. ${ }^{4}$ In anticipation of this he withdrew his troops from both Verplanck's and Stony Points. In the following month Major Henry Lee, who com- oct. 21 manded the "Light Horse," requested permission to Capture of attack the British post at Paulus or Powle's Hook on Paulus Hook the Jersey shore (just behind the present site of the Jersey

\footnotetext{
1 Jour. Cont. Cong., XIV. 890-891. $\quad{ }^{2}$ Sparks, VI, 300, 301, 302.

s Clinton's Report, Dawson, 526.

${ }^{4}$ Stedman, II, 152; Sparks, I, 328; Clinton to Germain, Sparks, VI, 327.
} 
1779 City station of the Pennsylvania Railroad). Lee had been in the supporting party at Stony Point and he was keen to undertake a similar enterprise on his own account. After some hesitation ${ }^{1}$ Washington gave his consent, but stipulated that not more than 300 men should be engaged, and that no attempt should be made to hold the post. The purpose was to surprise the garrison and bring off as many prisoners as could be secured.

Aug. 18, 10.30 A. $\mathbf{~ I . ~}$

4 P. M.

Aug. 19, 3.30 A. M.

Aug. 19, 11.00 A. $\mathrm{M}$.
Lee set out from Paramus (now Ridgewood), 21 miles north-west of Paulus Hook, with part of his command and was joined by the rest at Hackensack. Through the treachery or ignorance of a guide several hours were lost during the evening and part of his men were separated from him. With the remainder, something less than 300 in number, he reached the marsh, which separated the fortified position on the Hook from the mainland, not long before dawn. The tide was rising, the day would soon break and the ammunition was ruined in wading through the marsh. Not a moment was to be lost, and the men rushed forward-as at Stony Pointwithout firing a shot. They cleared the abatis, crossed the ditch and entered the works. There was a short hand-to-hand fight, in which it is said that Lee lost only 2 killed and 3 wounded, whereas the British loss was about 50, and then the greater part of the garrison surrendered. Daylight was coming on and Lee immediately began his retreat, bringing with him 158 prisoners. On his way back he was attacked in flank by a portion of the British garrison which was on a foraging expedition near Weehawken; but Lee beat them off and arrived in safety at the Hackensack Bridge, after twenty-seven hours of continuous marching and not a little fighting. Here a ${ }^{1}$ Sparks, VI, 317, 318. 
supporting brigade under Lord Stirling received him, 1779 and the next day the entire force returned to Para- aug. 20 mus. ${ }^{1}$

Lee's exploit was justly applauded and he received the thanks of Congress ${ }^{2}$ and a gold medal. Its military importance was that which results from an "insult" to the enemy and from the encouragement it gave to our own army.

Stony Point and Paulus Hook were the only two military events of the year at the North. Clinton had, in- May 9 deed, sent a marauding expedition of 2,500 men, under Matthews, into the Chesapeake, which captured Norfolk, destroyed a number of ships at Suffolk and carried away Marauding Expeditions in Virginia and Connecticut a considerable quantity of stores, including 3,000 hogsheads of tobacco. ${ }^{3}$ Later a similar expedition, under Tryon, was sent along the Sound; it destroyed the ship- July 5 ping and set fire to the towns from New Haven to Nor- July 11 walk." These raids angered the population, but had no effect whatever on the issue of the contest.

On the other hand, about 1,000 Massachusetts militia undertook an independent expedition against Castine, Penobscot Expedition at the mouth of the Penobscot ${ }^{5}$ River in Maine, where about 800 British troops had been sent from Halifax to cover parties engaged in getting masts and spars for the British ships. The expedition was a failure, the naval Juiy 25 and military commanders quarrelled, the attack was re- Aug. 11 pulsed, a portion of the British fleet arrived from New York, the ships (24 transports and 20 armed vessels carrying 344 guns) were burned and the members of the expedition made their way home through the wilder-

${ }^{1}$ Lee's Report, Dawson, 549-552.

2 Jour. Cont. Cong., XV, 1100. ${ }^{3}$ Sparks, VI, 261, 262.

1 Tryon's Report, Dawson, 514; Sparks, VI, 285, 293.

'Sparks, VI, 307, 350; Stedman, II, 147, 151. 
1779 ness, in small groups amidst terrible hardships, during the autumn. ${ }^{1}$

This expedition was undertaken without consulting Washington, ${ }^{2}$ and is an example of that lack of central control which prevented the successful application of our military resources during the Revolution.

Dec. 7

Winter Cantonments for 1779-80

March 9

As winter came on Washington moved his head-quarters to Morristown. Sullivan's force had returned from the Indian campaign, but it was necessary to send a considerable reinforcement to the South. His little army was disposed in cantonments-much as in the preceding winter-at Morristown, in northern New Jersey, in the Highlands and in Connecticut. ${ }^{3}$ It was a winter of extreme severity, North River and a part of New York Bay being closed with ice strong enough to bear artillery. ${ }^{4}$ The sufferings of the men for lack of food and clothing were but little inferior to those at Valley Forge two years before; and it soon became necessary to resort to impressment in order to obtain food. The ever-present difficulty of obtaining recruits gave Washington the greatest anxiety, and in several of his letters he expressed the opinion that the prospect of final success was never so discouraging as at that time. Congress had consolidated ${ }^{5}$ the 104 battalions (16 Continental and 88 State "lines") into 80 battalions. The return of October showed a paper strength of 27,099 , of whom 14,998 were enlisted for the war and the others for various periods which would expire during the coming spring and summer. Washington urged an annual draft to fill up the battalions, the payment of a Continental bounty to such of the

\footnotetext{
${ }^{1}$ Thacher's Military Journal, 170; Stedman, II, 152.

${ }^{2}$ Sparks, VI, 350.

${ }^{4}$ Kapp, Kalb, 183.

3 Ibid., 408, 411, 420, 438.

s Jour. Cont. Cong., XIII, 298.
} 
drafted men as would enlist for the period of the war, 1779 and the abolition of State, county and town bounties. ${ }^{1}$ The States and towns, however, continued to exercise their own judgment about bounties, and there was much dissatisfaction among the men who three years before had enlisted for the war. The recruiting was never thoroughly organized and systematized; but a certain number of recruits was obtained by Washington's incessant appeals.

On the British side, Newport was abandoned, and the only post retained was New York. Cornwallis arrived Evacuation of Newport, with reinforcements, and these, added to the troops brought from Newport, carried the garrison of New York Dec. 1 to 28,756 . Of these 13,848 were British regulars, 10,836 were Hessians and 4,072 were Provincials. Washington had only 10,400 effective in all his cantonments; ${ }^{2}$ but Clinton did not feel strong enough to attack him. He preferred the plan of sending a large part of his force to the South.

Some months after Clinton had gone to the South, Knyphausen, who was left in command at New York, offensive determined on an offensive movement in New Jersey. ${ }^{3}$ Novem Jent in He had heard that two regiments at Morristown had mutinied because they had received neither food, clothing nor pay, and that the population of New Jersey were disaffected to the American cause. He thought that if the British troops appeared in New Jersey the people, the militia and possibly the mutinous regiments would rally to their support. He therefore took two brigades, Matthews' and Stirling's, with about 5,000 men, crossed the Kills from Staten Island to Elizabeth and marched

${ }^{1}$ Sparks, VI, 402, 403.

${ }^{2}$ Ibid., V, 543; VII, 6.

${ }^{3}$ Stedman, II, 240, 241; Sparks, VII, 76. 
toward Morristown. But he was quickly undeceived as June 7 to the temper of the inhabitants. They fired upon his troops from their houses and from the woods; Stirling was fatally wounded; the militia gathered quickly in front of him, and when after a march of eight miles he reached the village of Springfield, he found one of the regiments which had mutinied drawn up in line to oppose him. Only a few shots were fired, and then the British column began a retreat, which seems to have been unnecessarily precipitate, to Elizabeth. They would have crossed to Staten Island, but the low tide prevented their getting their cavalry to the bridge of boats which they had built across the Kills where it joins Newark Bay. They therefore stopped on the Jersey shore, and threw up intrenchments, in the nature of a bridge head, for their protection. ${ }^{1}$

A few days later Clinton returned to New York from South Carolina, and he determined to do something to redeem this fiasco. He therefore put some of his troops on transports and made a feint of moving up the Hudson. Washington promptly started toward Ramapo and the Clove with a part of his force, leaving Greene in command at Morristown. Greene with about 1,000 Continentals and the Jersey militia under Dickinson took position behind the stream at Springfield, about 10 miles in advance of Morristown. ${ }^{2}$

Battle of Springfield, June 23
Knyphausen left Elizabeth early in the morning with about 5,000 infantry, a considerable body of cavalry and 18 pieces of artillery. Marching rapidly, he soon reached the Elizabeth River, about 3 miles east of Springfield, and there divided his force into two columns; sending

${ }^{1}$ Stedman, II, 240, 241; Sparks, VII, 76.

${ }^{2}$ Ibid., II, 243, 244; ibid., VII, 85, 87, 506-508. 
Matthews forward on the road to Springfield, while he 1780 himself took the Vauxhall road on the right, intending to turn Greene's left flank. Greene sent Henry Lee with his cavalry and a regiment of infantry to defend the Vauxhall bridge, and posted the rest of his Continentals at the two bridges in front of Springfield. The militia were placed on the flanks. While these troops were far inferior in strength to the British force, they made so spirited a defence at the bridges that they delayed the advance of Knyphausen until late in the afternoon, and gave Greene time to withdraw his force to a strong position in front of Short Hills, where the Vauxhall and Springfield roads came together. Here he awaited an attack; and a brigade, sent back by Washington as soon as he heard of the fight, was momentarily expected. But instead of attacking, the British set fire to the houses in Springfield and late in the afternoon began a hasty retreat-so rapid that Stark's brigade, which was sent in pursuit, was unable to overtake them.

Greene's loss was 13 killed, 62 wounded and 9 missing. The loss of the British was supposed to be somewhat larger, but was never accurately known.

Knyphausen remained at his bridge head near Elizabeth until midnight and then crossed over to Staten Island, taking up his bridge of boats at daylight. ${ }^{1}$ The June 24 British troops never again attempted any serious operations in New Jersey. ${ }^{2}$

Washington did not return to Morristown. He thought that Clinton would attack the forts in the Highlands, and he moved his army to the northern part of New Jersey; and moved his own head-quarters, in succession,

${ }^{1}$ Sparks, VII, 506-508; Dawson, 596-600.

2 Stedman, II, 244. 
July 26

Washington to President of Congress, April 14, 1779

Nov. 24, 1779

Arnold in Command at West Point

Aug. 4

Arnold's Treason

Feb. 3, 1779

May 1, 1779

Jan. 20, 1780

to Ramapo, to Peekskill and to West Point. Greene, worn out with the vexatious relations with Congress in his uncongenial and thankless task as quartermastergeneral, finally resigned that post ${ }^{1}$ and resumed his duties in the line, being now second in command to Washington. Washington, conscious of his own strength and rectitude, waived all consideration of the innuendoes and unjust criticism of him which Gates was constantly sending to his friends in Congress. He had offered Gates the command of Sullivan's expedition against the Indians, which Gates curtly declined. As the command in the Highlands seemed now the most important station in the army, Washington offered this to Gates; he again declined, and obtained leave to retire to his estate in Virginia. Arnold then applied for the command at West Point and his application was supported by some members of Congress., After considering the application for several months, Washington granted it, and Arnold took command. ${ }^{3}$

This application was made with treasonable intent, for, as was afterward learned, Arnold had been in correspondence with Clinton under an assumed name for nearly eighteen months. While in command at Philadelphia, he lived beyond his means and got into debt; ${ }^{4}$ he also gave offence to the Council of Pennsylvania and they preferred charges against him. Washington promptly ordered a court-martial, but the council were slow in producing their witnesses, and the trial dragged through the year. It was finally concluded, and the court found him censurable on two of the charges and sentenced him to a

${ }^{1}$ Sparks, VII, 91, 131, 150, 304, 512, 515.

${ }^{2}$ Ibid., VI, 188, 189, 214-223, 409.

'Ibid., VII, 95, 139, 140, 265, 521.

‘ Arnold, 239. 


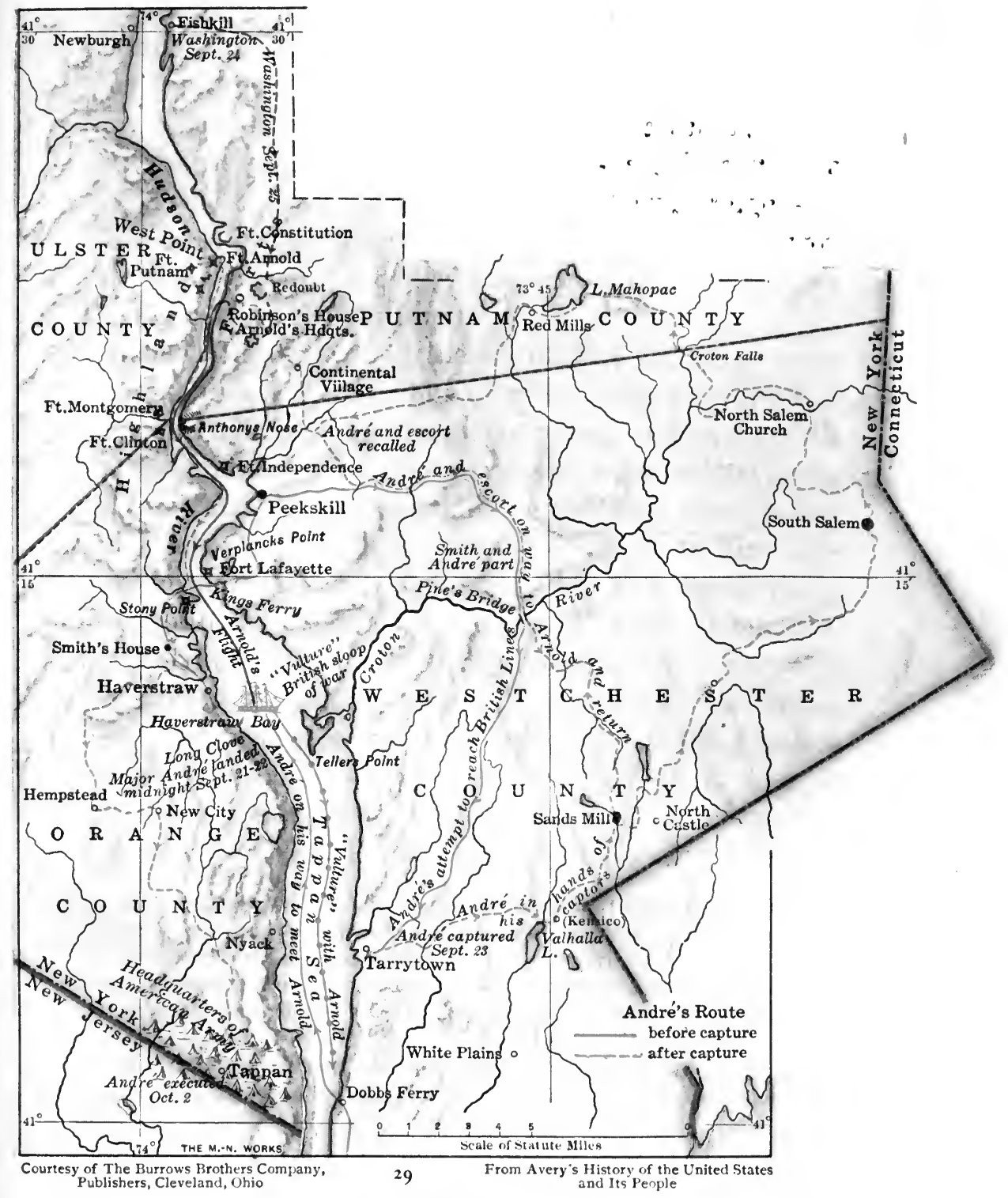

ARNold's TrEason

ANdré's Capture

Sept. 20-25, 1780 


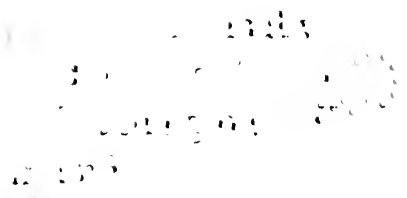


reprimand. ${ }^{1}$ While he was a brave and skilful soldier, 1780 his mind was ill-balanced; and brooding over his grievances and the slights which he fancied had been put upon him ever since the capture of Ticonderoga in 1775, he thought he would duplicate the parts which had been played in the past by Monck and by Marlborough ${ }^{2}$ - to their great profit-and would deliver the American army into the hands of the British and restore the allegiance of the Colonies to the British crown.

When Clinton learned the identity of his anonymous correspondent he turned him over to André, his adjutantgeneral. The correspondence continued, and at Arnold's Meeting of Arnold and André, Sept. 21 request and under his passport André went up the river, and met Arnold late at night, on the west shore a few miles below Stony Point. Arnold delivered to him various documents, some of them in his own handwriting -a detailed statement of the troops, 3,086 in number, stationed at various posts in the Highlands; a complete description of the forts in the Highlands and the armament and ordnance stores at each; the standing orders to the garrison as to what they should do in case of attack; and a copy of the proceedings of the council of war held at West Point a short time before. ${ }^{3}$ What

1 The language which Washington used in this reprimand is classic. "Our profession is the chastest of all; even the shadow of a fault tarnishes the lustre of our finest achievements. ... I reprimand you for having forgotten that in proportion as you have rendered yourself formidable to our enemies, you shouid have been guarded and temperate in your deportment toward your fellow-citizens. Exhibit anew those noble qualities which have placed you on the list of our most valued commanders. I will myself furnish you, so far as it may be in my power, with opportunities of regaining the esteem of your country." (Arnold, 261.)

${ }^{2}$ Monck delivered the Roundhead army to Charles II; Marlborough deserted during the night from James II to William of Orange, and aided in establishing William on the throne. See Wolseley's Marlborough, where the question of Marlborough's honor is discussed at length.

${ }^{3}$ All the essential letters are given in Sparks, VII, 520-552. 
1780 plans were verbally discussed at this midnight meeting is not a matter of record; but it was universally believed, and doubtless correctly, that they included the details of an attack by Clinton and a surrender by Arnold; and that this would take place either during the next two days or later, during an expected movement of Washington against New York, concerning which Washington was at that moment in conference with Rochambeau at Hartford.

Sept. 22

Capture of André,

Sept. 23

Sept. 25

The next morning Arnold returned to his head-quarters at the Robinson house, opposite West Point, and André started to return to New York. He was captured near Tarrytown with the above-mentioned documents in his boots. The officer to whom André was brought sent word of the capture to Arnold, and despatched the documents by messenger to meet Washington on the road back from Hartford. Arnold received the intelligence while at breakfast. He immediately left the house and escaped in his barge, which rowed him down the river below Verplanck's Point, where he arrived safely within the British lines.

Washington arrived at the Robinson house, on his return from Hartford, an hour after Arnold had left. He crossed to West Point and inspected the works, and returned to the Robinson house about noon. There the messenger, who had missed Washington on the road, arrived with the documents and a letter from André. Hamilton was at once sent off in the hope of capturing Arnold, but the latter had so many hours the start that pursuit was fruitless. Simultaneously orders were sent to Greene, who had been left in command of the army at Tappan during Washington's absence, to march the left wing to King's Ferry so as to be in position to dispute any attempt of Clinton to come up the river. ${ }^{1}$

${ }^{1}$ Sparks, VII, 520-552; also VII, 205, 212, 214-221, 235, 241, 256. 
The unfortunate André ${ }^{1}$ was first brought to West 1780

Point and then to Tappan. A board of fourteen general officers, with Greene as president, and including Stirling, Lafayette, Steuben, James Clinton, Knox, Glover and Trial of Andre, Sept. 26 Stark, was convened to try André. The board found sept. 29 that "under a feigned name and in a disguised habit he passed our works," . . . that he was captured "in a disguised habit," while on his way to New York, and "when taken he had in his possession several papers which contained intelligence for the enemy." The board was therefore of opinion that he "ought to be considered a spy from the enemy, and that agreeably to the laws and usage of nations, it is their opinion he ought to suffer death." Washington approved the sentence, and André was hanged. Appeals were made by Arnold and ClinDeath of André, Oct. 2, ton, ${ }^{1}$ and the latter sent up the tory chief-justice to argue that André was not a spy; it is said that Arnold offered to Clinton to take André's place, but Clinton declined to allow it; and André himself, in a touching letter, appealed for the privilege of being shot instead of dying "on a gibbet." ${ }^{1}$ But there was too much at stake; the proof of his being a spy was incontrovertible, and Washington-deeply affected as he was-was inflexible that he should die the death of a spy.

Forty years later his body was disinterred, carried to England and buried in Westminster Abbey near a monument which had already been erected to his memory, in the company of England's greatest men. The author of his misfortunes, the man who tempted him, received for Subsequent Career of his treason a commission as brigadier-general in the British army, and fought against his former comrades during the campaign in Virginia. He was then brought

${ }^{1}$ Arnold, 307, 311, 335, 343, 348; Sparks, VII, 534, 540, 542, 543. 
1780

New London Massacre, Sept. 7,1781

north and led an expedition of tories and Hessians against New London, not many miles from his birthplace. It was the last engagement of the war at the North. He captured Forts Trumbull and Griswold, burned the town and massacred the garrison. Soon after he was sent to England, and received $£ 6,315$ in money for himself, a pension of $£ 500$ a year for his wife and $£ 100$ a year for each of her children. Subsequently the King gave him a grant of 13,400 acres of land in upper Canada. He remained in the British army until his death twenty years later; but the British officers despised him; he fought a duel in resentment of their insults, got into debt, lost his fortune and died in poverty. ${ }^{1}$ It is said that he died in the uniform of an American major-general, which he had on at the time he escaped from the Robinson house and which he had always preserved.

The actual damage which he succeeded in doing to the American cause was slight; but it was not for lack of intention. His name has been a synonym for infamy during 130 years, and it seems probable that it will so continue so long as history is written.

Meanwhile, what of the French alliance? What were the French ships and soldiers doing during the two years and more which had elapsed since the signing of the treaty? Feb. 6, 1778 The answer, in brief, is that they were fighting the common enemy, England, in the West Indies. They thus created a diversion by causing British ships and soldiers to be sent from New York to St. Lucia and elsewhere; and to this extent they aided the American cause. But while the French were primarily concerned with French interests, Washington was keenly alive to American interests. He thought that as much harm could be done

${ }^{1}$ Arnold, 348, 363, 378, 389, 393, 395. 
to England, and more benefit conferred on America, if 1780 the French would concentrate their strength at New York. If they could command the sea and land only a few of their troops, he pledged himself to "bring 25,000 effective men into the field"; and with these he felt confident that he could capture the city and its garrison and put an end to the war. All through the year $\mathbf{1 7 7 9}$ he tried to bring this about. He had conferences with Gerard, sept. 16 the French minister, and his successor, Luzerne. He oct. 4 wrote to d'Estaing; he called on the governors of the oct. 2 nearest States for 12,000 militia and they began to as- sept.13 semble; he stationed Henry Lee, and later Duportail oct. 10 and Hamilton, on the Jersey coast with letters to be handed to d'Estaing as soon as he reached the Delaware capes. ${ }^{1}$

But d'Estaing never came. Although he had written that he would be on the coast of Carolina in May, he reMovements of d'Estaing mained in the West Indies to capture St. Vincent and June 16 Grenada. Then he went to San Domingo and thence July 4 to Georgia. But instead of making short work of the British there as he had anticipated, and then proceeding to the Delaware and New York, he became involved oct. 9 in a siege at Savannah, and finally in an assault, in which he was repulsed and wounded. Then he sailed away to oct. 20 France. ${ }^{2}$ Washington heard of this at the close of the year; he dismissed the militia and put his Continentals Nov. 20 into cantonments as previously stated. It was a bitter disappointment.

A few months later Lafayette rejoined Washington at May 10. 1780 Morristown, after an absence of sixteen months in France. While the responsible French ministers had an eye single

${ }^{1}$ Sparks, VI, 61, 62, 237, 368, 371, 373, 378, 409, 540.

'Mahan, 367, 376; Sparks, VI, 320, 361, 368, 409. 
Arrival of Second French Expedition May 2 July 10

July 15

to the interests of France as they understood them, and used their ships and their men to protect their interests in the West Indies rather than in an attack upon New York-this enthusiastic young nobleman cared nothing about the West Indies, but was wholly and disinterestedly devoted to America, and to Washington personally. It was due chiefly to his persistent and persuasive appeals during his absence in France that the King was induced to send a new and larger expedition to America, and to give explicit instructions to its commander that he was to act under Washington's orders. ${ }^{1}$

The expedition consisted of 7 ships of the line under de Ternay convoying transports carrying 6 full regiments (6,000 officers and men) under Rochambeau. It sailed from Brest and landed at Newport. It was to be followed by a second expedition of 4 regiments; but this was blockaded in Brest by a British squadron and never arrived. ${ }^{2}$

Lafayette had brought to Washington full information in regard to the French expedition and copies of the instructions; which were that the French troops should act as a unit, under Washington's orders, should "cooperate in the most effectual manner" and that the plan of campaign should be left to Washington. Before Rochambeau arrived Washington had prepared his plan -which was an attack on New York-had completed his own arrangements for supplies and for calling out a large body of militia. He sent Lafayette to confer with Rochambeau, carrying with him detailed instructions, both written and verbal, in regard to the movement against New York. ${ }^{3}$ This was to begin immediately, and the

${ }^{1}$ Sparks, VI, 368, 497, 545-556; VII, 511.

${ }^{2}$ Ibid., VII, 171, 176, 520; Mahan, 382, 394.

3 Ibid., VII, 142, 171, 496-498, 510. 
allied troops were to meet just north of the Harlem River about August 5 .

But this plan was upset by the British naval commanders. It was a fundamental part of the plan that the French should have a naval superiority. ${ }^{1}$ They had this when de Ternay arrived. But within ten days they lost it. De Ternay had been followed across the Atlantic July 13 by six British ships under Admiral Graves, who arrived at New York a few days after de Ternay reached Newport. ${ }^{2}$ This restored the British superiority on the sea; and the combined fleet under Admiral Arbuthnot promptly, sailed for Newport and anchored off Point July 21 Judith.

Clinton followed this with 6,000 troops which left New York and proceeded down the Sound with the intention of attacking Newport. But Washington instantly met this move by crossing his army from New Jersey at Dobb's Ferry, and marching down toward Kingsbridge to attack New York. Clinton thereupon returned to July 31 New York, the British fleet, however, still remaining off Point Judith, blockading the French and intercepting or turning back their despatch-boats. News of Clinton's movement reached Rochambeau and he immediately called upon Heath, who commanded in New England, for militia to aid in his defence. Several thousand turned out quickly and went to his assistance on Rhode Island. ${ }^{3}$

Within a month after its arrival, therefore, the French expedition of 1780, far from aiding Washington in any offensive movements, found itself cooped up in New-

French Army and Navy Blockaded in Newport

1 "A naval superiority being essential to every enterprise in these States," Washington to Guicken. (Sparks, VII, 196.) "A decisive naval superiority is to be considered as a fundamental principle," Washington to Lafayette. (Sparks, VII, 509.)

${ }^{2}$ Sparks, VII, 113, 127, $169 . \quad$ ' Ibid., VII, 113, 127, 131, 138. 
$\mathbf{1 7 8 0}$ port and relying on the New England militia for its protection.

After Clinton had returned to New York the militia were gradually sent home; but the British fleet remained

Sept. 21

The Revclution Nearly Exhausted

March 18 on the blockade. Washington went to Hartford and discussed the situation with de Ternay and Rochambeau. All were agreed that the French army could not leave its fleet until sufficient ships should arrive to establish their naval superiority; and while there was a large French fleet in the West Indies at all times during the years 1780 and 1781, yet for various reasons no part of it came to America until late in the summer of the latter year. ${ }^{1}$

Nothing, therefore, could be done. The French army remained inactive at Newport for eleven months after its arrival. ${ }^{2}$

During this time the Revolution came near to expiring from sheer exhaustion. Its credit was exhausted; paper money had been issued by Congress to the extent of $\$ 241,000,000$ and by the States to $\$ 209,000,000$; and no provision had been made for its redemption. ${ }^{3}$ Congress attempted to fix its value at 40 to 1 in specie, but the market rate was soon 1,000 to $1,{ }^{4}$ and finally it had no value whatever. ${ }^{5}$ Having neither money nor credit, Congress then attempted to collect supplies from the States in kind. The response was such as each State saw fit to make. ${ }^{\circ}$ What was furnished, together with

${ }^{1}$ Sparks, VII, 195, 203, 207, 509.

' Lossing, I, 316-321.

${ }^{5}$ Fiske, Amer. Rev., II, 197, 198.

"Washington wrote to Congress (April 3, 1780) that this system "has proved in its operation pernicious beyond description"; and to Joseph Jones in Congress (May 31, 1780): "One State will comply with a requisition of Congress; another neglects to do it; a third executes it by halves; and all differ either in the manner, the matter or so much in point of time that we are always working uphill." (Sparks, VII, 13, 67.) 
what was obtained by impressment was barely enough to 1780 keep the troops from starving. In clothing there was a similar destitution; and in powder the supplies were so low that Washington endeavored through Lafayette to negotiate a loan $^{1}$ from the French of 30,000 pounds of this indispensable article. As to recruiting, matters were in the same unsatisfactory condition that they had been in for the last five years. The 104 battalions authorized in 1776 had been consolidated into 80 battalions in 1779, March 9, 1779 and were now further consolidated into 50 regiments of oct. 3, 1780 infantry, with 4 regiments of cavalry, 4 of artillery and 1 of artificers. ${ }^{2}$ Their organization was to be substantially that which had been prepared by Steuben and approved by Congress in 1778; enlistments were to be for the war; but if the States could not fill up their quota with recruits for the war, then they were recommended to fill them up with recruits enlisted for one year. ${ }^{3}$

Resolutions were passed at intervals of a few months, Nay 20 sometimes "requiring" and at others "requesting" or sept. 21 "recommending" the States to fill up their quota." If oct. 3 this had been done the strength of the army (including Dec. 22 officers) would have been 35,850 infantry, 2,720 artillery Ineffective and 2,020 cavalry. ${ }^{5}$ But it was not done. The regi- Plans for ments seldom had more than one-third of their authorized strength. The response, by States or individuals, to the resolutions of Congress was feeble. The war had been in progress nearly six years, and ardor for enlistment was greatly diminished. The French alliance was in itself a detriment to recruiting. The average man could

${ }^{1}$ Sparks, VII, 118.

${ }^{2}$ Jour. Cong., III, 223, 432, 532, 538.

' On Washington's recommendation this was modified, October 21, so as to provide "that the whole of the troops be enlisted for the war"; but the States continued to enlist recruits for one year. (Jour. Cong., III, 538.)

${ }^{4}$ Jour. Cong., III, 458, 521, 532, 557.

'Ibid., III, 538. 
1781 not comprehend the importance of the command of the sea, and he could not understand why more soldiers were required when 6,000 well-trained and well-equipped French infantry were doing nothing at Newport. Finally the sufferings and destitution of the half-starved and halfnaked men who had enlisted were not such as to tempt others to share their fate. This winter the troops were cantoned, as before, from Morristown, through the Highlands, to Connecticut. ${ }^{1}$ It was the fourth winter, counting from Valley Forge, in which each time the suffering had been almost beyond endurance.

At last the troops resolved that they would stand it no longer, and a mutiny broke out. The six Pennsylvania

Jan. 1, 9 P. M.

Mutiny of the Pennsylvania Line regiments, forming Wayne's division, stationed at Morristown, began the new year by parading under arms, and under command of their sergeants marched off toward Philadelphia. In attempting to control them one officer was killed and several were wounded. Wayne, who not only at Stony Point but at Monmouth and elsewhere had shown the most intrepid courage, rushed in among his men and drew his pistol; but they merely placed their bayonets against his breast and would have killed him if he had persisted. They marched off; and the next day he followed and overtook them at Princeton. They stated their grievances-no pay for the last twelve months, insufficient food and clothing, expiration of service (on the ground that they had enlisted for three years or the war, and were held for the war after the three years had expired). Wayne was powerless to give any relief in these matters, and the men continued their march to Trenton. Three emissaries, despatched by Clinton as soon as he heard of the trouble, attempted 
to induce them to go over to the enemy. But they indignantly turned these over to Wayne, and after a sum- Jan. 10 mary trial assisted in hanging them. At Trenton they were met by a committee of Congress, by the President of Pennsylvania and by a force of 1,000 men under St. Clair, sent by Washington to oppose their crossing the Delaware. They stated their case, and the committee promised them prompt payment of portion of their pay, immediate supply of certain specified articles of clothing and discharge forthwith of all those who had not enlisted for the entire war-the term of enlistment to be established by each man's oath. They were practically all discharged, and their arms and ammunition were sent to Philadelphia. They were then asked to re-enlist for the war, receiving the bounties then paid to recruits; and almost all of them did so within ninety days. ${ }^{1}$ They were soon sent to Virginia and rendered good service in the Southern campaign.

The success of this mutiny led to another-the three regiments of New Jersey, stationed at Pompton. They Jan. 20 similarly marched off one evening, under their sergeants, for Trenton. But Washington, who had by this time Mutiny of the New Jersey satisfied himself that he could rely upon the main body of his troops, determined to handle this affair in a different manner. He placed a detachment of New England troops under command of Major-General Robert Howe, of North Carolina, and directed him "to compel the mutineers to unconditional submission," and "to grant no terms while they are with arms in their hands in a state of resistance." Howe carried out these instructions to the letter. He surrounded the camp of the mutineers at Ringwood, disarmed them, selected one ringleader from ${ }^{1}$ Sparks, VII, 350, 359, 364, 387, 436. 
1781 each regiment, tried them by summary court and hanged

Jan. 15

Laurens's

Mission to

France

Feb. 13

Aug. 25 them on the spot. The others promptly submitted and returned to duty. ${ }^{1}$

Washington had repressed these outbreaks with a stern hand, but at the same time he wrote to the governors of States calling upon them to take steps to redress the well-founded grievances of the men in the matter of pay, clothing and food, ${ }^{2}$ with the result that their conditions were to some extent improved and a few dollars in real money were paid to them.

He realized, however, that the country was nearly at the end of its resources, or, as he expressed it (in the letter to Laurens), "the people are discontented; but it is with the feeble and oppressive mode of conducting the war, not with the war itself." 3

In order to bring the war to a close it was essential to raise some hard money. For this purpose LieutenantColonel John Laurens, of South Carolina, one of his aides, was selected; and Congress appointed him a special minister to France. ${ }^{4}$ Washington gave Laurens a letter of instructions, written in that clear, impressive and forcible style of which he was so complete a master. In this he set forth the actual situation in America, the cause of her financial difficulties, the great natural resources which would enable her to repay a loan and the imperative need of two things-a loan of money and "a constant naval superiority on these coasts." With this letter ${ }^{5}$ Laurens sailed from Boston; he landed there on his return six months later. Vergennes was of opinion

${ }^{1}$ Sparks, VII, 380, 386, 560-566.

'Sparks, VII, 373.

${ }^{2}$ Ibid., 381.

${ }^{4}$ Ibid., 368.

${ }^{5}$ The original, in Washington's handwriting, is in the Archives of the Foreign Office in Paris. A complete copy is printed in Sparks, VII, 368-373. 
that the manner in which he pressed his case savored more of the camp than of diplomacy. ${ }^{1}$ However that might be, he induced the French ministers to make a loan of $6,000,000$ francs; ${ }^{2}$ he converted some of this promptly into arms, ammunition and clothing, all of which he brought back with him, together with 2,500,000 francs in hard cash. ${ }^{3}$ His representations and Washington's letter also led to the sending of the French fleet from the West Indies to Yorktown, thereby establishing the French naval superiority, and enabling Washington to carry out his long-deferred plans for making the French alliance really effective.

${ }^{1}$ Sparks, VII, 526; Diplomatic Correspondence of the Revolution, IX, 211.

${ }^{2}$ Vergennes stated that the amount which the French King had advanced to America, to the close of 1781 , was $20,000,000$ francs, exclusive of the cost of maintaining the French army and navy in America. (Sparks, VIII, 526.)

${ }^{3}$ The financial assistance of France was far more effective than its military co-operation. In the list of Combattants Français de la Guerre Americaine, furnished by the French Government, and published by the United States Senate in 1905, there are more than 47,000 names-the officers and men of 62 naval vessels and 13 regiments, who at one time or another landed on our shores or cruised in our waters. But like the American militia they came and went at their own will; the greatest number ashore at any one time was 8,400; they took part in two battles only, Savannah and Yorktown; their battle losses were 637 at Savannah and 186 at Yorktown. In a military sense they were more than offset by the German troops who fought with Great Britain. These numbered 29,867, of whom only 17,313 returned. Their effective strength from 1777 to 1782 was never less than 12,000 . They were always subject to the orders of the British general, and, hirelings though they were, they fought well; they were in 9 principal battles and 11 minor engagements, and their killed and wounded numbered 2,200. (Lowell, 301; Sparks, V, 542-545.) 


\section{CHAPTER VI}

\section{CONQUEST OF THE SOUTH}

Aт the time of the Revolution, Boston was about as far removed from Savannah as it now is from Manila. By sea the distance was 1,100 miles; and the time, depending on wind and weather, was from 8 to 30 days. The British controlled the sea and that avenue of communication was not open to the Americans. By land, the roads were so bad that troops could not make the march in less than 60 days, and a courier riding "express" consumed fully 20 days. In fact the letters exchanged between Washington and Greene, after the latter had assumed command in the South, were usually 30 days old when they reached their destination.

The Thirteen Colonies were divided, by topographical conditions as well as by political affiliations, into three groups, whose interests were by no means identical. The dividing lines were the Hudson River and the Potomac River and Chesapeake Bay. The four New England Colonies had a population of less than 750,000, and were engaged in agriculture and ocean commerce, with the beginnings of some struggling manufactures; the five Middle Colonies had a population of not quite $1,000,000$; they were almost wholly agricultural and furnished the food supplies; the four Southern Colonies, with a population of more than $1,000,000,{ }^{1}$ were also

${ }^{1}$ Census Report on Growth of Population, 1909, p. 9. 
agricultural, but their chief product was tobacco (the 1775 cotton planting being then only just introduced and the cotton-gin being not yet invented), and the greater part of this was raised for export.

These elementary facts must be considered in order properly to understand the military events of the Revolution. The Northern and Southern Colonies were so far separated that they were not within supporting distance; and by its command of the sea ${ }^{1}$ England was able to move its troops in attack upon one or the other in one-fourth of the time that the Americans could move from one to the defence of the other. The Northern and Southern campaigns were therefore entirely distinct and separate; and each section, for the most part, relied upon itself for its defence. Moreover, the lack of identity in interest between the three groups of Colonies produced jealousies in the small body of Congress, where the vote was always by States; and these jealousies prevented the utilization of the full military resources of the country. ${ }^{2}$ While Congress did not possess any specific power to enforce its resolutions, yet in those matters where the States were in unanimous accord, the State government was quite ready to exert its sovereign power to carry these resolves into effect. But where there was only a narrow majority, each State carried them out or not as it saw fit $^{3}$ and each State was keenly alert, both in Congress and in its own legislature, to see that the effect of any measure did not give to one State an advantage over another. Against this sectionalism, which applied to

${ }^{1}$ Sparks, VII, 169, 170, 196, 337, 371; Mahan, 397-400.

2 Sparks, VII, 67, 167, 225, 298, 333, 391.

3 "One State yields obedience, and another refuses it, while a third mutilates and adopts the measure in part only, and all vary in time and manner." (Washington to Custis, Sparks, VII, 442.) 
1775 the assembling and movements of troops as well as to other matters, Washington's letters contain a series of protests, made year after year in temperate and judicious but none the less strong and forcible language. But they were all in vain.

British Plans for Dividing the Colonies

As the State of Virginia contained nearly one-fifth of the entire population, and the four Southern States about forty per cent of it, the British constantly sought to detach these States from their allegiance to the cause of the United Colonies; hoping to accomplish this, first by conquest and after conquest by conciliation. The true military principle for suppressing the Revolution was to defeat, crush and disperse Washington's army, wherever it was, and to capture or kill Washington. Had the British adhered to this principle, and successfully carried it into effect, there is slight reason to doubt that the Revolution would, at that time, have failed. But they did not adopt this principle. Their plans were always based on acquiring territory and re-establishing piecemeal the authority of the crown. Thus they took New York and held it as their base of operations; captured Philadelphia and then lost it; occupied Newport with a view to retaking Boston, but never carried out that part of the plan; tried to take Charleston and failed; sent Burgoyne on an abortive expedition down the Hudson in the hope of detaching New England from the Central States; and then abandoned all aggressive movements at the North and attempted to wear out the Revolution by petty raids into Connecticut, New Jersey and Virginia. Finally, when the war had been in progress for four years without producing any substantial results except the establishment of a base at New York, it was determined to make the South the principal theatre of operations, in 
the hope that if the North could not be subdued, at least its importance could be greatly diminished and its expansion prevented by restoring the populous Southern Colonies to British allegiance, and thus creating a barrier on the south similar to that of Canada on the north. ${ }^{1}$

The war began at the South in much the same fashion as at the North. The attack at Lexington and Patrick Henry's eloquence caused the four Southern Colonies to break out into such open resistance that three of the royal governors found it necessary to seek refuge on British ships of war, and to write home asking that regular troops be sent to their assistance. Pending the arrival of these there were conflicts with the militia. The first of these was in Virginia, at the Great Bridge over the Great Bridge, Elizabeth River, about nine miles from Norfolk. ${ }^{2}$ In this encounter the British were defeated and their com- Dec. 9 manding officer fell, pierced by fourteen bullets. The militia pursued them and took possession of Norfolk. ${ }^{2}$ Soon afterward the royal governor, from his ships, called 1776 on the town to surrender; and this being refused he bom- Jan. 1 barded it for three days, set fire to it and reduced it to Jan. 4 ashes. $^{3}$

The next clash was in North Carolina, at Moore's Bridge, over a branch of the Cape Fear River, near the Moore's Bridge, N. C. site of the present town of Fayetteville. The contestants Feb. 27 were about 1,500 tory militia, raised by the royal governor,

${ }^{1}$ There were ten principal battles at the North, with aggregate losses of a'vout $24,000 \mathrm{men}$; and eleven at the South, with losses of about 18,000. In numbers, importance and losses the battles in the South were about equal to those at the North; the duration of the campaigns in each section was about the same-four years. The crowning victory at Yorktown was due in about equal measure to the previous campaigns on each side of the Potomac, and to the skill with which Washington profited by the results of both.

${ }^{2}$ Dawson, 122-126.

${ }^{3}$ Dawson, 122-126. 
and 1,000 Colonial militia, called out by the Provincial Council and commanded by General Moore. It was disastrous to the tories; 30 of them were killed or wounded, their leader and 850 men were captured and the rest fled; the Colonials lost only two men slightly wounded, and they captured a large quantity of supplies, including 1,500 rifles and a military chest containing $£ 15,000$ in specie. $^{1}$

Arrival of

Regular

Troops

Feb. 13

May 3

Jan.

June 4

June 9

Preparations for the

Defence of

Charleston

1775

June 26

Nov. 4

Dec. 28

May

Meanwhile the regular troops which had been called for were on their way. Cornwallis, with 7 regiments, convoyed by a squadron of 2 ships of the line and 6 frigates mounting in all 230 guns, sailed from Cork and arrived at the mouth of the Cape Fear River. Clinton was already there, having been despatched from Boston with parts of 2 regiments. He was senior to Cornwallis and took command of all the troops. He decided to proceed to the attack of Charleston, where he arrived outside the bar, and soon after landed part of his troops on Long Island. ${ }^{2}$

On the American side preparations were not lacking to defend the South. By successive resolutions Congress requested North Carolina to raise 2 battalions, South Carolina 3, Georgia 1, and Virginia 6-all to be on the Continental establishment. ${ }^{3}$ It was some time before these troops were raised, but meanwhile South Carolina was taking energetic measures for its own defence. Several months before Congress passed its resolutions the State had raised 4 regiments of its own; and having learned, by intercepted despatches ${ }^{4}$ to the royal governor, first that it was intended to send regular troops to coerce the South, and later that Cornwallis with his 7 regiments

${ }^{1}$ Dawson, 128-134.

${ }^{3}$ Jour. Cont. Cong., II, 107, 325, 463.

${ }^{2}$ Ibid., 135, 140, 142.

Lossing, II, 543. 
was about to sail from Cork, the State began the construction of elaborate fortifications to defend Charleston harbor. ${ }^{1}$ These were not quite finished when Parker's fleet with Clinton's and Cornwallis's soldiers appeared off the bar. Simultaneously 2 battalions arrived from June Virginia and 1 from North Carolina, carrying the total strength of the garrison (including militia) to more than 6,000 men. ${ }^{2}$ Charles Lee, who had been sent from Boston by Washington, arrived at the same time and took command. The fortifications were constructed on Sullivan's Island, on the north side of the entrance to the harbor; on James Island, on its south side; at Haddrell's Point, nearer to the city; and on the wharves of the city itself. ${ }^{3}$ In all they mounted nearly 100 cannon; and there was a good supply of powder on hand, part of which had been purchased in the West Indies a year before and part of it captured from a British supply ship at St. Augustine, by a cruiser which the gentlemen of Charleston had fitted out for that purpose. The principal fort was on the southern side of Sullivan's Island; and under the name of Fort Moultrie that point has ever since been strongly fortified. In 1776 its fort had 4 bastions and was made of soft palmetto logs and earth, with a deep ditch, and parapets 16 feet thick mounting 30 guns. It was large enough for a garrison of 1,000 men, but its defenders numbered only 344, the 2d South Carolina Regiment, under command of Colonel William Moultrie. ${ }^{4}$ The 1st Regiment, Colonel Gadsden, was at Fort Johnson on James Island, and the 3d Regiment, Colonel Thomson, was on the eastern end of Sullivan's Island; he was to

${ }^{1}$ Moultrie's Memoirs of the American Revolution, I, 140.

${ }^{2}$ Marshall's Washington, I, 72.

'Moultrie, I, 142, 146.

' Gordon, II, 283; Lossing, II, 544-546. 
Defence of Charleston

June 4

June 28

June 28

Attack on Sullivan's Island oppose any attempt of Clinton's men to cross the inlet known as the "Breach," which separated Long Island from Sullivan's. The rest of the defending force was distributed at Haddrell's Point, where Lee had his headquarters, and in the city. ${ }^{1}$

The soul of the defence was Moultrie. ${ }^{2}$ Lee arrived three weeks before the attack began and gave a great many orders, most of them foolish; but his reputation was so great on account of his alleged services in various European armies that he was looked up to as a great soldier and cheerfully obeyed. He gave it as his opinion that Fort Moultrie would be a "mere slaughter pen"" and would have to be abandoned; and in the orders which he kept sending to Moultrie, ${ }^{3}$ he impressed daily upon him the importance of securing his retreat and his impatience that a bridge of boats, which he had ordered to be built, was not finished. Moultrie built the bridge as ordered, but he remained in the fort; and he afterward wrote that he "never was uneasy on not having a retreat" because he did not imagine that the enemy could force him "to that necessity." 4

Three weeks were spent by Parker and Clinton in getting the ships over the bar, landing the troops on Long Island and making other preparations. ${ }^{5}$ Finally the attack was made. Two ships of the line and two frigates were to sail in under topsails and anchor off Fort Sullivan; three frigates were to pass them on the west and anchor between Fort Sullivan and the city where

${ }^{1}$ Gordon, II, 283.

${ }^{2}$ Fiske, Amer. Rev., I, 198, 199; Amer. Archives, 4, VI, 1191.

${ }^{3}$ More than twenty of these have been preserved. (Amer. Archives, 4, VI, 1186.)

Lossing, II, 547.

${ }^{5}$ Stedman, I, 186; Lee's Report, Sparks, Letters, I, 243-247; Lossing, II, 548-550. 


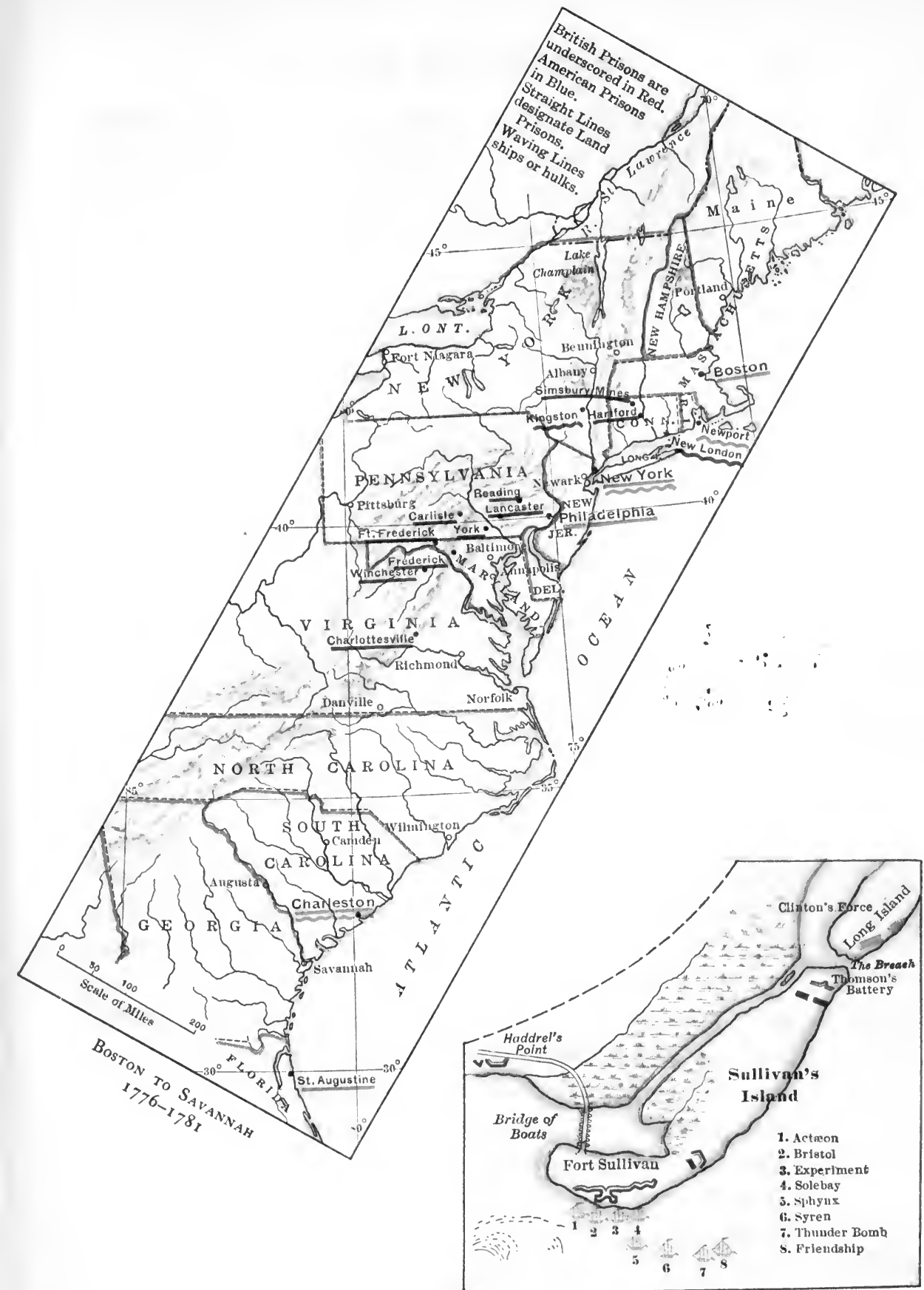

Sullivan's Island (Charleston) June 29,1776 


$$
\begin{aligned}
& \because \because z=\cdots \\
& \cdots, \quad \therefore
\end{aligned}
$$


they could enfilade the fort and bombard its western side 1776 which was not quite finished. A bomb-ship, or mortarboat, escorted by the remaining frigate was to anchor south-east of the fort and bombard it from that side. Clinton's troops were to cross the "Breach" inlet from Long Island, in boats or by fording, drive back Thomson's regiment and take the fort in the rear.

The ships went in as ordered; but Clinton's men never got across the inlet. It proved to be full of sand-bars, on which the water was only a few inches deep, and the boats ran aground; and between these were deep holes where the men sank in up to their necks. Thomson's regiment also opened fire on them. They returned to Long Island and took no part in the battle.

The action thus devolved entirely on the navy. For June 28 . ten hours they bombarded the fort, and the fort replied 11 A. M. to with equal spirit. In the middle of the action the flagship (Bristol) swung around so as to be exposed to enfilade, and Moultrie's men swept her decks so effectively that every man on them was killed or wounded. ${ }^{1}$ The ships were at such close range that musketry fire was used with deadly effect. The mortar-boat was disabled early in the action; and the three frigates, which were to pass the rest of the squadron and take position between the fort and the city, grounded on the "Middle Shoal" (where Fort Sumter was afterward built). Two of them got off after a few hours, but the third stuck fast, and was abandoned and blown up the following morning.

After darkness had set in and the tide was running ebb, having made no impression on the fort Parker withdrew out of range to his former anchorage in the "Five Fathom Hole." He had lost 64 killed and 161 wounded; one of

1 Parker's Report, Dawson, 141. 
1776 his ships had been struck 70 times, one was abandoned and the others were so seriously injured that it was several months before the repairs were completed. The loss in the fort had been only 17 killed and 20 wounded. ${ }^{1}$ Parker and Clinton remained for three weeks, repairing damages. Then Clinton sailed north convoyed by the one frigate that was in condition to go to sea. He ar-

Aug. 1 rived on Staten Island in time to take part in the attack on New York. ${ }^{2}$

Results of the British Defeat at Charleston

The defence of Charleston was a brilliant victory. Seven newly organized regiments, which had never before been under fire, had beaten off 7 regiments of regulars and 8 ships of war whose guns outnumbered 6 to 1 those of Fort Sullivan. It inspirited the South, cheered the whole country and disheartened the British. They made no further movements in the South for two and a half years. The Continental battalions of the four Southern States, which in 1777 were increased to 31 in number, ${ }^{3}$ were duly organized; and in the absence of military operations near their homes they were available for ser-

1777 vice under Washington. The entire quota of Virginia and North Carolina (24 battalions) were ordered to join Washington; they were engaged in the battles around Philadelphia, and they remained with him until the British began anew their attack on the South.

1778

This renewal began in the winter of 1778-79. Washington was then at Middlebrook, ${ }^{4}$ with his troops in cantonments through the Highlands to Connecticut. Clinton had 27,803 men (exclusive of officers) at New York and 5,789 at Newport. Before leaving Philadelphia he had

1 Lee's Report, Dawson, 139.

3our. Cont. Cong., VII, 90, 133.

${ }^{5}$ Sparks, V, 542.
2 Sparks, IV, 27.

- Ante, p, 155. 
received instructions, due to the French alliance, to 1778 send 5,000 men to St. Lucia and 3,000 to Georgia or Florida; to abandon offensive operations at the North; and in the following winter to make an attack on the Southern Colonies. "Georgia should be first taken, and the passage into South Carolina will then be compara- March 8 tively easy." 1

March 21

The retreat to New York and the operations at Newport delayed for several months the execution of these orders; but toward the close of the year these expeditions left New York for their destinations, the first for St. Nov. 4 Lucia and the second for Georgia. The latter consisted Nov. 27 of 2 British battalions, 2 Hessian battalions, 4 battalions of New York tories under Cruger and De Lancey and a British Troops Sent to detachment of royal artillery-numbering in all about 3,500 men, and commanded by Lieutenant-Colonel Archibald Campbell of the 71st Highlanders. Convoyed by a British squadron under Commodore Hyde Parker, it arrived safely at Tybee Island, at the mouth of the Dec. 23 Savannah River. ${ }^{2}$

These movements were not made without the knowledge of Washington and of Congress; and it was also Partisan Operations known that the predatory warfare which had been carried on during the last two years between the Georgia loyalists who had taken refuge in Florida, on the one side, and the Colonial militia of Georgia and South Carolina under Major-General Robert Howe, on the other side, had resulted adversely to the latter; and that the former were now preparing to invade both Georgia and South Carolina. Congress thereupon passed resolutions requesting the Governor of Virginia to forward 1,000 men oct. 17

${ }^{1}$ Germain to Clinton, Sparks, V, 549.

2 Campbell's Report, Dawson, 477. 
1778 and the Governor of North Carolina to send 3,000 men, Sept. 25 for the defence of the other two Southern States; and at the same time directed Howe to repair to Washington's head-quarters and Lincoln to take his place as commander of the Southern Department. ${ }^{1}$ These resolutions were passed without consulting Washington, but he fully concurred in the selection of Lincoln in whom he had the

Dec. 19

Situation at the South When Lincoln Took Command highest confidence. When Lincoln arrived at Charleston the situation was as follows: Campbell with 3,500 men on transports was approaching the mouth of the Savannah River; Prevost with 2,000 men was moving north from Florida, part of his force marching by land and part of them being transported by water; these two forces were to effect a junction and under Prevost's orders were to conquer Georgia first and then South Carolina; ${ }^{2}$ Robert Howe, with about 1,000 (1st and 2d Georgia, 3d and 4th South Carolina and some Georgia militia) was at Fort Sunbury (the site of Fort McAllister in the Civil War), about 20 miles south of Savannah; Lincoln was at Charleston, with perhaps 1,500 men (1st and 2d South Carolina and some militia); the North Carolina and Virginia troops were assembling, and part of them were on the march but none of them had yet arrived. ${ }^{3}$

Abouı Dec. 25 Howe heard of the arrival of Campbell off the Savannah River and of the approach of Prevost from Florida at the same time. Leaving part of his force at Sunbury, he quickly marched back to the defence of Savannah. On arriving there he posted his little force as follows: the Georgia regiments on the east of the town with their left flank on the river; the South Carolina regiments across the road leading into town from the south-east,

1 Jour. Cont. Cong., XII, 950, 951, 1021; Sparks, VI, 74, 83.

${ }^{2}$ Germain to Clinton, Sparks, V, 549. ${ }^{3}$ Lossing, II, 525. 
their right flank protected by a swamp, and one com1778 pany in advance on a hill about two miles down the river; the Georgia militia in observation on the main road leading into town from the south. ${ }^{1}$

While Howe was making these dispositions, Campbell had reconnoitred the river and captured some citizens Capture of Savannah who gave him quite accurate information in regard to the situation at Savannah and the small force opposed to him. He decided to attack without waiting for a junction with Prevost. Accordingly the ships came over the bar, sailed up the river with a flood tide and anchored about two miles below the city. At daybreak Dec. 28 the debarkation began, and the first troops who landed Dec. 29 climbed the bluff (where Fort Jackson was afterward built) and were received by a smart fire from the company of the Carolina regiment, in which 3 Highlanders were killed and 5 wounded. But this company was completely outnumbered and driven back and the debarkation then proceeded. When this was completed, 2 г.м. Campbell moved forward to within 1,000 yards of Howe's position; he then made a feint against Howe's left, near the river, and at the same time sent his light infantry supported by one of the New York tory battalions accompanied by a negro guide, who led them along a blind path 3 r. s. through the swamp on Howe's right. These came out of the swamp on the main Ogeechee Road, and brushing aside the Georgia militia they were directly in rear of Howe. Simultaneously Campbell attacked Howe in front. Completely overpowered by such superior numbers, Howe and the two Carolina regiments made their escape through the town and across the swamps to the west of it. But the Georgia troops, who were on

${ }^{1}$ Dawson, 474; Campbell's Report, Dawson, 478. 
1778 Howe's left, were less fortunate and were nearly all captured.

Campbell's losses were only 7 killed and 19 wounded; he captured 38 officers and 415 men, besides 45 cannon, 23 mortars and a large amount of ammunition and stores. He states that 83 Americans were found dead in Savannah and 11 wounded; a considerable number were drowned in attempting to escape through the swamps. ${ }^{1}$

The British victory was complete. Howe was tried by court-martial, ${ }^{2}$ but was acquitted and served under Washington until the close of the war. ${ }^{3}$

Meanwhile Prevost was marching north through Georgia. ${ }^{4}$ He met with slight resistance at Fort Sunbury,

1779 and captured the place and its garrison of 200 men withJan. 6 out difficulty. Then he pressed on to Savannah, effected

Jan. 19 his junction with Campbell, took command of the united forces and promptly sent Campbell up the river 120 miles to Augusta. This place was also taken without serious opposition, the Provincial militia retreating as Campbell approached. Leaving a garrison at Augusta, Campbell proceeded to establish posts at various places in western Georgia. ${ }^{5}$

Within six weeks from the time Campbell landed at Savannah the conquest of Georgia was complete, and the royal governor was requested to return from England and resume his government. ${ }^{6}$

1 Dawson, Campbell's Report, 477-479.

${ }^{2}$ Sparks, V, 451.

${ }^{3}$ Ibid., VI, 299; VII, 74-88, 94, 363, 382, 563; VIII, 457.

4 If contemporary accounts are to be relied upon, the damage to private property on this march, and the one which soon followed it from Savannah to Charleston, was even greater than that on the more famous march through Georgia eighty-six years later. (See Gordon, III, 259, 261.)

'Stedman, II, 106-108.

${ }^{\circ}$ Lossing, II, 528. 


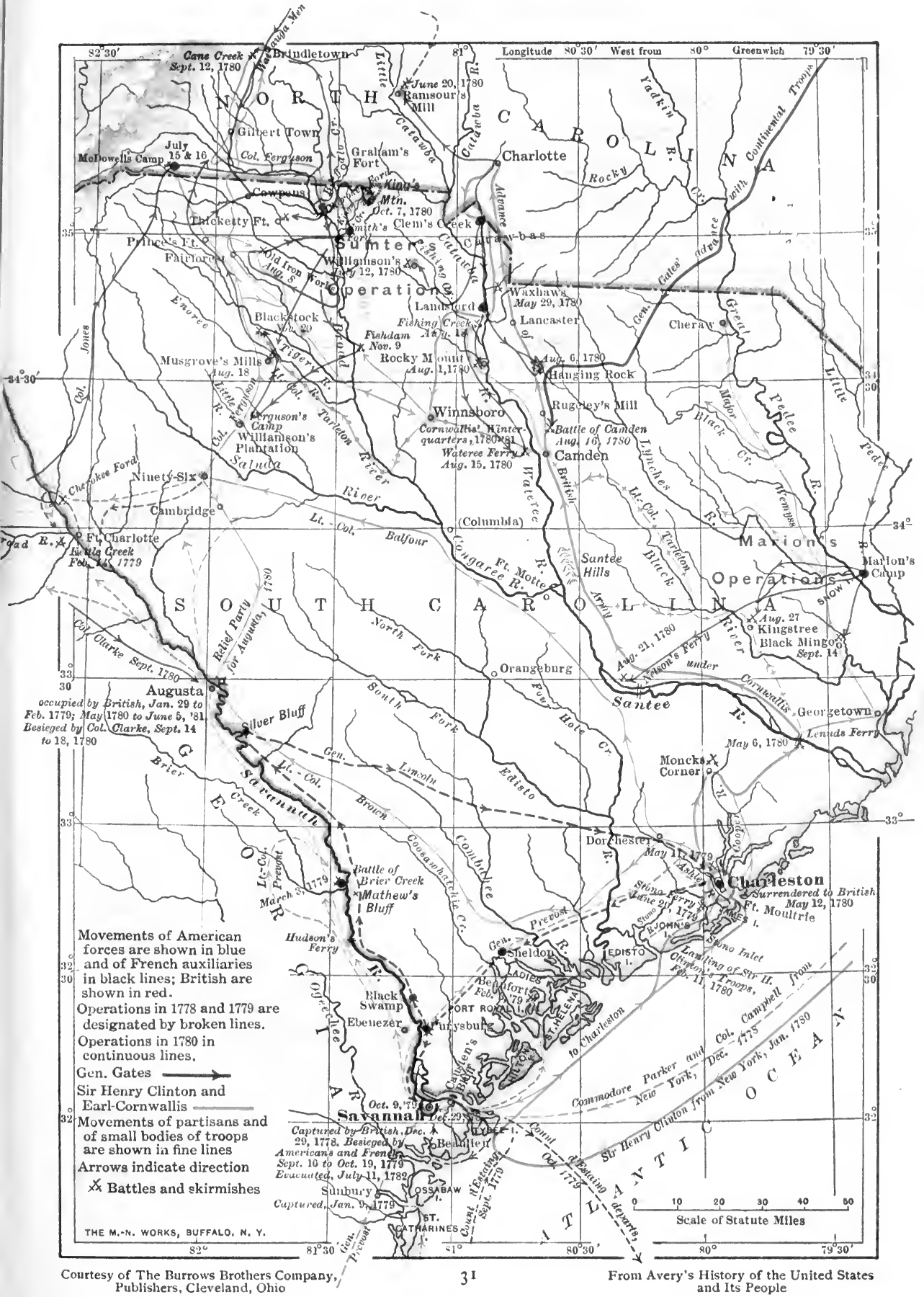



Lincoln, however, was not disposed to give up South 1779 Carolina without a struggle, and he even contemplated an attempt to reconquer Georgia. ${ }^{1}$ Additional militia had come in and the North Carolina regiments were beginning to arrive. With these and the troops which he had found at Charleston on his arrival, he made up a force of about 3,500 men, of whom 1,000 were counted as "regulars" because they were on the Continental establishment, 1,400 were armed militia and 1,000 were unarmed, undisciplined and untractable men. With this force he marched toward Savannah, but it fell before Defence of South he arrived, and picking up the remnants of the garrison which had escaped with Howe, he took post on the east Jan. 3 bank of the river, at the hamlet of Purysburg, about 15 miles above Savannah.

Nearly opposite to him, at the hamlet of Ebenezer, was Prevost, whose force of more than 5,000 men, the greater part of them British regulars, was stationed at various points along the river from Savannah to Augusta, with some outlying posts in the western part of the State. ${ }^{2}$

Notwithstanding the odds against him, the stouthearted Lincoln proceeded with his plans, not only to defend South Carolina but to recapture Georgia. Some preliminary skirmishes, resulting favorably to the Americans, confirmed his intentions in this respect. At Beau- Action at fort, on Port Royal Island, a force of four companies of regulars, sent by sea to capture that island, was met and Feb. 3 defeated by the militia which Moultrie brought out from Charleston to oppose them. Ten days later, in the upper

${ }^{1}$ Lincoln to Washington, Sparks, Letters, II, 245.

${ }^{2}$ Lossing, II, 552; Gordon, III, 229; Marshall, II, 296; Dawson, 480; Life of Lincoln. 
1779 part of Georgia, 160 miles from the sea-coast, the tory

Engagement at Kettle Creek

Feb. 14

Lincoln Takes the Offensive militia under Colonel Boyd had a collision with the Provincial militia under Colonel Andrew Pickens. The locality was on Kettle Creek, Wilkes County, beyond Augusta. Boyd was severely wounded, more than 40 of his men were killed, a large number wounded, 75 were captured and the rest dispersed. The captives were all tried for treason and 5 of them were hanged. Pickens lost only 9 killed and 23 wounded. ${ }^{1}$ The tory militia of the Carolinas never afterward assembled in sufficient numbers to give any trouble.

Encouraged by these successes, Lincoln, whose force had increased to between 6,000 and 7,000 men by the arrival of North Carolina and Virginia troops and the gathering of militia, now felt strong enough to take the offensive. For this purpose he sent Ashe with 1,500 men up the east bank of the river to attack Augusta. ${ }^{2}$ Prevost then realized that his force was too much scattered; he drew in the outlying garrisons in the upper part of the State, and uniting them with that of Augusta under Campbell marched them all down the west bank of the river, intending to concentrate his entire force at Ebenezer. ${ }^{3}$ When Lincoln heard of this he ordered Ashe to follow Campbell down the west bank; and Ashe did so, going into camp in the angle between Briar Creek and the river, about 53 miles above Savannah.

Then Prevost planned and carried out an admirable counter-stroke. He sent his younger brother, LieutenantColonel Prevost, with portions of the 60th and 71st Regiments, some light infantry, a troop of cavalry and some Provincials-in all about 900 men-to make a

'Dawson, 481.

I Ibid., 487.

' Ibid., Lincoln's Report, 492; Prevost's Report, 493. 
détour of about 50 miles, crossing Briar Creek far above 1779 Ashe's camp and coming down on his rear. In order to divert Ashe's attention from the real movement a demonstration was made against his front by one battalion of the 71st Regiment.

The movement was carried out as smoothly as at an annual manœuvre. Ashe was completely surprised and ignominiously defeated. Only 450 of his men rejoined Lincoln's army. The rest-more than two-thirds of the whole force-were lost. About 150 were killed or wounded; as many more were drowned in attempting to cross the river; 27 officers and nearly 200 men were taken prisoners; nearly 600 succeeded in escaping and went home. Young Prevost lost 5 killed and 11 wounded. ${ }^{1}$

Ashe was tried by court-martial and severely censured; he was soon after taken prisoner, contracted small-pox and died. He was a patriot of the highest character, but without military experience or instinct. ${ }^{2}$

This brilliant action of the British destroyed the possibility of recovering Georgia at that time. But Lincoln, Lincoln Advances to whose courage and determination were perhaps greater than his military skill, did not think so. He determined to cross the Savannah River, cut off the enemy's communications with the back country and protect the legislature which had been summoned to meet at Augusta. ${ }^{3}$ Leaving about 1,000 men under Moultrie on the lower river, at Purysburg and the Black Swamp, with the other 4,000 men of his command he marched up the river, Apri 23 crossed it and moved on toward Augusta. ${ }^{3}$ In so doing he uncovered the road to Charleston, unless Moultrie could hold Purysburg.

${ }^{1}$ Dawson, 489-491; Lincoln's Report, 493; Prevost's Report, 494.
${ }^{2}$ Dawson, 494.
${ }^{3}$ Ibid., 495, 496. 
1779

April 29

Prevost Advances to Charleston

May 10

Feb. 2

May 11

May 12

As soon as Prevost detected the movement he advanced against Purysburg, intending at first only to make a demonstration which would bring Lincoln back. But as Moultrie's force was too small to oppose him, and as Prevost met less resistance than he had anticipated, he pushed on to Charleston, driving Moultrie before him. Expresses had been sent to Lincoln begging him to return; but he believed that Prevost's movement was only a feint and he was not to be deterred from his intention of going to Augusta.

Finally, Prevost crossed the Ashley River and appeared before Charleston. The situation there was desperate, but the people were energetic; the fortifications had all been on the side toward the sea, but during Prevost's advance lines were laid out on the land side, between the Ashley and Cooper Rivers, and their construction vigorously pushed; the slaves were armed; the entire ablebodied population turned out as militia. Fortunately, Pulaski's Legion, ${ }^{1}$ which had been ordered by Congress from New Jersey to the South, had just completed its sixty days' march, and arrived at the same time as Prevost. ${ }^{2}$

The next day Prevost summoned the town to surrender, and some rather discreditable proposals were put for-

${ }^{1}$ Pulaski was a Polish revolutionist who had been obliged to flee from his own country in 1771, and after serving in the Turkish army had come to America in 1777. Congress made him a brigadier-general, and he served at the Brandywine and Germantown. By resolution of March 28, 1778, Congress authorized him to raise and command "an independent corps of 68 horse and 200 foot, the horse to be armed with lances and the foot to be equipped as light infantry." It was called "Pulaski's Legion," and was independent of and additional to the regular military establishment planned by Steuben and adopted by Congress, May 27, 1778. Congress considered this legion as under its special orders, and by frequent resolutions ordered it from one point to another. (Jour. Cont. Cong., $\mathrm{X}$, 291; XII, 983; XIII, 132.)

${ }^{2}$ Dawson, 496-498. 
ward by the defenders that South Carolina should remain 1779 neutral during the rest of the war and its status be determined by the treaty of peace when made; Prevost rejected this and demanded an unconditional surrender. This was refused, and the town prepared to receive an assault. ${ }^{1}$

Prevost, however, did not assault. Lincoln was already marching to the relief of Charleston; he had persisted in his intention of going to Augusta, but the news he received there from Charleston convinced him that Prevost intended something more serious than a feint, and he was now hurrying back with all possible speed. Prevost intercepted a letter from Lincoln to Moultrie telling of his approach, and he also knew of Pulaski's arrival; his force was less than 3,000 men, far inferior to that of Lincoln; the defenders' trenches were strong, and could not be carried without heavy loss.

Prevost therefore determined to withdraw from Charleston. ${ }^{2}$ As Lincoln was advancing by the road Prevost Withdraws from from Savannah, Prevost was forced to retire by the islands which, with numerous marshes and inlets, form the sea-coast from Charleston to Savannah. He had abundant shipping to facilitate such a movement. $\mathrm{He}$ therefore crossed the Ashley River during the night, May 13 marched over to Stono Inlet, crossed that and established himself on John's Island. To protect his position and permit him to withdraw gradually and without molestation to Savannah, a bridge-head was constructed on the main-land at Stono Ferry. It consisted of three strong redoubts, with heavy abatis in front; and in its rear was a bridge of boats to John's Island.

${ }^{1}$ Gordon, III, 257; Lossing, II, 554; Marshall, I, 299; Stedman, II, 112.

2 Dawson, 498, 499; Stedman, II, 112-115. 
1779 The troops were gradually sent back through the Sea Islands to Savannah, until finally only the rear guard remained at Stono Ferry. It consisted of one battalion of the 71st Highlanders, the Hessian regiment Von Trumbach, a detachment of artillery and some Carolina loyalists-in all about 900 men. All the boats but one had been taken away in connection with the withdrawal of the other troops through the Sea Islands, and this rear guard was thus in a somewhat perilous position.

Lincoln determined to attack and if possible capture it. He now had between 6,000 and 7,000 men in Charleston, but he only brought 1,200 men into action. His plan was to send Moultrie, "with all the troops that can be spared from Charleston," to make a demonstration on James Island so as to prevent reinforcements from coming to the assistance of the rear guard, and if circumstances were favorable to land his men on John's Island and cut off their retreat. The real movement was under Lincoln's own direction, and was an attack on the mainland against the bridge-head. ${ }^{1}$

June 20

Battle of Stono Ferry

Lincoln crossed the Ashley River soon after midnight and began his march across to Stono Ferry, a distance of about 8 miles. His left wing consisted of the South Carolina Continentals under Huger; his right, of the Carolina militia; in the reserve were the Virginia militia; and he had 6 pieces of artillery and a small body of cavalry. He had to advance through a dense growth of pine saplings on one flank and "an open forest of stately pines" on the other flank; and it was difficult to maintain connection between them. But a little after

7 A. M. sunrise he approached the redoubts. The Hessians retreated; but 2 companies of the Highlanders made

${ }^{1}$ Dawson, 499, 500; Lowell, 241; Lee's Memoirs, 130, 131. 
such a stout defence that, according to Stedman, only

11 men succeeded in making their retreat, all the rest being either killed or wounded. ${ }^{1}$

The entire British force was then brought into action, and there was stiff fighting at close quarters, and sometimes hand to hand with the bayonet, for about an hour. Then reinforcements from the western end of John's Island came in sight. It was to prevent this that Moultrie had been sent by way of James Island; but through some misunderstanding there was delay in Moultrie's movements and he did not arrive in time. ${ }^{2}$

Lincoln therefore ordered a retreat, and he moved back to Charleston in good order. The British followed him a short distance and then abandoned the pursuit. The Americans lost 146 killed and wounded and 165 missing. The British loss was 26 killed, 103 wounded and 1 missing. ${ }^{3}$

Lincoln did not again molest Prevost, and the latter retired slowly from island to island, and finally reached Savannah. An outpost was left at Beaufort, on Port Royal Island.

The sickly season and intense heat put a stop to all military operations for the next two months. During this interval, Governor Rutledge, Lincoln, the French consul and the citizens of Charleston-all wrote letters to d'Estaing, begging him to come to their assistance. D'Estaing had promised to be on the American coast in May, but he stayed in the West Indies to capture St. Vincent and Grenada." Then he sailed for Haiti, and there the letters from Charleston safely reached him. ${ }^{\mathrm{s}}$

1 Stedman, II, 117.

2 Dawson, 500; Prevost's Report, 503.

Dawson, 500; Prevost's Report, 503.

Ante, p. 171.

s Sparks, VI, 359. 
1779

Sept. 4

D'Estaing Returns to America

Sept. 9

D'Estaing Lands

Sept. 12

Sept. 13

He decided to sail for Savannah. His arrival was so unexpected that off the mouth of the river he captured a British ship of the line, a frigate and two supply ships. ${ }^{1}$ Prevost promptly called in his outlying detachments, at Sunbury and Beaufort, and prepared for defence; and Lincoln with equal alacrity marched toward Savannah.

D'Estaing brought with him 6,000 soldiers and a squadron of 37 ships with over 2,000 guns. ${ }^{2}$ Compared with this the British ships on the Southern coast were insignificant. Prevost had less than 3,000 men. ${ }^{2}$ Lincoln had about 1,000 Continentals, ${ }^{2}$ and a few months before he had gathered together nearly 5,000 militia. Adding these to the 6,000 of d'Estaing, Prevost was outnumbered 4 to 1 . With good leadership and prompt action there was now an opportunity to capture Prevost's entire force; then proceed to the North, fight the British fleet, which was inferior to d'Estaing's, unite with Washington in an attack on New York and end the war. But these proved to be idle dreams; for the leadership was poor and the action was slow.

D'Estaing had sent some of his ships in advance to Charleston to concert plans with Lincoln; when his main body anchored off Tybee Island; small vessels were arriving from Charleston to aid in landing his troops, and Lincoln was on the march from Charleston.

It was decided to make the landing through Ossabaw Sound, about 12 miles south of Tybee Island; the troops came ashore at a plantation called Beaulieu, about 8 miles due south of Savannah. D'Estaing landed only 3,500 men, but with these he marched to Savannah the next day and demanded a "surrender to the arms of

${ }^{1}$ Dawson, 563; Stedman, II, 122-123.

${ }^{2}$ Keim, 255. 
the King of France." 1 Prevost asked for twenty-four hours to consider it, his object being to gain time till the arrival of the Beaufort garrison; he then declined to surrender. Some skirmishing took place during the sept. 16 next three days, and then Lincoln arrived, having crossed the river several miles above Savannah. He brought Lincoln Joins d'Estaing at with him, however, only 600 Continentals and 750 militia. ${ }^{2}$ His militia came and went at their own will, and rendered obedience-and not much of that-only to the State officials. On four days' notice it was probably not possible for Lincoln to despatch a larger force.

Twelve days had now elapsed since d'Estaing's fleet had first been sighted, and during that time Prevost and Defence of Savannah his engineers and other officers had been working with tremendous energy. ${ }^{2}$ The 4 men-of-war had retired up the river; their guns and sailors were being landed to take positions in the trenches; 2 of the ships and 4 transports had been sunk in the river, blocking the channel below the town; smaller vessels had been scuttled and a boom stretched across the river above the town to prevent fire rafts from coming down; gangs of 4,000 negroes had been working in reliefs, night and day, under the direction of the soldiers, in throwing up redoubts and trenches, cutting timber and building abatis. ${ }^{3}$ The line extended from the swamp on the west of the town around to the river on the east. It was about 1,100 yards long, and there were five strong redoubts made of soft wood and earth and connected by trenches, with traverses at suitable intervals. In these were posted the regulars and Provincials which Campbell had brought

${ }^{1}$ Dawson, 563; Stedman, II, 123-124.

2 Ibid., 564; ibid., II, 125-133; Lossing, II, 530.

${ }^{3}$ Ibid., 565; ibid., II, 125-133; Moultrie, II, 33; Gordon, III, 328-332; Lee's Memoirs, 55-60; Lossing, II, 528-531. 
from New York and Prevost from Florida. Prevost states their numbers at only 2,360 effective, but it is hard to reconcile this with the official reports of six months before when they numbered over 5,000, and in the meantime they had had no severe losses. Including the sailors, the volunteers from the transports and the negroes whom he armed, he probably had in the trenches fully 4,000 men.

Moultrie recorded his opinion that if the works had been assaulted the day after the Americans joined the French they would have been carried. D'Estaing and Lincoln thought differently, and decided on a siege. ${ }^{1}$ Artillery had to be landed from the ships and brought up from Beaulieu with insufficient transportation. 'A week went by before ground was broken for the approaches and ten days more before the artillery opened fire.

In the meantime Prevost had made two small sorties which were repulsed. This was of small consequence. The important thing was that he had gained in all eighteen more days for his negroes to work on the trenches and his sailors to mount their guns. When the allies made their junction he had only 12 guns in place; when their artillery was ready he had mounted 76 guns-pieces of 6,9 and 18 pounds.

oct. 4 Finally the cannonade opened and continued almost Oct. 9 without interruption for five days. Some houses were damaged and a few persons injured in the town; but no harm was done to the trenches or their defenders.

D'Estaing then became anxious. He was impatient to send some of his ships back to the West Indies and the rest to France. He had already been five weeks on the American coast. His engineers told him that it 

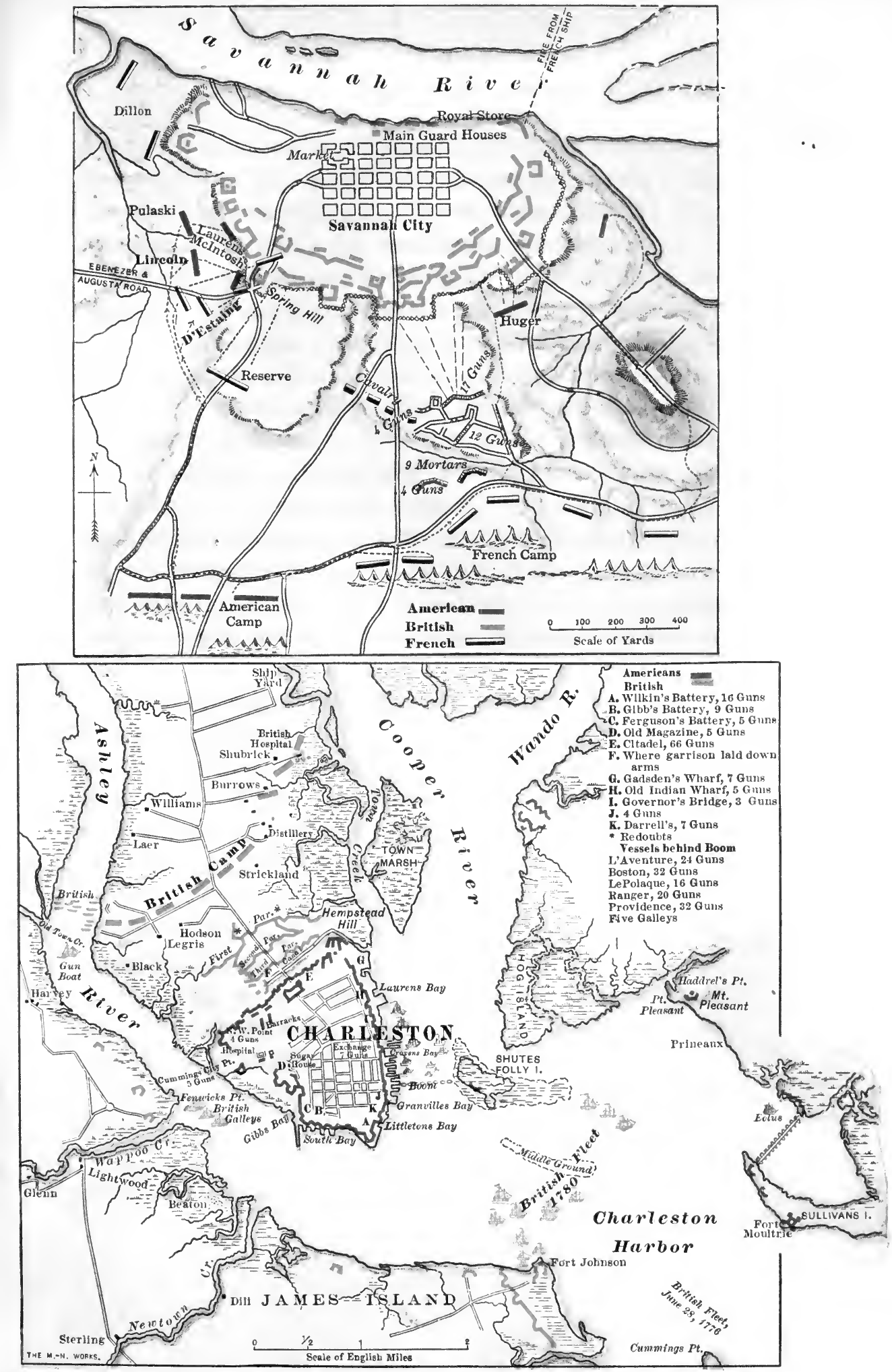

Courtesy of The Burrows Brothers Company, $32 \quad$ From Avery's History of the United States and Its People 
$\because$

, 
would take ten days more to complete the sap which was 1779 about 300 yards from British trenches just south of the town. He would not wait. It was either raise the siege or make an assault. ${ }^{1}$ He decided on the latter.

The allied camp was about 1,200 yards south of the The Allies British lines; the French on the right, the Americans on Assault the the left. The plan of assault was to send Huger with the South Carolina militia to make a demonstration against the works on the east or left of the British line; while the main attack was to be made on the opposite flank, in two columns. One of these, under Count Dillon, was to make its way along the base of the bluff and on the edge of the swamp, where it would be protected from British fire, and when near the river it was to climb the bluff and attack the Sailor's Battery, which formed the extreme right of the British lines. ${ }^{1}$ The other column was to be led by d'Estaing and Lincoln and was to attack the Spring Hill redoubt, at the south-west angle of the lines, where the road from Augusta rose to the bluff from the causeway across the swamp. There were 3,500 French and 850 Americans in the two columns. The troops were to move at 4 o'clock in the morning so as to make the assault at dawn.

There was delay, however, in getting started, and it oct. 9 was broad daylight when Dillon, who had lost his way in the swamp, was discovered. He was not near enough to the bluff to be sheltered from fire, and after losing heavily he retreated to camp without having reached the enemy's lines at all.

The other column made a fierce attack and was warmly received. That portion of the lines was commanded by

${ }^{1}$ Dawson, 565; Stedman, II, 125-133; Moultrie, II, 33; Gordon, III, 328-332; Lee's Memoirs, 55-60; Lossing, II, 528-531. 
Lieutenant-Colonel Maitland, the competent officer who had so successfully defended the bridge-head at Stono Ferry four months before. A Charleston sergeant who had deserted the day before had told him of the preparations for the assault, and while Maitland's force (one battalion of 71st Regiment, one battalion of 60 th and a company of marines) was far inferior in numbers to the assailants, he was ready to make a vigorous defence.

The attack was made with the greatest gallantry. Although the column was exposed to the direct fire of the Spring Hill redoubt and to the cross-fire of the works on either side of it, yet the men pressed on until the colors of France and Carolina were planted on the parapet. A desperate hand-to-hand encounter continued for fiftyfive minutes. D'Estaing was twice wounded, although not severely. Pulaski was horribly mangled, receiving wounds from which he died in a few days. The troops that did not reach the parapet were crowded in the ditch and on the glacis; and the Highlanders came out of their trenches on the left of the redoubt and mowed down the assailants with a terrible enfilade fire. Three standard-bearers of the Carolina colors, two lieutenants and a sergeant were killed in succession on top of the parapet.

But the British did not yield an inch. They had driven back Huger when he made his demonstration on the opposite flank, and they now began to bring reinforcements from that flank to support Maitland. The losses of the French and Americans were so heavy that they were finally forced to yield, and they retreated to their camps.

The British loss was 40 killed, 63 wounded and 52 missing. The allies lost 16 officers and 228 men killed 
and 63 officers and 521 men wounded, a total of 8371779 nearly six times as many as the defenders. ${ }^{1}$ It was the severest fighting since Bunker Hill-a fierce assault and a splendid defence. The loss of officers, particularly the Americans, shows how gallantly they led their men, and seems to justify Moultrie's opinion that if the assault had been made when the allies made their junction three weeks before, and when the British works were only partially completed, it would have succeeded.

The assault having been tried, and having failed, Lincoln was for continuing the siege; but d'Estaing would not hear of it. He raised the siege at once and returned to his ships: Sending some of these to the West Indies, with the others he sailed for France ${ }^{2}$-on the same day that Washington wrote to Lafayette: "We have been in hourly expectation, for the last fifteen days, of seeing The Allies Raise the Siege

Oct. 20 D'Estaing Sails for Count d'Estaing off Sandy Hook." 3 Henry Lee and Du Portail and Hamilton were on the Jersey coast watching for d'Estaing's arrival in order that they might deliver the letters which Washington had addressed to him in regard to joint operations after his arrival. ${ }^{4}$ But he did not come their way.

When d'Estaing left Savannah Lincoln was, of course, forced to march back to Charleston.

D'Estaing mismanaged affairs at Savannah as badly as he had at Newport in the previous year. The feeling against him was very bitter. The South was terribly disheartened; and the militia, which had been gathering in large numbers at Charleston, went home. The British were correspondingly elated.

1 Dawson, 565; Stedman, II, 125-133; Moultrie, II, 33; Gordon, III, 328-332; Lee's Memoirs, 55-60; Lossing, II, 528-531.
2 Dawson, 569.
Sparks, VI, 383.
Ante, p. 171. 
1779 When Clinton heard of d'Estaing's arrival on the

Oct. 25

Clinton's Expedition to the South
Dec. 26

1780

Jan. 30 Southern coast he recalled to New York the 6,000 men who had so long been doing nothing at Newport; and as soon as news arrived of d'Estaing's defeat and departure for France, he determined to leave Knyphausen in command at New York, while he himself went to the South, taking Cornwallis with him as second in command, to try a second time to capture Charleston, believing that if successful he could complete the conquest of the South and restore the entire section to the British crown. He also planned to operate on an entirely different line from that which he adopted in 1776. Having now a base at Savannah, that was his destination; and from there he intended to move along the islands, following in an opposite direction the route of Campbell in the summer of 1779, and attack Charleston from the rear with his army, while the fleet assailed it in front. ${ }^{1}$

His expedition was of no small proportions-90 transports and supply ships, carrying 8 British and 5 Hessian regiments, besides Provincials and artillery and cavalry, in all about 8,500 men. They were convoyed by a fleet under Admiral Arbuthnot, consisting of 5 ships of the line and 9 frigates, with 650 guns and crews numbering probably 5,000 men. $^{2}$

The. ships sailed at a bad season, and off Hatteras encountered the winter gales; so that it was more than thirty days before the ships began arriving at Tybee Island. They had been scattered and dispersed on the voyage; an ordnance ship had foundered; a ship containing Hessians was driven across the ocean to be beached on the Cornwall coast of England, most of the

${ }^{1}$ Sparks, VI, 486; Lee's Memoirs, 62-75; Dawson, 570; Tarleton, 4, 35.

Dawson, 570, 571. 
artillery and cavalry horses perished; the stores, of which there was a plentiful supply, were damaged. ${ }^{1}$

After making a few of the most urgent repairs the fleet sailed up to North Edisto Inlet and the troops were Clinton Lands Near Charleslanded on John's Island about 30 miles south of Charles- Feb. 11 ton. Within a few days advance guards had crossed John's Island, and seized Stono Ferry, James Island, Wappoo Cut and the west bank of the Ashley River opposite Charleston. Lincoln at that time had only 1,400 Continentals and 1,000 militia. Clinton had more than 8,000 regulars. Had he acted with the same celerity which Campbell displayed at Savannah the year before, he could have captured Charleston and its small garrison, conquered the whole of South Carolina and then marched northward to the Chesapeake. But whereas Campbell captured Savannah in six days from the time his ships arrived off the mouth of the Savannah River, Clinton did not cross the Ashley River and begin serious opera- March 29 tions against Charleston until seven weeks after he was ashore.

In the meantime he had brought 1,200 men from Savannah and had sent about half of his transports back to New York for reinforcements; and the lighter ships of Arbuthnot's squadron had crossed the bar and anchored in Five Fathom Hole, to the south of Fort Moultrie. ${ }^{1}$

Lincoln had been doing whatever was possible with his slender resources. The lines across the peninsula, for Defence of from the Cooper to the Ashley Rivers, were completed and strengthened. Washington had already sent all the

1 Dawson, 570-578; Lee, 62-75; Tarleton, 1-84; Stedman, II, 176-195; Lowell, 244-247, 301; Eelking, 176-184. The reports of Clinton and Arbuthnot, the articles of capitulation and other official documents are given in full in Tarleton. 
North Carolina and Virginia Continentals which he had in his army ${ }^{1}$ and these arrived while Clinton was making his preparations to cross the Ashley River, or during the siege. The American squadron under Commodore Whipple-9 vessels and 248 guns-were at first disposed to contest the entrance of Arbuthnot's ships into the harbor; ${ }^{2}$ but it was not deemed strong enough for that purpose, and it was therefore withdrawn to the city; some of the guns were carried ashore and placed in the trenches, and 4 of the frigates and several merchantships were sunk in the two channels on either side of Shute's Folly (where Castle Pinckney was afterward built) at the mouth of the Cooper River. Their masts were connected by boom and chains, and chevaux-de-frise were placed on their decks. The passage into the Cooper River was thus effectually blocked; and behind the barrier was the rest of the squadron -5 vessels and 124 guns. $^{2}$ Lincoln was thus enabled to preserve his communications with the main-land and keep open a route for the reinforcements which were expected, or for a retreat, if that should be decided upon.

Finally, Clinton had completed his preparations, crossed the Ashley River in force and opened his first parallel

March 29

April 8

April 10 at 1,800 yards from Lincoln's works. A few days later Arbuthnot, with 7 frigates and 216 guns, ran by Fort Moultrie, with a loss of 27 men, and anchored between James Island and the city. ${ }^{1}$

Clinton and Arbuthnot united in a demand for surrender, and Lincoln sent back a brief but spirited refusal. The siege then began in earnest. ${ }^{3}$ Clinton had lost 60 ${ }^{1}$ Sparks, VI, 415.

2 See foot-note, p. 207.

${ }^{3}$ The most complete account of the siege of Charleston is that given in Moultrie's Memoirs of the American Revolution, II, 65-106, and Tarleton, 1-84. 
days in getting ready, and Lincoln had not been idle. 1780

Charleston was now surrounded by a series of redoubts and trenches, forming an irregular triangle whose three sides had a total length of nearly five miles. On the water sides were 9 batteries with 60 guns. ${ }^{1}$ On the land side there was a large hornwork astride the main road, "the Citadel," with 66 guns; in front of this a strong line of trenches, extending from river to river, and with a redoubt at each flank like a bastion, giving a flanking fire in front of the trenches; in front of this again, a wet ditch or canal, with a dam to retain the water at low tide; and in front of the canal a line of abatis and trous-de-loup.

The siege was carried on according to the scientific rules of the day, under the able direction of the chief engineer, Colonel Moncrieff, who had gained great reputation at the defence of Savannah. There were first, second and third parallels; saps, double saps and flying saps; and a sortie, in which 15 of the enemy were killed and 12 taken prisoners. Finally, on the twenty-eighth May 8 day, the counterscarp had been gained, the canal had been drained and the besiegers were ready to crown the scarp. Then Clinton sent a second summons to surrender. Lincoln replied, proposing impossible terms in order to gain time.

He was now nearly surrounded, and his communications with the North were practically severed. These Charleston communications had been maintained through a post at Monck's Corners, 30 miles north of Charleston, which was occupied by a detachment of Continental cavalry and some militia under Huger. Against this Clinton sent about 1,400 men; and a portion of this force under Tarleton surprised Huger and dispersed his command,

${ }^{1}$ See foot-note, p. 207. 
1780 of which they captured about 100 officers and men and April 14

May 6

April 18

April 24

Surrender of Fort Moultrie 400 horses - the latter being very useful in replacing the horses of "Tarleton's Legion" which had been injured and thrown overboard on the rough voyage from New York. Tarleton then pressed north, and at the crossing of the Santee River he defeated the mounted militia which was gathering at that point, inflicting on them a loss of 41 killed and wounded and 67 taken prisoners. ${ }^{1}$

May 7

Surrender of Charleston

May 12

Lord Rawdon, ${ }^{2}$ meanwhile, had arrived from New York with a reinforcement of 2,500 men, and had been assigned to the command of all the force operating on the east of the Cooper River; he soon captured the works at Haddrell's Point, and Arbuthnot then landed sailors and marines to assault Fort Moultrie from the land side while he bombarded it with his ships from the water side. When these preparations were completed the fort was surrounded, and it surrendered with its garrison of 291 men.

Lincoln was thus completely surrounded by a force which (including the reinforcements from New York and Savannah and the sailors who had been landed to man the siege-guns) numbered about 14,000 men. Further resistance was hopeless, and he signed the articles of capitulation which Clinton offered. The return of prisoners, signed by John André, deputy adjutant-general, numbers 7 generals, 290 other officers, 5,169 rank and file, including Continentals, militia and armed citizens5,466 in all. The return of captured ordnance shows 391 guns of different calibres, 5,316 muskets, 15 regimental colors, 33,346 rounds of small-arms ammunition, 8,394 round shot, 376 barrels of powder-besides grape and case shot, cartridges, etc., by the thousand.

${ }^{1}$ See foot-note, p. 207.

2 Afterward Earl of Moira and Governor-General of India. 
Lincoln's losses during the siege were 92 killed and 146 wounded; those of Clinton were 76 killed and 179 wounded. ${ }^{1}$

It was the greatest disaster sustained by the American army during the war-or, in fact, at any time; for on no other occasion (except at Harper's Ferry) have 5,000 men of the United States laid down their arms to an enemy. ${ }^{2}$

Lincoln was sent North on parole and immediately asked for a court of inquiry. ${ }^{1}$ But it was never held. Washington was at first disposed to think that Lincoln should have retreated North as soon as the Arbuthnot ships crossed the bar; but when he learned all the circumstances he held Lincoln blameless. ${ }^{1}$ The latter was Nov. 7 soon exchanged, resumed his military duties under Washington's direction, rendered excellent service for a year and was then appointed to the newly created office 1781 of secretary of war, ${ }^{3}$ filling that office until after the oct. 30 treaty of peace had been signed. In fact, serious as was the disaster, there is but little ground for criticism of Lincoln and much for commendation. The idea of re1780 treating was fully discussed in two councils; at the second April 21 of these, a large number of citizens broke in and declared April 26 that "if he attempted to withdraw the troops and leave the citizens, they would cut up his boats and open the gates to the enemy." The greater part of his force was militia and armed citizens; his Continentals were from the Southern States, and disposed to render allegiance to State rather than Continental authority. ${ }^{4}$ The command-

1 See foot-note, p. 207.

2 The surrender of 11,000 men under General White, near Harper's Ferry, on Sept. 15, 1862 was, in view of the magnitude of the struggle then in progress, comparatively unimportant.

3 Jour. Cong., III, 471, 683; Sparks, VII, 102.

${ }^{4}$ Moultrie's Memoirs, II, 97. 
1780 ing general was the only Northern man in the army. If he had ordered a retreat his orders would not have been obeyed, and there would have been dissension on the part of the civil authorities which would have probably carried the State back to its British allegiance. The prudent course of Lincoln preserved its adhesion to the United States.

On strictly military grounds a retreat was out of the question. Clinton had 12,500 soldiers well equipped in every particular. Had Lincoln crossed the Cooper River with his 2,000 ill-equipped Continentals and attempted the long march-without adequate transportation-to join Washington in New Jersey, he would probably have been overwhelmed and destroyed before he reached the Santee. In place of that he made a sturdy defence-remarkably so, in view of the slender resources at his disposal-and in so doing he delayed the conquest of South Carolina for at least two months.

Having taken Charleston, Clinton sent out detachments to occupy various points in the interior of the State. One of them under Tarleton, a most energetic cavalry leader, overtook, near the North Carolina boundary, the $3 \mathrm{~d}$ Virginia Regiment, about 300 men under Colonel Buford.

Action at the Waxhaws, May 29

June 5 which was marching from Virginia to Charleston. The engagement was short but destructive, the Americans losing 113 killed, 150 wounded and 53 prisoners; while Tarleton's losses were only 9 killed and 12 wounded. ${ }^{1}$

Believing that the State was now fully conquered, Clinton returned to New York, taking with him about one-third of his troops, ${ }^{2}$ and leaving with Cornwallis,

${ }^{1}$ Dawson, 582-585; Tarleton, 30; Stedman, II, 193.

2 Ante, p. 164; Sparks, V, 544. 
who hereafter commanded in the South, 6 British, 1 1780 Hessian, and 6 Provincial regiments - in all 8,345 men. The main body was at Charleston, but there were strong Return of, detachments at Savannah and Augusta in Georgia; and there was a chain of posts in South Carolina, from NinetySix on the West, through Rocky Mount, Camden and Cheraw, to Georgetown on the coast. ${ }^{1}$ The intense heat Disposition of British Troops After the Surrender of precluded active operations, and it was Cornwallis's intention to rest his troops during the summer, and as soon as the crops were gathered, and he could have the aid of the tory militia, to march northward and conquer North Carolina and Virginia. ${ }^{2}$

Active operations had now been in progress in the South continuously (except as interrupted by the summer heat) for about eighteen months. Savannah and Charleston, the two principal cities, had been captured; Georgia and South Carolina had been conquered and were everywhere under British control; the authority of the United States was not recognized nor were there any Continental soldiers-except prisoners of war-in any part of either State. Large numbers of the citizens had returned to the British allegiance; a greater number, however, adhered to the United States. Each side furnished its militia and they fought each other furiously; in one rough-andtumble encounter with clubbed muskets, about 400 men on a side, more than one-third of the combatants were killed and wounded; in another of a similar character, with about 800 men on each side, the tory losses were fully fifty per cent, those of the Americans not being recorded. $^{3}$ In a smart skirmish between 75 men under Colonel Bratton, one of Sumter's partisan chiefs, and a

Ramsour's Mill, N. C., June 20

Hanging Rock, S. C., Aug. 8

${ }^{1}$ Dawson, 592; Tarleton, 87; Stedman, 195; Lee, 78.

2 'Tarleton, 86.

${ }^{3}$ Dawson, 592-596, 601-603, 608-611.

Williamson's Plantation, S. C., July 12 
1780 scouting party from "Tarleton's Legion" with some of the tory militia-115 men in all-the latter was surprised and destroyed, only 12 men escaping. Soon after, SumRocky Mount, ter himself, with 600 men, assaulted a British fortified S. C., July 30 post but was repulsed with a loss of 13 men, the defenders (New York volunteers) losing 12. Two days later, at a point about 60 miles distant, in the north-west corner of South Carolina, Colonel Clarke, of Georgia, with Green spring, 196 men, met and defeated Captain Dunlap, who was S. C., Aug. 1 scouting with a detachment of 210 men-dragoons and mounted riflemen. The losses on each side were about

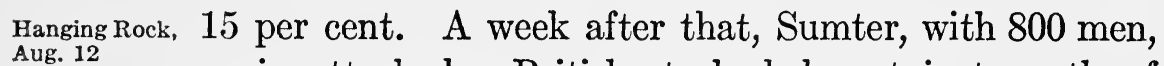
again attacked a British stockaded post just north of Camden. He was again unsuccessful and was forced to retreat, but only after a severe fight lasting nearly four hours, in which he had inflicted on the enemy a loss of about 130 men. $^{1}$

These partisan encounters were soon succeeded by events of a more serious character. Four months preApril 3 viously Washington had ordered the Continental line of Maryland and Delaware with a regiment of artillery and 12 guns to proceed to Charleston. Baron de Kalb, who had come from France with Lafayette, was assigned to the command. ${ }^{2}$ The force numbered 2,000 men, and the transfer of such a body for a distance of nearly 800 miles

De Kalb Marches to the South April 16 May 3 June 6 June 20 was a serious matter. The troops started from Morristown and marched to Head of Elk, where the infantry embarked on boats and proceeded through Chesapeake Bay and James River to Petersburg, where it was joined by the artillery which had gone overland. Here De Kalb learned of the surrender of Charleston. He continued his march, however, and crossing the border of North Carolina

${ }^{1}$ Dawson, 604-605. ${ }^{2}$ Sparks, VII, 7, 15. 
finally came into the theatre of operations and encamped 1780 on Deep River, about 50 miles north of the British post July 6 of Cheraw. He had called on the governors of Virginia and North Carolina for reinforcements of militia and for supplies of all kinds and transportation. But he received almost nothing; and, in fact, the States had little or nothing to give. More than once on their march the troops were in danger of starvation. ${ }^{1}$

The news of the fall of Charleston had reached Wash- June 1 ington, through his secret service in New York, ${ }^{2}$ earlier Gates Apthan it did De Kalb, and he had at once informed Congress. That body, without consulting Washington, appointed Gates to command the Southern army. ${ }^{3}$ Six pointed to Command the Southern weeks later Gates arrived at De Kalb's camp and took July 25 command.

De Kalb was an experienced soldier, and he had carefully studied the situation and formed a definite, careful plan of operations. It was submitted to Gates, with the approval of all the senior officers. ${ }^{4}$ But Gates declined to consider it and forthwith issued an order for the July 26 army to march immediately against Camden, the principal British post. This march of about 120 miles was accomplished in about two weeks, and in the course of it Gates was joined by 1,200 North Carolina militia under Caswell and by a few small detachments from the North. ${ }^{5}$

His movements were not unknown to Rawdon, who commanded at Camden. He called in his outlying detachments, reported the facts to Cornwallis and urged

1 Kapp's Kalb, 195-199.

2 Sparks, VII, 69.

s Jour. Cong., III, 465.

Army,

June 13

'Kapp's Kalb, 206-209; narrative of Williams, Johnson, I, 486.

5 Dawson, 612-619; Tarleton, 102-153; Stedman, 204-218; Lee, 94103; Kapp's Kalb, 220-238. The official reports are given at length in Tarleton. 
1780 him to come in person with reinforcements from Charleston. Cornwallis did so, and arrived at Camden three days before the battle. ${ }^{1}$

The situation was then as follows: Gates was at Rugely's Mills, 13 miles north of Camden, with a force which he imagined numbered 7,000 men, but in reality, as his adjutant-general informed him on the following morning, numbered 3,052 present fit for duty. They consisted of the Continentals of Maryland and Delaware, the militia of North Carolina and Virginia, 8 pieces of artillery, Armand's Legion and Porterfield's Light Infantry. The militia had been recently assembled and had never been in action or received any military training. There were no less than 13 general officers present, the greater part of them belonging to the militia. With this force Gates intended to attack the British post at Camden, of which he had no adequate knowledge, either by reconnoissance or otherwise. He seems to have thought that he could repeat the brilliant capture of Stony Point, and his order for a night march was in some degree copied from Wayne's famous order. In the afternoon before the march he issued to his men a full ration of corn-meal and fresh meat, and, having no rum, he distributed (from the hospital stores just arrived from Virginia) a gill of molasses per man. ${ }^{2}$ The food was hastily and badly cooked, and, washed down with molasses, it was more powerful than a compound cathartic. The men were in great distress during the night march and when the battle began were in an enfeebled, weak condition. ${ }^{3}$

Opposed to Gates, the force under Cornwallis should have numbered about 4,000 ; but the intense heat of

\footnotetext{
${ }^{1}$ See foot-note 5, p. 215. ${ }^{2}$ See foot-note 5, p. 215.

${ }^{3}$ Narrative of Colonel Otho Williams, Johnson, I, 494.
} 
summer had produced a good deal of sickness; more than 1780 800 were in the hospital, and, including the reinforcements which Cornwallis brought from Charleston, the morning report showed only 122 officers and 2,117 men fit for duty. About half the force was well-seasoned regulars, 23d, 33d and 71st Regiments; there were two tory regiments raised in New York, the Volunteers of Ireland and the British Legion, who were almost as good as regulars, and two regiments of Carolina militia. Cornwallis (like Gates) believed that the American army numbered 7,000 men. Nevertheless, he determined to attack them, relying upon the superior discipline and greater experience of his troops. ${ }^{1}$

Both armies, therefore, moved out at 10 o'clock at night, Aug. 15 each intending to surprise the other. About 2 o'clock in Aug. 16 the morning the advance guards came in contact at a point 9 miles north of Camden, where the road after crossing Saunder's Creek passes through an open forest of pines about a mile wide, flanked on each side by an impassable marsh. Armand's Legion, at the first fire, was thrown back on the main body in some confusion. But Cornwallis did not pursue, as he did not wish to risk the uncertainties and accidents of a night engagement. $\mathrm{He}$ leisurely deployed his force, the light infantry, 23d and 63d Regiments on the right, Irish Volunteers, Legion and North Carolina Regiment on the left, 71st in reserve and Tarleton's cavalry in the rear; and when the deployment was completed he waited for daylight. Gates also deployed in similar manner, 2d Maryland and Delaware on the right, North Carolina and Virginia militia on the left and 1st Maryland in reserve. The distance between the lines was about 200 yards. ${ }^{1}$

${ }^{1}$ See foot-note 5, p. 215. 
At daylight Cornwallis began the action by a vigorous attack from his right. ${ }^{1}$ The British regulars struck the Carolina and Virginia militia; the latter, in their weakened condition, due to the improper diet which Gates had prescribed, without any experience of battle and commanded by untrained officers, threw away their arms and fled. ${ }^{1}$ Armand's foreign legion went with them, and they broke through the left flank of the 1st Maryland, throwing that brigade into confusion, and, sweeping Gates with them, carried him off the field so that he was not again heard from for several days. But the Marylanders restored order in their ranks, made a partial change of front to the left, arrested the British advance and, on the right, under the gallant leadership of De Kalb, took the offensive. Rawdon's Irishmen made a stout defence, and there was fierce fighting in the woods for nearly an hour. Then De Kalb fell, mortally wounded; the $23 \mathrm{~d}$ and $33 \mathrm{~d}$ Regiments turned the left flank of the Maryland brigades; and Cornwallis, perceiving that there was no cavalry opposed to him (Armand having fled), sent Tarleton with the cavalry of his legion still farther around their flank and in their rear. The whole line then gave way, and the retreat was soon a rout. ${ }^{1}$

The American force was destroyed. It lost all its artillery, all its baggage, all its supplies and nearly all its muskets and ammunition. ${ }^{1}$ The militia scattered in every direction and in small groups worked their way home; the Delaware regiment was almost annihilated; the remnants of the 6 Maryland regiments, about 700 men in all, came together at Hillsborough about ten days after the battle. ${ }^{1}$ Gates covered the 60 miles to Char${ }^{1}$ See foot-note 5, p. 215. 

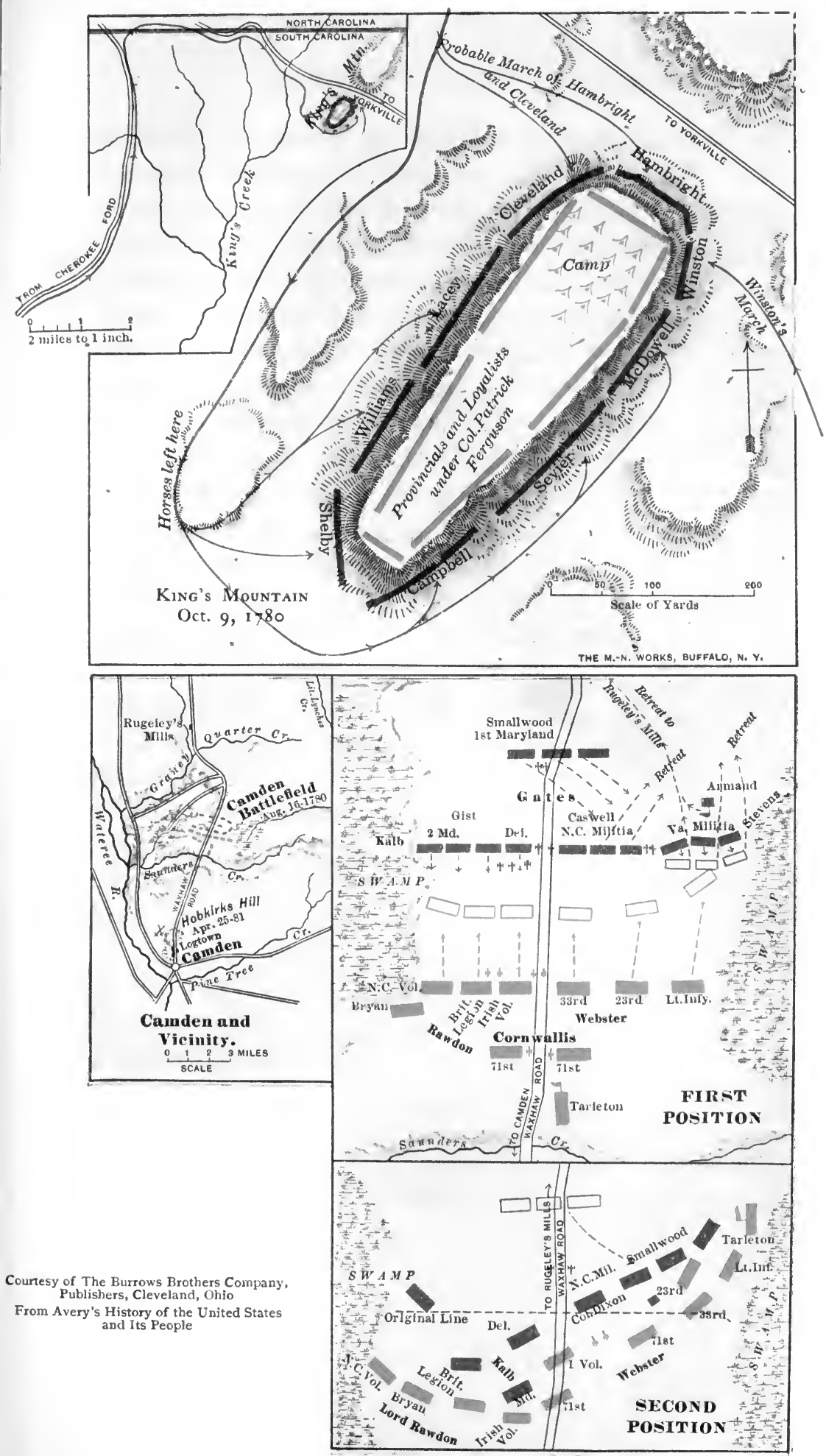

Campen

Aug. 16, 1780 


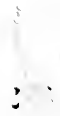

: 
lotte on the day of the battle, and in the next 48 hours another 100 miles to Hillsborough.

Cornwallis lost 68 killed, 245 wounded and 11 missing. ${ }^{1}$

Gates's army was thus destroyed; but Sumter and his partisans were still intact a few miles away. On the day aug. 15 before the battle Gates had sent him a reinforcement of 400 men, and on the day of the battle Sumter had intercepted and captured a considerable amount of supplies Aug. 16 and their escort which were coming up from Charleston and had nearly reached Camden. ${ }^{2}$ Hearing of Gates's defeat, Sumter began his retreat northward to his home country in the Catawba settlements. Tarleton went after him in hot pursuit, surprised him in his camp and destroyed him. Sumter himself escaped without hat, coat or boots; of his men, 150 were killed or wounded, 300 taken prisoners and the rest dispersed. The prisoners and supplies which Sumter had taken two days before were recaptured. Tarleton's loss was only 6 killed and 9 wounded. ${ }^{1}$

1 Dawson, 623. 


\section{CHAPTER VII}

\section{BRITISH DEFEAT AT THE SOUTH}

1780

Greene Appointed to Command the Southern Army

Oct. 22

THE conquest of the South seemed now to be complete. The only armed force of the Americans south of New Jersey was the remnants of Gates's army, about 700 in number, which were assembling at Hillsborough, in the northern part of North Carolina. Nevertheless, Congress did not despair. As usual when disasters came thickly it turned to Washington. Having itself chosen the three commanders, Howe, Lincoln and Gates, under whom Savannah and Charleston, Georgia and the two Carolinas had been lost, it now called upon Washington to select a commander for the Southern army. ${ }^{1}$ Washington selected Greene, ${ }^{2}$ who, in the language of John Fiske, "in every campaign since the beginning of the war had been Washington's right arm; and for indefatigable industry, for strength and breadth of intelligence, and for unselfish devotion to the public service, he was scarcely inferior to the commander-in-chief." ${ }^{3}$

Greene received his orders ${ }^{4}$ and letters from Washington while in command at West Point after Arnold's treason, and in accordance with his instructions proceeded immediately to Philadelphia for conference with Congress. Steuben was sent with him, ${ }^{5}$ to be second in

${ }^{1}$ Jour. Cong., III, 534.

${ }^{3}$ Fiske, American Revolution, II, 250.

${ }^{5}$ Fiske, II, 251.
'Sparks, VII, 257.

- Sparks, VII, 271, 272. 
command, and to be president of the court which Greene 1780 was ordered to convene to inquire into Gates's conduct.

Congress approved and ratified Washington's selection oct. 30 and adopted resolutions conferring upon Greene extraordinary powers. His army was to consist of all the Con- Oct. 3 tinental regiments raised or to be raised from Delaware oct. 21 to Georgia, inclusive (the number of such regiments having been fixed by previous resolutions at 24 , with an authorized strength of 36 officers and 681 men each); he was to organize and employ his army as he should judge most proper, subject to the control of the commanderin-chief, whose control at a distance of 800 miles, with no railroads or telegraph, was merely nominal; he was to have all the powers heretofore conferred upon Gates in regard to appointments and promotions, and in addition was to have the power ${ }^{1}$ of making exchanges of prisoners, which hitherto had been conferred only upon Washington; the legislatures and governors of the six States above named were "earnestly recommended" to "afford every assistance and support, in men, clothing, money, arms, intrenching tools, provisions and other aids and supplies"; and the heads of the several staff departments were "directed to furnish" on his order "such articles as, upon inquiry, he shall find cannot be obtained in the Southern Department." 2 In short, every power that Congress could put on paper was given to him. He was to carry on the Revolution in the distant South and regain the conquered States.

Had Congress been in position to make good its resolutions, Greene's task would have been an easy one. But the 24 regiments of the Southern States, from Delaware to Georgia, with an authorized strength of 17,000

1 Jour. Cong., III, 538, 540, 541.

${ }^{2}$ Ibid., III, 541. 
1780 men, had no existence, except in the remnants of Gates's army at Hillsborough. That of Georgia had never been raised; those of the two Carolinas and most of those of Virginia had been captured at Charleston.

Greene undertook the task in a hopeful if not confident spirit. ${ }^{1}$ He left an agent at Philadelphia to see that supplies were sent to him in case Congress had any; and on his way south he left Steuben in Virginia to organize all the troops that Governor Jefferson would call out, both Continental and militia, and forward them to the South. Several of the best officers in the army made applications to go with him-Steuben, ${ }^{2}$ Lafayette, ${ }^{3}$ Henry Lee ${ }^{3}$ (father of Robert E. Lee) and John Laurens. ${ }^{3}$ Washington had different plans for Lafayette, but the others were sent. ${ }^{4}$ On his arrival at the South, Greene soon gained the loyal and hearty support of the famous partisan leaders-Morgan, Marion, Sumter, Pickens and William Washington.

Dec. 4

When Greene took command at Charlotte, the paper strength of his "army" was 2,307, of whom 1,482 were present, and not quite 800 were equipped and fit for duty. ${ }^{5}$ He succeeded, with Steuben's efficient help, in increasing this, within three months, to 4,441 present for duty, of whom 1,651 were Continentals, although most of them were new levies who had never been in battle. ${ }^{\circ}$ It never again reached that number. This was the force, aided by the partisans of Sumter and others, which varied in

${ }^{1}$ G. W. Greene, III, 35; letter to Congress.

2 Kapp, Steuben; Sparks, VII, 316, 361, 404.

${ }^{3}$ Sparks, VII, 316; Sparks, Letters, III, 140.

${ }^{4}$ Laurens on arriving at Philadelphia was selected for the special mission to France (ante, p. 178), but he joined Greene as soon as he returned.

${ }^{5}$ Greene to Lafayette, G. W. Greene, III, 70; Gordon, IV, 27.

${ }^{\circ} \mathrm{G}$. W. Greene, III, 190; Gordon, IV, 54. 
numbers at various times, from nothing to perhaps a 1780 maximum of 2,000, with which Greene reconquered the South. The returns in the British Record Office show that in 1781 and 1782 the British force in the Carolinas and Georgia varied from a minimum of 8,141 to a maximum of $10,859^{1}$-effective, fit for duty, exclusive of officers and non-commissioned officers. About threefourths of them were regulars, British and Hessians, and the rest were tory regiments from New York and New Jersey, which had seen four years' service, and were fully as well organized as and infinitely better equipped and supplied than the few Continentals in the Southern army.

In the interval between the battle of Camden and the Aug. 16 date when Greene assumed command, Cornwallis had not been idle. He had marched, unopposed, into North Carolina as far as Charlotte; and Clinton had sent 3,000 men under Leslie from New York to the Chesapeake, ${ }^{2}$ Oct. 16 there to act under Cornwallis's orders and either effect a junction with him as he marched north, or to create a diversion in his favor and prevent the sending of reinforcements to the South. These plans miscarried; for, soon after Cornwallis reached Charlotte and before Leslie had Clinton sends reinforcements sailed from New York, a force of backwoodsmen, between 900 and 1,500 strong, who lived in the mountains from Virginia to Georgia, suddenly appeared almost as if they had sprung out of the ground, and surrounded a party of regulars and tory militia, about 1,100 in number, on King's Mountain. This force was commanded by Major Ferguson, of the 71st Regiment, a gallant and skilful officer. He had been posted in the foot-hills of the Alleghanies, on Cornwallis's left flank, about thirty miles from Mountain ${ }^{1}$ Sparks, V, 542.

${ }^{2}$ Tarleton, 170, 199; Sparks, VII, 269. 
1780 Charlotte. He was to keep down the patriot militia in that neighborhood. Hearing of the approach of Colonel Williams and the others, he took a defensive position on the top of King's Mountain, a wooded hill just north of the boundary between North and South Carolina. Here he was surrounded by the mountaineers about 4 o'clock Oct. 7

Oct. 14 on an autumn afternoon. The battle was not very scientific, but it was effective. Dismounting from their horses, these frontiersmen climbed the hill on all sides, using their hunting rifles with great effect. Ferguson made a gallant defence. Three times he beat them back, using the bayonet. After an hour of hard fighting Ferguson was killed and his men surrendered. He had lost 224 killed and 163 wounded; 716 were taken prisoners. On the American side 28 were killed (including Williams) and 60 wounded.' The Americans dispersed almost as quickly as they had gathered.

The news of this extraordinary action spread fast in all directions; it brought out the militia of North Carolina and the new levies in Virginia; it carried discouragement

Results of the Battle of King's Mountain to the tories in both Carolinas. It took place on the edge of Mechlenberg County, where the hostility to Great Britain was fierce, and whence a declaration of independence had been launched a full year before that of Philadelphia. Surrounded by such a hostile population, disappointed in the hopes he had formed that North Carolina would rally to his support as he advanced and stunned by the blow at King's Mountain, where 121 of his regulars and nearly 1,000 of his militia had been destroyed, Cornwallis not only halted his invasion but retreated, in some haste, to South Carolina. He marched back 90 miles, and took station at Winnsboro, between Camden

${ }^{1}$ Dawson, 628-632; Tarleton, 164, 192-196. 
and Ninety-Six. Here he fell ill of a fever which incapac1780 itated him for several weeks. During this time Rawdon oct. 24 was in command, and he received a letter from Clinton advising him that Leslie had sailed for the Chesapeake and was to act under Cornwallis's orders. Rawdon at once wrote to Leslie ${ }^{1}$ requesting him to come by water to Leslie Sent to Reinforce the Cape Fear River in North Carolina. Leslie was delayed by gales and did not reach the Cape Fear River in less than six weeks. On arriving there he found instruc- Dec. 14 tions from Cornwallis to come to Charleston, where he 1781 arrived safely, and thence marched to Camden. ${ }^{2}$ He Jan. 4 brought with him 2,500 men-a.brigade of the Guards, the regiment of Bose, the Hessian Yagers and some Provincials. This carried Cornwallis's strength, according to Clinton, to 11,306 effective, ${ }^{3}$ exclusive of officers. The number of posts which he felt obliged to occupy made it impossible to take more than 4,000 men when he resumed his march into North Carolina.

Until Leslie arrived at Camden, nearly three months after King's Mountain, Cornwallis remained idle at Winnsboro. The partisan troops, however, were incesAction at Fish Dam Ford, santly on the move-Sumter in the Catawba district and Marion, "the Swamp Fox," on the lower Pedee. The latter penetrated to within a few miles of Georgetown but was driven back into the swamps. Sumter was attacked, ${ }^{4}$ at a point on the Broad River about 25 miles north-west of Winnsboro, but held his own. Then the ever restless Tarleton was recalled from his pursuit of Marion in the low country and sent to destroy Sumter. Action at Tarleton was worsted, losing more than 100 men; the Nov. 20

${ }^{1}$ Sparks, VII, 347.

2 Tarleton, 184, 243.

${ }^{3}$ Clinton-Cornwallis, I, 282.

4 Dawson, 633; Lee, 112; Tarleton, 173, 200. 
Greene Takes the Offensive

Dec. 16

success, however, was counterbalanced by the fact that Sumter was wounded ${ }^{1}$ and was not able to take the field again for several weeks.

While Cornwallis was at Winnsboro waiting for Leslie, Greene had taken the offensive. He was so inferior in numbers to Cornwallis that battle was out of the question until he could raise and equip a larger force; his only plan now was to carry on a partisan warfare, threatening Cornwallis's flanks, breaking up his communications and intercepting his supplies. ${ }^{2}$ In pursuance of this plan he divided his force, small as it was, and sent Morgan with about 600 men-Maryland line, Virginia militia and the remnants of the 1st and 3d Dragoons under William Washington-to cross the Catawba, join Sumter and other partisans and move South, threatening Ninety-Six and Augusta. ${ }^{3}$ The rest of his force, about 1,100 in number under Huger, was sent to the Pedee and took position at Cheraw, where Rawdon had maintained a post prior to the battle of Camden. In this position they supported Marion, threatened Camden and were nearer to Charleston than Cornwallis was at Winnsboro. Greene accompanied Huger's column.

It was a risky movement, for the two detachments were 140 miles apart, with Cornwallis between them, and a good chance for him to beat them in detail. If Cornwallis attempted this Greene expected by a rapid retreat to unite the two detachments in North Carolina, ${ }^{4}$ and he sent his chief engineer, Kosciusko, and his quartermaster, Carrington, back to reconnoitre the fords

${ }^{1}$ Dawson, 635-637; Lee, 114; Tarleton, 173-180.

${ }^{2}$ G. W. Greene, III, 130; Greene to Washington, Sparks, Letters, III, $189,214,217,225$.

${ }^{3}$ Johnson, I, 346.

- Greene to Varnum, Johnson, I, 350. 


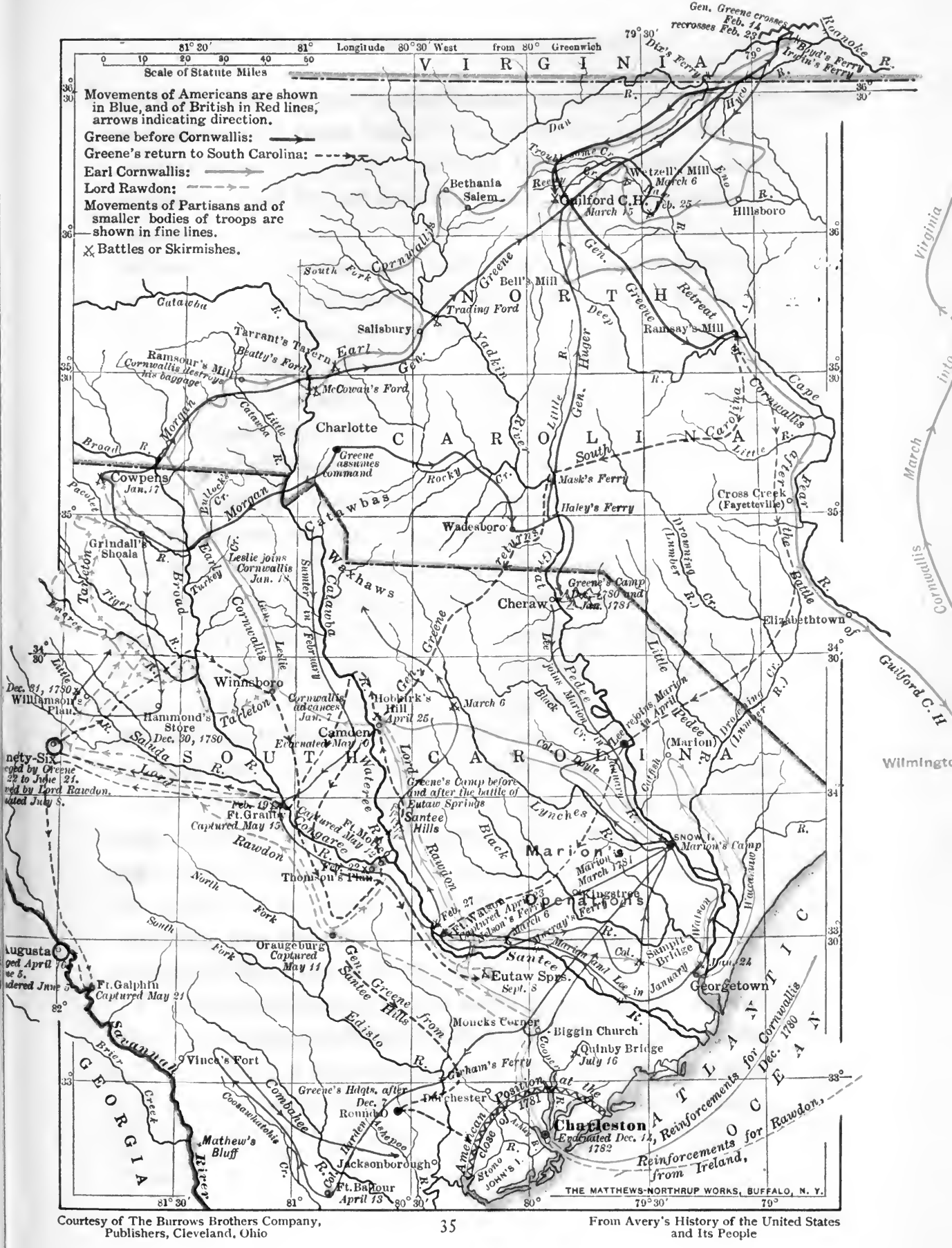

CAMPAIgN of $178 \mathrm{I}$ 
on the various rivers, ${ }^{1}$ collect boats and obtain wagons for transporting them from one river to the next. While at Cheraw, Lee's Legion arrived from the North and was sent to join Marion and make another demonstration against Georgetown.

Meanwhile, Clinton, at New York, was supporting 1781 Cornwallis by every means in his power, in the hope of Jan. 12 making a complete job at the South. As soon as he heard that Leslie had been ordered from the Chesapeake to Charleston, he sent another expedition to the Chesapeake $-1,600$ men under Benedict Arnold, now a brigadier in the British service. Arnold arrived at Hampton 1780 Roads, went up the river to Jamestown, marched 800 men to Richmond and burned the town. His instructions were to cut Greene's communications and destroy his supplies at Petersburg; but Steuben rallied the Virginia militia and Arnold retreated down the James River to Portsmouth and waited for reinforcements from New York. This movement into Virginia led Washington to send Lafayette thither with 1,200 men. ${ }^{3}$ The entire en- Feb. 20 ergies of both sides were thus concentrated on the South. The successive reinforcements of the British were all placed under Cornwallis's orders, and those of the Americans under Greene; but the distance was so great and the means of communication so slow that the Virginia campaign was carried on by the local commanders independent of their nominal chiefs.

To return to Cornwallis: the audacity of Greene's movements-dividing his inferior force-had the desired effect. It led Cornwallis to scatter his forces. Had Cornwallis

${ }^{1}$ The military importance of these rivers, which played so important a part in Sherman's campaign in 1865 as well as in Greene's campaign of 1781 , is evident from a glance at the map.

${ }^{2}$ Sparks, VII, 348.

${ }^{3}$ Ibid., VII, 417-423. 
1780 quickly concentrated and attacked first one and then the other of Greene's detachments, he might have destroyed both. Instead of this he sent Tarleton to attack Morgan; directed Leslie to march to Camden to protect that post against a possible attack by Huger; and kept his main body at Winnsboro, which was 70 miles from Tarleton on the one side and separated by a deep river (Wateree) from Leslie on the other side. Instead of his beating Greene in detail, Greene's right wing under Morgan destroyed Cornwallis's detachment under Tarleton.

Tarleton crossed the Broad River, and moving rapidly up its western branches he came in contact with Morgan at the Cowpens-an enclosure for cattle just south of the line between North and South Carolina and about 20 miles west of King's Mountain. Morgan had about 1,000 men, the force with which he left Charlotte having been increased by about 400 militia. Tarleton's command numbered about 1,000 men-British Legion and parts of the 7th, 16th and 71st Infantry and 17th Dragoons. ${ }^{1}$ He reconnoitred Morgan's position and found that he was posted in an open wood, his flanks unprotected and the Broad River at his back. Tarleton was of opinion that the position was very advantageous for him and disadvantageous for Morgan. He anticipated an easy victory.

Morgan, however, thoroughly understood the troops under his orders, and as a commander of light troops he was unexcelled-perhaps unrivalled. He posted his force in three lines: in front, 150 expert riflemen; then about 315 militia, many of whom had served in the Continental line; in rear of these, on a slight eminence, the Maryland regulars who had survived Camden, and more militia, about 430 in all; behind this eminence the cav-

${ }^{1}$ Tarleton, 250; Johnson, 367. 
alry, 125 strong, under William Washington. The men 1781 had slept well, had eaten a good breakfast and were in fine spirits. Morgan had harangued them in satisfactory fashion, and had instructed them to reserve their fire until the enemy was within 50 yards, then to take careful aim at those who wore epaulets, and while continuing their fire to retire to the second line of militia, which was under command of Pickens. After firing two rounds, carefully aimed, Pickens's line was to retire to the left of the regulars. All these orders were carried out with remarkable exactness.

Tarleton began his march during the night and made such slow progress that five hours elapsed before he came in sight of the first line of the militia. He then deployed; light infantry and legion infantry to the right, 7 th Infantry to the left with the 71st in reserve behind its left flank, legion cavalry in the second line and a troop of dragoons on each flank. In this order they advanced, without firing. At 50 yards the militia delivered their Battle of the
Cowpens fire with murderous accuracy and fell back as ordered; the British returned the fire and continued their advance, the 71st being brought into line on the left of the 7 th. An attempt was made by the dragoons on the right to turn Morgan's left flank, but William Washington with his cavalry came out from behind the eminence where he had been under cover and drove them back. The British continued to advance, and soon came on the main linethe Marylanders. These received them with very deliberate fire, delivered kneeling, and aimed low. The 71st outflanked the American right, and to meet this an order was given to the companies on the right to change front. This was not well executed, and the whole line began to retreat. Tarleton thought the day was won and sent

Jan. 17 3 A. $\mathbf{~ s .}$ 8 A. M. 
1781 orders to the legion cavalry to come up on the left and charge. Before this could be done Morgan gave an order, "Face about and fire once more." This was performed with great coolness, and simultaneously the militia which had retreated as ordered at the beginning was just finishing a complete circle of the whole battle-ground and coming up on the American right. The British were staggered at first and then ran. They were experienced troops, most of whom had served throughout the war and been in many battles. A panic set in quite similar to that which seized the Americans at Germantown, and their officers could not stop them. More than half the command surrendered and the rest fled. William Washington charged in pursuit, but Tarleton managed to collect 14 officers and 40 horsemen and checked the pursuit sufficiently to enable him to escape and rejoin Cornwallis.

The battle lasted less than an hour. Tarleton lost 100 killed, 229 wounded and 600 prisoners not wounded, about 85 per cent of his entire command. The firing at the epaulets was very effective, for 39 of his officers were killed or wounded. Morgan's loss was only 12 killed and 60 wounded. $^{1}$

This was one of the most interesting battles of the whole war. It shows what can be done with militia provided they are good marksmen and are commanded by competent officers who understand them. Morgan, Pickens, William Washington and Clarke, of Georgia, were all experts in their respective lines.

It had been suggested by Tarleton two weeks before the battle that while he advanced against Morgan's front the main body under Cornwallis should simultaneously advance to King's Mountain to cut off his retreat.

${ }^{1}$ Dawson, 646-653; Tarleton, 214, 250; Johnson, 370-384. 
Cornwallis replied: "You have . . . understood my 1781 intentions perfectly." " But Cornwallis did not do his Jan. 5 part. He seems to have been nervous about his right flank, which was threatened by Huger and the main body of Greene's little army on the Pedee. Cornwallis moved a few miles from Camden and then waited a week until Leslie had crossed the Wateree. He then slowly Jan. 14 moved northward, but on the day of the battle instead of being at King's Mountain in Morgan's rear he was 25 miles to the south. Had he been in rear of Morgan, he might have destroyed him or driven him westward into the mountains, notwithstanding Morgan's victory over Tarleton, for Cornwallis outnumbered Morgan nearly four to one. ${ }^{1}$

Morgan had no illusions as to his position after the battle. He buried the dead, left the wounded of both Morgan Retreats to the sides under a flag of truce and, picking up his captured cannon, ammunition, 800 muskets and prisoners, before noon he began his retreat and crossed the Broad River. He was so encumbered with prisoners and captured stores that his progress was slow, but it was fast enough to keep ahead of Cornwallis; and at the end of a week he had marched nearly 90 miles and had passed the Catawba. The next day Cornwallis arrived at Ramsour's Mill (now Jan. 24 Lincolnton) on the Little Catawba, 20 miles to the rear. Jan. 25

It was a week before the news of Morgan's victory Jan. 24 reached Greene, on the Pedee. He also learned that Morgan was retreating and Cornwallis advancing, and he saw that the thing to do was to unite Huger and Morgan as quickly as possible. He therefore called in Lee, who Jan. 25 was scouting on the sea-coast near Georgetown, and ordered Huger to march to Salisbury; and personally he

$$
1 \text { Tarleton, } 246 .
$$


1781

Greene Joins Morgan, Jan. 30

Jan. 26 Jan. 27

Retreat to the Dam

Jan. 29

Jan. 29 rode across the country, 125 miles, with only an aide and three orderlies, and joined Morgan on the Catawba. ${ }^{1}$

Cornwallis was on the opposite side of the river, delayed in crossing by a sudden rise of the river. When he had arrived at Ramsour's Mill and realized that Morgan was 20 miles ahead of him, he made up his mind to divest himself of everything that could impede rapid movements. He spent two days in burning up all his tents, baggage and extra clothing and supplies, keeping only his ammunition, hospital stores and such rations as could be carried on the person. The destruction of the rum, then the choicest article on the ration list, seemed to the officers to be an extraordinary act of self-abnegation. He also destroyed all his wagons except a few which were to be used for the sick and wounded, and he mounted some of his infantry, on the horses thus made available.

Then began a retreat ${ }^{2}$ (on the American side), one of the most memorable in the annals of war ${ }^{3}$; the numbers were small but the stake was great, and there was abundant military skill on both sides.

Leaving Ramsour's Mill (Lincolnton), Cornwallis arrived at the Catawba on the afternoon of the second day. It was too late for a crossing, and during the night came the rise in the river due to a winter's rain. Cornwallis had no boats and it was necessary to wait for two days for the river to subside sufficiently to be fordable. During this interval Greene arrived and immediately made

1 Johnson, 394-403.

${ }^{2}$ Gordon, IV, 36-45; G. W. Greene, III, 151-175; Johnson, 403432; Greene to Washington, Sparks, Letters, III, 225, 233; Tarleton, 218-229, 249-264; Stedman, 325, 333.

3 " Every measure of the Americans, during their march from the Catawba to Virginia, was judiciously designed and vigorously executed." (Tarleton, 229.) 


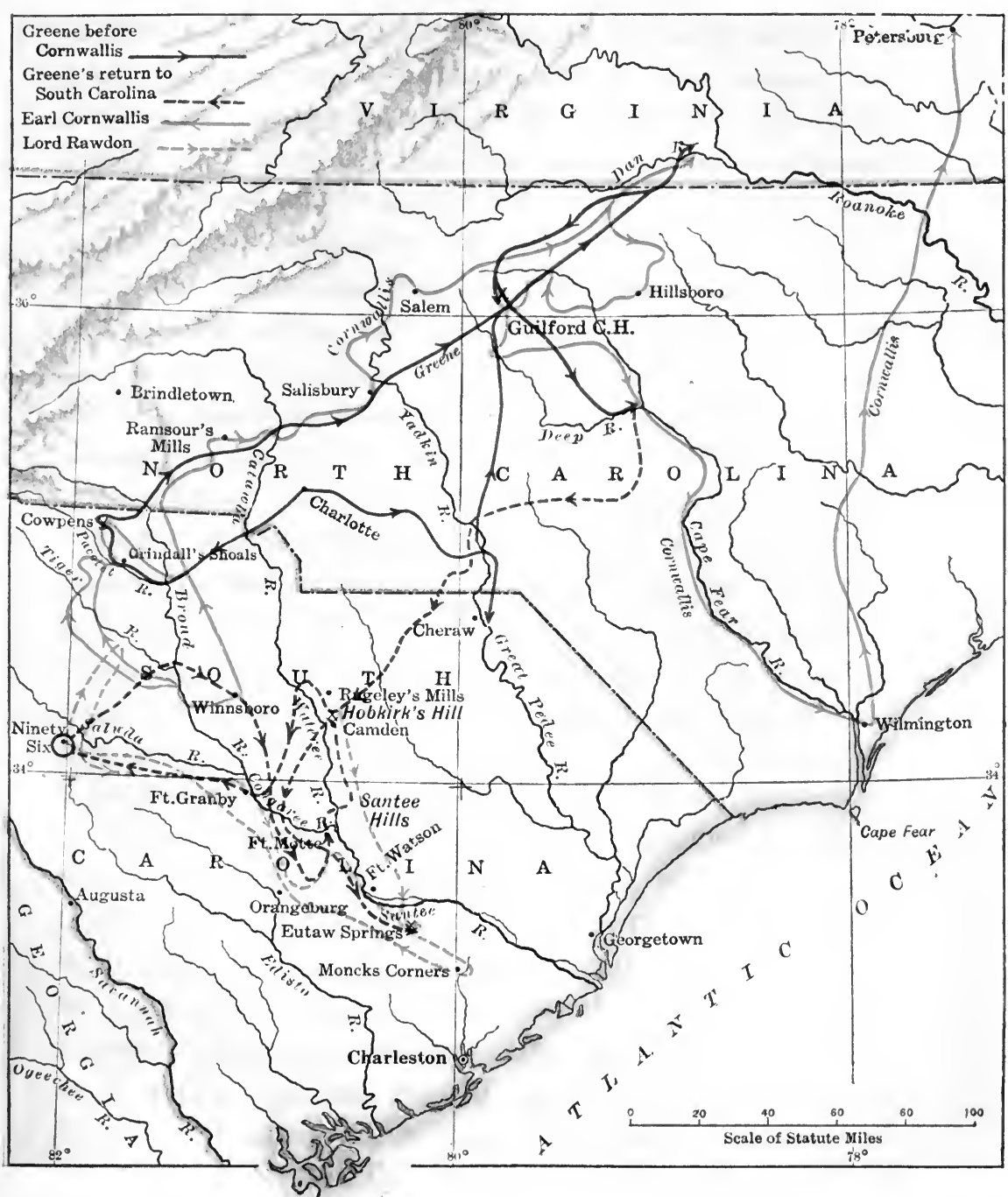
Courtesy of The Burrows Brothers Company,
Publishers, Cleveland, Ohio

$3 \hat{3}$

From Avery's HIstory of the United States

\section{Retreat to the Dan Jan.-Feb., 1781}




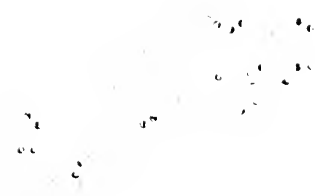


the following dispositions: Pickens with the militia was to take the Cowpens prisoners through the mountains to Charlottesville, where the Saratoga prisoners were now kept; Morgan was to retreat at once to the Yadkin; the fords on the Catawba were to be watched by 300 North Carolina militia under Davidson, who had just joined the army; Huger was to hasten his march to Salisbury.

The next day the river had fallen sufficiently to be ford- Feb. 1 able, and Cornwallis forced a passage at two fords, dispersing the militia, but only after they had inflicted on Passage of the Catawba him a loss of 4 killed and 36 wounded and their own leader, Davidson, had been killed. He pushed forward during the afternoon, and one of Tarleton's scouting parties came near capturing Greene, who had remained with the militia until they dispersed and had then ridden rapidly toward Salisbury. He stopped to pass the night Feb. 1 at Carr's house, and from there wrote to Huger countermanding his orders of the previous day in so far as to require him to keep on the east side of the Yadkin and not to attempt to reach Salisbury. It was evident that a junction with Morgan there was impossible.

Morgan, having a day's start, easily reached the Yad- Feb. 2 kin before Cornwallis could come up with him. The Feb. 3 river was swollen with rains, but Carrington was there with the boats, on which the foot troops and supplies were ferried across, while the mounted men swam their horses. Greene joined him during the crossing, and just as it was completed toward sundown the advance of Cornwallis's army came up. They had no boats and could not cross. All they could do was to bring up their artillery and bombard the American bivouac; the troops were easily put under shelter, and the only harm done was to shatter the hut in which Greene was writing his 
1781 despatches-one of which directed Huger to leave the Yadkin and march for Guilford.

Passage of the Yadkin, Feb. 8

Feb. 8

Feb. 9

Feb. 11

Cornwallis was thus forced to move twenty-five miles up the Yadkin where the fords were more shallow, and this he did during the next few days. His intention was to put himself between Greene and the fords on the upper Dan, believing that Greene could not cross the lower Dan and that he could thus force him to fight at a disadvantage. As this movement developed Greene, with Morgan, retired slowly to Guilford (near Greensborough) and there was joined by the rest of his army under Huger and Lee.

His army being reunited, Greene was disposed to accept battle. He carefully selected a good position at Guilford. Unless he could rally the militia he was still too weak in numbers to expect success. His efforts to bring out the militia were fruitless; moreover, every day's retreat brought him nearer to Steuben and reinforcements in Virginia, and carried Cornwallis farther from his base. A council of war decided unanimously against a battle. ${ }^{1}$

Greene therefore determined to continue the retreat and put himself behind the Dan. Carrington had already collected the boats on that river in the vicinity of Boyd's Ferry; Kosciusko was sent there to throw up trenches to defend the crossing; a body of 700 picked men under Feb. 14 Williams was sent to get in front of Cornwallis and retard his advance as much as possible. With the main body and the supplies Greene left Guilford, and three days later crossed the Dan at Boyd's Ferry, about 10 miles above the junction of the Dan with the Roanoke, and about 30 miles below the present city of Danville. The following day Williams, who had carried on a continuous

${ }^{1}$ Johnson, II, 425. 
series of skirmishes with Tarleton for the last four days, also safely crossed the river, his men in the boats and the horses swimming as at the Yadkin. Cornwallis's own Feb. 15 letter accurately describes the movement: "I tried by Greene a most rapid march to strike a blow either at Greene Crosses the (Huger) or at Morgan before they got over the Dan, but Virginia could not effect it."

What was now to be done? Cornwallis was 230 miles from his base; he had no boats to cross the Dan or the Roanoke on Greene's left flank. If he attempted to cross higher up Greene would meet him at whatever point he selected, and the crossing would be difficult if not impossible. Should it succeed Greene would retreat into Virginia and soon effect a junction with Steuben, and then Cornwallis would be outnumbered. Cornwallis therefore decided to march back into North Carolina, occupy Hillsborough, where the Provincial legislature had lately been in session, "raise the royal standard" and try to gather the tory militia. His army soon reached Hillsborough. It was exhausted with its long march, during which it had lost about 250 men; and the lack of supplies which had been burned up at Ramsour's Mill four weeks ago was now keenly felt.

Greene's army was also exhausted with the long march in the dead of winter, over roads alternately frozen and deep in mud, with a succession of snow-storms and rains, which inflicted a greater hardship on his men than on the British, because they were insufficiently clad, had neither tents nor blankets and many of them were barefooted. His army was intact and by no means despondent. Reinforcements from Steuben speedily began to arrive.

In the face of extraordinary difficulties, Steuben had raised and equipped 400 Continentals, and the militia of 
1781 the southern counties of Virginia at last realized their

Greene

Receives Reinforcements

Feb. 18

Feb. 23

Destruction of Colonel Pyle's Tories,

Feb. 25

Feb. 26

danger and began to assemble. Pickens had returned from taking the prisoners to Virginia and was now back on the Catawba rallying the militia which had dispersed at the crossing of that river. The Governor of North Carolina was using every effort to bring out the militia in other parts of the State. From all of these sources Greene's army, which numbered only 1,430 when it crossed the Dan, was increased within the next three weeks to 1,715 Continentals and a force of militia which has been variously estimated at from 2,800 to 3,900 men. His total force at the battle of Guilford was between 4,500 and 5,700 men. ${ }^{1}$ His own returns, two days before the battle, give the number as $4,444 .^{2}$

He moved in pursuit of Cornwallis before the reinforcements began to arrive. The day after Cornwallis left the Dan to march to Hillsborough Greene sent Williams across the river, and he followed with the main body a few days later. In scouting around Hillsborough Lee (whose legion was part of Williams's command) fell in with the first body of tory militia which responded to Cornwallis's proclamation. It numbered 300 men, was commanded by Colonel Pyle, was marching from Guilford to Hillsborough and was about midway between the two hamlets. By a stratagem Lee got in immediate contact with it before his identity was discovered; when the firing began Lee's men cut the tories to pieces, 90 of them being killed, nearly all the rest wounded and only a few escaping. ${ }^{3}$ Lee did not lose a man. The news of this encounter travelled fast and it put a decided damper on rallying to "the royal standard." The next day Cornwallis left

${ }^{1}$ Schenck, 310-312.

${ }^{2}$ Gordon, IV, 54 .

'Dawson, 658-660; Lee, 154-157; Tarleton, 231-233. 
Hillsborough and marched westward to meet Greene. 1781 The two armies came in touch on the Haw River. Both March 2 were anxious for battle, but Greene wanted to postpone it until his reinforcements arrived. Constant manœuvring followed for ten days, and there was a smart skirmish ${ }^{1}$ in which about 50 men were lost on each side. Finally the Action at Wetzell's Mill, reinforcements arrived, and as soon as he could organize them Greene marched to Guilford, intending to accept March 10 battle on the ground which he had carefully selected during his retreat. His force numbered, as already stated, between 4,500 and 5,700 men; but of these less than 500 had ever been in battle. Cornwallis's return gave 2,253 March 14 fit for duty, exclusive of officers. Every man (except the North Carolina regiment which was left with the baggage on the day of the battle) was a veteran regular who had been in most of the battles at the North as well as at Savannah, Charleston and Camden. Relying on the superior quality of his troops, as at Camden, Cornwallis did not hesitate to attack.

The dispositions of the troops on both sides were quite similar to those at the Cowpens. Greene had, in fact, recently received a letter from Morgan ${ }^{2}$ giving his advice in regard to the handling of the militia. ${ }^{3}$ Greene had the highest regard for Morgan and adopted his suggestions. He posted ${ }^{4}$ the North Carolina militia in a line across the Salisbury road about a mile from Guilford, with expert riflemen on each flank, the Delaware battalion and Lynch's Virginians on the right and the legion infantry and Campbell's Virginians on the left. About 300 yards

\footnotetext{
${ }^{1}$ Dawson, 661-663.

${ }^{2}$ Morgan was obliged by ill health to leave Greene's army in February. He joined Washington just before the surrender at Yorktown.

${ }^{3}$ Schenck, 321.

4 Greene's Report, Tarleton, 312-317.
} 
behind them was a line of Virginia militia, with William Washington's cavalry on their right and Lee's on their left. The third line was about 550 yards in rear of the second and was composed of the Continentals, 2 Virginia regiments on the right and 2 Maryland regiments on the left, posted on a slight eminence some distance in front of the Court-House. The only fault in these dispositions seems to have been in having the lines too far apart, about twice the distance they were at the Cowpens. Doubtless this was made necessary by the nature of the ground, which was heavily wooded, with occasional clearings of a few acres for cultivation. There was one such clearing in front of the main line and another in front of the advanced line, and it was thought that the North Carolina militia, posted in the woods behind this latter clearing and their flanks held by expert riflemen, would make a good resistance although they had never before been under fire.

Cornwallis had been encamped for two days on the Salisbury road, about twelve miles south-west of Guilford. Hearing of Greene's movement to that point, he left the North Carolina regiment with the baggage and with his 2,000 regulars broke camp at daylight and marched toward Guilford. After marching eight miles his advance under Tarleton came in contact with Lee and a skirmish ensued, Lee falling back to the main body and taking post on the left flank as above stated. About noon Cornwallis came in sight of the American lines and at once deployed: Leslie's brigade (71st and Bose) to the right, Webster's brigade (23d and 33d) and Yager's to the left, O'Hara's brigade(Guards) in reserve, two pieces of artillery on the road in centre and Tarleton's cavalry in the rear. ${ }^{1}$

${ }^{1}$ Cornwallis's Report, Tarleton, 303-310. 

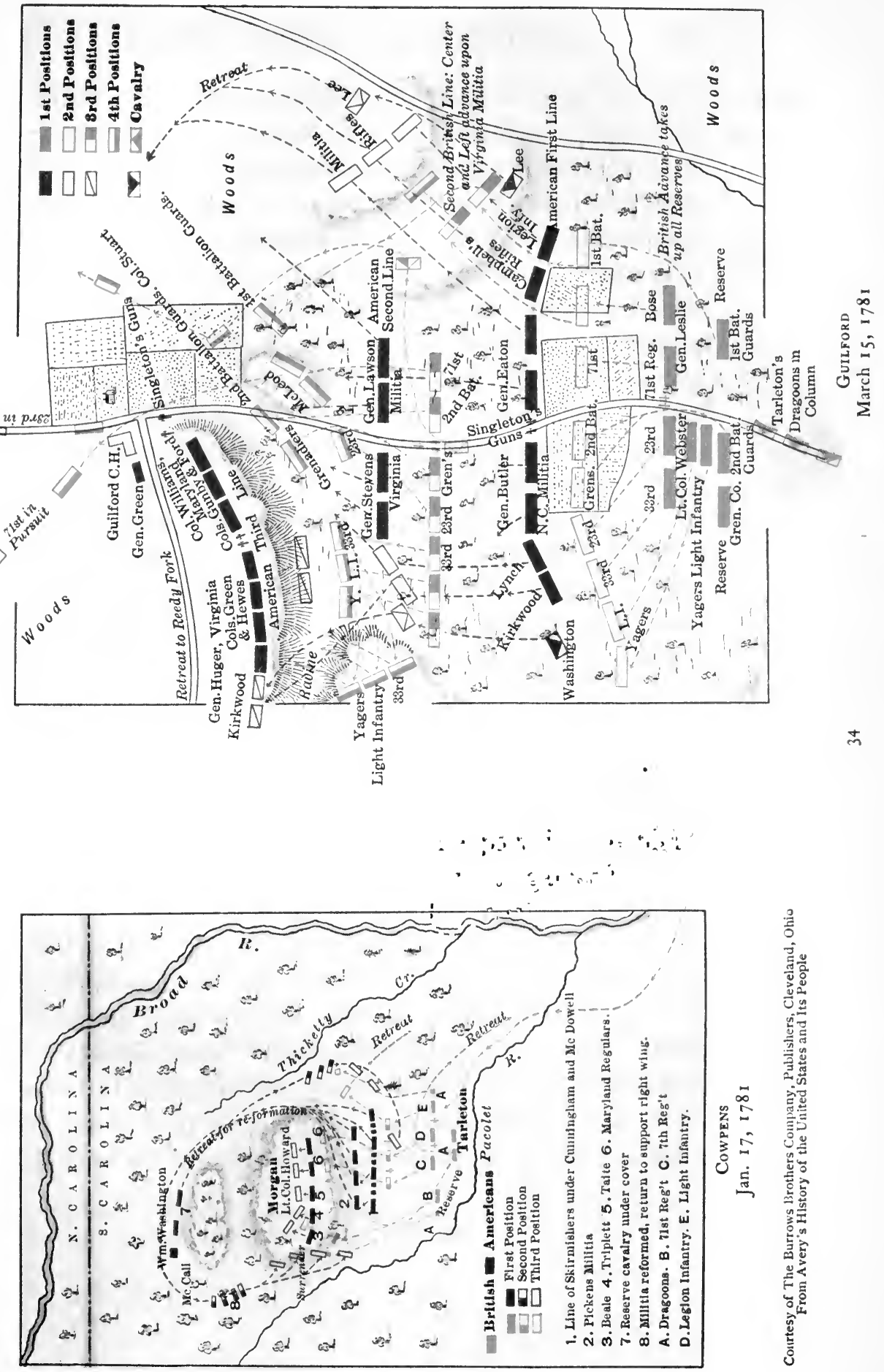


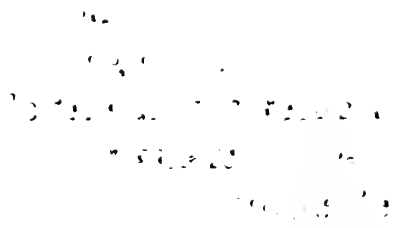


The battle ${ }^{1}$ opened with a cannonade from the two 1781 3-pounders which lasted twenty minutes. Then the 1.30 p. s. whole line advanced with admirable steadiness across the first clearing. The air was sharp and frosty and the British bayonets glistened in the sun of a cloudless day. The North Carolina militia had no bayonets. They were armed with hunting-rifles and powder-horns. It took three minutes to load. They delivered their first fire at 150 yards. When they had reloaded the Highlanders were within 40 yards; the militia fired their second round, leaning their rifles on the rail-fence at the edge of the clearing. Both rounds were carefully aimed and were effective. But still the British line came on. It is claimed-and also disputed - that Greene had given the North Carolina militia the same order that Morgan gave at Cowpens, to fire two rounds and then retire to the next line. Whether they had this order or not they retired. not to the second line, but far beyond the battle-ground. They ran through the intervals of the Virginia militia and past its left flank, and most of them were not again heard of.

The flanking parties did not take part in the flight, and Leslie's brigade wheeled to the right against Lee and Campbell and Webster's to the left against Kirkwood and Lynch; O'Hara's brigade moved forward into the gap thus created. Kirkwood and Lynch fell back slowly, contesting their ground, and took post on the right of the Continentals; William Washington's cavalry withdrew to the rear of the Continentals; Lee and Campbell did not yield at first, and it was only after the 1st Battalion of the Guards had been brought up on the right

${ }^{1}$ Tarleton, 269-279; Stedman, II, 337-347; Johnson, II, 1-22; Lee, 170-180; Dawson, 663-670; Schenck, 292-387. 
1781 of the Bose regiment that they were forced back up the slope of a hill just behind their first position. The action continued here, quite separate and apart from the main battle, for nearly two hours, and in the course of it Cornwallis personally led the Guards battalion and had his horse shot under him.

March 15th,

The North Carolinians having broken and run, O'Hara's Guilford brigade advanced through the woods, with Webster on its left and the 71st on its right, and fell upon the Virginia militia-the second line. But they made a good defence, until their right flank was enveloped by the British left, when it gave way; and soon after Stevens, who commanded the left brigade, was badly wounded. Then the whole line gave way and retreated past the left of the Continentals.

Within half an hour after the battle opened the militia, whether their numbers were 2,800 or 3,800 , were all gone except the gallant riflemen from Virginia under Lynch and Campbell, many of whom were old soldiers, but whose numbers did not exceed 200 men. The North Carolinians had lost 11 and the Virginians 46, killed and wounded, and had inflicted probably an equal loss on their opponents. The hard fighting of the day was yet to come, and the numbers were about equal-2,000 on each side.

The British troops continued their advance through the woods and came to the second clearing. Three separate and somewhat disjointed attacks were made across this and against the four Continental regiments posted on the rising ground in the woods on the opposite side. Two of them were repulsed-the first by Webster's brigade, against the centre of the line between the Virginia and Maryland brigades. He was driven back with heavy loss, Webster himself being mortally wounded and his 
brigade forced back across the clearing and separated 1781 from O'Hara. The second was by two battalions of the Guards under O'Hara. They struck the left flank-the 2d Maryland, a new regiment-and it fled almost without firing a shot. Then the 1st Maryland wheeled to the Battle of Guilford left and took them in flank, and they were driven back in great confusion, one battalion losing nearly half its strength and O'Hara being wounded. They were pursued by the 1st Maryland and by William Washington's cavalry. Colonel Stewart of the Guards was killed, and their retreat was only checked by Cornwallis in person, who brought the two 3-pounders along the road to the edge of the clearing and ordered them to fire grape over the heads of his own men, many of whom were wounded by it.

If at this moment Greene had followed up his suc- March 15, cess by a vigorous attack with the three regiments which $3.30 \mathrm{P} . \mathrm{M}$. now remained to him, he might have defeated Cornwallis. The attack might have failed, and if so he would have lost his whole army and the war in the South would have ended-for there were no more reinforcements to come from the North. He had previously made up his mind never to risk the total destruction of his army, and he abided by this determination. He therefore reformed his men in their first position on the wooded hill; and Cornwallis brought up the 71st and the battalion of the Guards which had been fighting against Lee and Campbell on the extreme right, reformed his lines and prepared for a final assault with the seven battalions which he now had. As he began to move forward Greene decided to save his army while it was still in his power to do so. He placed the 1st Virginia, which had not been engaged, in position to cover his retreat, and retired in good order. Corn- 
1781 wallis followed him only a short distance, and before morning Greene had taken a good defensive position behind the Haw River, about ten miles from the battle-

March 16 March 17

Cornwallis Retreats to Wilmington

March 18 March 28 field. He had lost 78 killed and 183 wounded; when the returns were made up, 1,046 of the militia were missing; the others had straggled into camp. He had inflicted upon Cornwallis a loss of 93 killed, 413 wounded and 26 missing, nearly 30 per cent of his strength. ${ }^{1}$

The retreat to the Dan and the battle of Guilford were to the South what the retreat through New Jersey and the battles of Trenton and Princeton were to the North. They turned the tide; and each attracted equal attention in Europe. Greene lost the battle but won the campaign, and the first step toward Yorktown was taken. Cornwallis's losses were so great and his situation so precarious at such a distance from his base that a retreat was imperative. The only question was in what direction he should go. The distance to Camden was about 160 miles. To return there was to acknowledge the total failure of his campaign. The distance to Wilmington was about 200 miles. There he would have the support of the British ships; and possibly he might draw Greene after him, and after he had refitted his army engage him in battle again and meanwhile the posts in South Carolina would be safe. ${ }^{2}$

He determined to retreat as far as Cross Creek (Fayetteville) where he had ordered supplies to be sent from Wilmington. Giving his men two days' rest and abandoning his wounded, he began his march. Greene instantly started in pursuit. He came up with Cornwallis's rear at Ramsay's Mill, on Deep River, but did not feel

${ }^{1}$ Dawson, 669, 670.

${ }^{2}$ Tarleton, 278, 322-327; Stedman, II, 350-353. 
strong enough to attack him. Cornwallis then went on 1781 unmolested to Cross Creek, and finding no supplies there april 7 continued his retreat to Wilmington. ${ }^{1}$

Greene did not follow him beyond Deep River. Cornwallis being out of the way, he decided to march to South Carolina and endeavor to regain that State. ${ }^{2}$

He remained at Ramsay's Mills a week, reorganizing March 29 his army and perfecting his plans. The Virginia and April 5 North Carolina militia had been called out for six weeks and their time was up; they had been with him just twentythree days, and they had been of real service for they had enabled him to fight the battle of Guilford even though they had failed at the critical moment. He released them all with thanks and sent them home. His army was then reduced to the four Continental regiments-1st and 2d Virginia, 1st and 2d Maryland, Lee's Legion and William Washington's dragoons-in all about 1,450 men. Under a curious order of the "Council Extraordinary" which then administered so much of the Provincial government as existed in North Carolina, all of the six weeks' militia who had fled from Guilford were "sentenced to twelve months' duty as Continentals." ${ }^{3}$ An effort was made to round them up, and later a few hundred of them joined Greene and did good service, as did other skeleton regiments which were raised as speedily as possible in North Carolina. The force with which Greene began his march into South Carolina was less than 1,500 men.

He designed to aid these to the utmost by utilizing fully the partisan corps under Sumter, Marion and Pickens. While Greene was not as successful as Morgan in getting the most out of the militia on the battle-field, he was

${ }^{1}$ Tarleton, 278, 322-327; Stedman, II, 350-353.

${ }^{2}$ Greene, Letters, Johnson, II, 37-40. ${ }^{3}$ Schenck, 394. 
1781 far more successful than any other commander at the South in securing the co-operation of these irregular leaders, who abhorred discipline, considered obedience as synonymous with servility and made it a practice to submit their plans to their followers for approval before putting them into execution. Notwithstanding these eccentricities they rendered valuable service.

Sumter was now on the Broad River, recovered from his wound and recruiting his men; Marion was hiding in the Pedee swamps, but ready to emerge when conditions were favorable; Pickens was on his familiar ground in western South Carolina. Greene communicated with all of them, requesting their assistance, and they cheerfully gave it-sometimes according to Greene's plans and sometimes according to their own.

On the British side, Rawdon had been left in command when Cornwallis marched North. He was at Camden, whose garrison was 1,400 men, of whom 500 were at the moment detached in the hope of catching Marion. In addition to the two main posts of Charleston and Savannah, there were others at Augusta, Ninety-Six, Fort Granby, Orangeburg, Fort Motte, Fort Watson and Georgetown, whose garrisons varied from 120 to 630 men. Excluding Charleston and Savannah, Rawdon had about 3,500 effective men in the various other posts, and in the two States 8,141. ${ }^{1}$

Greene Marches to South

Carolina

With his 1,500 Continentals and such assistance as he could get from the partisan leaders and any militia that might join him, Greene set out to capture these posts and reconquer South Carolina. With the main body he marched to Camden; he kept Lee on his left flank, to give warning if Cornwallis should come toward South ${ }^{1}$ Sparks, V, 545. 
Carolina, and if not then to effect a junction with Marion 1781 and attack Fort Watson, below Camden; Sumter was requested to join the main body at Camden, and Pickens to advance against Ninety-Six on his right.

Greene marched to Camden, 140 miles in 14 days, of April 6-20 which 3 were spent in collecting boats to cross the Pedee. During this time Lee had joined Marion at a ferry lower april 14 down on the Pedee, and the two had proceeded to besiege Fort Watson, a stockaded post on the Santee about halfway between Camden and Charleston. After a siege of 8 days the place was captured ${ }^{1}$ by the expedient of cutting trees and erecting (during the night) a tower, from the top of which a plunging fire was delivered inside the stockade which rendered it untenable. Its garrison of 120 men was captured, with the loss to Marion and Lee of 2 killed and 4 wounded. They then moved to the High Hills of Santee in the hope of intercepting Colonel Watson, who with 500 men of the Camden garrison had been sent to catch Marion in the Pedee swamps and after a fruitless chase was now returning to his post. He managed to evade Marion and Lee and joined Rawdon at Camden, but not until after the battle had been fought.

Greene had approached Camden from the north and May 7 had hoped to surprise it, but the tories gave warning of april 20 his approach. Not having men enough either to assault or to surround and besiege it, he retired to a rising ground about two miles north of the village and took up a defensive position. The ground was wooded-like nearly all of the battle-grounds in the Southern campaign. Its right was protected by the Wateree, its left by a rivulet and swamp; the high-road from Camden to the Waxhaws passed through the centre. The troops were disposed as

${ }^{1}$ Dawson, 672; Lossing, II, 501. 
1781 follows: the 2 Virginia regiments on the right, the 2 Maryland on the left and 2 guns on the road between them; a body of North Carolina militia which had just joined were placed in the second line, thus reversing the dispositions made at the Cowpens and at Guilford. William Washington's cavalry was in rear of the left and the Delaware battalion was stationed as an outpost at the foot of the hill about 500 yards in advance of the main line. The men bivouacked in this order night and day, expecting an attack. Greene's strength, Lee's Legion being detached, was 1,174 Continentals and 248 North Carolina militia. ${ }^{1}$

Battle of Hobkirk's Hill, April 25

Rawdon decided to attack without waiting for Watson, as he feared that Marion and Lee might join Greene if he delayed. Marching out of his fortified village early in the morning, he circled to the right through the woods in order to approach the hill from the south-east where the slope was least steep. He had 1 regular regiment$63 \mathrm{~d}$-and 3 regiments of New York tories (Volunteers of Ireland, King's American and New York Volunteers), with a detachment of South Carolina tories and a few 10 A. м. dragoons. As he came in contact with the Delaware battalion he deployed with 3 regiments in the first line and moved forward to attack the hill.

Greene seems to have been overconfident, and instead of waiting to receive the attack in his chosen position on the crest of the wooded slope he took the offensive. Rawdon's front being narrow, he endeavored to envelop him on both flanks while he made a vigorous attack on his centre. Campbell with the 1st Virginia was to turn his right flank, Ford with the $2 \mathrm{~d}$ Maryland his left;

${ }^{1}$ Johnson, II, 72-95; Stedman, 356-362; Dawson, 680-684; G. W. Greene, III, 239-255. 

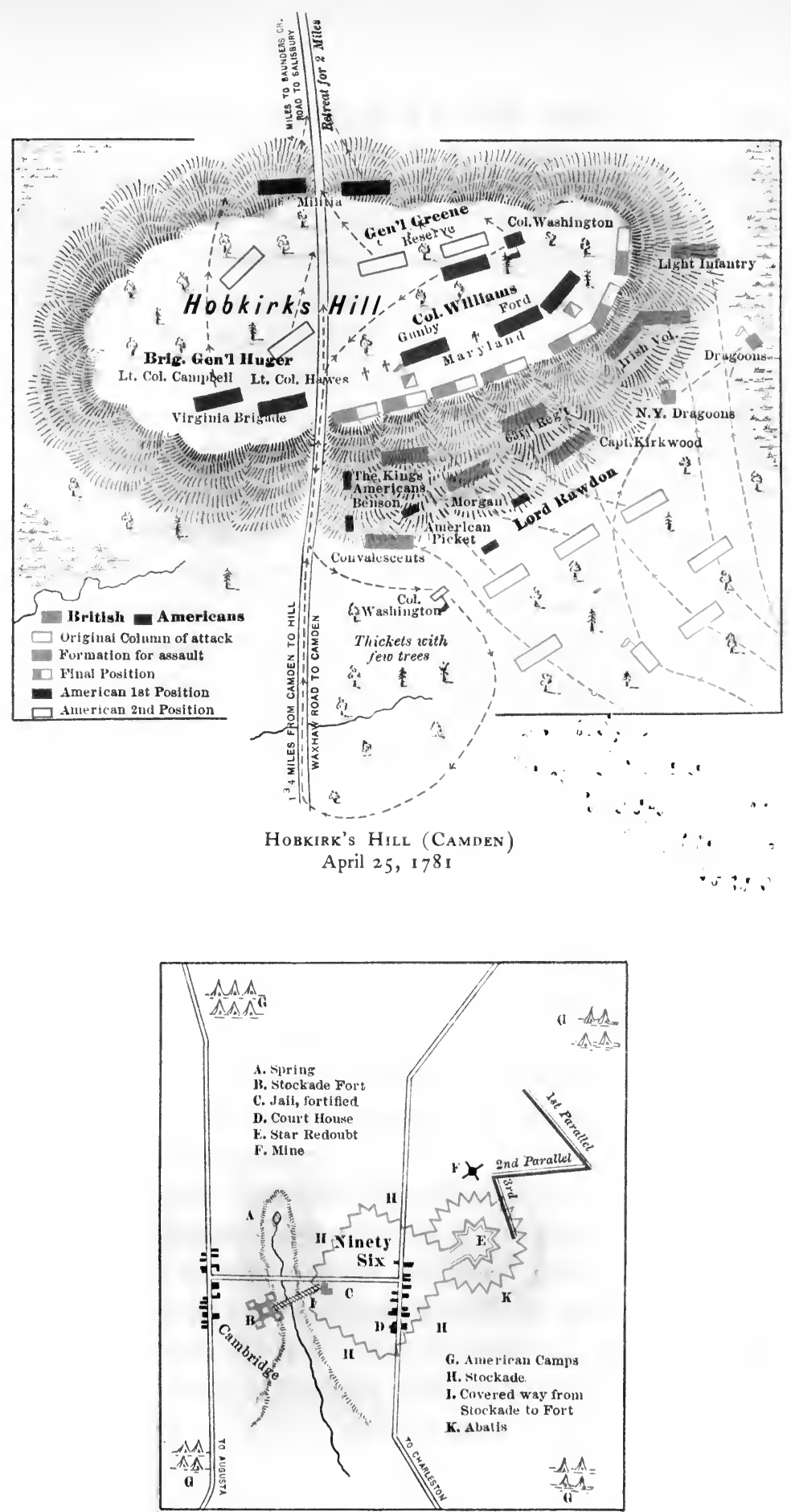

NinETY-Six

May 22-June 5, I 78 I 


$$
\begin{aligned}
& \therefore \because \ldots \\
& \cdots, \quad \therefore \because "= \\
& \therefore \quad \because \therefore \\
& \because . . \\
& \text { : }
\end{aligned}
$$


Gunby with the 1st Maryland and Hawes with the 2d 1781 Virginia were to charge with the bayonet against his centre; the artillery were to use grape; and William Washington with his cavalry was to sweep around his left flank and attack him in rear.

It was too ambitious a programme. Rawdon quickly extended his front by bringing up the Irish regiment, and in the sharp fighting which ensued Captain Beatty of the 1st Maryland was killed, his company began to retire and Gunby ordered the regiment to fall back to reform. In doing so this regiment-which had fought so gallantly at Camden, the Cowpens and Guilford, and in nearly every battle since Long Island-became demoralized and could not be rallied. Rawdon's men charged up the hill, and the $2 \mathrm{~d}$ Maryland, seeing the retreat of the 1st, and their colonel, Ford, being mortally wounded, also began to retreat; and this brought Rawdon on the left flank of the Virginia regiments. Greene saw that the day was lost and immediately withdrew the Virginia regiments and the artillery. His little force retreated five miles and took up another position, but Rawdon did not pursue. He returned within his lines at Camden that same afternoon.

Greene's losses were 19 killed, 115 wounded and 136 missing, and Rawdon's about the same, 258 killed, wounded and missing. ${ }^{1}$

Thus Greene lost his second battle, and he was somewhat disheartened, writing to Luzerne, the French minister (in a vain appeal for help from the French soldiers cooped up in Newport): "We fight, get beat, May 10 rise and fight again." ${ }^{2}$ As at Guilford, the ultimate advantages were all on his side; for Rawdon, unwill-

${ }^{2}$ Dawson, 684.

'See also Sparks, Letters, III, 299. 
1781 ing to risk a second engagement, soon retreated to Charleston. ${ }^{1}$

$\operatorname{May} 7$

May 10

Rawdon

Evacuates

Camden

May 24

Capture of Fort Motte

At the time of the battle, Pickens on the extreme right was approaching Ninety-Six; Marion and Lee on the left were at the Santee Hills, trying to intercept Watson on his return from Georgetown to Camden; and Sumter, instead of joining Greene as requested had started on an independent expedition against Fort Granby (Columbia). Watson managed to elude Marion and join Rawdon in Camden. Greene then sent Lee against Fort Granby, Marion against Fort Motte, 30 miles south of Camden, and with his main body retired 6 miles to Rugely's Mill. Rawdon was thus surrounded and every one of his posts threatened. Notwithstanding the reinforcement brought by Watson, he did not feel strong enough to attack Greene, and he decided that his only safety was in a retreat to Charleston. He therefore burned the stockades at Camden and such stores as he could not carry, and retreated to Monck's Corner, about 30 miles from Charleston.

While he was on his retreat Marion surrounded Fort Motte. ${ }^{2}$ This was a post, garrisoned by 150 men, at the point where the Congaree and Wateree Rivers unite to form the Santee. With Fort Watson, lower down on the Santee, it maintained the communications between Camden and Charleston. The post consisted of an old colonial mansion, in a commanding situation, which had been fortified. It was captured by the novel expedient of shooting arrows carrying firebrands against the dry shingles on the roof, by which the house was set on fire. The garrisoned soon surrendered. ${ }^{3}$

${ }^{1}$ Stedman, II, 361.

2 Dawson, 689-692;

G. W. Greene, III, 278.

${ }^{3}$ Lossing, II, 480. 
Lee then went on to Fort Granby, where Sumter had 1781 abandoned his attack in favor of a more promising expedition against Orangeburg, about thirty miles to the south. Capture of Orangeburg, Rawdon had already given orders for the evacuation of Orangeburg, but Sumter arrived before the order was executed, and with slight difficulty captured the garrison of 350 men. He then retraced his steps to Fort Granby and on his arrival was annoyed to find that Lee had arrived the day before and had compelled its surrender, with its garrison of 240 men. Sumter felt that Lee had stolen his glory and complained to Greene of Lee's conduct, stating that he considered it "for the good of the public to do it without regulars." 1 Greene replied that Lee had acted in accordance with his orders; whereupon Sumter sent in his resignation. Greene diplomatically persuaded him to withdraw it, and he afterward rendered excellent service, in co-operation with Lee, in the vicinity of Charleston. $^{2}$

All the interior posts in South Carolina were now capt- May 9 ured except Ninety-Six. As soon as Rawdon evacuated Camden, Greene marched rapidly toward Ninety-Six, sending Lee some North Carolina militia, who had just arrived, to join Pickens who had collected a considerable body of militia in the vicinity of Augusta. On his way May 21 Lee captured a large amount of supplies collected for distribution to the Indians at a point on the Savannah River, about twelve miles below Augusta. He then crossed the river and late on the same day joined Pickens on the west side of Augusta.

This village was defended by two stockaded forts, one in the village and the other about half a mile up the river. Its garrison numbered 630 men, under Lieutenant-Colonel 
1781 Browne. The garrison of the upper fort was composed of Georgia loyalists. They attempted to escape to the main fort and nearly half of them were killed by the Georgia militia of Colonel Clarke. The siege of the principal fort lasted fourteen days. Browne made a stiff defence. To the first summons to surrender he returned a spirited refusal. He made two vigorous sorties. The besiegers finally won by the same device as at Fort Watson-a wooden tower from which to deliver a plunging fire within the stockade. Browne was finally forced to yield, and signed articles of capitulation in which his garrison was definitely surrendered as "field prisoners of war." 1

Pickens and Lee hastened to join Greene, who had begun the siege of Ninety-Six. This place had been elaborately and somewhat curiously fortified with stockades and deep ditches. Its garrison numbered 550 men, a tory regiment from New York, another from New Jersey and some South Carolina loyalists-all commanded by Lieutenant-Colonel Cruger, of New York. He also made a spirited defence. Greene had only 984 men-prior to the arrival of Pickens and Lee-and it was impossible to surround the place. His engineer, Kosciusko, opened his first parallel at 70 yards. Cruger punished this "insult" the next morning by a vigorous sortie supported by the fire of three 3-pounders. The intrenching party was routed and lost most of their tools. Kosciusko then began a new first parallel at "a more respectful distance," 400 yards, and from this the besiegers gradually worked their way up to the ditch of the Star Fort. There were constant sorties; there were the same devices of a wooden tower for plunging fire and arrows carrying firebrands to set fire to the beleaguered buildings; the source of

${ }^{1}$ Dawson, 673, 679; G. W. Greene, 300-302; Stedman, II, 363. 
water supply was captured, and the besieged suffered terribly from thirst. ${ }^{1}$

While the siege was in progress reinforcements from June 3 Ireland arrived at Charleston, three full regiments, $3 \mathrm{~d}$, 19th and 30th, and a number of recruits for the Guards. Rawdon determined to march to the relief of Ninety-Six. Marion was operating near the coast, and hearing this news sent a courier to notify Greene, who in turn sent explicit instructions to Sumter and Marion to place themselves in front of Rawdon and retard his advance, as Williams and Lee had so skilfully done on the Dan. Rawdon managed to evade them, and was approaching with 1,800 infantry, 200 cavalry and a body of South Carolina loyalists. To conclude the siege before his arrival was impossible, and Greene determined on an assault. Campbell with picked detachments from the Virginia and Maryland regiments was to attack the Star Fort, and Lee with the legion infantry the redoubt; the rest of the command was to man the wooden tower and the trenches from which they were to concentrate their fire on the Star Fort. Axes were provided to cut down the abatis, fascines to fill up the ditch and long poles with hooks to pull down the sand-bags of the besiegers' trenches. At noon the assault began, preceded by an hour's cannonade from Greene's four guns. The storming parties rushed forward and gained the ditch. Then the besiegers poured into the ditch from the sally-port of the main stockade. A desperate hand-to-hand struggle resulted and the assailants were driven out. Lee was more successful and carried the redoubt, and was preparing to attack the village stockade from the rear. Greene, how- July 20

${ }^{1}$ Dawson, 692-697; Stedman, 364-373; G. W. Greene, 303-317; Johnson, II, 138-154. 
1781

June 21

ever, adhering to his resolution never to submit his little force to the risk of total destruction, decided not to renew the assault, but to raise the siege, and preceded by his wounded he moved across the Broad River in the direction of Charlotte.

He had again lost the battle, but won the campaign, for Ninety-Six was speedily evacuated and never again occupied by the British.

His losses during the siege were 57 killed, 70 wounded and 20 missing. Cruger lost 27 killed and 58 wounded. ${ }^{1}$ Rawdon arrived the following day after an exhausting march of 180 miles. As quickly as possible he started in pursuit of Greene, but finding that the latter had crossed the Broad he returned to Ninety-Six and made Evacuation of preparations for its evacuation. Leaving Cruger there Ninety-Six, July 3 to arrange for the departure of the numerous loyalists residing in the vicinity, Rawdon marched first to Fort July 14 Granby and then to Orangeburg, where he was joined by the $3 \mathrm{~d}$ Regiment, Lieutenant-Colonel Stewart, from Charleston, and soon after by Cruger, from Ninety-Six. This carried his strength to nearly twice that of Greene; and the latter decided on account of the intense heat to march his men to the high hills of Santee, about 30 miles below Camden, for a short but much-needed rest. July 20 Leaving Stewart in command in Orangeburg, Rawdon took 500 men and returned to Charleston, pursued by Sumter and Marion and Lee to within 5 miles of the city. Rawdon then left for England on leave of absence, but his ship was captured by de Grasse and he was carried a prisoner to Yorktown. Stewart followed Greene and went into camp facing him, with the Congaree between them. Greene's main body was on the Santee Hills; 
Sumter took station on his right near the site of Fort

Granby (Columbia), Marion (who had captured George- Capture of town while Greene was at Ninety-Six) on his left at Nel- Gune 20 son's Ferry on the lower Santee, and Pickens returned to his old recruiting-ground near Ninety-Six. ${ }^{1}$

It was not quite eight months since Greene had taken command at the South. At that time everything south of North Carolina was in the enemy's possession. Now they had lost all of Georgia except Savannah and all but a small portion of South Carolina. In the interval Greene's little army had marched 950 miles, fought 3 battles and a score of minor engagements, conducted 5 sieges, captured 9 posts and taken nearly 3,000 prisoners. His army had no organized commissariat or transport system, no tents or camp equipage, and only insufficient clothing. He had no base of supplies, but lived off the country which, although in the main friendly to him, was filled with a very substantial minority of intensely bitter loyalists. The enemy outnumbered him three to one, and was composed of the best British regulars and Hessians, the well-organized and veteran tory regiments of New York and New Jersey and a numerous body of local partisans, all well equipped and supplied, and supported by an ample military chest of ready money.

Battles were lost because the troops lacked training and that steadiness which only experience under fire will bring; but the campaigns were won by tireless marches skilfully planned and directed. These were carried on, with extraordinary fortitude on the part of the men, through the snows and cold rains of the winter and the fierce heat of a Southern summer.

${ }^{1}$ Stedman, II, 372-383; Johnson, II, 162-178. 
1781 Greene gave his little army six weeks' rest in the com-

Aug. 23

Greene

Resumes the Offensive

Aug. 28

Sept. 7

Sept. 8

8 A. M. paratively salubrious region of the Santee Hills. During that time he received some fresh levies from North Carolina (the Guilford runaways, "condemned" to twelve months, service as Continentals), carrying his strength to something over 2,000 men. He then resumed the offensive, and marched to attack Stewart.

It would have been difficult, if not impossible, to have forced a passage of the Santee; and Greene therefore made a circuit of about ninety miles, crossing the Wateree near Camden and the Congaree below Fort Granby (Columbia), and picking up the militia of Pickens and Henderson (formerly Sumter) on his march. Having thus crossed the rivers, he approached Stewart from the north-west, and the latter retired about forty miles to his depot of supplies at Eutaw Springs.

Greene slowly followed him, and a week later was joined by Marion on his return from a very successful raid on the Edisto near Charleston. The next day Greene moved forward in two columns, ready for deployment as soon as the enemy was encountered. He had 2,300 men of whom 1,254 were Continentals and the rest militia.

Stewart had an equal number, but all veterans; 6 regiments-3d, 63d, 64th, Grenadiers, New York Volunteers and New Jersey Volunteers. They were encamped in a clearing, on both sides of the main road, a few hundred yards from the Santee; and in rear of the camp was a substantial brick house and palisaded garden which played a very important part in the battle.

About four miles from the camp Lee's cavalry came in contact with a "rooting" party (sent out to dig sweetpotatoes) and its escort. There was a skirmish in which 


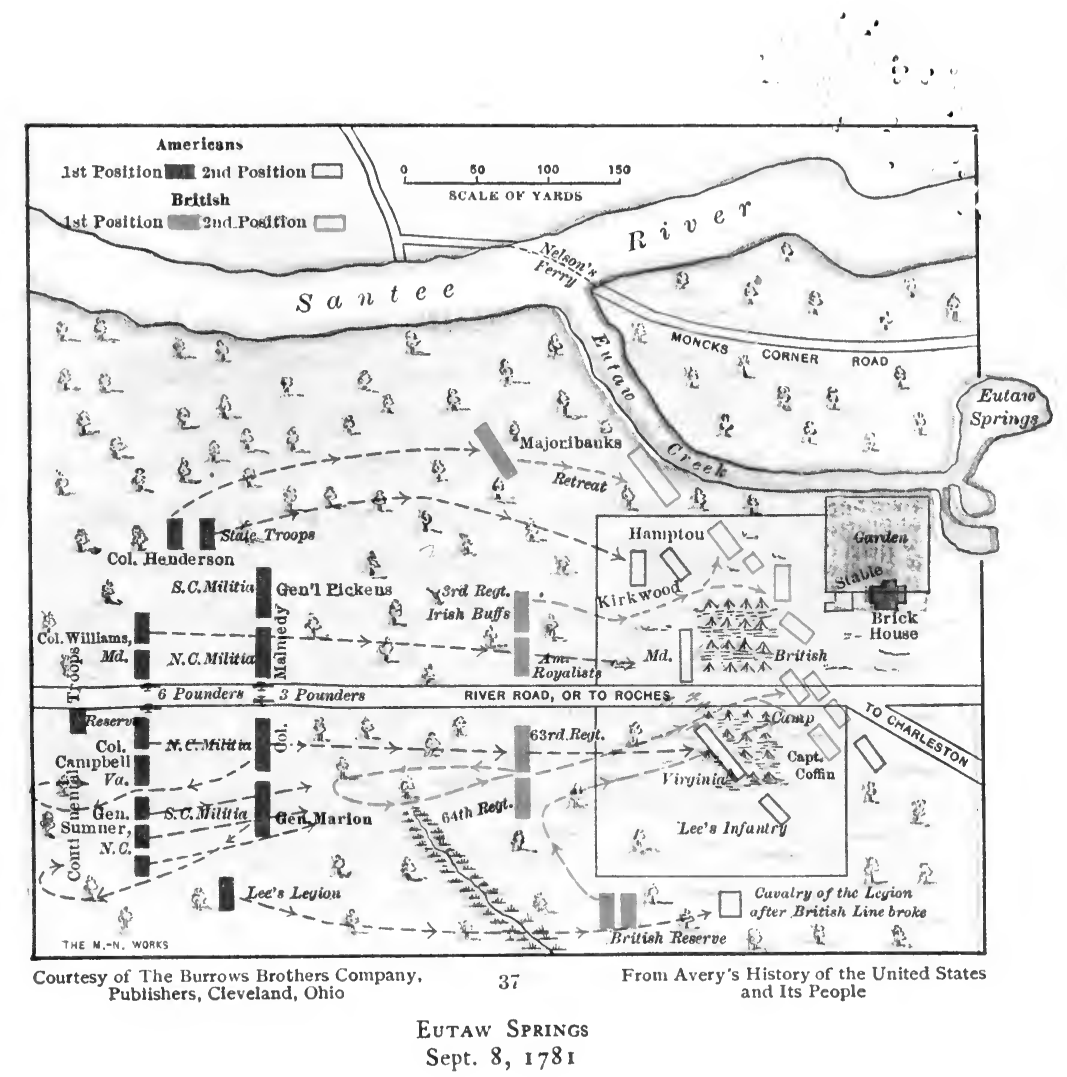




$$
\begin{aligned}
& \therefore, . \cdots \\
& \therefore \quad \therefore \\
& \therefore
\end{aligned}
$$


about 40 prisoners were taken and the rest rushed back 1781 to camp to give the alarm. Stewart promptly formed his men in a single line, 3 regiments on each side of the road and 2 pieces of artillery on the road.

Greene moved forward and, as he approached the Brit- Battle of ish position, deployed in two lines; the militia in front, Marion on the right and Pickens on the left and the North Eutaw Carolina militia in the centre; the Continentals in the second line, the two new North Carolina regiments on the right, the 1st and 2d Virginia in the centre, 1st and 2d Maryland on the left; two pieces of artillery in the centre of each line; Lee's Legion on the right flank and Henderson's (Sumter's) partisans on the left; William Washington's cavalry and the Delaware battalion in the rear.

The firing began at 150 yards and was soon very heavy. 10 м. м. The militia, under the guidance of Marion and Pickens, fought well and held their ground for some time; and when they were forced back Sumter's two North Carolina regiments came into line with them and the ground was regained. Soon afterward they were again forced back, and Greene then ordered Campbell and Williams with the Virginia and Maryland regiments to move forward without firing, relying on the bayonet; and at the same time sent Lee and William Washington to charge with their cavalry on both flanks. There was soon desperate fighting along the whole line. William Washington came to grief. In the wooded ground his dragoons were defeated with a loss of nearly half their strength, their leader himself being wounded and taken prisoner. The infantry and Lee's cavalry on the right were entirely successful. They drove the British regiments (after a desperate struggle, in which Campbell was killed and Henderson and Howard were wounded) to and through 
1781 their camp. Stewart succeeded in rallying his men at

Sept. 8

Battle of Eutaw Springs

$12 \mathrm{M.}$ the cross-roads in rear of his camp, and a portion of them took refuge in the brick house and the adjoining garden; and from the windows of the house and from the shelter of the stout garden fence they poured a very destructive fire upon the infantry of Lee's Legion and Kirkwood's Delaware battalion, who had followed to the door.

The Virginia and Maryland regiments stopped in the camp. It was filled with abundant supplies, including rum. It was so long since the Continentals had seen such delicacies that the temptation to partake of them was irresistible-especially as they thought the victory was already theirs.

The battle however, was not won. The little party in the brick house was keeping up a vigorous fight against the Delaware battalion and Hampton's regiment of Sumter's men; the four pieces of artillery were brought into action at close range, but they were unable to make any impression on the walls. Finally Major Marjoribanks came out of the garden and made a bold and successful attack (in which he was mortally wounded), turning Hampton's left flank and capturing three of the four pieces of artillery. Meanwhile the Continentals were enjoying the good things in camp, but Stewart was reforming his men at the cross-roads. He soon renewed his attack and the Continentals were in no condition to receive it. They began to fall back and Greene ordered a retreat, bringing off his own wounded as well as his prisoners.

It was a bloody battle ; ${ }^{1}$ the Americans lost 120 killed, 375 wounded and 8 missing; the British, 85 killed, 351

${ }^{1}$ Stedman, II, 377-381; Gordon, IV, 168-171; G. W. Greene, III, 391405; Johnson, II, 220-237; Dawson, 711-720. 
wounded and 430 missing - a total of nearly 40 per cent of their strength.

Both sides retreated, Greene on the night of the battle, about 7 miles, and Stewart the next day 14 miles, Results of the Battle leaving behind him a portion of his wounded and 1,000 muskets and destroying such stores as he could not carry away. As soon as Greene learned that Stewart sept. 10 had retreated he started in pursuit, but the latter was soon joined by a reinforcement from Charleston, and Greene returned to the Santee Hills.

Thus for the fourth time Greene failed to gain a victory in battle; the British rum unfortunately deprived him of it at the very moment of success. Again, as on the previous occasions, the advantages of victory were on his side, for the British retired to the vicinity of Charleston. Greene gave his men another short rest at the Santee Hills and then moved down to the Ashley in pursuit. After a sharp skirmish at the beginning of Action at Dorchester, winter he drove them within their lines at Charleston; and, although the garrison was many times superior to him in numbers, he maintained a strict blockade until the city was evacuated.

There was no serious fighting at the South after Eutaw Springs. The Carolinas and Georgia were recovered and the American governments were re-established. The two British garrisons remained quietly within the limits of Savannah and Charleston until they were evacuated and the troops carried by sea to New York.

Dec. 1

This eleven months' campaign-January to December, 1781, from the Catawba to the Dan and from the Dan back to Charleston and Augusta-received at the time the enthusiastic commendation of Washington and his comrades on the one side and of Tarleton and Stedman

Re-establishment of the American Government in the South 1782 July 11 Dec. 14 
1781

Comments on Greene's Southern Campaign

on the other. It has always been considered one of the most brilliant in American annals, and it has been quite as much praised by English as by American writers. Though the numbers on each side were small, yet from the military stand-point it is full of interest and instruction and well repays examination in all its details. The marches, the manœuvres, the sieges, the raids and the scouting by both Lee and Tarleton, the improvised pontoon trains, the proper use of the topography of the country for defence and offence-were all admirable. There was but little artillery on either side, but it was well handled. The four battles were fiercely contested and the percentage of loss on both sides was large. The British had the advantage of well-trained and well-armed troops, but this was more than counterbalanced by the superiority of the American generalship. In only one respect can Greene be criticised, and whether the criticism is just or unjust it is hard to say. He lost every battle. Morgan, under similar circumstances, gained a great victory. If Greene had possessed the same temperament as Morgan or Wayne he would probably, both at Guilford and at Eutaw, have made one more effort and risked everything on the result of it. If unsuccessful, he would have been destroyed; if successful, he would have hastened by a few months what he finally accomplished. The general opinion is, and it is probably well founded, that the circumstances did not justify the risk, and that his prudence-in saving his little army while there was yet time and after he had, in each case, inflicted such a loss on his adversary as to compel the adversary's retreat-was not the least of the many exhibitions of good judgment which characterized the whole campaign. 


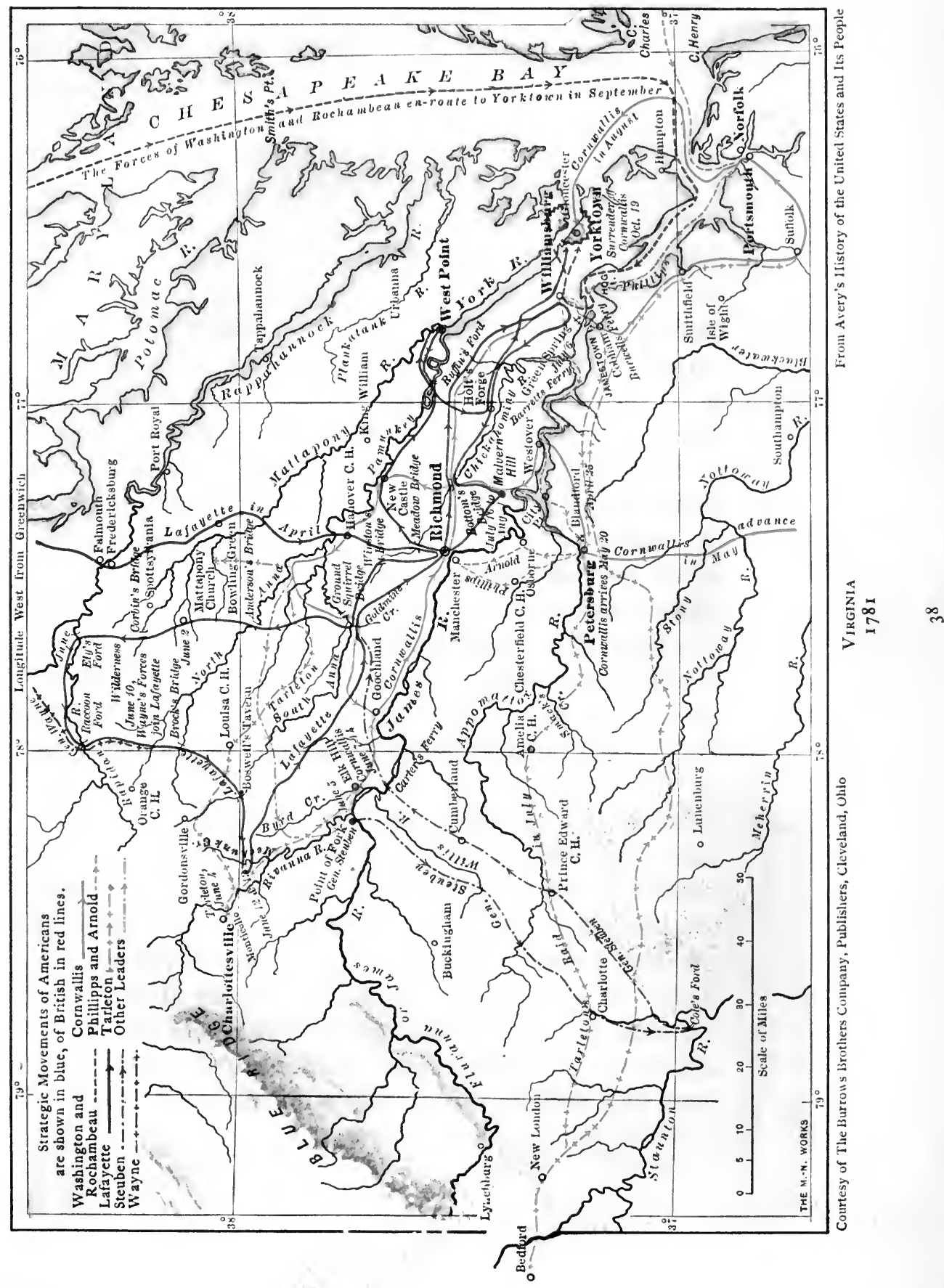




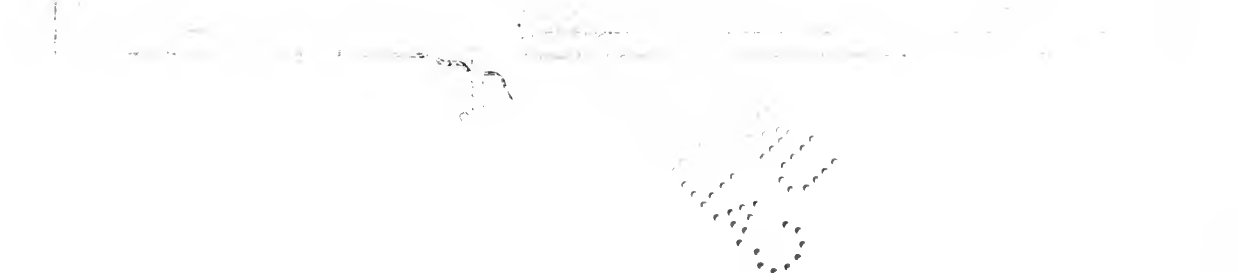




\section{CHAPTER VIII}

\section{YORKTOWN}

When Cornwallis, retreating from Guilford, reached 1781 Wilmington, he was in great perplexity. His letters were somewhat pathetic. To Phillips: "My situation here is april 24 very distressing; Greene has taken the advantage of my being obliged to come to this place, and has marched to South Carolina."1 To Clinton: "My present under- april 23 taking sits heavy on my mind." " To Germain: "If we are so unlucky as to suffer a severe blow in South Carolina ... this might enable General Greene to hem Perplexity of me in among the great rivers and by cutting off

our subsistence render our arms useless. And to remain here for transports to carry us off ... would be as ruinous and disgraceful to Britain as most events could be."”

His view was that if the war was to be offensive it april 22 should be in Virginia; if defensive, at New York. In either event he had no hope of saving the Carolinas. He was by no means sure that Clinton would approve his views. He very much desired Clinton's instructions, but it would take six weeks or more to obtain them, and he could not wait that long. He had already wasted two weeks in thinking about it, and when he received definite information that Phillips had been

${ }^{1}$ Clinton-Cornwallis, I, 428.

${ }^{2}$ Ibid., I, 424.

${ }^{3}$ Ibid., I, 421, 422 . 
1781

Decides to

March to

Virginia

April 24

May 20

Situation in Virginia

1780

Oct. 15

Nov. 25

Dec. 20

1781

Feb. 24

Feb. 15

March 10

IIarch 16

ordered to Virginia he decided to march thither and join him. ${ }^{1}$

Having made his decision, Cornwallis marched from Wilmington; and following what is now the line of the Wilmington and Weldon Railroad, through Goldsborough and Weldon, he reached Petersburg-223 miles-at the end of four weeks. ${ }^{2}$ Here he found that Clinton had bent every effort to send a sufficient force into Virginia, via the Chesapeake, to cut Greene's communications, and that Washington had stripped his little army of every man that could be spared, in order to keep these communications open.

Clinton first had sent Leslie with 2,500 men to Hampton Roads; and when Cornwallis had taken these to Charleston, Clinton had sent Arnold with 1,600 men to take their place. Then Washington sent Lafayette with 1,200 men to join Steuben, and at the same time ordered Wayne with 1,000 men to follow Lafayette, although Wayne was unable to march until three months later. Clinton met this by sending Phillips with 2,600 men to reinforce Arnold, and Washington persuaded Rochambeau to send 1,200 of the French troops at Newport to reinforce Lafayette. They never reached him because

1 This decision was approved by Germain, but Clinton maintained that it was the cause of the loss of his army and the disastrous termination of the war. His view was that Cornwallis should have gone back to South Carolina, collected his forces, which largely outnumbered Greene's, and beaten him in battle; to which the troops in Virginia would have contributed by cutting off Greene's communications with the North. Cornwallis maintained that Greene had made it impossible for him to march back to South Carolina, and that Virginia was the place for the final struggle. The controversy was maintained, so long as Clinton lived, in almost endless Narratives and Replies, which by the industry of Mr. B. F. Stevens were collected, arranged and printed so that every one can now read both sides. Clinton-Cornwallis, I and II.

2 Tarleton, 291. 

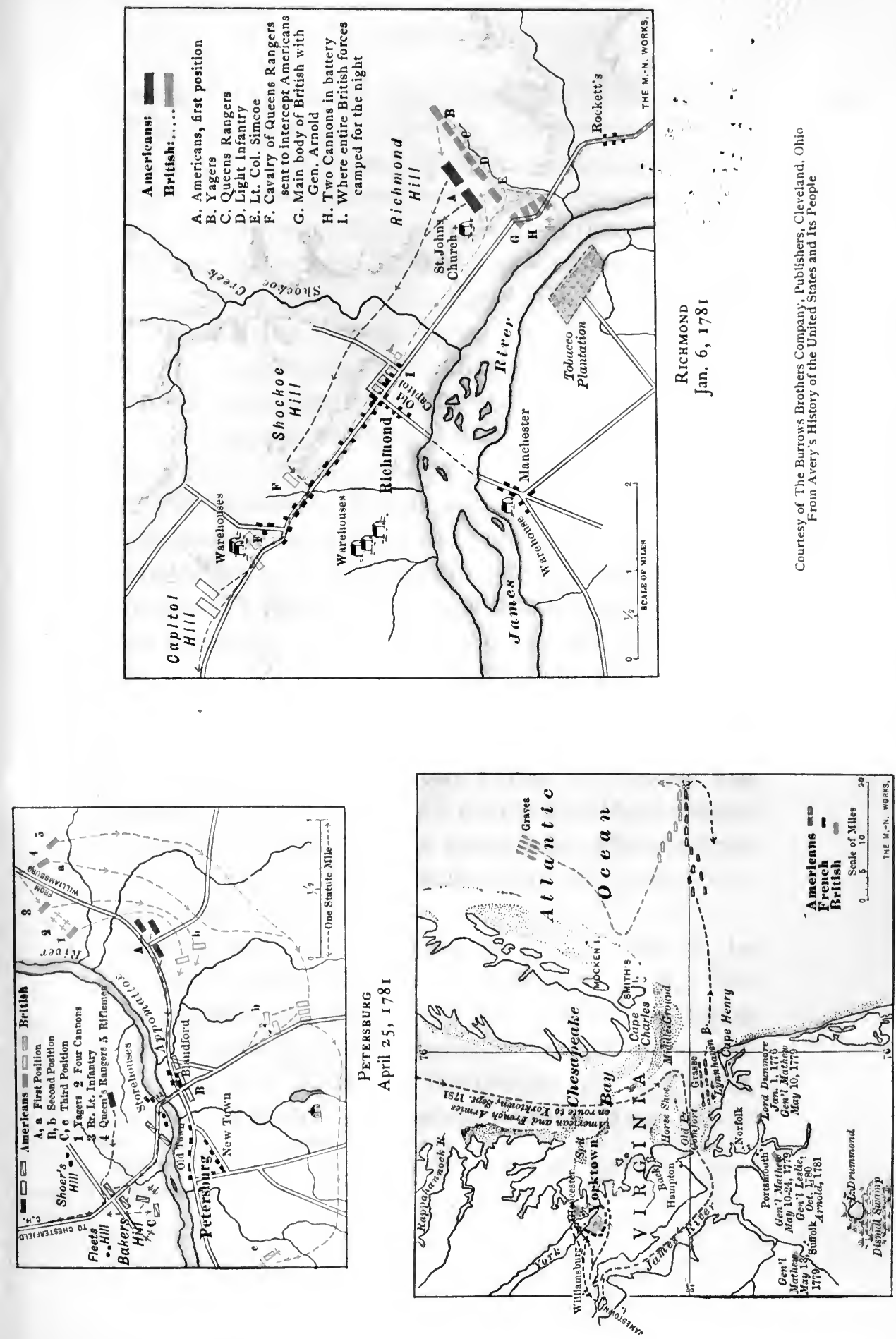

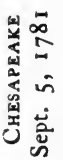


$4:$

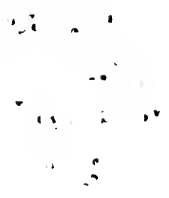

1 
the squadron convoying them was met and defeated by a British squadron, and thereupon they returned to Newport. Finally Clinton sent three more regiments $(1,500$ may 23 men) to reinforce Phillips, ${ }^{1}$ and these arrived at Petersburg a few days after Cornwallis reached that point. ${ }^{2}$

Clinton had thus sent 5,700 men to Virginia ${ }^{3}$; Washington could only send 1,200. Cornwallis brought 1,500 with him, carrying his total strength to 7,200. Lafayette had gathered a few hundred militia; Steuben was in the vicinity of Charlottesville, trying to raise eighteen months' men to fill up Greene's new Continental regiments; and Wayne, although supposed to be marching through Maryland, had not in fact left York, Pa., at the time that mas 24 Cornwallis marched to cross the James.

Cornwallis argued, then and afterward, in favor of "solid operations in Virginia." Here was his chance. Lafayette was at Richmond, only twenty miles off, with a force onesixth as large as his own. Destroy him, and break up Cornwallis's Steuben's recruiting depot at the mouth of the Rivanna, Foverements and his march to Virginia would have been justified not only to Clinton but to all the world. Cornwallis lost the chance; and his movements for the next three months can only be characterized as feeble-far different from the energy which he had displayed in the Jerseys four years before.

Lee and Jackson have shown what a general of the first rank would have done in Cornwallis's situation. Undoubtedly either of them would have crossed the James above Richmond, between Lafayette and Steuben, and marched rapidly across the headwaters of the Virginia

${ }^{1}$ Phillips died a few days before Cornwallis arrived and Arnold was sent back to New York soon after.

${ }^{2}$ Sparks, VIII, 10, 13, 19, 22, 510-516; Tarleton, 285-292.

${ }^{3}$ Clinton-Cornwallis, I, 476-499. 
1781 streams to get between Lafayette and Wayne. With sufficient celerity of action, all three detachments could have been either destroyed or dispersed.

Cornwallis's base was the sea, and he could not forget it. His communications with New York were via the lower James, and he was not willing to cut loose and take the risk of Lafayette's small force getting in his rear.

May 26

Lafayette's Energetic Action

Mag 27

June 4

June 1

June 7

June 9

June 10 He therefore crossed the James 30 miles below Richmond, at Westover; and his plans extended no further than "to dislodge Lafayette from Richmond and with my [his] light troops to destroy any magazines or stores in the neighborhood" and then "to move to the neck (peninsula) at Williamsburg." 1

It was Lafayette who acted with the proper celerity. He promptly retreated to Ely's Ford on the Rapidan, covering the 70 miles in 7 days. Cornwallis pursued no farther than the North Anna (30 miles). He then sent his cavalry (which outnumbered that of Lafayette 10 to 1) on two raids, one under Tarleton to Charlottesville to disperse the legislature, and the other under Simcoe to break up Steuben's depot at Point of Fork, where the Rivanna empties into the James, 50 miles above Richmond. With the main body he followed leisurely to the latter point (40 miles in 6 days), and was joined there by Tarleton and Simcoe, who had accomplished the object of their raids, destroying a great deal of tobacco and some arms and supplies. Steuben was forced to march rapidly southward with his 450 Continental recruits; but he was not pursued. He halted at Cole's Ferry, on the Staunton River, and waited for further advices or instructions from either Greene or Lafayette. ${ }^{2}$

${ }^{1}$ Clinton-Cornwallis, I, 488.

${ }^{2}$ Tarleton, 295-299; Kapp, Steuben, 448-450. 
Meanwhile, Wayne was marching south with good 1731 speed. He made the 160 miles from York, Pa., to the Arrival of Rapidan in 14 days, and he joined Lafayette without Wayne, 26 any serious effort on Cornwallis's part to prevent it, June 10 although the latter knew that Wayne was on his way to reinforce Lafayette. As soon as the junction was made, Cornwallis retreated through Richmond to Williamsburg, June 14-26 Lafayette following him, and Steuben joining Lafayette on the march. On the outskirts of this little village the first shot was fired after a month of marching. It was June 9 an inconclusive skirmish between advance guard and rear guard, with a loss of about 30 men on each side. ${ }^{1}$

At Williamsburg Cornwallis received a letter from Clinton asking him to send about 3,000 men to New York. Cornwallis thereupon changed his plan of remaining at Williamsburg and prepared to cross the James and march to Portsmouth, where the men would embark. As he approached the river at Jamestown Lafayette pressed close to him and a smart engagement ${ }^{2}$ resulted in which Battle of Jamestown, the Americans lost 26 killed, 99 wounded and 12 missing, chiefly in Wayne's Pennsylvania regiments; and Cornwallis lost 5 killed and 70 wounded.

Lafayette was defeated, but Cornwallis made no attempt to follow him and he retired slowly to Malvern Hill, below Richmond. The next day Cornwallis crossed July 7 the James, and sending on to Portsmouth the troops designated for embarkation, with the rest he marched as far as Suffolk. Tarleton was sent on a long raid ${ }^{3}$ across July 9-24 the State to the mountains and back-400 miles in 15 days-to destroy the stores which Steuben had been accumulating for the Southern army. These had beer

${ }^{1}$ Dawson, 698-700.

2 Tarleton, 354; Dawson, 701-704.

3 Tarleton, 358. 
1781 safely removed and all that Tarleton accomplished was to burn up a good many hogsheads of tobacco.

A situation then existed on the British side which had a most important bearing on the issue of the campaign. It was somewhat similar to that of four years before which resulted so disastrously at Saratoga. ${ }^{1}$

Lack of Military Coordination on the Part of the British
In London, Lord George Germain-probably the most incompetent official that ever held an important post at a critical moment-was Colonial Secretary, charged with the conduct of the war under the personal direction of the King, with whom he was a great favorite. His letters were sometimes six weeks and sometimes three months in crossing the ocean, and when they reached their destination the state of facts on which they were based had usually changed. Yet he undertook to direct the operations at this distance and corresponded directly with Clinton and with Cornwallis-frequently giving contradictory instructions.

At New York, Clinton, who was commander-in-chief of the land forces and peace commissioner as well, was responsible for the operations; but he had no control over the navy, whose co-operation was absolutely essential as all plans were based on the control of the sea. Sometimes the naval commander was in accord with Clinton and sometimes he was not; and in the latter cases he acted on his own judgment, regardless of Clinton's plans.

At the south, from Virginia to Georgia, Cornwallis was in chief command. His letters reached New York in from eight days to two months. Clinton's letters to him were very numerous, and they were such as not to leave Cornwallis a free hand; neither did they give him

${ }^{2}$ P. 79, ante. 
positive orders. Clinton and Cornwallis had different views as to the proper plan of campaign, and Germain favored those of Cornwallis. Clinton sent instructions to Cornwallis, always with a saving clause that if the latter had other plans in view the instructions were not to be followed. Cornwallis tried to follow these directions, but every move he made was disapproved. Clinton censured him for marching north from Wilmington, for not remaining at Williamsburg, for going to Portsmouth and finally for selecting Yorktown as the naval station. Clinton did not give him any positive instructions nor do his letters contain any clear, definite, matured plan. ${ }^{1}$

With such lack of co-operation and co-ordination among those in the highest authority, success would under any circumstances have been difficult.

On the American side military conditions were far more favorable. When Greene was sent to the South Congress gave him full authority and placed at his disFavorable Conditions on the American Side posal all its resources-they were meagre enough, but it was absolutely everything they had. Washington gave Greene the benefit of his advice before he left and after that never sent him an order, although he continued to accord him the most hearty and unstinted support. In short, the government and the commander-in-chief gave the local commander every assistance they could command and they both left to him the conduct of the campaign.

On the American side there was precisely that cooperation and co-ordination which was so completely lacking on the British side, and it was one of the prime factors of success. There were lessons in these opera-

${ }^{1}$ Clinton-Cornwallis, I, 493; II, 15, 53, 73, 98, 109, 143. 
1781

Clinton's Instructions to Cornwallis

June 11-15-19

tions of 1781 which if they had been learned and applied in the Civil War would have saved many lives.

The instructions which Cornwallis received from Clinton-always with a reservation as above stated-repeated in three successive letters, were to send about 3,000 men to New York. The reason given was that Washington and the French allies were approaching New York, and Clinton feared he had not enough men for its defence-a reason which would override the reservations. Cornwallis received the first two of these letters at Williamsburg, and crossed the James to march to Portsmouth and obey them. While on the march he received June 28 another letter, of later date, ordering the detachment to Philadelphia instead of New York. Four days later July 1 came another letter, of subsequent date, ignoring the orders for Philadelphia, but urging immediate despatch of troops to New York. Before the troops could be put July 11 on the transports came a sixth and a seventh letter, July 15 dated later than the others, directing him to keep all his troops in Virginia and to occupy Old Point Comfort as a support for the fleet which was to be sent to Hampton Roads. Cornwallis at once went in person to examine Old Point Comfort, taking with him his army engineers and the naval commanders then present. They were all of opinion, and so reported in writing, that Old Point Comfort was not suitable for defence. Inasmuch as Clinton and Graves (the naval commander-in-chief) had both urged the supreme importance of establishing a naval station in the Chesapeake, supported by defensive works on shore, Cornwallis selected the harbor between Yorktown and Gloucester as the one best adapted for that purpose. He informed Clinton and Graves of his decision, as being in accordance with the spirit of his 
orders, and also in accordance with the opinion which 1781 Phillips had given Clinton ${ }^{1}$ - that Yorktown was the proper station-which opinion Clinton had previously sent to Cornwallis for his guidance. The transports being now at Portsmouth, the troops were sent to Gloucester Cornwallis Arrives at and Yorktown as quickly as possible, the lines of field fortifications were laid out and the work of constructing them was begun.

Some excuse for the vacillating and contradictory aug. 2 orders that Clinton gave may be found in the masterly plans that Washington had recently been formulating and was now putting into effect. For three years, with infinite patience and tact, Washington had been trying to obtain some positive, tangible, military benefit from the French alliance. There was no doubt of its moral, political and financial advantage; but as yet the French Washington's Plans troops had taken little or no part in the military operations. In 1778 the French fleet had been blown away from Newport carrying the soldiers with it. In 1779 it had to come to Savannah for a short period, only to engage in a disastrous repulse. In 1780 it had got into Newport, but had been bottled up there ever since. Now, at last, the diplomatic but incessant arguments of Washington with Rochambeau at Newport, and the less diplomatic but effective efforts of Laurens supported by Franklin in Paris, began to have their effect. A new fleet was to be sent under de Grasse to the West Indies and thence to the American coast-to co-operate with Rochambeau under Washington's direction.

As soon as Washington heard of this at his head- May 22 quarters at New Windsor (Newburg) he set out for Wethersfield (near Hartford) and there met Rocham-

${ }^{1}$ Clinton-Cornwallis, II, 19, 24, 26, 29, 41, 49, 61, 73. 
1781 beau. ${ }^{1}$ They perfected the details of an attack on New York-the obvious plan, for the accomplishment of which Washington had so often asked the co-operation of the French. Washington again sent to the New England governors ${ }^{2}$ the most urgent request that they fill up their quota in the Continental regiments, for one season if the men could not be obtained for longer. A small portion of de Grasse's fleet soon arrived in Boston, bringing 700 recruits for the regiments at Newport and announcing what de Grasse's movements would be. He intended to arrive on the American coast in July or August. Letters were sent te him by Luzerne and Rochambeau, at Washington's suggestion, urgently requesting him to bring troops as well as ships from the West Indies, and to come to New York, stopping on his way at the Chesapeake, where perhaps he might find an opportunity for an important stroke. ${ }^{3}$

The Allies

Move Toward New York

June 10

July 6

July 2-3

July 20-23

The operations against New York then proceeded. The French army finally left Newport for Providence and then marched westward. Washington marched southward from the Highlands, and the two armies came together, taking a position extending from Dobb's Ferry to White Plains. An attempt was made by the advance guard under Lincoln to surprise and capture the posts on the north end of Manhattan Island, and by Lauzun's Legion to capture an outpost of Provincials in Morrisania; but both failed."

Washington then carefully reconnoitred from Fort Lee in New Jersey and from Chatterton's Hill across the Harlem, the fortifications of the British on Manhattan Island where he had himself first laid out the fortified

${ }^{1}$ Sparks, VIII, 54.

${ }^{3}$ Ibid., VIII, 64-78.
${ }^{2}$ Ibid., VIII, 51-53.

IIbid., VIII, 86-98. 
lines five years before. They were too strong to be at1781 tacked. The French had 4 regiments, Bourbonnais, Soissonnais, Saintonge and Royal-Deux-Ponts. They were 10 company regiments and their full complement was about 65 officers and 1,250 men each. There had been some sickness, and detachments had been left at Providence and elsewhere to guard their stores. Their effective strength was now about 930 each. In addition there was Lauzun's Legion, the artillery and the engineers. The entire French force was 4,756. ${ }^{1}$ Washington had little if any more, for his appeal to the New England governors had brought only a feeble response. Clinton had in New York about 14,000 effectives, ${ }^{2}$ in fortified lines, to reach which it was necessary to pass one or the other of the rivers, which were controlled by the smaller British vessels, while a large squadron was in the lower bay. Until de Grasse should arrive an attack was out of the question.

Washington's fertile mind was intently thinking of Washington's alternative plans; to be decided as soon as definite in- Plans telligence of de Grasse's movements should be received. He had written to Lafayette directing him to establish July 13 a line of "expresses" to keep him quickly informed of any movements of the enemy and similarly to inform Greene; he now wrote to both Greene and Lafayette, July 30 directing both of them to send him the most complete information they could obtain as to the strength and position of the British troops in Virginia and at Charleston, and intimating as clearly as he dared, in view of the possibility of his letters being intercepted as several had been recently, that a campaign to Virginia or a siege of

${ }^{1}$ Return of June 1; Keim, 389.

${ }^{2}$ Sparks, V, 544, 545. 
1781 Charleston might be the outcome of de Grasse's arrival. His later letters showed that he was considering three projects: if Clinton reinforced Cornwallis, to attack New York; if Cornwallis reinforced Clinton (as he thought the most probable), to march to Virginia; and if on arriving in the Chesapeake the conditions were favorable, to move by sea to Charleston and besiege it in conjunction with Greene. ${ }^{1}$

News from de Grasse

Aug. 14

July 8

The Allies March to Virginia

Aug. 15

Aug. 19

Aug. 17

Aug. 21

While he was thinking of these different plans, definite news came from de Grasse. The letter was addressed to Rochambeau and was dated at Cape St. Francis, San Domingo. It was clear and concise, very different from the letters that d'Estaing wrote. It stated that he would sail north on August 13; would bring with him 29 vessels of war and a portion of the garrison of San Domingo, to wit: 3 regiments, Gatinais, Agenois and Touraine, each 1,000 strong, together with 100 dragoons, 100 artillerymen, 10 field pieces and several siege cannon and mortars; he would proceed directly to the Chesapeake and would sail back to the West Indies on October 15, taking the troops with him. ${ }^{2}$

Washington made an instant decision; he would march to the Chesapeake to meet him. Orders were immediately despatched to Lafayette to prevent Cornwallis escaping to South Carolina; to Heath to take command of the little force, twelve small battalions, which was left in the north. A letter was sent by Duportail, the chief engineer, to de Grasse, explaining his plans, and asking him to send light vessels to Head of Elk in order to transport the troops down the Chesapeake. ${ }^{3}$ And then the allied armies were put in motion, crossing the Hudson at King's Ferry to Stony Point, then marching

$$
{ }^{1} \text { Sparks, VIII, 116-122. I I Ibid., VIII, 522. I I Ibid., 127-139 }
$$


behind the Palisades to Newark and New Brunswick, 1781 making a feint against Staten Island, and then on through sept. 1 Philadelphia to Head of Elk. So skilfully had Washington conducted this movement and concealed it from the enemy that the troops had been 14 days on the march, and most of them had passed Philadelphia when Clinton wrote to Cornwallis:" "By intelligence which I have this day received, it would seem that Mr. Washington is sept. 2 moving an army to the southward, with an appearance of haste, and gives out that he expects the co-operation of a considerable French armament."

In making this move Washington put everything to the hazard. A vigorous antagonist would have marched Boldness of Washington's up the Hudson, scattered Heath's little force, seized the aug. 11 Highlands and held them. Clinton had just been reinforced by 2,500 Hessians, and his own return showed an effective strength at New York of 16,701 men. ${ }^{2}$ Heath had, at the most, 2,500. Can there be any doubt of what a man like Grant or Lee would have done in Clinton's place? Further, if Washington failed in Virginia, New England was hopelessly separated from the South, and notwithstanding the Carolinas and Georgia had been regained, the Revolution would have collapsed.

Daring as was the plan, it was eminently wise; for without a great victory the Revolution would die of exhaustion. It was a time-as it had been at Trentonwhen nothing but audacity would avail; and it indicates the extraordinary balance and poise of Washington's mind that he could wait three long years for the psychological moment to arrive, and when it did arrive that he instantly took advantage of it.

${ }^{1}$ Clinton-Cornwallis, II, 149, 150.

${ }^{2}$ Sparks, V, 545. 
In boldness of conception and celerity of execution this march to Virginia was comparable with Napoleon's famous campaign of 1805 , when he suddenly abandoned the camp which he had formed at Boulogne for the invasion of England and marched to the Danube. The distance was about the same, 400 miles. Washington covered it in 28 days, Napoleon in 35 days. Napoleon left the Channel on August 27, and the capitulation of Ulm took place on October 15-49 days later. Washington crossed the Hudson August 21, and the surrender of Yorktown was on October 19-59 days. Washington's resources in men, money, equipment, supplies and transportation were but a small fraction of those at Napoleon's disposal; but the effect on the world's history of Ulm and Austerlitz was a still smaller fraction of the results which flowed from Yorktown.

Movements of the French and English Fleets

Aug. 31

Aug. 30

Sept. 5
It was an integral part of Washington's plan that the French should for the time being at least control the sea, and fortunately the naval commander was of a different type from d'Estaing. De Grasse came up through the Bahama Channel instead of the direct route, and Hood, who left the Windward Islands in pursuit, thus passed him without knowing it. After looking in at the Chesapeake, Hood went on to New York, and the united fleet, under Graves, immediately sailed for the Chesapeake, hoping to intercept de Barras's smaller fleet (which was on its way from Newport) before it could join de Grasse. In the interval de Grasse had passed inside of Cape Henry. He at once sent the land troops-the brigade of St. Simon - up to the James River and landed them near Williamsburg, where they were joined two days later by Lafayette who had marched down from Malvern Hill to meet them.

${ }^{1}$ Mahan, 389. 
On the day the French troops landed the British fleet came in sight of Cape Henry. De Grasse went out to fight them, but, unlike d'Estaing at Newport, he did not 1781

Naval Battle off the carry his soldiers with him. These were left with Lafayette. The naval engagement was inconclusive, both sides losing heavily in men and guns, and then manœuvring for four days without renewing the action. The net result was very advantageous to de Grasse, for the British admiral found it necessary to take his fleet back to New York for repairs. De Grasse was left in control of the Chesapeake, and during the manœuvring de Barras slipped in between the capes, bringing with him some recruits for the French regiments and a large train of siege artillery. ${ }^{1}$

Clinton at New York learned from Cornwallis prior to clinton Goes Graves's return that de Grasse was in the Chesapeake, cornelief of and saw at once that the only chance to save Cornwallis was to join him with troops from New York. He there- Sept. 6 fore embarked 4,000 men on transports and wrote to Cornwallis that he would sail with them as soon as the admiral could furnish a convoy. It was six weeks before the British ships were sufficiently repaired to furnish a convoy. Clinton then sailed with 7,000 men, but when he oct. 19 reached the capes he learned that Cornwallis had already oct. 24 surrendered, and he retraced his steps to New York. ${ }^{2}$

Meanwhile, Washington had joined Lafayette at Williamsburg and his troops continued to arrive during the next ten days; some marching by land, but the greater Sept. 14 Arrival of the number coming down the Chesapeake from Annapolis, Washington Baltimore and Head of Elk in small vessels furnished by the French. The entire force ${ }^{3}$ - the French from New-

${ }^{1}$ Mahan, $389 . \quad \quad{ }^{2}$ Clinton-Cornwallis, II, 152, 172, 186, 188.

${ }^{3}$ Johnston, Yorktown, 112-119. 
1781 port, the Americans from the Hudson, Lafayette's troops from Virginia and the French from Haiti-numbered about 16,600 men. The Americans were organized into 3 divisions under Lincoln, Lafayette and Steuben; there were the remnants of 17 infantry regiments from each of the States from Massachusetts to Virginia, 4 artillery regiments and 1 of cavalry-in all 5,645 Continentals; and there were 3 brigades of new militia-3,200 menfrom Virginia under command of the governor, Nelson. The French were organized in 2 brigades, and there were 7 regiments of infantry, 1 of artillery and 1 of cavalryabout 7,800 rank and file, effective, in all.

Cornwallis's return gave 5,316 effective. He had 1 Provincial, 4 Hessian and 11 British regiments, besides artillery and the cavalry of Simcoe's Rangers and Tarleton's Legion.

Siege of Yorktown

Sept. 28

Sept. 30

Oct. 6

Oct. 11

Oct. 14

Oct. 15

As soon as his army was assembled and organized Washington moved forward from Williamsburg and surrounded Yorktown, the Americans on the right and the French on the left. The siege was begun and prosecuted in thoroughly military fashion. Cornwallis did not feel strong enough to occupy his outlying works south-east of the village, and he therefore abandoned them. They were immediately occupied by the allies, and from them the first parallel was opened at 600 yards; the siege-guns had been landed from de Barras's fleet and brought to the trenches, and were vigorously used. The approaches were carried forward and the second parallel was opened, at 300 yards. Then a most gallant night assault was made, Alexander Hamilton in the lead, and two redoubts were carried near the river on the British left. The second parallel was promptly extended to include these. On the following night just before daybreak Cornwallis made a 


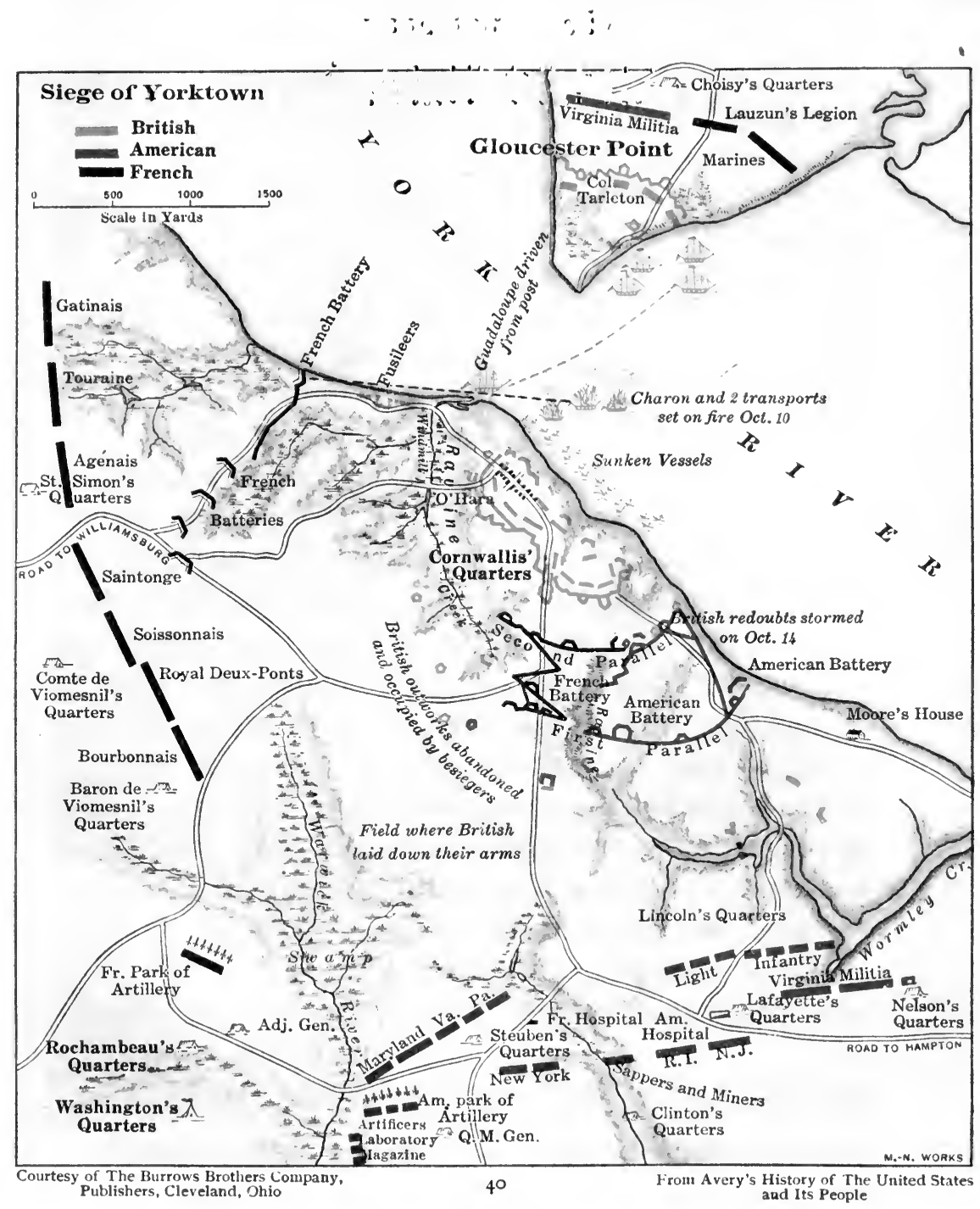

YoRkTOWN

Sept. 30-Oct. 19, 1781 


$$
\begin{aligned}
& \text { - } \because \because \because \quad,
\end{aligned}
$$

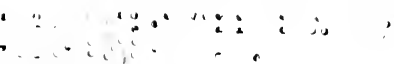


vigorous sortie with the Guards and light infantry, carried 1781 two batteries, hastily and imperfectly spiked the guns and inflicted a loss of about 100 men on the French. They could not hold the position and were driven back to their own lines. ${ }^{1}$

Cornwallis then attempted to ferry his men across to oct. 16 Gloucester in a desperate plan of trying to save his army by marching toward Philadelphia; but this plan was completely frustrated at the start by a violent storm which arose during the night and scattered and swamped his boats. With great difficulty his men were reassembled on the Yorktown side. Then Cornwallis opened oct. 17 negotiations for surrender and two days later the capit- oct. 19 ulation was signed. Washington took care that there capitulation should be no such mistakes as had been made at Saraat Yorktown toga. The garrison, including the naval force, was to be surrendered as prisoners of war; all public property was to belong to the United States; no engagement was made as to future exchange of prisoners, "the soldiers to be kept in Virginia, Maryland or Pennsylvania .... and supplied with . . . rations"; the officers to be allowed to go to England or New York or elsewhere on parole; no stipulation as to the civil rights of the inhabitants; a ship to be furnished to carry Cornwallis's sealed despatches to New York. ${ }^{2}$

It was a long time before the prisoners were exchanged, and there never was a word of controversy concerning the capitulation.

The number surrendered ${ }^{3}$ was 7,157 soldiers, 840 sea-

${ }^{1}$ Johnston, Yorktown, 120-149; Dawson, 733-744; Tarleton, 368-393, 414-433.

2 The Articles of Capitulation are given in full in Tarleton, 438-442; Johnston, Yorktown, 186-189; Clinton-Cornwallis, 199-203; Sparks, VIII, 533-536.

${ }^{3}$ Johnston, Yorktown, 164, 169, 194; Tarleton, 390, 448-451. 
Comment on Cornwallis's Surrender

men and 80 camp followers-8,077 in all. In addition there were 144 cannon, 6,658 muskets, large quantities of ammunition, supplies and clothing belonging to the army and 4 frigates, 30 transports, 15 galleys and several smaller vessels belonging to the navy. The losses during the siege had been: British, 156 killed and 326 wounded; allies, 75 killed and 199 wounded. Two-thirds of the losses of the allies were sustained by the French.

Could Cornwallis have saved his army? The attempt he made the day before he opened negotiations for surrender would almost certainly have resulted in overwhelming disaster. The celerity with which Washington marched to Virginia indicates the vigor with which he would have pursued any such attempt. Cornwallis, followed and harassed by an enemy outnumbering him three to one, the greater part of its troops well equipped and all of them supported by the French fleet moving up the Chesapeake, would have had small chance of ever reaching Philadelphia. There was an opportunity four weeks earlier when success was possible. When de Grasse returned within the capes after his engagement with the British fleet, the allied army was only beginning to arrive. The force then opposed to Cornwallis was about 2,000 Continentals under Lafayette and the 3 French regiments from the West Indies. The roll of these latter shows 187 officers and 3,337 men ;' but many of them were sick with scurvy, and it is not probable that more than 2,200 were effective. Lafayette's total force was thus not more than 4,200 effective. Cornwallis had 5,100 effective. If he could have defeated Lafayette, or driven him back to Richmond, he might have crossed the James and marched to Charleston. Tarleton argues ${ }^{2}$ that

${ }^{1}$ Keim, 507 .

${ }^{2}$ Tarleton, 369. 
this should have been attempted and would have suc1781 ceeded. The distance was 420 miles, through a hostile country all the way, with many rivers to cross, with Washington and the allies following from the North, and Greene facing him from the South as soon as he reached South Carolina. It does not seem probable that it could have succeeded. Cornwallis did not attempt it, because he had already received Clinton's letter of Septemper 6 telling him that he was coming to his relief; and he could not doubt that the British would beat the French on the sea.

Did Cornwallis surrender too soon? When he opened oct. 10 negotiations he had 2,089 on the sick report and about 4,700 effective. He had upward of $350,000^{1}$ pounds of provisions; with proper care this would have lasted from 20 to 25 days. Clinton, with 7,000 men, arrived off the capes within 7 days. The fleet which convoyed him contained 27 ships of the line; de Grasse had 36 . If Cornwallis had held out 10 days longer, in the naval engagement that would have taken place there was a chance that the British would have won, and the addition of 7,000 regulars to Cornwallis's force would have changed the whole situation. Cornwallis had received a week before a letter from Clinton saying that he would sail on the 12th. There is ground for argument that neither the number of his sick nor the state of his food supplies justified him in surrendering at the time he did, and that he should have awaited Clinton's arrival and the result of the naval battle which that would bring on. Cornwallis gave his reasons as follows:" that his works "were going to ruin," that it would be "desperate to attempt to maintain them," that he "could not fire a single gun," that

'Tarleton, 457.

${ }^{2}$ Clinton-Cornwallis, II, 212, 213. 
1781 his "numbers had been diminished by the enemy's fire, but particularly by sickness" and that "it would have been wanton and inhuman to the last degree to sacrifice the lives" of his soldiers "by exposing them to an assault, which from the numbers and precautions of the enemy could not fail to succeed."

On his return to England Cornwallis was never brought to trial nor even censured-except in Clinton's pamphlets. He lived twenty-five years longer, the greater part of which was spent as governor-general and commanderin-chief in India; where in the siege of Seringapatam and in his campaigns against Tippoo Sahib he conquered for his country a large part of what is now the Indian Empire. His contemporaries did not blame him for the loss of Yorktown, and the general opinion has since been that the surrender was due to the masterly combination of Washington from which no escape was possible.

End of the War

Treaty of Peace
The war practically ended with Yorktown. Washington tried to persuade de Grasse to join him in an expedition against Charleston or in one against New York. The latter, however, insisted on returning to the West Indies. The troops were then scattered: Wayne and the Pennsylvania Continentals were sent to reinforce Greene at the South; Rochambeau remained at Williamsburg; St. Simon's brigade was sent back to Haiti; Washington and the New York and New England Continentals returned to the Hudson; Lafayette went back to France. In the following spring Clinton was superseded by Carleton.

There were no more military movements. A year was spent in negotiating the treaty of peace, and during this year Savannah and Charleston were evacuated, as previously stated. When the treaty had been signed 
New York was evacuated. The war was over and the 1783 independence of the United States was established and Nov. 25 acknowledged.

The war had called forth the entire military strength of Great Britain - most of her navy, nearly all of her army and all the mercenaries that her money could hire. She sent to America 57 British and 30 Hessian regiments, and raised in or near New York 12 Provincial regiments which were thoroughly organized and equipped and served from three to six years. The number of seamen exceeded 40,000, in more than 100 ships, and with these Great Britain kept control of the sea for the entire eight years, with the exception of forty-one days in 1779 and sixty-four days in 1781 .

Considered in the light of its influence upon the progress of mankind, the Revolution was one of the most important wars in the whole history of the world. The result was due-more than to all other causes combined - to the ability of Washington as a soldier. His political services were of such surpassing importance and value that it has long been the fashion to speak disparagingly or at least apologetically of his military achievements. If his campaigns are carefully studied, no other conclusion can be reached than that they were most skilfully conducted; and if Washington had died at any time between 1783 and 1789 he would have been known in history as one of the great soldiers of all time.

In his principal battles, Long Island, Brandywine and Germantown, he was either defeated or the result was inconclusive. This was not because they were badly planned, but because the soldiers by whom they were fought, while brave and patriotic, were deficient in train- 
1783 ing, experience and discipline-were not as efficient instruments for accomplishing a specific purpose, plans for which had been properly made, as were their opponents. At Monmouth the combined treason and incapacity of Charles Lee robbed Washington of a well-deserved victory. At Fort Washington, his own indecision caused a grave disaster. This is about the only criticism that can be made of his military acts during eight long years of warfare.

Against this are the achievements on which his military reputation securely rests: the marvellous retreat from Long Island, the audacious attack at Trenton and Princeton, the well-planned movement from Valley Forge, when Howe evacuated Philadelphia, and the brilliant march to Yorktown. These four events occurred at intervals during five years, and between them were periods of enforced inaction compelled by the poverty of military resources. Those were the Fabian periods during which any other policy would have resulted in ruin. The four offensive events were Napoleonic. Each of them was characterized by an extraordinary exhibition of daring, celerity and skill, the three qualities to which both Cæsar and Napoleon owed their classic triumphs. It was in the domain of strategy rather than of tactics that Washington's genius was exhibited, and his successes were due to well-matured plans and rapid marches; the accidents of battle were nearly always unfavorable to him. He possessed the gaudium certaminis in a marked degree, and in the mêlées at Kip's Bay, Princeton and Germantown his reckless exposure was phenomenal. The placid benignity which Stuart placed in the portraits which he painted a few years before Washington's death, and the austere character which Sparks has embodied in his 
twelve volumes, must not make us forget that during the Revolution, at the age of forty-four to fifty-one, Washington had very warm blood in his veins. He was a man of passionate vigor, intense energy and affectionate sympathy. He was a pre-eminent soldier. 
PART II

\section{THE MILITARY POLICY OF THE UNITED STATES}

"Regular troops are alone equal to the exigencies of modern war, as well for defence as offence, and whenever a substitute is attempted it must prove illusory and ruinous."

-George Washington. 


\section{CHAPTER I}

\section{THE POPULAR FAITH IN AN UNTRAINED MILITIA}

ThE usual statement of our military policy is that we maintain a small regular army in time of peace, raise large volunteer forces in time of war and maintain at all times a "well-regulated militia" in the various States. This policy rests upon certain fundamental principles, viz., distrust of a standing army, reliance upon untrained troops and dependence upon voluntary service. It is a singular fact that while we have been successful, not only in the general result, but in the specific military events, in all our wars except the second war with Great Britain, yet the principles upon which our armies have been raised and organized have been denounced by professional soldiers in every generation, beginning with Washington, as wasteful, extravagant, inefficient and wrong.

The policy which we have adopted was not, as Glad- Origin of stone said of the Constitution, "struck off at one time by Policy the brain and purpose of man," but, on the contrary, is due in part to our geographical situation, but chiefly to racial prejudices which have their roots far back in English history; as far back, indeed, as the very beginning of English-as distinguished from British-history, in the fifth and sixth centuries. The Teutonic tribes which then conquered Britain and founded England brought 
with them two ideas of profound significance, ${ }^{1}$ viz., the ideas of representative government and of voluntary military service; and these ideas or principles have never been abandoned, but have been maintained, developed and enlarged during nearly fifteen hundred years. They are the foundation of English civilization, English government and English habit of thought. Our ancestors brought them to America in the seventeenth century, at the very time when the Stuart kings were endeavoring to rule without Parliament, to levy taxes without legislative sanction, to create a standing army for the destruction of the liberties and the religion of the English people. These twin principles-representative government and voluntary military service-were the foundation of the state, no less in Virginia than in New England $^{2}$; for, while the Puritan looked upon the army as the instrument of oppression, to the Cavalier the words "standing army" meant Cromwell's disciplined troops, who had arrested members of Parliament, stabled their horses in cathedrals, insulted and robbed the nobility

Ancient

Hatred of a Standing Army and gentry and murdered the king. To both Cavaliers and Puritans, therefore, as they founded their settlements in America, the name of standing army was hateful, with a bitterness and intensity of hatred which we can at this distance hardly appreciate. A hundred years or more later this hatred was, if possible, still further intensified by the acts of an English king and Parliament,

1 "The base of the new English society was the freeman. ... War was no sooner over than the warrior settled down into the farmer. . . . Each little village commonwealth lived the same life in Britain as its farmers had lived at home. Each . . . made laws in the assembly of its wise men, and chose its own leaders among the 'earls' for peace or war." (J. R. Green, Short History of the English People, 12. See also John Fiske, The Beginnings of New England, 25-30.)

2 John Fiske, Civil Government in the United States, 64-65. 
who again used a standing army to enforce their law for levying taxes against the will of those taxed. Thus, the outbreak of the Revolution found our ancestors, North and South, not only inheriting the hatred of a standing army, through generations of their own forebears, but at the instant confronted with a standing army as the instrument of the oppression which they were determined no longer to tolerate. Detestation of the word army was not alone an inherited prejudice, but a vital fundamental principle in the political faith of the day.

Such a prejudice, founded originally on justice, is slow to die. It survived long after the conditions which gave rise to it had ceased to exist. It has been slowly expiring in this country during the last hundred years, but it can hardly yet be called extinct. The debates in Congress at the last reorganization of the army in 1901 contain much of the same oratorical declamation about standing armies and the destruction of the liberties of Greece and Rome that Macaulay ${ }^{1}$ so graphically narrates in his account of the debate in Parliament in 1697.

On the other hand, the militia in England antedated the regular army by at least one thousand years; it was the Militia in part of the local government, and although derided in Dryden's witty verse ${ }^{2}$ it was always popular with the great body of the English people. It was essentially the same in the sixth century as in the seventeenth, and again in the nineteenth; its members were by turns fishermen, husbandmen, judges and warriors; they followed the

${ }^{1}$ History of England, V, 54 . Debate on the mutiny act.

2 "Mouths without hands, maintained at vast expense,

In peace a charge, in war a weak defence.

Stout once a month they march, a blustering band, And ever but in time of need at hand."

-DrYden, "Cymon and Iphigenia." 
Popularity of the Militia in the American Colonies

Origin of the Continental Army

June 15

June 30 trade of soldier, not as their chief occupation, but as incidental and subordinate to some other occupation by which they gained food, shelter and clothing. Their service was voluntary, although-for the able-bodiedthe liability to service was universal; they elected their own officers; they were part of the people, and not a class apart. These ideas were also brought to America in the seventeenth century. Belief in the militia and reliance upon its sufficiency were as important a part of the creed of the early settlers as was their hatred of an army. The militia was organized in every Colony as soon as the government was established, and was as essential a part of the governing machinery as the town meeting in New England or the county court in Virginia. ${ }^{1}$ It performed its part, on the whole, perhaps, satisfactorily, in the numerous Indian wars and in the French wars. It was the only military system indigenous to the Colonies; an army was the system employed by the "tyrant," George III.

Naturally, when the Revolution broke out the first reliance was upon the militia; but when the battles of Lexington and Concord brought a realization of how serious the struggle was going to be, the word "army" came to be used. Massachusetts and other New England Colonies began to raise their several armies and concentrate them at Boston; and in June, 1775, the Continental Congress took them over as a Continental army, appointed Washington its commander-in-chief and adopted rules and regulations for its government. ${ }^{2}$ A form of enlistment was agreed upon which prescribed that the term of service was to be "for one year, unless sooner discharged." 3

1 John Fiske, Civil Government in the United States, 16-67.

2 Jour. Cont. Cong., II, 90-111.

${ }^{3}$ Ibid., II, 91. 
This legislation was framed upon the Mutiny Act of 1697, which limited the existence of the British army to one June 14 year, and which had annually been re-enacted. Congress evidently thought that the liberty of the people might be subverted quite as well by a standing army as by George III, and determined to retain the right to disband it at any moment. But it soon became evident that the danger was not that of having a permanent army, but of having no army at all. Congress fixed the strength of the new Nov. 4 army at 20,372 officers and men ${ }^{1}$ but by December 31 , only 9,650 had enlisted ${ }^{2}$ and of these large numbers were absent. On the same date the term of service of the old army expired. It became necessary to call on the militia for temporary service in the attack on Dorchester Heights in March, 1776. Congress attempted to remedy the lack of enlistments by calling on the various Colonies to furnish a certain number of battalions for the Continental army, for service until the end of the year, and various resolutions to this effect were passed between January and September of $1776 .^{3}$ The response was not alto- Sept. 16 gether encouraging, and then Congress adopted a resolution" "that eighty-eight battalions be enlisted as soon as possible, to serve during the war, unless sooner discharged"-that each State furnish a certain quota; that a bounty of twenty dollars be given to each non-commissioned officer and private; that a grant of land be made to each officer and soldier who shall engage for the war; and that the appointment of all officers below the grade of general be left to the States. Still the enlistments were not satisfactory, and in November two reso-

1 Jour. Cont. Cong., III, $321 . \quad{ }^{2}$ Sparks, III, 220.

s Jour. Cont. Cong., IV, 29, 47, 99, 237, 357, 412; V, 486, 521, 598.

Ibid., V, 762. 
1776 lutions ${ }^{1}$ were adopted, the first requiring the enlisting officers to offer to recruits their choice of two forms of enlistment, one for the war and the other for three years; the second, a few days later, providing for only one form of enlistment which read "for three years or during the

Dec. 27

Washington Virtually Dictator

1778

Feb. 26 war." The army meanwhile was dwindling down to less than $5,000 \mathrm{men} ;^{2}$ thereupon Congress appointed Washington ${ }^{3}$ virtually dictator, authorized him to raise 16 battalions, in addition to those already resolved upon, and 3,000 light horse, 3 regiments of artillery and a corps of engineers; to appoint and discharge officers and fill all vacancies, to call on the States for militia, to impress supplies and to arrest and confine persons who refused to accept.Continental currency or were disaffected to the American cause.

The system of short-term voluntary enlistments thus came to grief before the Revolution had been much more than a year in progress. By Washington's personal efforts more than from any other cause, acting under any one of the many resolutions of Congress, the Continental army was maintained with varying strength from 6,000 to 10,000 men, and the militia of the various States came from time to time to help out for a few weeks in an emergency. Congress continued to pass resolutions throughout the year 1777, ${ }^{4}$ calling on the States to furnish their quota, but without much effect; and after a conference of a committee with Washington at Valley Forge it resorted to the draft. The states were "required forthwith to fill up by drafts, from their militia or in any other way that shall be effectual their respective battalions

${ }^{1}$ Jour. Cont. Cong., VI, 945, 971.

3 Jour. Cont. Cong., VI, 1045; Upton, 30.

${ }^{4}$ Upton, 25-32. ${ }^{2}$ Sparks, III, 225.

5 Jour. Cont. Cong., X, 200. 
of Continental troops." Having no power to enforce its 1778 decree, this resolution of Congress had no more effect than its predecessors, but Washington's personal appeals, combined with the news of the French alliance, succeeded in bringing out enough men to carry on the war.

It continued in this way to the end, Congress passing 1783 futile resolutions and Washington raising men and carry- sept. 3 ing on the war by the mere strength of his personal character. The treaty of peace was signed in 1783 and in the 1784 following year the army was disbanded, ${ }^{1}$ except eighty June 2 soldiers retained to guard the public stores at Fort Pitt and West Point.

The total number of enlistments had been $395,858,{ }^{2}$ and the maximum force in the field at any one time about 35,000 , or one in eleven of the enlistments.

We had succeeded in our main purpose of achieving waste and independence, and we had accomplished this without a standing army, and by means of short and numerous enExtravagance of the Revolution listments, large bounties and grants of lands. The waste and extravagance were repaired a few years later by the financial genius of Hamilton. The enormous pension roll ${ }^{3}$ was easily provided for from the resources of a land of rapidly developing wealth. Public sentiment was confirmed in its opposition to a standing army and confidence in the efficacy of untrained volunteers and militia was still further strengthened. The one man to whom success was due, and who achieved it, not because but in spite of our defective military policy, thought differently. Washington's opinions on the subject are worthy of careful study even at this late day, for his judgments

1 Jour. Cong., IV, 433; Upton, 69.

2 Upton, 58.

3 Total Revolutionary pensions during 126 years (1783 to 1908), $\$ 70,000,000$. Report Com. Pensions, 1908, 12, 21 . 


\section{MILITARY POLICY OF THE UNITED STATES}

1784 were the result of long deliberation and were of almost miraculous accuracy. He had seen service in the Indian and French wars before he came to take command at Cambridge in 1775. His knowledge of what took place between that date and 1783 was unrivalled. He was pre-eminently qualified as a witness.

His writings on the subject during those eight years, to Congress, to the State authorities and to personal friends, form no inconsiderable part of the twelve volumes edited by Sparks. A few of the most pertinent of those addressed to the President of Congress are here quoted.

February 9, 1776:" "To expect the same service from raw and undisciplined recruits as from veteran soldiers is to expect what never did and perhaps never will happen."

September 24, 1776:" "To pláce any dependence upon militia is assuredly resting upon a broken staff. . . . The jealousy of a standing army, and the evils to be apprehended from one, are remote and, in my judgment, situated and circumstanced as we are, not at all to be dreaded; but the consequence of wanting one, according to my ideas formed from the present view of things, is certain and inevitable ruin."

December 20, 1776:" "Short enlistments, and a mistaken dependence upon militia, have been the origin of all our misfortunes and the great accumulation of our debt."

August 20, 1780:" "Had we formed a permanent army in the beginning, ... . we never should have had to retreat with a handful of men across the Delaware in 1776,

${ }^{1}$ Sparks, III, 279; Upton, $11 . \quad{ }^{2}$ Sparks, IV, 113-115; Upton, 16.

${ }^{3}$ Ibid., IV, 234.

I Ibid., VII, 162; ibid., 53. 
trembling for the fate of America; ... we should not have been the greatest part of the war inferior to the enemy, indebted for our safety to their inactivity, enWashington's during frequently the mortification of seeing inviting opportunities to ruin them pass unimproved for want of a force which the country was completely able to afford, and of seeing the country ravaged, our towns burnt, the inhabitants plundered, abused, murdered, with impunity, from the same cause."

September 15, 1780:" "Regular troops are alone equal to the exigencies of modern war, as well for defence as offence, and whenever a substitute is attempted it must prove illusory and ruinous."

It will be observed that in these letters Washington addressed himself solely to the question of the moment: the proper method of organizing an army for carrying on the war. He said nothing about the propriety of maintaining an army in time of peace. In a letter ${ }^{2}$ to John Banister, of Virginia, delegate in Congress, written from Valley Forge on April 21, 1778, Washington admits the justice of the jealousy of a standing army in time of peace. His words are: "The other point is, the jealousy," which Congress unhappily entertain of the army, and which, if reports are right, some members labor to establish. You may be assured, there is nothing more injurious or more unfounded. This jealousy stands upon the commonly received opinion, which under proper limitations is certainly true, that standing armies are dangerous to a state. The prejudices in other countries have only gone to them in time of peace, and these from their not having any of the ties, the concerns or inter-

${ }^{1}$ Sparks, VII, 205 ; Upton, 54.

${ }^{2}$ Ibid., V, 328; ibid., 38.

${ }^{3}$ Italics as in Sparks. 


\section{MILITARY POLICY OF THE UNITED STATES}

1784 ests of citizens, or any other dependence, than what

Washington's Opinions

1783 flowed from their military employ; in short, from their being mercenaries, hirelings. It is our policy to be prejudiced against them in war, though they are citizens, having all the ties and interests of citizens, and in most cases property totally unconnected with the military line."

The final word of Washington, as general-in-chief, on military policy was given in the address ${ }^{1}$ which he sent to the governors of the States from Newburg about six months prior to resigning his commission. He evidently thought it either useless or unwise to advocate a standing army in time of peace, and therefore argued in favor of making the militia as effective as possible. He stated that there were four things "essential to the well-being, I may even venture to say to the existence, of the United States as an independent power," and one of them was "the adoption of a proper peace establishment." His opinion on this was as follows:" "The militia of this country must be considered as the palladium of our security, and the first effectual resort in case of hostility. It is essential, therefore, that the same system should pervade the whole; that the formation and discipline of the militia of the continent should be absolutely uniform, and that the same species of arms, accoutrements and military apparatus should be introduced in every part of the United States. No one, who has not learned it from experience, can conceive the difficulty, expense and confusion which result from a contrary system, or the vague arrangements which have hitherto prevailed."

While these recommendations were never carried into effect until 120 years after they were written, to wit, after the passage of the Militia Act of 1903, and while

${ }^{1}$ Sparks, VIII, 443; Upton, 68.

${ }^{2}$ Sparks, VIII, 450. 
each succeeding war has found us at the outset with different systems of formation and discipline, and different kinds of arms, accoutrements and military ap- $\begin{gathered}\text { Powers of } \\ \text { Congress }\end{gathered}$ paratus in the militia of the various States, yet these views of Washington were adopted in the Constitution in 1787, and have ever since been and now are the fundamental law of the land. As to the navy, the Constitution gives Congress power "to provide and maintain a navy," which evidently implies a permanent and continuing force; but as to the army the power of Congress is "to raise and support armies, but no appropriation of money to that use shall be for a longer term than two years," which equally implies a temporary force raised for war or other emergency.

Congress is further given power," "to make rules for the government of the land and naval forces, to provide for calling forth the militia to execute the laws of the Union, suppress insurrections and repel invasions; and to provide for organizing, arming and disciplining the militia, and for governing such part of them as may be employed in the service of the United States, reserving to the States, respectively, the appointment of the officers and the authority of training the militia according to the discipline prescribed by Congress." In order to emphasize still further the basis of the military policy, Congress at its first session passed an amendment ${ }^{2}$ to the Constitution, which was promptly ratified by the States, reciting that "a well-regulated militia" is "necessary to the security of a free State."

The English tradition, originating in the tyranny of the Stuarts more than 200 years before, was thus em-

${ }^{1}$ Constitution of the United States, I, VIII, 12, 13, 14.

${ }^{2}$ Ibid., Second Amendment. 
1787 bodied in our fundamental law. The army was to exist on sufferance for no longer a period than two years. Our main reliance was to be on the militia and on such armies as could be improvised when war breaks out.

Militia Act of 1792
Continued Prejudice against a Standing Army
It will be observed, however, that it was to be a "wellregulated militia"; and during the eight years of his presidency Washington made recommendations in each of his annual messages in favor of measures to make the militia a really effective force. The only result was the passage of the Militia Act of $1792,{ }^{1}$ which remained in force for $\mathbf{1 1 1}$ years, although it was obsolete a few years after it was enacted. In his message of $1793^{2}$ Washington called attention to its many defects, and again pressed upon Congress "the necessity of placing ourselves in a condition of complete defence. ... The United States ought not to indulge a persuasion that, contrary to the order of human events, they will forever keep at a distance those painful appeals to arms with which the history of every other nation abounds. . . . If we desire to secure peace, it must be known that we are at all times ready for war." In his message of 1794 he called attention to the "striking defects" in the militia law and resulting "extraordinary expense and waste." $\mathrm{He}$ referred to the subject again in 1795, and in his last message in $1796^{3}$ he particularly advocated the establishment of a military academy to preserve and transmit a knowledge of the military art, which he considered "of great moment to the security of a nation."

These appeals, however, were all unsuccessful. The memory of the Stuarts and of George III was still comparatively fresh in the minds of the people, and the

1 Mil. Laws, 95; Upton, 84.

${ }^{2}$.Mess. Presidents, I, 140.

${ }^{3}$ Mess. Presidents, I, 166, 184, 202. 
prejudice against a standing army was not to be over1787 come even by the arguments of the man who had gained, almost single-handed, their independence.

With the close of the Revolution, as already stated, the army was disbanded. Thirty years passed before we again had a serious war. In the meantime there were insurrections, such as Shay's Rebellion in Massachusetts in 1786, and the Whiskey Rebellion in Pennsylvania in 1794; Indian wars, such as Harmar's Miami expedition in 1790, St. Clair's campaign of 1791 and Wayne's campaign of 1794; the probability of war with France in 1798. ${ }^{1}$ These emergencies were met, partly by the militia and partly by volunteer armies raised for three years, and by a small but slowly increasing permanent force of regulars. This latter originated in a force of 700 men raised for service against the Indians in 1784, Origin of the U. S. Army continued for three years in 1785, again extended for June 2, 1784 three years in $1787^{2}$ and finally recognized by the First April 1, 1785 Congress $^{3}$ as "the establishment for the troops in the oct. 3, 1787 service of the United States." The army has existed Sept. 29, 1789 continuously from that day to the present, with increasing numbers, and with reorganizations in 1790, 1792, $1795,1798,1802,1808,1812,1815,1821,1838,1842,1846$, $1855,1861,1866,1870,1874,1898,1901-o r$, on an average, once in six years.

In January, 1812, when war with Great Britain seemed war of 1812 inevitable, the army consisted, under the laws of 1802 and 1808, of 11 regiments. By successive acts, ${ }^{4}$ Congress increased this as follows:

January 11, 1812, to 24 regiments.

${ }^{1}$ Upton, 71-77, 79, 83, 86, 87.

2 Jour. Cong., IV, 434, 493, 785; Upton, 69, 71,

${ }^{3}$ Mil. Laws, 87; Upton, 75.

Mil. Laws, 212, 230, 238, 250; Upton, 95, 123. 


\section{MILITARY POLICY OF THE UNITED STATES}

1812

Second War with Great Britain

Feb. 6

April 10

June 26, 1812, to 32 regiments.

January 29, 1813, to 51 regiments.

January 27, 1814, to 54 regiments.

The authorized strength of the latter was about 63,000 men.

But recruiting was always slow. The actual force varied from one-quarter to one-half of that which the law authorized. Volunteers were not called for, but the President was "authorized to accept" 1 not exceeding 30,000 volunteers. They did not come forward, the total number during the entire war being only about $10,000 .^{2}$ The militia was called out, ${ }^{3}$ but not exceeding 100,000 men and for a period not longer than six months. Congress now possessed the power, which the Continental Congress lacked, to enforce its laws, but it did not exercise that power. All the evils of the Revolution were repeated in perhaps aggravated form: short enlistments, successive levies of raw troops, enormous bounties, extravagant grants of lands and liberal promises of pensions. The rolls of the Pension Office show that 527,654 ${ }^{4}$ men were in service, most of them for periods of less than six months and more than half of them for less than three months. Not more than 25,000 , or one in twenty, were in the field at any time. The Pension Office is still paying pensions to the widows of soldiers of the War of 1812 (338 in number), and the total pensions of that war have amounted to nearly $\$ 46,000,000 .^{5}$

1814

Refusal to Furnish Militia

The military operations, as might be expected, were far from creditable; some of the militia refused, at critical periods, to cross the frontier. The governors of Massachusetts and Connecticut refused to call forth the

${ }^{1}$ Mil. Laws, 215; Upton, 95.

${ }^{3}$ Ibid., 222.

Ibid., 137.
Upton, 137.

5 Com. Pensions, 1910, 11, 27. 
militia of those States, reserving to themselves the right 1814 to determine when the exigency provided for in the Constitution and in the Act of Congress of 1795 had arisen. The Supreme Court of Massachusetts sustained them in this contention, and the question remained in doubt until 1827, when the Supreme Court of the United States decided that it belonged exclusively to the President to judge when such exigency arises. ${ }^{1}$

As soon as the war was over the army was reduced to Mar. 31815 $10,000 \mathrm{men}^{2}$ and six years later to $6,000 \mathrm{men}^{3}{ }^{3}$ John C. Mar. 21821 Calhoun was then Secretary of War. He held the position during the eight years of Monroe's administration, from 1817 to 1825, and next to Elihu Root was the ablest administrator among the fifty or more individuals who have filled that important office. Congress called upon him for two reports on the army, which he made in December, 1818, ${ }^{4}$ and December, 1820. In these he discussed in Calhoun's the most comprehensive manner the purposes for which Reports we maintain an army, its relation to our political principles, its strength, organization, equipment, emoluments, rations and clothing. He pointed out the terrible price which we had paid in 1812 in consequence of the lack of a proper military establishment and of suitable preparation in the preceding years; showed that "however remote our situation from the great powers of the world, and however pacific our policy, we are, notwithstanding, liable to be involved in war; and to resist, with success, its calamities and dangers, a standing army in peace is an indispensable preparation." He further stated that "to suppose our militia capable of meeting in the open field the regular troops of Europe would be to resist the

1 Martin vs. Mott, 12; Wharton, 19; Upton, 96-97.

${ }^{2}$ Mil. Laws, $266 . \quad{ }^{3}$ Ibid., $306 . \quad{ }^{4}$ Burnside, 139, 144; Upton, 145. 
most obvious truth and the whole of our experience as a nation"; and argued that "if our liberty should ever be endangered by the military power gaining the ascendancy, it will be from the necessity to retrieve our affairs, after a series of disasters, caused by the want of adequate military knowledge." 1 He laid down the fundamental proposition that "at the commencement of hostilities there should be nothing either to new-model or to create: the only difference between the peace and the war formation of the army ought to be in the increased magnitude of the latter, and the only change in passing from the former to the latter should consist in giving to it the augmentation which will then be necessary. It is thus, and thus only, the dangerous transition from peace to war may be made without confusion and disorder." The staff should be completely formed in time of peace and the organization of the line such that when hostilities begin "the force may be sufficiently augmented without adding new regiments or battalions." 2

In these documents, so remarkable in breadth and foresight, Calhoun followed to some extent the principles formulated by Scharnhorst in Prussia after the battle of Jena. He anticipated by more than a generation the system of expansion in war which has since been adopted for all European armies, and for which this country had to wait more than eighty years, during the greater part of which these principles were unsuccessfully advocated by army officers, until the genius and persistence of Mr. Root persuaded Congress to adopt them in the legislation of 1901-3.

Upon these principles, including especially "the desire to avoid creating new regiments with raw, inexperienced

${ }^{1}$ Burnside, 145.

${ }^{2}$ Burnside, 146; Upton, 149. 
officers at their head in time of war," Calhoun worked 1818 out a complete scheme of organization for an army of 544 officers and 6,391 men in peace, to be augmented to 832 officers and 18,200 men in war, without the formation of any new regiments. ${ }^{2}$

His wise words fell on deaf ears. Congress was then in the midst of the intensely exciting debate which resulted in the "Missouri Compromise." Calhoun's report apparently received no attention in Congress; there does Feb. 27 not seem to have been any debate on it; McMasters makes no reference to the subject; von Holst does not mention it in his biography of Calhoun. The law, as March 2 passed, simply reduced the army to 4 regiments of artillery, 7 regiments of infantry and a certain number of staff officers; the companies were small, each containing only 42 privates, and the entire authorized force was 542 officers and 5,642 men. ${ }^{3}$ No provision was made for augmenting the enlisted strength in time of war or other emergency. The old reliance upon militia and untrained levies was still the popular idea.

No change of any importance was made in the army during the next seventeen years, except the formation of a regiment of dragoons, ${ }^{4}$ now the 1st Cavalry. The actual strength was, however, at all times less than what the law authorized. In November, 1835, the authorized strength, ${ }^{5}$ including the dragoons, was 7,198 and the actual strength 3,888 .

In 1835 we became involved in the Florida war against the Seminole Indians, which proved a very serious affair, The Florida lasting more than seven years. The army was altogether

1 Burnside, 146.

Ibid., 217.

'Upton, 162.
2 Burnside, 157.

- Mil. Laws, 329; Upton, 161. 
1333 insufficient in numbers to cope with it; instead of augmenting its enlisted strength, as Calhoun had advised, the Florida militia was called out and Colonel Clinch, commanding the few hundred regulars on duty in Florida, was authorized to call on the governors of South Carolina, Georgia and Alabama for the militia of those States. The President was "authorized ${ }^{1}$ to accept" volunteers not exceeding 10,000 men "to serve six or twelve months." The regular army was subsequently ${ }^{2}$ increased by one more regiment of infantry and an addition of 16 privates to every company of artillery and of 38 privates to every company of infantry. This increased the authorized strength to $12,539^{3}$ and the actual strength to perhaps 9,000 .

The greatest number of men in the field at any one time was in November, 1837, when they numbered 5,025 regulars and 4,454 volunteers and militia. ${ }^{4}$ The rolls of the Pension Office show that during the seven years of this war the total number of men in service was $61,269^{5}$ of whom the greater number served for three months or less. It was a repetition on a smaller scale of the methods of the Revolution and the War of 1812; and it should be remembered that the Indian warriors against whom these 60,000 or more men went out for a few days numbered only about $1,200{ }^{\circ}$ The waste and extravagance of such methods are in sharp contrast with the effective work done by the small but well-trained army in the Indian campaigns after the Civil War.

The jealousy of a standing army was still a living principle, and Andrew Jackson undoubtedly expressed

${ }^{1}$ Mil. Laws, 336; Upton, 168.

${ }^{3}$ Burnside, 219.

5 Upton, 190.

${ }^{2}$ Mil. Laws, 341; Upton, 181-183.

4 Upton, 175.

- Ibid., 194. 
the opinions of a majority of his countrymen when in 1835 his seventh annual message as President, in December, Jackson's $1835,{ }^{1}$ he spoke of "the necessity of an efficient organizaOpinions tion of the militia," and defined our military policy in these words: "To suppress domestic violence and to repel foreign invasion, should these calamities overtake us, we must rely in the first instance upon the great body of the community whose will has instituted and whose power must support the government. A large standing military force is not consonant to the spirit of our institutions nor to the feelings of our countrymen, and the lessons of former days and those also of our own times show the danger as well as the enormous expense of these permanent and extensive military organizations." In the message of $1836,{ }^{2}$ however, his views were slightly modified. "While the necessities existing during the present year for the service of militia and volunteers have furnished new proof of the patriotism of our fellowcitizens, they have also illustrated the importance of an increase in the rank and file of the regular army. . . . In this connection it is also proper to remind you that the defects in our present militia system are every day rendered more apparent."

His successor, President Van Buren, in his message of $1837,{ }^{3}$ spoke of "the necessity of increasing our regular forces; and the superior efficiency, as well as greatly diminished expense of that description of troops, recommend this measure as one of economy as well as of efficiency." But he hastened to add: "It is not, however, compatible with the interests of the people to maintain in time of peace a regular force adequate to the

1 Mess. Presidents, III, 170.

Ibid., III, 254.

${ }^{3}$ Ibid., III, 390. 


\section{MILITARY POLICY OF THE UNITED STATES}

1837 defence of our extensive frontiers. In periods of danger and alarm we must rely principally upon a well-organized militia, and some general arrangement that will render this description of force more efficient has long been a subject of anxious solicitude."

In subsequent messages ${ }^{1}$ Van Buren referred, with diminishing interest, to the necessity of an efficient organization of the militia; but nothing was done. The subject excited no popular interest until the outbreak of the war with Mexico.

1842

Aug. 23

1846

War with Mexico

When the Seminole war ended in 1842 the army was reduced from 12,539 to $8,613^{2}$ men, the reduction being made in the number of enlisted men in a company, and it so remained until 1846.

${ }^{1}$ Mess. Presidents, III, 497, 537. I Mil. Laws, 358; Upton, 193. 


\section{CHAPTER II}

\section{THE GRADUAL GROWTH OF THE REGULAR ARMY}

SEvENTY years had thus passed in which we had had 1846 two wars with Great Britain and numerous campaigns against the Indians. Throughout this period the popular faith in an untrained militia remained unshaken.

When, however, it became necessary to make preparations for the war with Mexico, slightly different ideas began to prevail. The President was authorized, by successive acts of Congress, for the first time, to "call for," as well as to "accept," volunteers, the number not to exceed 50,000 , and the term of service to be twelve months "or to the end of the war"; "to employ" the militia for not May 13 exceeding six months; to increase the number of privates in any company to 100 men; to organize a company of engineers; to raise a regiment of mounted riflemen; to May 16 raise a regiment of dragoons and nine more regiments of May 19 infantry, to serve during the term of the war and no 1847 longer. ${ }^{1}$ These various laws provided for an authorized Feb. 11 strength of 30,890 regulars and 50,000 volunteers. The volunteers first enlisted claimed their discharge at the end of twelve months, and a new force had to be enlisted; so that the total number of volunteers was 73,532. The rolls of the Pension Office show a total of regulars and volunteers of 104,284. The greatest num-

${ }^{1}$ Mil. Laws, 367-379; Upton, 203-206. 
1847

War with Mexico
1848

July 19

1850

June 17

1855

March 3

ber at any time under Scott's command was 13,500 and under Taylor, 7,000. These figures ${ }^{1}$ compare favorably with the corresponding figures in the Revolution and in the War of 1812. They show that the army in the field was nearly one-sixth of the total number of enlistments, whereas in the previous wars it had been only one-eleventh or one-twentieth. Considering the results accomplished, the number of men called out during the Mexican War was much smaller than in the previous wars. The benefit of military training was beginning to be felt, and the small armies of Scott and Taylor were very efficient. The Military Academy at West Point had sent out, from 1802 to 1847 , no less than 1,368 graduates, ${ }^{2}$ and of these 523 served in the regulars and 36 in the volunteers ${ }^{3}$ with the armies in Mexico. Scott, who had had personal experience of the wretched results due to untrained troops in the War of 1812 and the Florida war, generously attributed his success in Mexico to these West Point graduates, stating his "fixed opinion" that but for them the war would have lasted four or five years, with more defeats than victories, whereas with their help complete victory had been obtained "in less than two campaigns." 4

The close of the war brought the usual reduction-to 10,320 men: $:^{5}$ but the army was soon increased ${ }^{6}$ by adding to the number of privates in each company, equivalent for the whole army, about 4,400 men; and later by two regiments of cavalry and two of infantry, about 4,000 men, carrying the authorized total to 18,349. At no time, however, did the actual strength exceed $15,000{ }^{7}$

${ }^{1}$ Upton, 209, 215, 216.

${ }^{3}$ Centennial of the U. S. M. A., 629-630.

${ }^{4}$ Cullum, I, XI; Upton, 222.

${ }^{6}$ Upton, 223
${ }^{2}$ Cullum, II, 206.

'Mil. Laws, 223, 393.

${ }^{7}$ Upton, 224. 
With these exceptions there was no additional legislation 1861 until the outbreak of the Civil War.

The magnitude of this struggle was not underestimated. As in previous wars the militia was first called out; President's Proclamation, 75,000 men for three months. As soon as Congress convened this was supplemented by two laws, each cal- The Civil war ling for 500,000 volunteers, and a third law adding to July 22 the regular army 9 regiments of infantry, 1 of cavalry July 25 and 1 of artillery. These laws ${ }^{1}$ were all under debate July 29 at the time of the battle of Bull Run, and were passed July 21 under its influence. The enlistment of volunteers in a 1861 few months exceeded 700,000, ${ }^{2}$ about one in six of the able-bodied male population. It was a magnificent risCalls for Volunteers ing in mass of the Northern population. Had this vast host possessed military training, the rebellion might possibly have been quickly suppressed. But the "wellregulated" militia of the Constitution, uniformly armed and accoutred, trained and disciplined, as Washington had advised, and possessed of a thorough knowledge of the military art, did not exist. The training and knowledge had to be gained as the war progressed.

Enlistment in the regular army was not popular. Its total strength never reached $26,000,{ }^{3}$ or two-thirds of what was authorized, and of these a large number were stationed in the fortifications and on the Western frontier. The force available for the field was probably less than 10,000 , and most of these served in the "regular division," forming part of the 5th Army Corps. They formed an inconsiderable part of the great army by which the war was carried on.

The strength of the volunteer army on January 1,

1 War Records, 3, V, 606; Mil. Laws, 466, 471, 473.

' Ibid., 3, IV, 1264.

${ }^{3}$ Upton, 257. 
1862,' was about 528,000 men. The War Department in December, 1861, had directed that no more regiments be raised unless specially authorized, and on April 3 , 1862, had discontinued all recruiting. ${ }^{2}$ This was resumed by order of June 6,1862 , and it was soon evident that large numbers of men must still be raised in order to make up for the losses in the field. The governors of eighteen States thereupon joined in a letter to the President suggesting that he call for additional men,

July 1 and on July 1 Lincoln made a call for 300,000 men. More than $420,000^{3}$ were furnished. As the war went on further calls became necessary, the draft or conscription was authorized ${ }^{4}$ and finally the President was empow-

March 3 ered $^{5}$ to call for such numbers of men as the military service required. There were in all, between April, 1861, and December, 1864, eleven successive calls; six for volunteers for three years or the war; four for militia for three to nine months, and one for regulars for five years. The total number called for was $2,763,670$, and the number furnished was 2,778,304. ${ }^{\circ}$ There were a great many reenlistments, so that it is difficult to say how many individuals enlisted. The number was probably in excess of $2,100,000$. The enrollment of April, 1865, ${ }^{7}$ showed 2,245,063 able-bodied men at their homes. From this it would appear that the number of men available for military service in the Northern States was something more than $4,300,000$ and of these about $2,100,000$, or nearly one-half, were enlisted.

The national government was victorious, at a fearful sacrifice; the Confederacy was annihilated. That the

1 War Records, 3, I, 775.

s Ibid., 3, IV, 1265.

Ibid., 3, V, 636.

${ }^{7}$ Ibid., 3, V, 620.
Ibid., 3, V, 608.

' Ibid., 3, V, 611.

- Ibid., 3, IV, 1269. 
struggle would have been shortened and the loss in lives and treasure reduced if we had had a larger trained army at the beginning has often been asserted by military writers. This is at least open to doubt; for in such case the South would have had almost the same relative advantage as the North. The nature of the struggle was such that it could only be ended by the absolute destruction of the military strength of the Confederacy, and this could only be accomplished by the use of almost the entire strength of the loyal States. On the other hand, it is not open to dispute that the strength of the government was not employed to the best advantage, but was Civil War misapplied, with accompanying waste and extravagance almost equal to those of the Revolution and the War of 1812. The same defects appeared: short service, enormous bounties and grants of land and a gigantic pension roll ${ }^{1}$ destined probably to endure till the last quarter of the twentieth century.

It is believed that at no other time in the history of the world have so many as 2,000,000 men been brought into the military service by a single nation in the space of four years. The failure to realize the full value of so numerous a force, composed for the most part of such superb material, was chiefly due to the constant raising of new regiments of raw recruits and inexperienced officers instead of keeping the old regiments filled up to their full strength. The maximum force under arms at any time was about $970,000^{2}$ men, or the equivalent of 970 regiments. But the total number of organizations raised during the war was $1,952^{3}$ regiments, 36

1 The pension bills of recent years-more than forty years after Appomattox-have been about $\$ 155,000,000$, of which about $\$ 146,000,000$ are paid to the Civil War pensioners.

2 War Records, 3, V, 137, 1029.

Ibid., 3, V, 1029. 
1865 battalions and 900 independent companies; this gives a total equivalent of 2,050 regiments, or more than twice as many as were needed. Had the quota assigned to each State been a certain number of regiments, squadrons and batteries, instead of a certain number of men, with a requirement that these organizations be kept up to their maximum, and that the appointment of officers be limited to men who had seen at least six months of active service in the ranks, there is little doubt that the final result would have been accomplished in less time and with a smaller number of men than 2,000,000. This method was frequently advocated during the progress of the war, but always rejected on the ground that troops could not be raised except for new organizations and with new officers. We had to come to conscription in the middle of the war, and enforce it relentlessly for the remaining two years, and we shall doubtless have to do the same if we are ever again engaged in a war lasting more than two years. A conscription law will be no more odious, if it contains these salutary provisions which have received the approval of our greatest soldiers. ${ }^{1}$

Comparison with Previous Wars
It must be noted that there was a great improvement in the Civil War over any previous war in the relation of the number of troops in the field at any one time to the total number of enlistments. We have seen that in the

${ }^{1}$ In a series of marginal notes made by General Sherman on an article by the author, published in Journal of the Military Service Institution in 1883, he says: "There is no doubt that reinforcing by new regiments was bad in every sense, and that recruits should be sent to old regiments." The same opinion was more than once expressed by General Grant and by General Sheridan in conversations with the author. See also Sherman's Memoirs, Vol. II, 388: "I believe that 500 new men added to an old and experienced regiment were more valuable than 1,000 men in the form of a new regiment, for the former, by association with good, experienced captains, lieutenants and non-commissioned officers, soon became veterans, whereas the latter were generally unavailable for a year." 
Revolution and the War of 1812 this ratio was one in 1865 twenty, and in the war with Mexico, one in six; in the War of the Rebellion it was one in four. The enlistments were $2,778,304 ;^{1}$ in May, 1864 , there were 970,710 in service, of which $662,345^{2}$ were present for duty, in the field.

The return of the volunteer army to the occupations of peace has no parallel in history. The muster out Disbandment of the Volunbegan within three weeks of Lee's surrender, and by August, 1865, 640,806 had been discharged; by November, 800,963 ; by January, 1866, 918,722 ; by November, $1866,1,023,021 .^{3}$

The regular army had an authorized strength in April, 1866 $1865,{ }^{4}$ of 47,806 . It was reorganized ${ }^{5}$ so as to consist of July 28 10 regiments of cavalry;

5 regiments of artillery;

41 regiments of infantry;

4 regiments of veteran reserves;

1 battalion of engineers;

and the various staff corps. The total authorized strength was 80,258 , but the actual strength was $54,581 .^{\circ}$ In $1869^{7}$ the infantry regiments were reduced from 45

to 25 , bringing down the authorized strength to 55,618 March 3 and the actual strength to $37,383 .^{8}$

In 1870 the number of enlisted men was reduced to Reorganiza30,000 , and in 1874 to $25,000 .^{\circ} \quad$ There were no changes, Army of any importance in the organization or strength of the army until the war with Spain, twenty-four years July 15 later.

${ }^{1}$ War Records, 3, IV, 1269.

${ }^{3}$ Ibid., 3, V, 517, 1012.

s Army Register, 1867, 144a.

7 Mil. Laws, 1907, 540.

๑ Mil. Laws, 1907, 187; Burnside, 102.
${ }^{2}$ Ibid., 3, V, 497.

4 Army Register, 1865, $106 a$.

- Army Register, 1866, 150c.

${ }^{8}$ Army Register, 1869, 235 a.
1870

1869 
During the years 1874 to 1878 the question of the permanent organization of the army was studied by successive committees of Congress; and a large amount of testimony was taken which, however, resulted in no legislation except the reduction to 25,000 men. In 1878 a committee was formed of three senators and five representatives, to whom was referred "the whole subject-matter of reform and reorganization of the army."

1878 The report of this committee ${ }^{1}$ is a veritable mine of inDec. 15 formation on every essential fact connected with the history of the army during the preceding 100 years. General Burnside, then senator from Rhode Island, was its chairman. All of its members had served in the Civil War, one of them (Senator M. C. Butler, of South Carolina) as a major-general in the Confederate army. General Garfield, then leader in the House of Representatives, and soon afterward President, contributed two very thoughtful and instructive papers for its consideration. Prominent survivors of the Civil War, Hancock, McDowell, McClellan, Terry, Pope, Ord, Hazen, Hunt and others, were called upon to submit their views accompanied by a draft of a bill to carry them into effect. The chiefs of staff departments, Humphreys, Meigs, Townsend, Benet, Marcy, Alvord and McFeely, contributed exhaustive histories of their several departments and recommendations as to their proper organization and their relations to the Secretary of War and the commanding general. Most important of all, General Sherman, then general-in-chief, submitted a history of the army from 1776 to 1876, accompanied by elaborate statistical data, extracts from the writings of Washington and the reports of Knox, Dearborn, Calhoun,

${ }^{1} 45$ th Cong., 3d Sess., Senate report, 555. 
Cass and other secretaries of war, and of committees of 1878 Congress; and finally his own matured views as to our military policy and the proper organization of the army to carry it into effect. At that time General Emory Upton, one of the brilliant group of officers who attained the rank and command of a major-general within a few years of graduation from West Point in 1861, had just returned from a trip around the world, undertaken for the purpose of studying foreign military systems, and had written his book on "The Armies of Asia and Europe," to which the committee gave full consideration. He was then engaged upon his "Military Policy of the United States," which was not published until Mr. Root Upton's " Mili. tary Policy" was Secretary of War in 1904, but the voluminous data which it contains were available to the committee as well as his views upon the proper method of organizing our military strength, and the best system of tactics, or drill regulations.

These two documents, the report of the Burnside committee in 1878 and Upton's book on military policy, Burnside Report contain an encyclopædia of military information, extracted from hundreds of volumes of state papers and other archives not readily accessible. Nowhere else is there to be found so much original information relating to the army condensed into such comparatively small space. Full use has been made of these volumes in preparing this chapter, and I desire to express my grateful acknowledgment of them and to refer all students to them for fuller details.

The bill ${ }^{1}$ which the committee reported followed the recommendations of the distinguished soldiers who had given the committee their advice, in certain essential

${ }^{1}$ Burnside, 1. 
1878 features, as to which these latter were substantially in accord, viz., a regiment of three battalions in each of the arms, infantry, artillery and cavalry; the staff departments, instead of being officered by permanent appointments, were to be filled by detail of officers from the line, who would return to the line after the expiration of their detail, thus giving to line officers a knowledge of staff duties and to staff officers familiarity with the needs of the army. The number of enlisted men in a company was to vary according to the exigencies of the services as determined by the President, subject to appropriations by Congress, thus providing a flexible system with small companies in time of peace capable of immediate and large expansion in time of war; and there was to be a "general staff," of somewhat limited functions, such as those hitherto performed by the adjutant-general's and inspector-general's departments.

Report not Adopted

Lack of Popular Interest
These wise provisions, and others, were enacted into law more than twenty years later. The Burnside bill of 1878 failed to pass, and the elaborate labors of the committee, based upon the experience and advice of the successful leaders in the greatest war of modern times, and upon a careful study of the military systems of Europe, apparently went for naught. The reason was not far to seek. There was no popular interest in the subject. Without that no measures can be enacted in this country. The discharged soldiers, North and South, more than 2,000,000 in number, and constituting about one in four of the entire voting population, were weary of the name of war; they were engaged in building up the industries of the country, in laying the foundations of that material development which in the succeeding thirty years has astonished the world; they fondly hoped 
that we would never again be engaged in war. Many of the statesmen of the period, discarding the lessons of history, did not hesitate to predict with entire confidence that there never would be another war in this country, that we should never have occasion to attack another nation, and no other nation would ever dare attack us. They could see no need for an army outside of a small force to protect the settlers against the Indians on the ever-advancing Western frontier. As to its organization they were indifferent, considering it a matter of very minor importance as compared with the development of railways, the silver question, the Chinese problem, the disfranchisement of the negroes and other public questions then pressing for solution.

The final effort of the Burnside committee, the culmination of more than twelve years' discussion about the army, having resulted in no action, the subject was dropped. The only point upon which the legislators, representing public opinion as they always do, were agreed was that the army should not exceed $25,000^{1}$ men in numbers, and this was inserted as a proviso in the appropriation bill, re-enacted in succeeding years and then incorporated in the "Revised Statutes," as the permanent law.

Twenty years later war came suddenly and almost out of a clear sky, although its cause-the discontent of Cuba under Spanish rule-had been in existence for two generations and had more than once brought our relations with Spain close to the breaking-point. The generation of the Civil War had practically passed away, its passions had been largely forgotten, there were new leaders in Congress, new men coming to the front in the

${ }^{1}$ Mil. Laws, 1907, 187; Rev. Stat. of 1878. 
1898 army. Its faithful service under great hardship, its success in settling the Indian question, the aid it had rendered in building up the Great West, its thorough efficiency and the studious attainments of its officers had made for it a host of friends which it had never possessed at the outbreak of any previous war. When the law for raising troops to carry on the war came up in Congress, the latter did not hesitate to declare" that "The regular army is the permanent military establishment, which is maintained both in peace and war according to law." The law further provided that "The volunteer army shall be maintained only during the existence of war, or while war is imminent ... that all enlistments for the volunteer army shall be for a term of two years, unless sooner terminated, and that all officers and men composing said army shall be discharged from the service of the United States when the purposes for which they were called into service shall have been accomplished, or on the conclusion of hostilities."

March 8

This and other laws ${ }^{2}$ expanded the enlisted strength April 26 from 25,000 to 63,116 , by adding 2 regiments of artillery, making all regiments to consist of 3 battalions and 12 companies, and the companies to have 106 enlisted men in the infantry, 200 in the heavy artillery, 173 in the light artillery and 100 in the cavalry.

In the joint resolution ${ }^{3}$ which demanded that Spain relinquish its government of Cuba, the President was "directed and empowered to use the entire land and naval forces of the United States and to call into the actual service of the United States the militia of the several States, to such extent as may be necessary to carry these resolutions into effect." This was substan-

${ }^{1}$ Mil. Laws, 1907, $184 . \quad{ }^{2}$ Sec. War, 1898, I, 252-262. $\quad{ }^{3}$ Ibid. 
tially according to, precedent in previous wars. In the 1898 law passed two days later there was a more specific direction" and one entirely novel: "When it becomes War with necessary to raise a volunteer army, the President shall issue his proclamation stating the number of men desired, within such limits as may be fixed by law." The law then specified in detail how such volunteers were to be organized. It also authorized another novelty, the raising of volunteer troops, "possessing special qualifications," not from the States but "from the nation at large," not exceeding 3,000 men in all, the officers to be appointed under "regulations to be prescribed by the Secretary of War." A little later this was expanded so May 11 as to provide for "a volunteer brigade of engineers from the nation at large," and "an additional volunteer force of not exceeding 10,000 enlisted men possessing immunity from disease incidental to tropical climates," the officers of these troops to be appointed by the President and not by the governors of States. The President's first call for volunteers was for 125,000 men, and in April 23 order to be sure of getting enough men while the enthusiasm was still warm, this was followed by a second May 25 call ${ }^{3}$ for 75,000 men.

The President of the United States, William McKinley, had in his youth trudged through the long marches and fought in many battles of the Civil War; the Secretary of War, R. A. Alger, had also served in the same war; the adjutant-general, Henry C. Corbin, had not only had the same experience, but was a man of rare executive and administrative ability and of tireless energy. They used their utmost efforts, and with success, in persuading Con- Civil war not gress so to legislate that the mistakes of the Civil War

${ }^{1}$ Mil. Laws, 1907, 192.

¿Sec. War., 1898, I, 259. 


\section{MILITARY POLICY OF THE UNITED STATES}

1898 and our previous wars might not be repeated. It will be noticed that there was no limit except the President's discretion to the number of men to be called for; that national volunteers, officered by the President under regulations prescribing examinations as to their military qualifications, were provided for. Therefore, when the second call for volunteers was made, the rule was established and rigidly enforced that the recruits should be sent to fill up existing regiments from every State, and no new regiments were formed until this had been done.

The laws passed and the regulations established for carrying them into effect in 1898 are models for similar occasions hereafter. It should be noted, however, that the able-bodied population was then about $13,000,000$, and the number of men called for, about 250,000, was only one in fifty, instead of one in two as in the Civil War. It may be a question whether the principles established in 1898 can be carried out in a war making such a demand on our military strength as did the Civil War. There seems to be no ground to doubt that they can be, if the number of volunteers in the first call is sufficiently large, and if, in case volunteers do not respond, the conscription is immediately applied.

Prompt

There was no such difficulty in 1898. The number called for was ample, and the response was instantaneous, not only for the volunteer but also for the regular army. Within a month the regulars were increased to 44,125 , and the volunteers to 124,804 ; within ninety days, regulars to 56,258 and volunteers to $212,094 .^{1}$ These troops were all organized, armed, equipped and in the field within the dates named. When the peace protocol 
was signed, on August 12, recruiting was stopped; there 1898 were then 274,717 men in the field, of which approximately 59,000 were regulars, 16,000 United States volunteers, and 200,000 State volunteers. The army had numbered only 28,183 ' on April 1 . The number of Spanish regular troops surrendered at Santiago was 13,006 and at Manila about 13,500; 15,000 were dispersed at Santiago, and over $70,000^{2}$ were sent home from Havana as a result of the Santiago campaign. To have increased our military force by 1,000 per cent, and to have defeated, captured or dispersed the armies opposed to us-all within a period of about four months - shows what can be accomplished with our latent military strength when it is judiciously applied.

While the ratification of the treaty of peace with Spain was pending the insurrection broke out in the Philippines. Under the law the ratification of the treaty required the April 22 reduction of the regular army to its previous strength of about 28,000 men and the discharge of the entire volunteer force. This was done. Congress then enacted 1899 that the regular army might be maintained at not ex- March 2 ceeding $65,000^{3}$ men, and that 35,000 volunteers should be raised "from the country at large." These new troops 1898 were raised in the course of a few months, and all the National volunteers and a large part of the regulars sent to the Volunteers Philippines. The field officers were selected from the regular army on their efficiency records, and the company officers were chosen, under rigid examination as to their service and qualifications, solely from those who had served in the war against Spain. These volunteers took their part side by side with the regulars in suppress-

${ }^{1}$ Sec. War, 1898, I, 253-260. $\quad{ }^{2}$ Sargent, Campaign of Santiago, III, 1.

${ }^{3}$ Mil. Laws, 1907, 190, 200. 
1899

Philippine Insurrection
Elihu Root as Secretary of War

ing the Philippine insurrection. That they were the most efficient, the best disciplined and most thoroughly trained volunteers that were ever mustered into our service is generally conceded. The individuals had the same excellent qualities as the volunteers of the Civil War, but these "volunteers from the nation at large" were organized on a system immensely superior. It is not likely that this experience will be forgotten the next time there is occasion to call for volunteers. It is true that at the outbreak of the Civil War we discarded the experience of our previous wars and repeated the same mistakes. No other system had then ever been tried and proved. Now that a better system has been actually used, and the precedent established, it is probable that we shall adhere to it in similar emergencies hereafter.

The organized force of insurgents was defeated and dispersed by midsummer of 1900; a guerilla warfare continued for nearly a year longer, but practically ceased with the capture of Aguinaldo in March, 1901. Under the law ${ }^{1}$ the army was to be reduced in strength to what it had been prior to April, 1898, and all the volunteers were to be discharged prior to July 1, 1901 .

In the meantime, in August, 1899, Elihu Root had become Secretary of War. During the five years of his administration the army obtained those measures of reform and advancement for which its chief officers had been begging in vain for three generations; and the country at last saw its military establishment placed on a footing for which a few of its most far-sighted statesmen, Washington, Calhoun, Cass and others, had argued, equally without success. Congress finally adopted these measures chiefly in consequence of four successive annual

${ }^{1}$ Mil. Laws, 1907, 190. 
reports, 1899 to 1902 inclusive, ${ }^{1}$ of the Secretary of War, 1899 which for clearness of thought, brevity and lucidity of statement, have probably never been excelled in our state papers. Mr. Root had never had any military training or experience, even in a militia company; but he surrounded himself with the best military advisers, officers fresh from the experience of Cuba, the Philippines and China, and thoroughly familiar with our military history and the defects of our military system in the past. Having absorbed their ideas, weighed them and clarified them, rejecting some and accepting others, he then presented the subject to Congress in documents which read like the arguments in a great cause before the Supreme Court of the United States.

It fell to Mr. Root's lot to formulate and put into 1901 operation a permanent scheme of government for the Philippines and for Porto Rico, and a temporary government for Cuba, which was followed by evacuation on conditions which provided for our intervention in case of mishap (which happened within a few years), all in accordance with a general plan of which the outlines only had been suggested by President McKinley. The organization of this civil government was constructive statesmanship of the highest order, and the instruments for carrying his plans into effect were the officers and men of the army. Simultaneously with the development and solution of these insular problems, he took up the needs of the army and secured, between 1901 and 1903, the reorganization of the army, the formation of the general staff and the establishment of a "well-regulated" militia. He obtained the necessary appropriations for completing and arming our sea-coast fortifications, the construction 
of which had begun in 1888; he amplified and systematized the plan of education at the schools for infantry, cavalry and light artillery which had been established by Generals Sherman and Sheridan several years before, and enlarged the scope of instruction at the pre-existing schools for the heavy artillery and engineers; he founded the War College at Washington for advanced instruction of a limited number of officers; and finally, he organized the Army Medical School. He persuaded Congress to appropriate nearly $\$ 7,000,000$ to rebuild and enlarge the historic Military Academy at West Point, but for whose existence during three-quarters of the nineteenth century the military art in this country would have been lost; and he procured an increase in the number of cadets from 384 to 481 .

The arguments in the annual reports, by which these results were accomplished, are themselves so condensed that any summary of them is impossible. The key-note is the proposition, in the report for 1899, "that the real object of having an army is to provide for war" - a truism which singularly enough had been disregarded for many years.

Reorganization of 1901

Feb. 2
With this object in view it was provided ${ }^{1}$ that the army should consist of 30 regiments of infantry, 15 of cavalry, 1 of engineers, a corps of artillery (of size equal to 13 regiments) and the staff departments. The artillery was divided into two branches, the coast artillery and the field artillery, with a chief of artillery in charge of both. ${ }^{2}$ The number of officers was fixed at $3,996^{3}$

${ }^{1}$ Mil. Laws, 1907, 1048.

${ }^{2}$ By the act of January 25,1907, the field artillery was transferred to the line of the army and organized into six regiments; the coast artillery became a corps, under its chief, charged with the care and use of coast fortifications, including torpedoes and submarine mines.

${ }^{3}$ Mil. Laws, 1907, 1048-1060. 
and the enlisted strength was left to the discretion of the President, between 60,000 and 100,000. The advantage and economy of this flexible system have been fully utilized by successive executive orders, fixing the enlisted strength according to the necessities of the year and the appropriations of Congress; it has varied from 59,866 to $78,782 .^{1}$

As to the staff departments, it was provided ${ }^{2}$ that when a vacancy occurred in the position of chief of the corps or department, it should be filled by detail of any officer in the army, not below the rank of lieutenantcolonel, for a period of four years; and as to the other officers, those then holding permanent appointments were to retain them and be promoted according to seniority, but as vacancies occurred, they were to be filled by details from the line, for a period of four years, under such system of examination as the President should prescribe. From these provisions the engineer, judge-advocate and medical departments, for obvious reasons, were excepted; but as to all others the rule of details and consequent interchangeability of service in the staff and line was to prevail. The system has now been in operation for nearly ten years, more than fifty per cent of the officers in the seven other staff departments are detailed from the line and several hundred officers have already served their detail in the staff and returned to the line. The eternal bickering and mutual complaints between the staff and line which filled the air for thirty years prior to the passage of this law are no longer heard. The army is a homogeneous body, each part understanding and in touch with the others.

The law also provided for the organization of battalions,

'Army Registers, 1903-1910, 'Mil. Laws, 1907, 1061. 
1903 of which there are now seven, of Philippine scouts, with majors and captains detailed from the army and lieutenants appointed from officers and enlisted men who had served in the war with Spain; also for a Porto Rico regiment, with field officers detailed from the army and captains and lieutenants appointed from veterans of the war with Spain or citizens of Porto Rico-the latter for four years, but with provision for reappointment and promotion if found qualified. There are now ten native officers in this regiment.

Feb. 14

The establishment of the general staff is a landmark in our military history. Its purpose was to prevent the recurrence of such confusion in the transport and supply departments as had accomplished the assembling of troops at Tampa in 1898, which was then fresh in the public mind but was by no means unprecedented. The law ${ }^{1}$ provided for the selection by the President of one of the general officers, to be called chief of staff, and 4 colonels, 6 lieutenant-colonels, 12 majors and 20 captains, all for the period of four years, unless sooner relieved. The chief of artillery was to be an additional member of the staff.

The duties of the general staff are briefly but clearly defined in the law:" "To prepare plans for the national defence and for the mobilization of the military forces in time of war; to investigate and report upon all questions affecting the efficiency of the army and its state of preparation for military operations; to render professional aid and assistance to the Secretary of War and to general officers and other superior commanders, and to act as their agents in informing and co-ordinating the action of all the different officers who are subject under the terms

${ }^{1}$ Mil. Laws, 1907, 1290.

'Ibid., 1907, 1291. 
of this act to the supervision of the chief of staff; and

to perform such other military duties not otherwise assigned by law as may be from time to time prescribed by the President." The officers "subject to the supervision of the chief of staff" are those of all troops of the line and of the ten different staff departments-the entire army, in fact. The chief of staff is also required to perform such duties as hitherto had been assigned by law to the commanding general of the army. They were only two in number, membership in the Board of Fortifications and the commissioners of the Soldiers' Home. The anomaly of a commanding general in time of peace attempting to exercise actual command, whereas the Constitution makes the President commander-in-chief and the statute designates the Secretary of War as his agent, thus disappeared, and with it the cause of endless misunderstanding and resulting inefficiency. It was succeeded by an efficient system under which one of the generals is selected as chief military adviser to the President and holds the position at the pleasure of the latter.

The merit of this law was soon tested. In September, 1906, it became necessary ${ }^{1}$ to send a force of 6,000 men to intervene in Cuba. Plans for such a contingency had been prepared long in advance. They were carried out with the smoothness and regularity of a drill on parade. The contrast to the confusion, extravagance and lack of efficiency in previous movements of our troops in an emergency was most striking. ${ }^{2}$

${ }^{2}$ Report War Dept., House Documents, Vol. 2, 1906, 458-459.

${ }^{2}$ While these pages are going through the press a still larger movement has been carried out; 20,000 men have been concentrated in Texas, without previous notice, in a period of nine days. Detailed reports are as yet lacking, but apparently the operation has shown great efficiency on the part of the general staff. 
It is the business of the general staff to be prepared for similar contingencies, which to the general public seem unexpected and improbable. All the world knows what the general staff did for Prussia in 1870. Our own general staff differs from that of the European armies in many particulars, but it is believed that it is adapted to our own requirements and will perform equally valuable service for us if a similar contingency should arise.

Of its many but important minor duties it is impossible to speak here in detail. They are fully set forth in regulations ${ }^{1}$ prepared by Mr. Root under date of August 3, 1903.

Militia Act of 1903

Jan. 21

The law" "to promote the efficiency of the militia" directed that the organization, armament and discipline of the militia should be the same as in the regular army, and provided the funds to make this effective. For the first time in all our history the militia now has the same arms, equipment, uniforms and drill as the regular army, and is equipped with tents, cooking apparatus and other material necessary to take the field at a moment's notice. The law further authorized the President in time of war or other specified emergency to call forth any part of the militia for a period not exceeding nine months; and he is not required to call upon the governor of a State, but he may "issue his orders for that purpose to such officers of the militia as he may think proper." Every officer and enlisted man thus called forth shall be mustered into the service of the United States, and for failure to present himself for such muster there are heavy penalties. In other words, when the emergency arises, the President may order any colonel to report on a fixed date with his regiment, and all its arms and equipment (which remain

${ }^{1}$ Sec. War, 1899-1903, 483.

${ }^{2}$ Mil. Laws, 1907, 1249. 
at all times the property of the United States), to a mus1903 tering officer, and forthwith that regiment becomes a part of the volunteer army, as defined and provided for in the law of 1898.

The militia law $^{\mathbf{1}}$ also requires a certain number of drills every year, provides for annual encampments and manœuvres in conjunction with regular troops, authorizes the detail of officers of the army for duty with it, affords safeguards for the issue and proper care of the arms and other property of the United States which are furnished to it and permits the attendance of any of its officers at any of the army schools, except West Point, with a view to their becoming officers of the army.

Encampments and joint manœuvres have been held Militia Act of under this law every year since 1904, with manifest ad1903 vantage not alone to the militia but also to the army.

The law goes to the utmost limit in carrying out the constitutional requirement of a well-regulated militia. Its only danger is that it may have gone so far as to discourage recruiting in the organized militia, commonly called the National Guard, the strength of which is about 120,000 men. Officers of the army as well as the general public are apt to forget the full significance of the fact that the National Guard receives no pay, that its only material compensation is exemption from jury duty, that its drills are habitually carried on at night after the day's work is over, that all its members are engaged in other avocations in which they gain their living, and that their military duties are necessarily subordinate to the chief occupation of their lives. All that the service has to offer them is the occasional use of armories for athletic or social purposes, the physical advantages

${ }^{1}$ Mil. Laws, 1907, 1249-1250. 


\section{MILITARY POLICY OF THE UNITED STATES}

1903 of military drill, the pleasure of handling fire-arms and becoming proficient in their use and the applause of the public at parades. As against this they are liable to be called away from their families, and their business, perhaps losing their employment, as many did in 1898, on the President's order for service for any period not exceeding their term of enlistment and at any point within or without the United States. To remedy this it has been suggested that service in the militia be paid. But this is of doubtful expediency, for many of the best and oldest regiments in the National Guard have existed for several generations solely from pride and esprit-de-corps. To convert them into paid organizations would be to destroy their traditions and change the whole character of their personnel.

It probably will work out in practice that in the seacoast cities, where about one-half of the older National Guard regiments are to be found, they will prove to be a most satisfactory support to the coast artillery. Even with the present organization of the army we have less than half the number of instructed men necessary to man the guns already in position. To serve in the forts at the guns, or to be stationed near the forts to defend them from a land attack, will not take the men far from their homes. Already several of the National Guard organizations have been changed from infantry regiments to coast artillery companies. They have their designated stations at certain of the ten-inch or twelve-inch guns in a fort within a few hours' ride by trolley-car or boat from their armories, and they have been drilling at these identical guns every summer for several years. That fort and their particular gun are as familiar to them as their own armories. That they could render ad- 
mirable service there in time of war does not admit of 1903 doubt.

The other half of the National Guard, located at points distant from the seaboard, would probably respond to an order for active service with less loss than the regiments in the larger cities. It is equipped as infantry, and except in case of extraordinary emergency would probably not be kept away from its home, involuntarily, for any great length of time.

The scheme formulated in Mr. Root's report for $1902^{1}$ embraced

1. A regular army of from 60,000 to 100,000 men;

2. A militia, trained and fully armed and equipped and subject to the President's order, of from 120,000 to 150,000 men;

3. A first volunteer reserve, composed of such portions of the organized militia as might volunteer for a longer period than nine months;

4. A second volunteer reserve, composed of officers and men who have had previous military service;

5 . Volunteers organized by the States, as in the Civil War.

He estimated the number available for immediate action, in the first four classes at 250,000 to 300,000 men, and stated that the number of the fifth class "has no limit, except the possibility of transportation and supply."

No legislation has yet been enacted in regard to the three classes of volunteers above referred to, although an act has been drafted ${ }^{2}$ under the direction of the general staff, and has been pending in Congress since 1909. This

${ }^{1}$ Sec. War, 1899-1903, 286.

${ }^{2}$ 61st Congress, 2d Session, Senate bill 4003. 
act is intended to provide in advance for the organization of the volunteer army, so that when war is imminent it would only be necessary for the President to state in his proclamation the number of men desired in each arm or corps. The act provides how they shall be organized and how many general and staff officers shall be appointed in proportion to the number of men called for. Briefly, the law contains the following essential provisions, viz., the period of service is to be for the war, unless sooner discharged; all officers of every grade are to be appointed by the President; the men received into service are to be taken as far as practicable from the several States and Territories in proportion to population; the organization, arms and equipment are to be identical with those in the regular army; all volunteer organizations are to be maintained as nearly as possible at their maximum strength by means, of recruiting depots established for that purpose; regular officers are to be assigned to all organizations not exceeding five to one regiment; and officers and men in the volunteer army are to be on the same footing as those in the regular service.

That these provisions are justified and demanded by our experience in previous wars does not admit of doubt, from the professional military stand-point. It is equally true that they run counter to various political considerations and to many deep-seated prejudices in favor of rights previously exercised by the governors of States. Whether these latter can be overcome to the extent necessary to enact these laws remains to be seen.

One other question, brought forward by Mr. Root in his first report of $1899,{ }^{1}$ is still pending in Congress; that

${ }^{1}$ Sec. War, 1899-1903, 61. 
is, the system of promotion. In every other military service in the world, and in every great corporate organization employing large bodies of men, the promotion of officers is based on relative merit and fitness determined by some specified board or other agency. In our army, below the grade of general officers, promotion is determined solely by seniority. Mr. Root proposed that one vacancy in three should be filled by selection under carefully guarded regulations so as to prevent favoritism. The great majority of officers opposed this so vigorously that for eleven years they have defeated it. As an alternative proposition the general staff has drafted a law, which has been pending in Congress for two years, based upon the principle of "elimination." If vacancies are less than a certain number in any grade during a certain number of years, then a definite number of officers in that grade are to be eliminated by retirement, the selections for elimination to be made by a board of officers under proper regulations. Such a measure would stimulate promotion, but would not accomplish the purpose of selecting the best men for command. When war comes and men's lives depend every day and every hour on the skill of the officers in command, then the rule of strict seniority is thrown to the wind; the purpose then is to select the best man, and no claim of vested right to promotion is considered or tolerated. The same principles should apply when, in time of peace, the army is preparing for war.

This chapter has already exceeded its intended length, summary and it only remains to summarize it. It has been my endeavor to show that our forefathers were imbued with an intense prejudice against a standing army in time of 


\section{MILITARY POLICY OF THE UNITED STATES}

peace and a supreme reliance upon untrained militia; that these prejudices resulted in enormous waste, extravagance and inefficiency in the Revolution and the War of 1812, and to a minor extent in the Mexican War, the Civil War and the war with Spain; that nevertheless a standing army was found to be necessary and has existed since the First Congress, gradually increasing in numbers and efficiency, and slowly, step by step, gaining the confidence of the people; that the strength of the army has varied from 50 to 120 per 100,000 of the population, or from 1 per cent to $2 \frac{1}{4}$ per cent of the "able-bodied male population," and its annual cost, exclusive of pensions, has been less than 1 per cent of our national wealth; and that finally, in this 135th year of our independence, we have an efficient army, and a militia with uniform arms, equipment, organization and drill, both respectable in numbers, though small as modern armies are counted, and both subject to the instant call of the President. We have built proper fortifications on our sea-coasts and have placed in them a reasonable number of modern high-powered guns.

More progress has been made in the improvement of our army during the last ten years than in all its previous history. The war with Spain, so brief in point of time, so slight as regards loss of life, has changed completely our relations to the rest of the world. It has brought us into close touch and sharp competition with the nations of Europe on one side and of Asia on the other; and with this competition the prospect of foreign war, which thirty years ago seemed so remote as to be negligible, is now a contingency that must be kept always in mind. Abuse of a disciplined regular army and praise of a patriotic untrained militia are no longer the popular 
cries with which demagogues in politics strive to catch 1903 votes. Measures to improve the efficiency of the army and to put the country in a proper state of defence and keep it so are no longer approved in the abstract and neglected in the concrete, but they receive the serious consideration of Congress, and this consideration leads to actual legislation.

Our military policy still remains, and is likely to remain, somewhat different from that of the nations of Europe. Enormous armies, conscription and universal military service seem not to be necessary with us. We still rely upon voluntary service; but universal liability to service is the law of the land, and conscription is in the background if volunteers are not sufficient. Above all, public opinion is beginning to appreciate the fact that untrained patriotism is not sufficient and that our chief reliance must be upon a military force trained in advance in time of peace for the immensely complex problems of war.

It would be a mistake on the part of our legislators to attempt to blink or dodge the fact that among the conPossibility of War ditions of our national life at the present time is the possibility of war with one or another great nation possessing a trained army of from 300,000 to $1,000,000$ men, with ample transport facilities for crossing the oceans which bound our coasts, and a powerful navy to protect such transports. If such a war comes, the attack on our coasts will probably precede the declaration of war.

It is a fallacy to argue that these oceans isolate and protect us from other nations. That might have been true when Washington gave his wise advice against entangling alliances; ${ }^{1}$ although England crossed the At-

${ }^{1}$ Sparks, XII, 231, 232. 
1903 lantic with 30,000 men in 1776 , the allies sent 60,000 men through the Mediterranean in 1854 and we moved 12,600 men across the Gulf of Mexico in 1847. In two of these expeditions the troops were carried in sailing ships, moving with uncertain speed, from 50 to 100 miles in a day, and each carrying from 200 to 250 soldiers. Now they would be carried in great steamers, with 3,000 to 5,000 troops on each, travelling at a certain speed of 400 miles or more every day. More than one great nation can assemble and embark an army much larger than our own in 10 days and cross the Atlantic in 10 days more, or the Pacific in 20 days. While our principal cities are protected by modern fortifications, yet there are long stretches of beach and several harbors on both coasts where a landing is feasible unless we have a mobile army strong enough to prevent it.

These are not theories, but the actual conditions which confront us in this twentieth century. That we should ultimately prevail in any such contest, owing to our enormous resources, our mechanical ingenuity, our fertility in expedients and, above all, the dominant character of our race, seems probable-unless our race is decadent, and if that be true then we shall perish. The race which came out victorious from the Civil War will not probably be subdued; but if it wins it will be at the end of a sacrifice which cannot be measured.

Such a contingency is among the possibilities under any circumstances; it goes with the conditions of our national life. If we are not prepared for it, it becomes not alone a probability but almost a certainty; for we are competing with all the world for the trade of the Orient and of South America, and we must so compete. 
If we abandon the competition our prosperity will come to an end. It is not to be expected that we shall abandon it, but rather that the trade rivalry for foreign markets which has recently begun will rapidly increase in the next few years. In such rivalry the potential causes of war are numerous and frequent.

The Venezuelan incident has shown that the ties which bind us to Great Britain are so strong that war with that country is improbable even under extreme provocation. But it is idle to deny that there are other nations which are jealous of our phenomenal growth. Their attitude toward us, however friendly it may have been in the past, is now by no means cordial, and at times seems like thinly veiled hostility. It is well to remember what Washington wrote in 1778:" "It is a maxim, founded on the universal experience of mankind, that no nation is to be trusted further than it is bound by its interest; and no prudent statesman or politician will venture to depart from it."

Some people say that the expression of such views Inadequate provokes war. The teachings of history prove that this $\begin{gathered}\text { Preparation } \\ \text { for } W a r\end{gathered}$ is not true, and that war comes to the nation that is not prepared for it. Especially is this true of a very rich nation, with abundant resources-unorganized. We have always been unprepared for war, and we have been at war one year in every seven since we declared our independence. We have a more efficient army and a more highly organized militia now than at any previous time in our history; but compared with the possibilities that confront us and the conditions which have resulted from the use of steam and electricity, we are about as unprepared now as at any previous time.

$$
{ }^{1} \text { Sparks, VI, } 110 .
$$




\section{MILITARY POLICY OF THE UNITED STATES}

It would seem to be incumbent upon those who are responsibile for our national legislation to study these facts, to forget the traditions which our Puritan and Cavalier ancestors brought over from England nearly three hundred years ago, to realize that what was wise in the days of the Stuart tyranny has no application in this twentieth century and to frame a military policy suited to the conditions under which we are now living. 


\section{APPENDIX}

The Medical Department can justly claim an equal share with the Ordnance Department and the Corps of Engineers in the valuable contributions to the advancement of science made by the army in the last ninety years, and particularly since the Civil War. Among them is the suppression of yellow-fever in the tropics, which is solely due to the efforts of the army surgeons, one of whom lost his life in the process. Aside from the loss of life, the paralysis of business throughout the Mississippi Valley and the coast of the Gulf of Mexico, which was an incident to such epidemics as that of 1878 at Memphis, produced financial loss many times greater than the entire cost of the war with Spain and the resulting acquisition of the Philippines. From such financial losses and the appalling loss of life from yellow-fever, we are henceforth, apparently, immune.

Moreover, it is reasonably certain that but for this great achievement of the Army Medical Corps and the sanitation introduced by Colonel Gorgas on the Isthmus, we should not have been able to construct the Panama Canal. Had we had such proportionate loss of life among the 45,000 or more laborers now working on the canal as attended the construction, by a much smaller force, of the Panama Railroad from 1849 to 1855 (where, as the phrase goes, a laborer was buried under every tie), or such loss of life as befell the French during their unsuccessful attempt to build the canal between 1883 and 1892 , there is little doubt that this would have created an adverse public sentiment sufficiently strong, when added to the sentiment against building the canal on other grounds, to have led to the abandonment of the entire project. 
General Wood, chief of staff, has kindly caused to be prepared by Lieutenant-Colonel J. R. Kean, Medical Corps U. S. A., a condensed statement of the facts in regard to the suppression of yellow-fever and the connection of the mosquito therewith. As the matter is one of world-wide importance, and has a distinct bearing on the enforcement of any military policy that the United States may decide upon, the statement is published in full, as follows:

\section{THE CONQUEST OF YELLOW-FEVER}

The military occupation of Cuba brought the army in confrontation with yellow-fever, a foe which had before been destructive to many invading expeditions in the Antilles and which at Santiago gave General Shafter's army a severe demonstration of its fatal and demoralizing power. Upon the recommendation of the surgeon-general, a commission was sent to Havana to study the question of its cause and prevention, a task upon which many distinguished scientists had labored in vain. Major Walter Reed, Surgeon, U.S. A., who was placed at its head, had recently overthrown the claim of the distinguished bacteriologist, Sanarelli, to have discovered the bacillus of yellow-fever, by demonstrating that this organism was a common one in the United States and having no causative relation to that disease. The other members of the commission were Acting Assistant Surgeons James Carroll, Jesse W. Lazear and A. Agramonte, the latter a Cuban by birth and the only member of the commission who had clinical experience with yellow-fever and was immune to it. The time was most opportune for such investigation, as the disease was at that time prevalent both in Havana and in the town of Marianao near the camp of the American troops, and it had become plainly evident that the energetic measures of the American military government to clean up the towns, disinfect and enforce other sanitary measures were without effect in preventing the spread of this mysterious disease. 
The transmission of malaria by a certain species of mosquito had recently been demonstrated by the English military surgeon, Major Ronald Ross. Dr. Carlos Finlay, of Havana, had, since 1881, stoutly maintained that yellow-fever was a mosquito-borne disease and had fixed accurately upon the species which was responsible, but his numerous experiments had failed to demonstrate the truth of his hypothesis, and it therefore received no more attention or acceptance from the scientific world than the vast number of other theories which had at one time or another been advanced with regard to this peculiar and dreaded disease. Dr. H. R. Carter had observed that when a non-immune person went into an infected house he became sick in 5 days or less, but that 15 or 20 days elapsed before a house became infected after a patient sick with yellowfever was carried into it and secondary cases appeared. Carter drew no inferences from this observation, but to Reed's mind it suggested that the difference between the period of incubation and that required to infect a building was due to the fact that the infective agent had to pass through a stage of development in some biting insect as an intermediate host, and he determined to investigate the mosquito theory of Finlay. The first attempts were tried secretly on Carroll and Lazear and other persons at the hospital of Columbia Barracks, but were failures owing to the same cause that had rendered negative Finlay's numerous and intelligent experiments on human beings, namely, that two conditions have to be satisfied for the transmission of yellow-fever: the mosquito, in order to become infected, must bite a patient during the first three days of the disease, and, second, the insect must be kept at least twelve days before it can transmit the infection. Meanwhile, during a temporary absence of Reed in the United States, mosquitoes in which both conditions were fulfilled were applied to Dr. Carroll and to a cavalry soldier, both of whom came down with yellow-fever, Carroll's case being very severe. These cases convinced Reed, but they were not sufficient to convert the scientific world, and it was evident that a series 
of fully observed and controlled cases was necessary to confirm and define the conditions of this momentous discovery. He went, therefore, to General Leonard Wood, the Military Governor of Cuba, to ask permission to conduct such dangerous experiments on human beings and for a sum of money to reward volunteers who should offer themselves for this perilous experience. General Wood promptly granted both with a ready appreciation of the importance of the matter which entitles him to no small share of the glory of the discovery. Havana was at that time full of Spanish laborers who had come to Cuba seeking employment, and who all anticipated sooner or later an attack of yellow-fever, an expectation in which they were not usually deceived. It was found easy to induce these men to submit to the bite of infected mosquitoes, although the consequences were carefully explained to them. They concurred in the opinion of the board that their chances of recovery were far better with the skilful care and good nursing of an army hospital than if the disease were contracted in the usual way amid the squalor and neglect of their accustomed surroundings. American soldiers of the hospital corps also came forward in abundance, so that it was no longer necessary for other members of the commission to offer themselves for experiment. Lazear, however, the member who had charge of the infecting of the mosquitoes, was bitten while so doing in the yellow-fever hospital in Havana and died of malignant yellow-fever. In the fall of 1900, after Lazear's death, a camp named after him was established about a mile from Columbia Barracks for the conduct of a series of experiments which, by precision of detail and rigidness of control, would admit of no uncertainty of interpretation and would be a perfect demonstration carrying conviction to every scientific and unprejudiced mind. Camp Lazear was established November 20 and the subjects for experiment were kept there under rigid regulations to exclude infection in any way except experimentally. As soon as taken sick the cases were taken to the isolation hospital of the barracks. One building was con- 
structed for mosquito experiments. It was carefully screened and contained a large room entirely divided across its centre by a partition of wire gauze which permitted circulation of air but not the passage of mosquitoes. In one side of this screen infected mosquitoes were let loose, and the individuals who went into that side were bitten and infected. On the other side of the screen, breathing the same air, slept and lived non-immunes who remained uninfected. This demonstrated that the mosquito, not the air, carried the infection. At some distance away another building was constructed into which were carried bedclothes and shirts worn by yellow-fever patients, some even soiled with black vomit and other discharges. In this room, of which the air was kept warm and moist, slept and lived 6 non-immune American soldiers for periods of ten days each during a period of two months. Acting Assistant Surgeon R. P. Cook underwent this repulsive experience with the first 2 soldiers, and although they daily handled and even slept in this presumably infected clothing, none of them contracted yellow-fever. Three of them afterward demonstrated their susceptibility by contracting the disease by the bites of infected mosquitoes. In these experiments 14 cases of yellow-fever were caused by infected mosquitoes of the genus Stegnomyia, 5 by injections of blood of patients in the first three days of their illness and 3 by injections of filtered blood serum, 22 cases in all, of which 15 were Americans and 7 were Spaniards. No deaths occurred except that of Dr. Lazear above mentioned. In a series of 10 experimental cases at Havana, however, conducted in 1901 by Gorgas and Guiteras, 3 proved fatal, 2 being Spaniards and 1 an American trained nurse, Miss Clara Louise Maas. These experiments demonstrated that

1. Bacillus Ictervides of Sanarelli does not cause yellow-fever.

2. Yellow-fever is carried by the mosquito, genus Stegnomyia.

3. That this mosquito cannot convey the disease until the twelfth day after biting the patient, and then retains the infective power for the rest of its life. 
4. Patients can transmit yellow-fever to the mosquito only during the first three days of the disease.

5. Yellow-fever is not communicable by clothing, etc.

Application was at once made of this knowledge by Major W. C. Gorgas, Health Officer of Havana, in February, 1901, and this dread disease was stamped out of Havana and Cuba for the first time in nearly two centuries. Between the years 1853 and 1900 it has caused 35,952 deaths in the city of Havana alone. The application at the Isthmus of Panama of the same knowledge, together with the administrative methods worked out in Havana, has enabled Gorgas to make healthy one of the most pestilential countries in the world, and so make possible the construction of the Panama Canal. This same discovery has been applied with equal success in other centres of infection, such as Rio de Janeiro and Vera Cruz, so that there is now a good prospect of the extermination of this disease in the western hemisphere.

$$
\begin{gathered}
\text { J. R. KEAN, } \\
\text { Lieutenant-Colonel, Medical Corps, U. S. A. }
\end{gathered}
$$

\section{BOOKS OF REFERENCE}

1. Dr. William Osler: “Equanimitas" and other addresses. Pp. 118. P. Blakiston's Son \& Co.

2. Dr. Howard A. Kelly: "Walter Reed and Yellow Fever." McClure, Phillips \& Co., New York.

3. "Major Walter Reed and the Yellow Fever Commission." A compilation prepared by authority of the surgeon-general and published as a Senate Document.

4. Major J. R. Kean: "The Scientific Work and Discoveries of the Late Major Walter Reed." Senate Doc. No. 118, 57th Congress, 2d Session.

5. Also Senate Docs. No. 10, 59th Congress, 2d Session, and No. 520, 61st Congress, 2d Session. 


\section{INDEX}

Abercrombey at Ticonderoga, 1758, 102. Adams, John, 14, 61, 99; endorses Gates, 99.

Adams, Samuel, 3; writes to Congress endorsing Gates, 99, 149.

Agnew, General, mortally wounded, 92. Allen, Colonel Ethan, 6; captured and sent to England, 23, 102.

André, Major, meets Arnold, 167; capture of, 168; death of, 169.

Anspach regiment sent by transports feared desertion, 141.

Arbuthnot, Admiral, sails for Newport, 173; with Clinton at Charleston, 208.

Arnold, Benedict, 21, 22; plans to invade Canada, 22; arrives at Quebec, 24, 25 ; wounded, 26 ; might have succeeded, 27; defeated by Carleton, 54; at Ridgefield, 80; defeats St. Leger, 108; joins Gates, 115; attacks Fraser, 116; in battle without command, 124; compared to Lee, 145; gets command at West Point, 166; meets André, 167; escapes to British ship, 168; subsequent career of, 169; sent South to reinforce Cornwallis, 227.

Ashe defeated at Briar Creek and courtmartialled, 195.

Augusta, siege of, 249.

Balcarras, Earl, at Bemis' Heights, 124. Barren Hill, skirmish, 140.

Baume, Lieutenant-Colonel, at Bennington, 110; warns Burgoyne, 111; death of, 113

Baxter, Colonel, 58; mortally wounded, 59.

Beaufort, action at, 193.

Bennington, battle of, 113.

Boston, besieged, 3 ; garrison of, 4 ; works completed, 5; evacuation of, 19.

Boyd, Colonel, at Kettle Creek, 194.

Brandywine, battle of, 85 .

Brant with St. Leger, 107.

Breyman, Lieutenant-Colonel, at Bennington, 112-113; death of, 124.

Briar Creek, battle of, 195.

British army, 139, 163.

British fleet, arrival at New York, 33

British plans for dividing the Colonies, 182.

Brown, Colonel, raids Burgoyne's communications, 119.

Browne, Lieutenant-Colonel, defends Augusta, 250.
Brunswick Dragoons at Bennington, 110.

Brunswick, Duke of, 28.

Bunker Hill, Gage's plan of attack, 7; Howe's formation for assault, 9; American retreat, 10.

Burgoyne, in command of reinforcements, 26; resented being shut up in Boston, 30; reasons for the loss of his army, 31 ; selected to command two expeditions from Canada, 77; his plan to reach Albany, 78; his force, 96: arrives at Quebec, 100; advances from Crown Point, 103; captures Ticonderoga and pursues Long up the lake, 104, 106: takes Fort Edward, 109; starts for Bennington, 110; position precariout, 114; at Freeman's Farm, 116; at Bemis' Heights, 123; negotiates for surrender, 125; signs terms, 127; goes to England on parole, 130, 139.

Burnside's report, 312-313; not adopted, 314.

Burr, Aaron, 23.

Cadwalader, Colonel John, with Magaw at New York, 58; letter to, from Washington, 66, 67; occupies Bordentown, 69; ordered to join Washington, 70 .

Calhoun's reports, 299; not adopted, 301.

Camden, battle of, 218 .

Campbell, Captain, messenger to Burgoyne, 117; Colonel, sent to attack Fort Montgomery, 121.

Campbell, Lieutenant-Colonel Archibald, sent to Georgia, 189; at Savannah, 191; killed at Eutaw Springs, 255.

Carleton, Sir Guy, Governor of Canada, at Montreal, 22; escapes in a small boat, 23; learns of Arnold's approach, 24; at Quebec, 25; fails to attack Arnold, 26; reinforced by Burgoyne, 31; at Crown Point, 54; renders Burgoyne every assistance. 100.

Carlisle, Earl of, heads peace commission, 138.

Carrington, quartermaster-general of Greene's army, 226; meets Morgan with boats, 233, 234.

Chad's Ford, battle of, 84 .

Charleston, preparations for the defence of, 184 ; result of the victory, 188 ; 
unsuccessful attack of Prevost, 197; its siege by Clinton, 209; its surrender, 210.

Charlestown set on fire, 9.

Chew, Chief Justice, 91.

Civil War, the, 307; call for volunteers, 307; resort to conscription, 308; number of men in service, 308 ; defects of military system, 309; compared with previous wars, 310 ; disbandment of the volunteers, 311.

Clarke, Colonel, defeats Dunlap, 214; at siege of Augusta, 250.

Clary, Lieutenant-Colonel, 49.

Clinton, Fort, captured, 121.

Clinton, General George, 49; hastens to the relief of his brother, 121-138.

Clinton, General James, 61; commander Forts Clinton and Montgomery, 121.

Clinton, Sir Henry, at Bunker Hill, 10; failure at Charleston, 31 ; arrives at New York, 33; attacks Sullivan on Long Island, 38; lands at Kip's Bay, 46; sent to Newport, 62; notifies Burgoyne of intention to attack Fort Montgomery, 117; his message to Burgoyne, 118; moves up Hudson, 120; fails Burgoyne, 122; in supreme command, 134; attempts to capture Lafayette, 140; evacuates Philadelphia, 141; at Monmouth, 144; escapes, 147; arrives at Newport, 154 ; captures Stony Point, 156: reoccupies Stony Point, 159; sends marauding expedition up the Chesapeake, 161; corresponds with Arnold, 167; appeals for Andre, 169; sails for Newport, 173; returns to New York, 174, 176; at Charleston, 185; his expeditlon South, 206; lands near Charleston, 207; sends reinforcements South, 223; sends 7,500 men to Cornwallis, 261; instructions to Cornwallis, 266; goes to relieve Cornwallis, 273; superseded by Carleton, 278.

Continental army, 17; movement to New York, 31-54, 162; ineffective plans for recruiting, 175; origin of, 288.

Continental Congress, appoints Washington commander-in-chief, 13, 75; adjourns to York, $\mathrm{Pa} ., 89$; sends committee to Valley Forge, 134; ineffective resolutions of, 289; military powers of, 295.

Conway, Cabal, 134; wounded in a duel, makes abject apology to Washington, 135.

Conway's brigade, 90.

Cornwallis, reinforces Clinton at Charleston, 31; arrives at New York, 33; sent to Flatbush, 35; at the Cortelyou house, 39; lands at Kip's
Bay, 46; at Harlem Helghts, 49; at Fort George, 58; at Fort Lee, 59, 60; captures Lee, 65; his attempt to turn Washington's flank, 66. rejoins his command, 70 ; marches toward Princeton, 71, 72; in battle of the Brandywine, $84 \mathrm{et}$ seq.; hurrying with reinforcements, 92; attacks Fort Mercer, 94, 163; with seven regiments at Cape Fear River, 184; goes South with Clinton, 206; defeats Gates at Camden, 219; retreats to South Carolina after King's Mountain, 224; burns his baggage to pursue Morgan, 232; gives up the chase, 235; he defeats Green at Guilford, 240; retreats to Wilmington, 242; his perplexity at Wilmington, 259; arrives at Yorktown, 267; surrender, 275; returns to England, 278.

Cowpens, battle of the, 229.

Crown Point, capture of, 6 .

Cruger, Lieutenant-Colonel, sent to Georgia, 189; commands defence of Ninety-Six, 250.

Cuba, occupation of, 338.

Dearborn, Henry, 23.

De Grasse, announces his co-operation, 270; arrives at Cape Henry, 272; his naval battle with the English fleet, 273.

De Kalb, Baron, sent South by Washington, 214; mortally wounded at Camden, 218.

De Lancey, Colonel, sent to Georgia, 189. Delaware, Washington crosses the, 66; forts destroyed, 93.

Dillon, Count, at Savannah, 203.

Donop, General, lands at Kip's Bay, 46; at Harlem Helghts, 49; on the Delaware, 66; retreats to Amboy, 69; death of, 94 .

Dorchester Heights seized, 18.

Duer, William, 64.

Duportail stationed on coast to communicate with d'Estaing, 171.

Edward, Fort, 109.

Estaing, Comte d', arrives with French fleet, 149; fails to attack, 150; sails for Newport, 150; fails to land his troops, 151; abandons allies at Newport, 152; sails for Martinique, 154; movements of, 171; returns with three expeditlons, 200; after fasco at Savannah, sails for France, 205.

Eutaw Springs, battle of, 255.

Ewing, Colonel, 68.

Fellow's brigade at Saratoga, 125.

Ferguson killed at King's Mountain, 224. Fleury receives medal from Congress, 159. 
Florida war, 301.

Francis killed, 104.

Fraser's brigade, at Ticonderoga, 103; at battle of Hubbardton, 104 ; mortally wounded, 124.

Freeman's Farm, battle of, 116.

French alliance, 132.

Gadsden, Colonel, at Charleston, 185.

Gage, Major-General Thomas, commander-in-chief at Boston, 4; issues insulting proclamation, 7; assaults American works in front, 8 ; recalled in disgrace, 11.

Gansevoort, Colonel, sent to Fort Stanwix, 106, 108.

Gates, Horatio, appointed adjutant-general, 16; called in council, 17 ; at Ticonderoga, 54; joins Washington, 65; relations with Schuyler, 97; elected to command the Northern army, 99; his strength at surrender of Burgoyne, 106; relieves Schuyler, 114; refuses to reinforce Arnold, 116; jealous of Arnold, 118; not on field at Bemis' Heights, 124; surrounds Burgoyne, 125; grants armistice until sunset, 128, 137; retires from army, 166; sent South by Congress to command army, 215; defeated at Camden, 218.

George III, arranges to buy soldiers for cash, 28; endorses Burgoyne's plan, 78; plan that the king disliked, 131 .

Georgetown, capture of, 253.

Georgia, conquest of, 192.

Gerard, guest of d'Estaing, 154, 171.

Germain, Lord George, 76; had failed to give Howe instructions, 119; incompetence of, 264.

Germantown, battle of, 90; panic of, 92.

Gist, Major, captured, 39.

Glover, Colonel John, regiment of Marblehead fishermen, 42, 43; his regiment to man the boats at the crossing of the Delaware, 67; brigade sent to Schuyler, 105; at Newport, 153.

Granby, Fort, capture of, 249.

Grant, Major-General, takes over Cornwallis's command, 66; rallies his troops, 92; at Barren Hill, 140.

Graves, Admiral, 4; arrives with fleet, 173.

Great Bridge, battle of, 183.

Greene, Christopher, 23; gallant defence of Fort Mifflin, 94; in command of Rhode Island negroes at Newport, 153.

Greene, General Nathanael, appointed brigadier-general, 15; a great soldier, 16; in council of war, 17; at Boston, 19; ordered to Brooklyn Heights, 32; at New York, 34, 35; illness at the battle of Long Island,
41; advocates evacuation of New York, 45; his division posted after retreat to Harlem Heights, 47; at battle of Harlem Heights, 48; in command of troops at Forts Lee and Washington, 52, 54; reports the passage of British ships up the river, 55; crosses river to Fort Washington with Washington, Putnam and Mercer, 57; brings off the garrison of Fort Lee, 60; on march to Trenton, 67; in the attack on Trenton, 68 ; advises pushing on to Princeton, 69; gets one of the five new divisions, 76; selects position at Middlebrook, 80; in pursuit of Howe with three brigades, 81 ; on reconnoissance with Washington and Lafayette, 83 ; his batteries at Brandywine, 85; halts British advance, 86 ; nearing the battle of Germantown, 90; fighting his way along Lime-kiln road, 91; appointed quartermaster-general, 136; organization at Valley Forge, 140; at Monmouth, 146; at Newport, 153; his loss at battle of Springfield, 165; resigns as quartermastergeneral, 166; president of Andre court-martial, 169; appointed to command Southern army, 220; his successful retreat, 234 ; receives reinforcements, 236; marches to South Carolina, 244; abandons siege of Fort Ninety-Six, 251; retreats from Eutaw Springs, 256.

Grey, General, attacks Wayne, 88, 140. Gridley, Colonel Richard, chief engineer at Boston, 5; sends guns to Cambridge from Ticonderoga, 6; builds square redoubt at Breed's Hill, 7; amazes Howe by night work on Dorchester Heights, 18.

Guilford, battle of, 238 .

Hale, Nathan, absent at his own request, 47.

Hamilton, Alexander, 52; nearing his twentieth birthday, 68; sent to welcome Comte d'Estaing, 149; sent to capture Arnold, 168, stationed on Jersey coast to meet d'Estaing, 171; leads the assault at Yorktown, 274.

Hamilton, General, in council of war with Burgoyne, 125.

Hancock, John, 3; at head of 7,000 New England militia, 150.

Hand, Colonel, at Trenton, 68; his regiment at Princeton, 71.

Harlem Heights, battle of, 49 .

Haslet, Colonel, 52; killed at Princeton, 71.

Heath, William, appointed brigadiergeneral, 14; in council of war, 17; stationed with Spencer and Stirling, 
32 ; commands one of the five divisions, 34 ; after reorganization commands one of the three divisions, 44; commands Greene's division during his illness, 47; arrives at White Plains, 52; head-quarters at Peekskill, 54; might have been captured, 61; ordered to Morristown, 69; goes into winter quarters, 72.

Henry, Patrick, Washington's appea Ito, as Governor of Virginia, 138; his eloquence fires the Southern Colonies, 183.

Herkimer, General, 106; at battle of Oriskany, 107; death of, 108.

Herrick, Colonel, at Bennington, 113.

Hesse-Cassel, Landgrave of, 28.

Hessians, engagement with, by England, 28; at battle of Long Island with Cornwallis, 35; loss at White Plains, 53; they attack Fort Washington, 58; at Trenton, 67; they advance to Chad's Ford, 84; at battle of Brandywine, 85.

Hinman, Colonel, 22.

Hobkirk's Hill, battle of, 246.

Hopkins, Commodore Ezek, 33.

Howe, Lord, 93; at Sandy Hook to meet French fleet, 149; at Newport, 154.

Howe, Major-General Robert, quells mutiny of New Jersey line, 177, 189; at Savannah, 190; tried by courtmartial, 192.

Howe, Sir William, sent out from England, 5; in command at Bunker Hill, 8; leaves Boston, 20; arrives at New York, 33; at battle of Long lsland, 37; lands in New York, 46; flanking movement through Westchester, 51; at battle of White Plains, 52; sends Cornwallis in pursuit of Washington, 59; captures Fort Washington, 60; goes into winter quarters, 62 ; withdraws from New Jersey, 72; sails for Chesapeake, 82 ; at Chad's Ford, 82 ; at battle of Brandywine, 85; captures Philadel phia, 88; attacks Washington, 93; returns to Philadel phia, 95; resignation of, 134; sails for England, 141.

Hubbardton, battle of, 104 .

Hutchinson, Colonel, 27; Fort, 43.

Jackson's opinions, 303.

Jamestown, battle of, 263.

Jay, John, 64.

Johnson, Sir John, 97, 107.

Jones, Brigadier-General, 4.

Kettle Creek engagement, 194.

King's Mountain, battle of, 223 .

Kip's Bay, British land at, 46.

Knowlton, Colonel Thomas, ordered to reconnoitre with his "Rangers," 47 ; ordered to get in rear of the British, 48; death of, 49 .

Knox, Henry, drags cannon through the snow from Ticonderoga, 18; guns placed under direction of, 32; his guns outclassed by Iritish fleet, 33; his letter of December 28, 67; directing the artillery at Trenton, 68.

Knyphausen, Lieutenant-General, 53; his attack at Fort Washington, 58; Magaw surrenders to, 59; sustained threc-fourths of the losses at Fort Washington, 60; at Brandywine, 85; Wayne unable to resist his advance, 87 ; in charge of Clinton's baggage, 143; at Monmouth, 144; expeditions into Jersey, 163; left in command in New York, 206.

Kosciusko, fortifies Bemis' Helghts, 115; engineer of Greene's Southern army, 226; sent to throw up trenches, 234; opens first parallel at Ninety-Six, 250.

Lafayette, Marquis de, arrival of, 83; wounded, 86; commands a division, 140; sent to Providence with two brigades, 150; sails for France, 154; member of André court-martial, 169; returns from France, 171; sent to confer with Rochambeau, 172; had gathered a few hundred militia, 261; retreats from Richmond before Cornwallis, 262; returns to France, 278.

Laurens, Colonel John, aide-de-camp. sent to recelve Comte d'Estaing, 149; sent to France to raise money, 178.

Learned's brigades at Saratoga, 125.

Lee, Charles, appointed major-general, 14 ; in council of war, 17; sent to New York, 31; reports situation in New York, 32; reaches White Plains, 52; at North Castle with 5,000 men, 54; might have been prevented from crossing Hudson, 61; Washington gives him orders in writing, 63; his dilatory march, 64; capture, 65; a prisoner in Howe's hands, 77; gives traitorous Information to Howe, 78; his disgrace at Monmouth, 145; his courtmartial, 148; sent to Charlestor, 185.

Lee, Major Henry, captures Paulus Hook, 159; sent to defend Vauxhall bridge, 165; statloned on Jersey coast to meet d'Estaing, 171; captures Fort Granby, 249; hastens to join Greene at Ninety-Six, 250

Leitch, Major, wounded, 49.

Leslie, General, 52; sent South to relnforce Cornwallis, 225.

Lincoln, General, goes into winter quar- 
ters at Morristown, 72; commands one of the five divisions of new troops, 76; sent by Washington to organize the New England militia, 111; brings troops to Gates's camp, 119; at Beaufort, 193; takes the offensive, 194; defeated at Stono Ferry, 198; joins d'Estaing at Savannah, 201; raises siege, 205; defeated at Charleston, 210.

Livingston, Colonel James, 23.

Long retreats before Burgoyne, 105.

Long Island, battle of, 35; Howe's plan of battle, 37; arrival of Washington, 39 ; responsibility for the defeat, 40; withdrawal from, 42.

McDougall, General, raises the first New York regiment, 43; retreats bringing off the guns at White Plains, 53; with Greene at Germantown, 90; fails to attack Verplanck's Point, 157.

Magaw, Colonel Robert, commander at Fort Washington, 56; commands three regiments, 58; opposes Howe's fourth attack, 59.

Mahan, Captain, criticises Comte d'Estaing, 150.

Marion, on lower Pedee, 225; was hiding in the Pedee swamps, 244; captures Fort Motte, 248; captures Georgetown, 253.

Marjoribanks, Major, sortie at Eutaw Springs, 256.

Mawhood attacks Mercer's brigade, 70.

Maxwell's brigade, 92.

Mercer, Fort, 94

Mercer, General, reported to have arrived at Long Island as the retreat began, 43; offered to stay at Fort Washington, 57; death of, 71 .

Mexican War, 306.

Mifflin, Fort, 94.

Mifflin, Thomas, quartermaster-general, 16; left to man the works on retreat from Long Island, 43; withdrawn under cover of fog, 44 ; sent to Philadelphia to take charge of the stores, 63; militia raised by his exertions at Philadelphia, 69; ordered to join Washington after Trenton, 70; in Conway Cabal, resigns from army. 135.

Military policy, origin of, 284; necessity of a definite one, 336 .

Militia, popularity of, in England, 287; popularity of, in American Colonies, 288; act, 296; refusal to furnish, 1814,298 ; act of $1903,326$.

Mischianza, the, 141.

Monckton, Colonel, killed, 146.

Moncrieff, Colonel, engineer at siege of Charleston, 209.

Monmouth, battle of, 144 .
Monroe, Lieutenant James, 68.

Montcalm at Ticonderoga in 1758, 102.

Montgomery, Fort, captured, 121.

Montgomery, Richard, appointed brigadier-general, 14; captures Montreal, 23; joins Arnold, 24; death of, 25.

Montreal, capture of, 23.

Moore, General, in command at battle of Moore's Bridge, 183.

Moore's Bridge, battle at, 183.

Morgan, ranger, defeats Carleton, 230: retreats to the Catawba, 231.

Morgan's riflemen, sent to Schuyler, 105; attack Fraser, 116; at battle of Bemis' Heights, 123; in pursuit of Burgoyne, 125.

Morris House, Washington gallops from, 46; the $42 \mathrm{~d}$ Highlanders attack, 59.

Moultrie, Fort, surrenders, 210.

Moultrie, 64; in defence of Charleston, 185; won the battle at Sullivan's Island, 186; records his opinion, 202.

Muhlenberg, 86; at Stony Point, 157.

Murray, Mrs., detains Howe.

Musgrave, Colonel, places five companies in the Chew house, 90.

Nash, General, mortally wounded at Germantown, 92.

New Jersey line mutineers, 177.

New London massacre, 170.

Newport, attack on, 150; evacuated by the British, 174.

New York, defence of, 31; fortifications of, 33; disposition of troops, 34 .

Nicholls, Colonel, at Bennington, 113.

Ninety-Six, siege of, 250; evacuated, 252.

Nixon's brigade sent to Schuyler, 105.

O'Hara at Guilford, 241.

Orangeburg, capture of, 249.

Paoli massacre, 88.

Parker, Admiral, 31; arrives at Charleston, 185; defeated, withdraws, 187.

Parker, Commodore Hyde, sent to Georgia, 189.

Paulus Hook, capture, 160.

Peace Commission, 138.

Pell's Point, 51.

Pennsylvania line, mutiny of, 176.

Penobscot expedition, 161.

Percy, Earl, his brigade in garrison of Boston, 4; to attack Dorchester Heights, 19; left in New York, 51; Howe reinforced by two brigades of his division, 53; attacks Washington Heights, 58.

Philippine insurrection, 320.

Phillips's brigade seizes Mount Hope, 103; Phillips takes possession of 
Fort George, 109; in council of war with Burgoyne, 125.

Pickens, Colonel Andrew, at Kettle Creek, 194; on familiar ground, 244; hastens to join Greene at NinetySix, 250; returns to his old recruiting-ground, 253.

Pigott, Brigadier-General, 4; attacks at Lexington, 10; at Newport, 153.

Pomeroy, Seth, 8; appointed brigadiergeneral, 14.

Poor, Colonel, 71; after Bennington, 115; at Bemis' Heights, 123; his brigade helps to surround Burgoyne, 125.

Potter, Colonel, killed, 71.

Prescott, Colonel, fortifies Bunker Hill, 7; completes his breastworks at Bunker Hill, 8; retains the command, 9 .

Preston, Major, commanding at St. John, 23.

Prevost, Lieutenant-Colonel, at Briar Creek, 195.

Prevost, General, at Savannah, 190; summons Charleston to surrender, 196; withdraws, 197; retires to Savannah, 199.

Princeton, battle of, 70 .

Pulaski, 92; at Charleston, 197; mortal$1 y$ wounded at Savannah, 204

Putnam, Israel, appointed major-general, 14; called in council of war, 17; given one of the five divisions at New York, 34; takes command on Long Island, 35; failure as commanding general, 40; Washington's letter to, 41; commands one of three divisions, 44; in the retreat from New York, 46; his division posted on the heights, 47; meets Washington on the retreat, 48 ; in action at Harlem Heights, 49; leaves White Plains with Washington, 57; sent to fortify Philadelphia, 63; at Peekskill, 76; reports from, 82 ; out-generalled by Clinton, 120; retreats up the river, 122; opposition to Washington, 137.

Pyle, colonel of tories, defeated, 236.

Quebec, siege of, 25; retreat from, 26.

Rall, Colonel, attacks with Knyphausen, 58; in command at Trenton, 66; rudely awakened, 67 ; tries to form his troops, 68; his death, 69 .

Rawdon, Lord, at Charleston, 210; defeats Greene at Hobkirk's Hill, 246; evacuates Camden, 248; comes to the relief of Fort Ninety-Six, 250; captured at sea by Count de Grasse, 252.

Rawlings' regiment, 58,60 .

Reed, Adjutant-General Joseph, had been with Knowlton, 48; in action at Washington Heights, 49; wonders if Washington was such a great man as he had been thought, 64 .

Revolution, nearly exhausted, 174; waste and extravagance of, 291.

Riedesel, at battle of Hubbardton, 104; anxious to mount Duke of Brunswick's dragoons, 110; council of war with Burgoyne, 125.

Rochambeau, 168; arrives with six French regiments, 172 ; at Hartford, 174.

Root, Elihu, as Secretary of War, 320; his projects, 321; his plan for army, 329.

St. Clair, selected for service at Ticonderoga, 99; his force, 100; garrison of, 102; evacuates Ticonderoga, 103; watches Castleton, 104; sent by Washington to stop Pennsylvania mutineers, 177.

St. Leger, commences expedition from Oswego, 96; advancing on Stanwix, 100 ; his papers captured, 107; defeated by Arnold, 108.

Saratoga, surrender of Burgoyne, 125. controversy about terms at, 128.

Savannah, capture of, 191; defence of, 201 ; siege of, 202.

Schuyler, Fort, siege of, 108.

Schuyler, Philip, appointed major-general, 14 ; to command Northern army, 22; sick with fever, 23; Arnold's letter to, delivered to Carleton, 24; Washington calls on him for troops, 64; reports from, led Washington to think Howe intended to move up the Hudson, 82; his difference with Gates, 97; reprimanded by Congress, 98, 100; reinforcements for, 105; calls council of war, 108; retreats to Stillwater, 109.

Scott, Captain, third message to Burgoyne, 118.

Second war with Great Britain, 298.

Skenesborough, battle of, 104 .

Smallwood, General, 90.

Smith, Colonel, death of, at Fort Mifflin, 94.

South Carolina, defence of, 193.

Spain, war with, 316; mistakes of Civil War not repeated, 317 ; prompt organization, 318.

Spencer, Joseph, appointed brigadier-general, 15; called in council, 17; stationed just outside New York, 32; commands one of the five original divisions, 34 ; after reorganization commands one of the three divisions, 44; his division at about 147th St., 47; along the hilis behind the Bronx, 51 .

Springfield, battle of, 164.

Standing army, hatred of, 286; opposition to, 291; ibid., 296. 
Stark, General John, at Bennington, refuses to obey orders, 111 ; receives thanks of Congress, 112.

Stephen, General, in command of division, 76; his division fires into Wagner's division, 91; court-martialled and dismissed, 92.

Steuben, Baron, appointed inspectorgeneral, 137; organlzation prepared by, 175 ; second in command to Greene in the Southern army, 220; on the James, 261.

Stewart, with Wayne at Stony Point, receives medal from Congress, 159.

Stewart, Colonel, of the Guards, killed at Guilford, 241.

Stewart, Lieutenant-Colonel, reinforces Rawdon, 252; commanded British force at Eutaw Springs, 254.

Stirling, General Lord, stationed just outside New York, 32; his herolc attack, 38; capture of, 39; fought splendidly at Long Island, 40; his division reaches White Plains, 52; gets one of the five original divisions; 76; driven back by Howe, 81 ; sent to cross the Hudson at Peekskill, 82, made the most stubborn resistance at Brandywine, 86; his division formed the reserve at battle of Germantown, 90; gets one of the four divisions at Valley Forge, 140; at Monmouth, 161.

Stono Ferry, battle of, 198.

Stony Point, capture of, 156; recapture, 157; evacuation, 159.

Sullivan, John, appointed brigadier-general, 14; in council of war, 17; to attack Boston Neck, 19; ordered to supersede Thomas, 26; not equal to an enterprise like expedition to Quebec, 27; driven back at Quebec, 29; had brought back his regiments from Ticonderoga, 34; sent to take Greene's place, 35 ; captured, 38 ; unjust to hold him responsible for the battle of Long Island, 40; arrives at White Plains, 52; guarding fords of the Delaware, $66 ; 68,70,71$, $76,80,82,85,86,90,91$; at Providence, 150 .

Sullivan's Island, battle at, 186.

Sumter, 244; captures Orangeburg, 249, 253.

Tarleton, with Clinton at Charleston, 209; his cavalry at Camden, 218.

Taylor, Sergeant, hung as spy, 117.

Ternay, de, arrival with second French fleet, 172; at Hartford, 174.

Thomas, John, appointed brigadier-general, 14; called in council, 17; Occupied Dorchester Heights, 18; re- inforcement of 2,000 men ordered for, 19; given command at Quebec and dies of small-pox, 26; not equal to the conquest of Quebec, 27.

Thompson, Colonel, at Sullivan's Island, 185.

Throg's Neck, 51.

Ticonderoga, captured by Ethan Allen, 6; topography of, 100; previous operations at, 102; evacuation of, 103.

Tompkins, Daniel D., 145.

Trenton, battle of, 67 .

Trumbull, Jonathan, 21, 138.

Tryon, Governor, raid into Connectlcut. 80.

United States army, origin, 297; growth of, 305; reorganization of, 311,322 ; general staff, 324.

Upton's "Military Policy," 313.

Valley Forge, 132.

Van Buren's opinions, 303.

Varnum's Rhode Island regiments at Newport, 153.

Vaughan attacks Fort Clinton, 121.

Vergennes's opinion of Laurens's diplomacy, 178.

War, possibility of, 333; inadequate preparation for, 335 .

Ward, Artemas, appointed commanderin-chief, 4; his regiments construct field works, 5: sends Prescott reinforcements, 8; created major-general, 14; in council of war, 17; left in command in Boston when Washington went to New York, 20.

Warner's regiment at battle of Hubbardton, 104; Warner, 113.

Warren, Joseph, President of Provincial Congress, 8; death of, 10.

Washington, appointed commander-Inchief, 13; arrives at Cambridge, 16, reaches New York, 33; arrival at battle of Long Island, 39; retreat from Long Island, 43; disposition of troops in New York, 44; tries to rally retreating brigades at Kip's Bay, 46; arrives on Harlem Heights, 47, 48; disappointed in Fort Washington, 51; White Plains, 52; retreats to North Castle, 53, 60; retreats to the Delaware, 62,64 ; he crosses the Delaware, 66; at Trenton, 67; recrosses the Delaware, 70 ; arrives at Morristown, 72; raising new army, 75; moves to Middlebrook, 80; marches south through Philadelphia, 83; returns to Chad's Ford, 84; fights battle at Brandywine, 86 .

Washington, General, at Germantown, 
90; at Valley Forge, 133; writes two letters to Congress, 134; brings Continentals to Valley Forge, 137; leaves Valley Forge, 142; mutiny with Lee at Monmouth, 145; goes to White Plains, 148; in camp at Middlebrook, 155; retires to winter quarters at Morristown, 162; Washington approves Andrés sentence, 169; threatens New York to draw Clinton from Newport, 173; goes to Hartford, 174; sends Greene to command Southern army, 220; he meets Rochambeau at Hartford, 267; starts for Yorktown, 270; boldness of, 271; strategy compared to Napoleon's, 272; jolns Lafayette, 273; returns to New York, 278.

Washington, George, his ability as a soldier, 279; dictator, 290; his opin. ions, 292.

Washington, Captain William, 68; with Greene's army South, 226; came up with his cavalry, 229; at Guilford Court House, 238; wounded and captured at Eutaw Springs, 255.
Washington, Fort, to be completed, 45, 50 ; loss of, 57; results of loss, 60 . Watson, Fort, capture of, 245.

Wayne, Anthony, 86; at Brandywine, 87; at Germantown, 90; his division fired into, 91 ; gets one of the four divisions formed at Valley Forge, 140 ; at Monmouth, 146; at Stony Point, 157; mutiny of his division, 176; hangs three emissaries from Clinton, 177; at York, Pa., 261; joins Lafayette, 263.

Weedon, Colonel, with Sullivan, 86.

Wharton, Thomas, governor of Pennsylvania, 138.

White Plains, battle of, 52.

Willett, Lieutenant-Colonel, at Fort Stanwix, 106; ordered to make a sortie at Oriskany, 107; sent to ask aid from Schuyler, 108.

Wooster, David, appointed brigadiergeneral, 15; arrival at Quebec, 26, 27 ; mortally wounded, 80 .

Yellow-fever, conquest of, 338.

Yorktown, siege of, 274; surrender of, 275. 



\section{HOME USE \\ CIRCULATION DEPARTMENT MAIN LIBRARY}

This book is due on the last date stamped below. 1-month loans may be renewed by calling 642-3405. 6-month loans may be recharged by bringing books to Circulation Desk.

Renewals and recharges may be made 4 days prior to due date.

ALL BOOKS ARE SUBJECT TO RECALL 7 DAYS AFTER DATE CHECKED OUT.

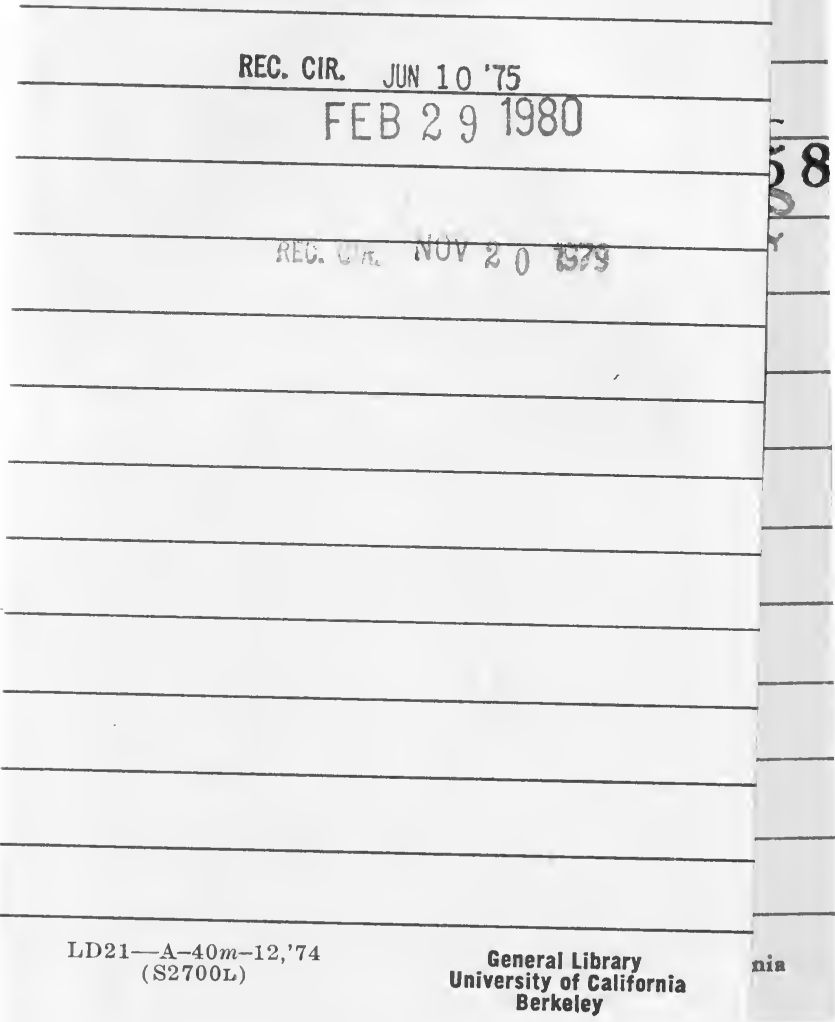


